\title{
Estimación de la efectividad de las pruebas histopatológicas, ELISA y de PCR para el diagnóstico rápido de la tuberculosis y paratuberculosis bovina en mataderos del Estado de Nayarit (México)
}

\section{MARIA TERESA CAMARENA HERRERA}
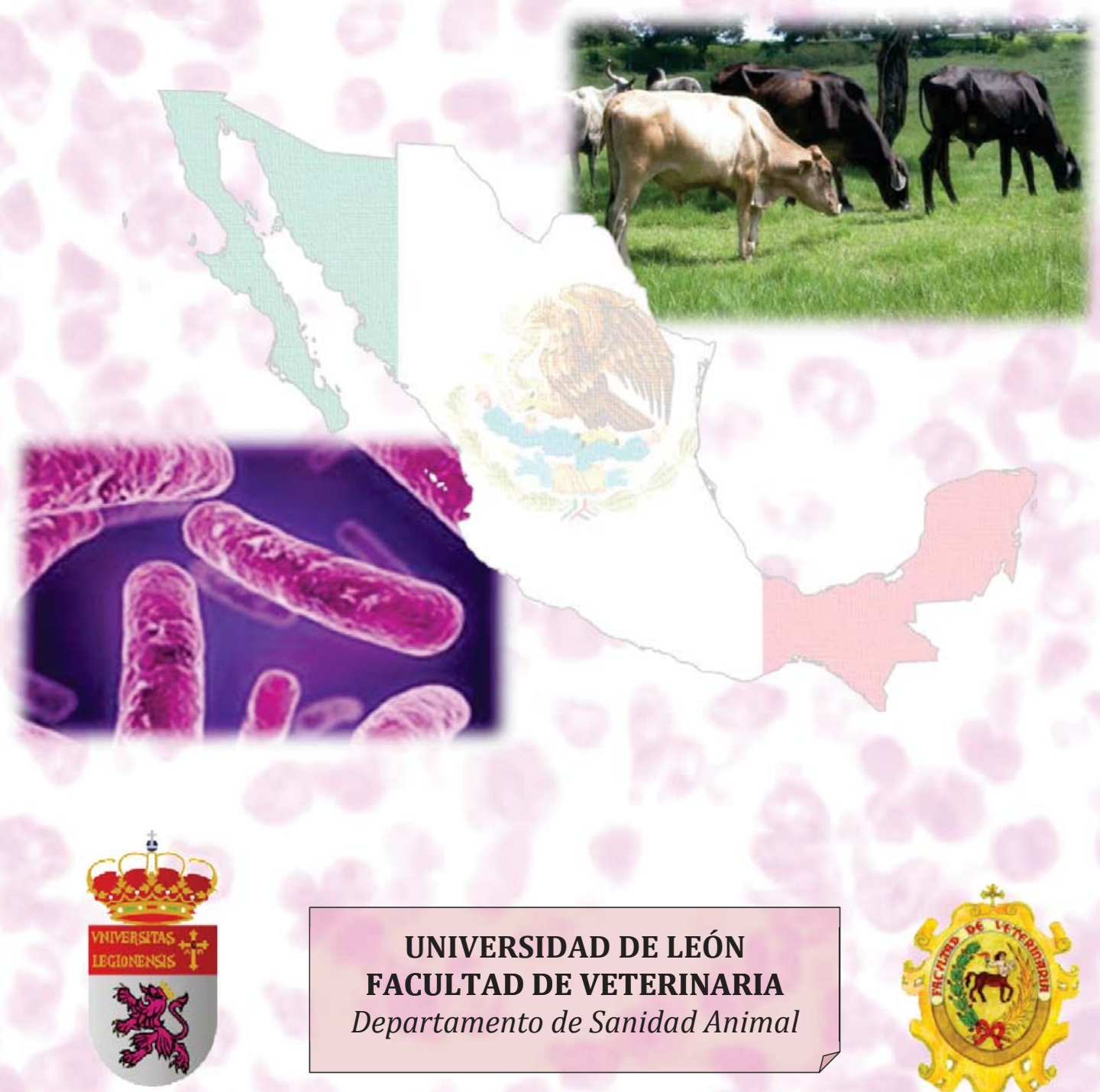

UNIVERSIDAD DE LEÓN

FACULTAD DE VETERINARIA

Departamento de Sanidad Animal 


\title{
UNIVERSIDAD DE LEÓN \\ FACULTAD DE VETERINARIA \\ DEPARTAMENTO DE SANIDAD ANIMAL
}

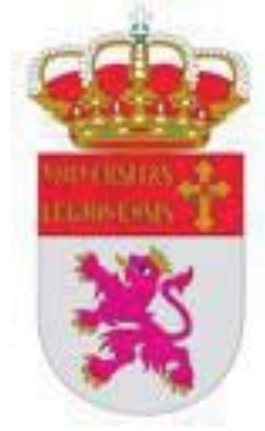

\begin{abstract}
"Estimación de la efectividad de las pruebas histopatológicas, ELISA y de PCR para el diagnóstico rápido de la tuberculosis y paratuberculosis bovina en mataderos del Estado de Nayarit, México.
\end{abstract}

\author{
MEMORIA PARA OPTAR AL GRADO DE DOCTOR \\ PRESENTADA POR \\ MARÍA TERESA CAMARENA HERRERA
}

Bajo la dirección de los Doctores

Juan Francisco García Marín

Valentín Pérez Pérez

María del Carmen Ferreras Estrada

LEÓN, 2014 


\section{INFORME DEL DIRECTOR DE LA TESIS}

El Dr. D. Juan Francisco García Marín, Valentín Pérez Pérez y Ma. Del Carmen Ferreras Estrada como Directores de la Tesis Doctoral titulada "Estimación de la efectividad de las pruebas histopatológicas, ELISA y de PCR para el diagnóstico rápido de tuberculosis y paratuberculosis bovina en mataderos del Estado de Nayarit, México" realizada por D. María Teresa Camarena Herrera en el programa de doctorado Producción y Sanidad Ovina, informa favorablemente el depósito de la misma, dado que reúne las condiciones necesarias para su defensa.

Lo que firmo, en León a 14 de Marzo de 2014

Fdo.: J.F. García Marín

V. Pérez Pérez

M.C. Ferreras Estrada 


\section{ADMISIÓN A TRÁMITE DE LA TESIS DOCTORAL}

El órgano responsable del programa de doctorado Producción y Sanidad Ovina en su reunión celebrada el día 17 de Marzo de 2014 ha acordado dar su conformidad a la admisión a trámite de lectura de la Tesis Doctoral titulada "Estimación de la efectividad de las pruebas histopatológicas, ELISA y de PCR para el diagnóstico rápido de tuberculosis y paratuberculosis bovina en mataderos del Estado de Nayarit, México", dirigida por los Dres. D. Juan Francisco García Marín, Valentín Pérez Pérez y la Dra. D. Ma. Del Carmen Ferreras Estrada, elaborada por D. María Teresa Camarena Herrera y cuyo título en inglés es el siguiente "Assessment of the eficiency of histopatological methods, indirect ELISA and PCR for the rapid diagnosis in bovines slaughtered in the State of Nayarit, México".

Lo que firmo, en León a 17 de Marzo de 2014.

El Secretario,

Fdo.: Dr. D. Juan M. Fregeneda Grandes

ํo $\mathrm{B}^{\circ}$

El Director del Departamento/

Presidente de la Comisión Académica,

Fdo.: Dr. D. César B. Gutiérrez Martín 
AGRADECIMIENTOS 
Para la realización de esta tesis necesite la ayuda de muchas personas a las cuales quisiera expresar mi más sincero agradecimiento.

Especialmente quiero agradecer a mis directores de tesis, Dr. D. Juan Francisco García Marín, Dra. Dña. María del Carmen Ferreras Estrada y Dr. D. Valentín Pérez Pérez, por la confianza en mí, porque siempre estuvieron dispuestos a brindarme su ayuda en todo momento, por sus enseñanzas y sobre todo por la paciencia que tuvieron conmigo. Sin ellos esta tesis no hubiera sido posible, y aun con el paso del tiempo su recuerdo y ejemplo siempre vivirá en mi mente y corazón, les estaré eternamente agradecida "Mil Gracias".

Gracias a Sonia y Silvia por transmitirme sus conocimientos en las diferentes técnicas de diagnóstico, por su ayuda desinteresada, pero sobre todo por los buenos ratos pasados y lo más importante por su amistad.

A Glory por todos esos días en el café que se convertían en los mejores momentos del día, por la confianza que tuvo en mi para compartirme su historia, por sus sabios consejos y sobre todo porque cuando más necesite un hombro para llorar o de un simple abrazo ella siempre tuvo tiempo de apoyarme, te quiero y nuestra amistad perdurara aun en la distancia.

Fueron muchos años desde el inicio de esta tesis en los cuales muchas personas se hicieron importantes e inolvidables en mi vida, como Daphne, Bettit, María, Laetitia, Paco, Cristian y Adelino, que estuvieron siempre cuando más los necesitaba, apoyándome y dándome ánimos para seguir con este sueño que por fin hoy ya es una realidad.

A mi hermana Gaby que siempre estuvo al pendiente de mí, por sus infinitas llamadas y mensajes para animarme, porque con su buena vibra es imposible sentirse triste y porque a pesar de no verla mucho, siempre está en mi mente y en mi corazón.

A Edwin y Fidelina por convertirse en parte de mi familia, porque gracias a ellos mis días fueron menos grises haciéndome sentir querida. 
A Donal y Andy que con su cariño y apoyo conocí el verdadero significado de la amistad, porque su compañía convertía mis días nublados en maravillosos y su buena vibra siempre me contagio de positividad y alegría.

También mi agradecimiento y reconocimiento a los Dres. Ma. José, Claudia, Jorge por regalarme una sonrisa y por su ejemplo de responsabilidad. A Miguel y Mikel por su ayuda desinteresada, a Pablo, Elena y Marcos por hacer de este departamento el mejor.

A la Universidad Autónoma de Nayarit, México por colaborar económicamente con mis estudios para hacer de mí una mejor persona.

A los veterinarios y trabajadores de los mataderos en los que recolecte las muestras y en especial al matadero de Tepic, donde no solo encontré gente que me apoyara más allá de sus obligaciones, sino que además hicieron que las horas fueran amenas y rápidas.

Durante muchos años estuve pensando en los nombres de las personas a las que agradecería y estoy segura que con la emoción de haber culminado mi tesis me olvide de muchas personas, así que anticipadamente pido perdón, y les agradezco de corazón, Mil Gracias. 
DEDICATORIAS 
Después de tanto tiempo que ha pasado, hoy me parece mentira que al fin concluí una etapa más de mi vida, a pesar de tantos momentos de soledad, angustia y desesperación, hoy me alegro de haberlo logrado, pero esto sin duda alguna no hubiera sido posible sin el apoyo de cuatro personas, las más importantes en mi vida y por este y muchos motivos, quiero dedicarles esta tesis.

En primer lugar a mis dos hijos, Diana Carolina y Oscar Gabriel porque a pesar de su corta edad demostraron ser más maduros que muchos adultos, superando la distancia con valentía, porque siempre existen momentos y fechas en los que el amor y la presencia de una madre es indispensable y, ellos supieron enfrentarlos sin tenerme a su lado.

A mi Padre, por la paciencia y cariño con los que cuido de mis hijos y porque después de mis tantos errores, él siempre estuvo a mi lado, apoyándome y haciéndome sentir querida, por todas sus palabras de aliento y lo más importante, que por ser como es, puedo decir con orgullo, que tengo al mejor Padre del mundo.

Y una dedicación muy especial a la persona que me ayudo a encontrar mi verdadera vocación y gracias a eso, elegí la profesión de médico veterinario, esa persona que con su ejemplo me ha enseñado que jamás tenemos que darnos por vencidos y que en la vida, todo se puede conseguir, siempre y cuando estemos dispuestos a luchar y a sacrificar alguna cosa, pero sabiendo que al final, siempre tendremos una excelente recompensa. Esa persona de la que hablo no solo se ha ganado mi admiración y respeto, sino el de muchas personas más, y no porque es mi Madre, sino por ser una Mujer ejemplar.

No me alcanzarían todas las hojas del mundo para escribir lo mucho que les agradezco y el inmenso amor que siento por ustedes, espero poderles recompensar algún día todo lo que han hecho por mí, Gracias. 
Índice de Contenidos 
I. INTRODUCCIÓN Y OBJETIVOS. .1

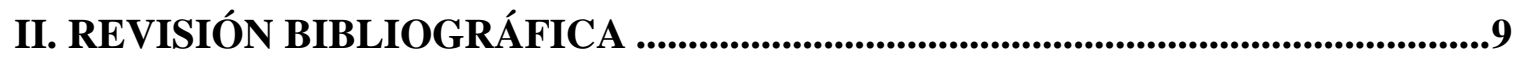

II.1. ETIOLOGÍA DE LAS MICOBACTERIAS ...........................................................11

II.2. TUBERCULOSIS BOVINA …………………........................................13

2.1. Importancia de la tuberculosis bovina en la inspección post mortem ........14

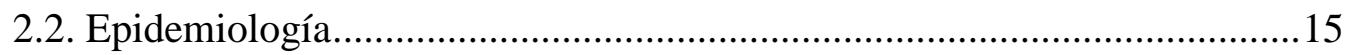

2.2.1. Hospedadores susceptibles a Mycobacterium bovis .....................17

2.2.1.1. Hombre ............................................................................ 17

2.2.1.2. Tejón (Meles meles).............................................................. 18

2.2.1.3. Zarigüeya (Trichosorus vulpécula) ......................................... 18

2.2.1.4. Otras especies silvestres ........................................................ 18

2.2.1.5. Especies domésticas ............................................................ 19

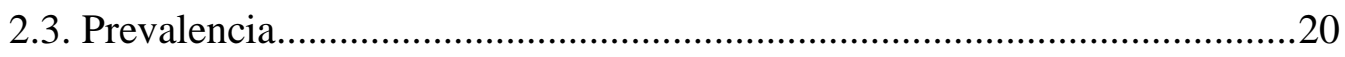

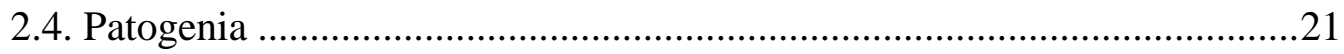

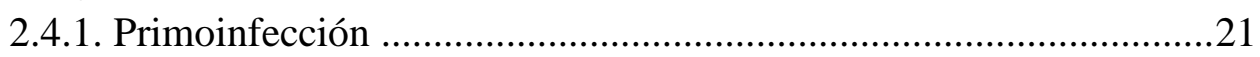

2.4.2. Período post-primario .............................................................22

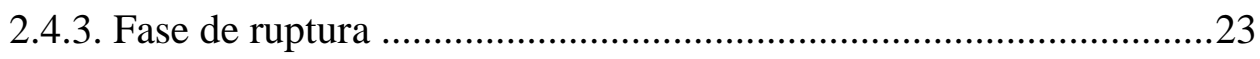

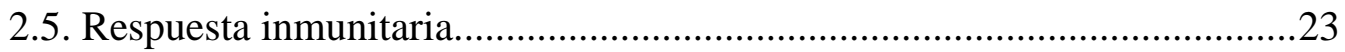

2.6. Signos clínicos y lesiones macroscópicas ...............................................25

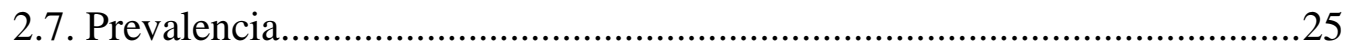

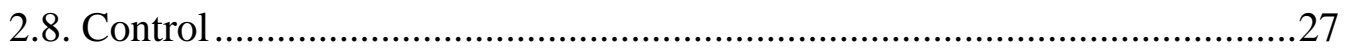

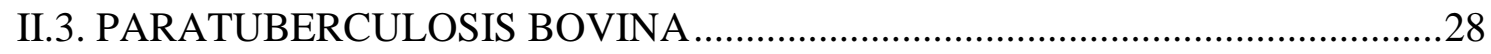

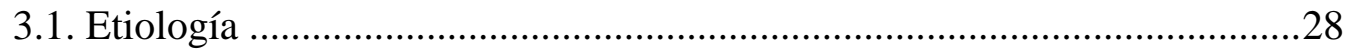

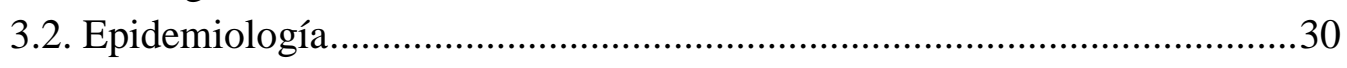

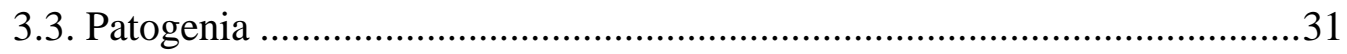

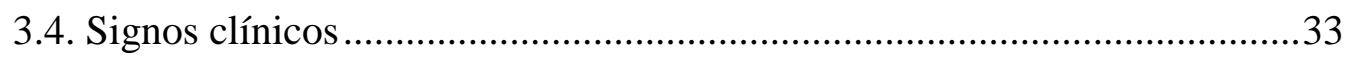

3.4.1. Lesiones macroscópicas ....................................................... 34

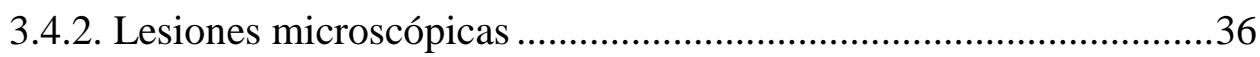

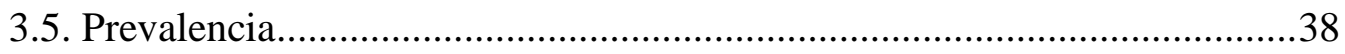

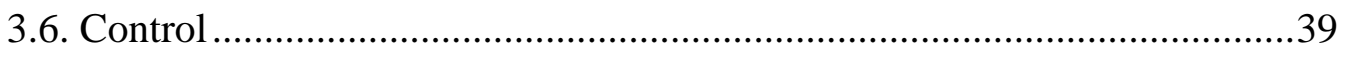

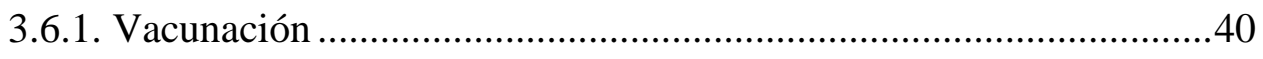

II.4. DIAGNÓSTICO DE LAS MICOBACTERIAS ................................................40

4.1. Diagnóstico clínico y epidemiológico .................................................4 41 


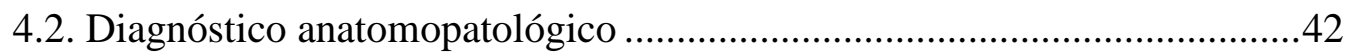

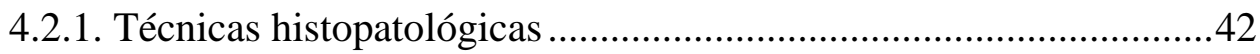

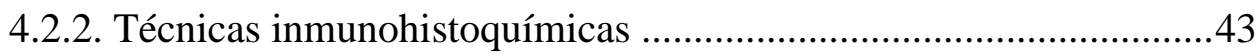

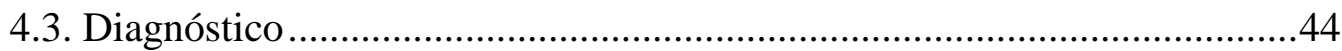

4.3.1. Aislamiento e identificación en cultivo bacteriológico ......................44

4.3.2. Detección del genoma micobacteriano (PCR)...................................45

4.4. Métodos diagnósticos basados en la respuesta inmune del animal .............47

4.4.1. Métodos diagnósticos basados en la respuesta inmune celular ........48

4.4.1.1. Prueba de la tuberculina ...............................................................48

4.4.2. Métodos diagnósticos basados en la respuesta inmune

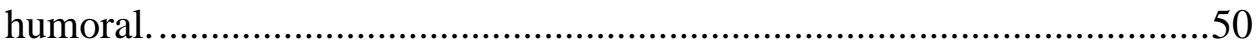

4.4.2.1. Prueba de inmunodifusión en gel de agar (IDGA) .........................51

4.4.2.2. Ensayo inmunoenzimático (ELISA) ............................................52

4.4.2.3. La prueba de gamma interferón......................................................53

III. MATERIALES Y MÉTODOS _......................................................................55

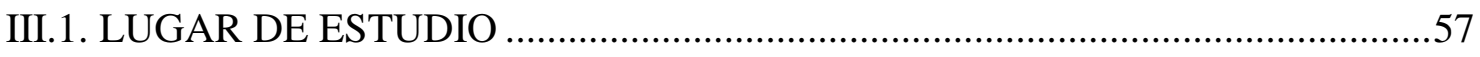

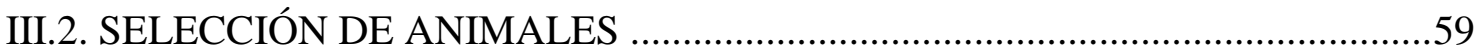

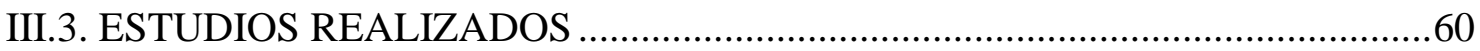

3.1. Intradermorreacción (IDR) simple. ..............................................................60

3.2. Prueba del test ELISA indirecto frente a tuberculosis $y$

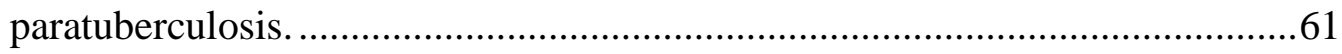

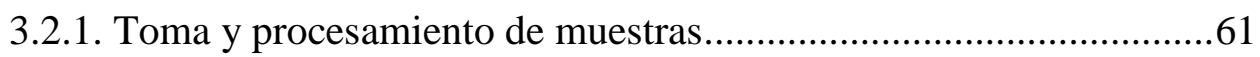

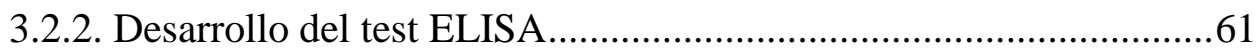

3.2.3. Validación del test ELISA e interpretación de los resultados ..........64

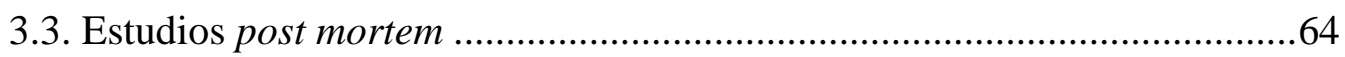

3.3.1. Estudios anatomopatológicos ........................................................64

3.3.1.1. Exámen macroscópico y toma de muestras .....................................64

3.3.1.2. Procesado histológico ..................................................................66

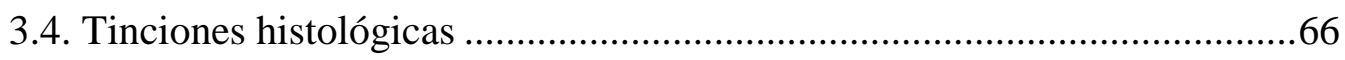

3.4.1. Valoración de las lesiones .............................................................69

3.5. Detección de micobacterias mediante PCR y selección de muestras ..........70

3.5.1. Procesado de las muestras ...........................................................

3.5.2. Lisis de la micobacteria y extracción del ADN …………………......71

3.5.3. Amplificación del ADN micobacteriano.........................................73

3.5.4. Identificación del segmento amplificado.........................................75 
III.5. MATERIAL INFORMÁTICO Y ANÁLISIS ESTADÍSTICO

IV.1. VALORACIÓN DE LA RESPUESTA INMUNE PERIFÉRICA FRENTE A TUBERCULOSIS Y PARATUBERCULOSIS .....................................................

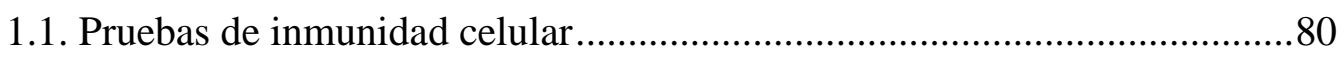

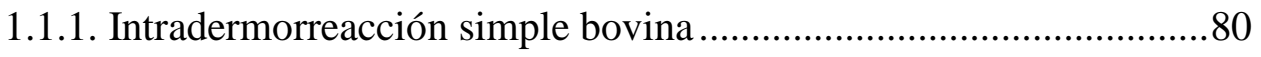

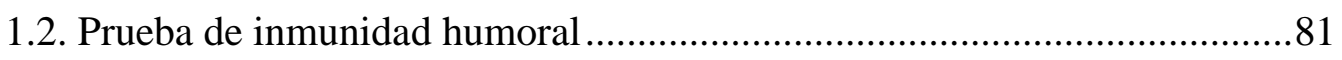

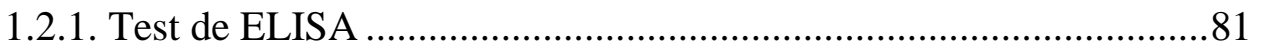

IV.2. RESULTADOS DE LOS ESTUDIOS post mortem ……………………............84

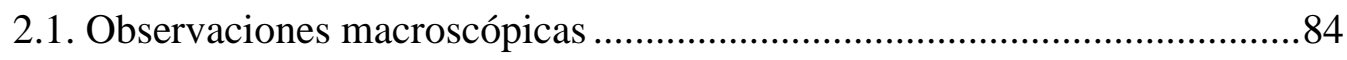

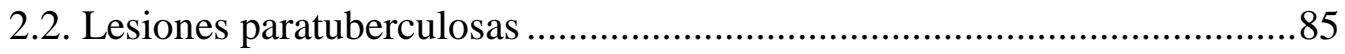

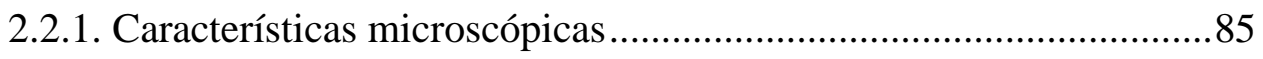

IV.3. RESULTADOS EN LA PRUEBA DE DETECCIÓN DE MICOBACTERIAS MEDIANTE LA PCR …………............................................89

IV.4. COMPARACIÓN ENTRE TÉCNICAS DIAGNÓSTICAS.................................93

4.1. Comparación entre el diagnóstico histopatológico y el diagnóstico

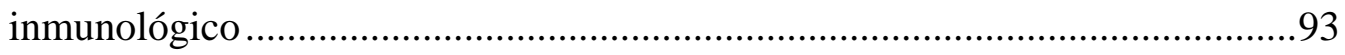

4.1.1. Comparación entre el diagnóstico histopatológico y la IDR ............93

4.1.2. Comparación entre el diagnóstico histopatológico y el ELISA ......93

4.1.3. Comparación entre el diagnóstico histopatológico y la PCR ...........95

4.1.4. Relación entre la respuesta a la intradermorreacción (IDR) y el

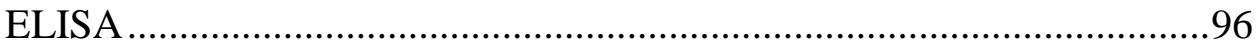

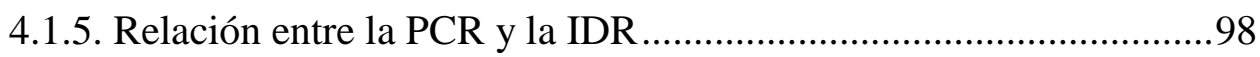

4.1.6. Relación entre la PCR y el ELISA ................................................99

4.1.6.1. Relación entre la PCR-tb y el ELISA frente a M. bovis ................99

4.1.6.2. Relación entre la PCR-tb y el ELISA frente a Map ......................99

4.1.6.3. Relación entre la PCR-ptb y el ELISA frente a M. bovis ...............100

4.1.6.4. Relación entre la PCR-ptb y el ELISA frente a Map ....................100

4.1.7. Relación entre el ELISA indirecto frente a paratuberculosis y tuberculosis 
5.1. Animales en los que se realizaron las diferentes técnicas diagnósticas, para tuberculosis y paratuberculosis

V. DISCUSIÓN

VII. RESUMEN

VIII. SUMMARY 
Índice de Tablas, Gráficas y Figuras 


\section{REVISIÓN BIBLIOGRÁFICA .............................................................................9}

Figura.II.1. Etapas de la tuberculosis en el pulmón............................................22

\section{MATERIALES Y MÉTODOS .......................................................................55}

Figura.III.1. Distribución geográfica de México ....................................................58

Figura.III.2. Distribución geográfica de Nayarit ...............................................58

Tabla.III.1. Distribución de los 343 bovinos en los 20 municipios (grupos) ..........59

Figura.III.3. Distribución de los sueros en la placa del test ELISA PPA-3 y de tuberculosis

Tabla.III.2. Preparación de los reactivos utilizados en el test ELISA

Tabla.III.3. Identificación de las muestras tomadas, tras el sacrificio de cada animal para los diferentes estudios

Figura.III.4. Localización de los ganglios linfáticos objeto de estudio

Tabla.III.4. Número de identificación, municipio de procedencia, sexo, edad y aptitud de los 62 animales en los que se realizó el estudio histológico......

Tabla.III.5. Protocolo de la tinción Hematoxilina-Eosina (H-E)

Tabla.III.6. Reactivos empleados para la tinción Hematoxilina-Eosina (H-E) .......68

Tabla.III.7. Protocolo para 1 tinción Ziehl-Neelsen $(\mathrm{Z}-\mathrm{N})$...................................69

Tabla.III.8. Reactivos empleados para la tinción Ziehl-Neelsen (Z-N).

Tabla.III.9. Componentes del kit comercial Speedtools Tissue ADN extraction kit (Biotools® B\&M Labs., S.A., Madrid, España) para la extracción y purificación de ADN 
Tabla.III.10. Reactivos empleados en la fase de amplificación de la PCR para las secuencias de inserción IS900 de Map, IS6110 de M. bovis e IS901 de Maa

Tabla.III.11. Reactivos y protocolo de preparación del gel de agarosa para la visualización de los fragmentos de ADN amplificados

Figura.III.5. Revelado de la PCR en gel de agarosa .........................................76

\section{RESULTADOS}

Gráfico.IV.1. Resultados en la prueba IDR bovina sobre 289 animales .80

Tabla.IV.1. Resultado de los grupos a la prueba de Intradermorreacción.

Tabla.IV.2. Resultado del test ELISA frente a $M$. bovis y Map .82

Gráfico.IV.2. Resultado del test ELISA sobre 320 animales .83

Tabla. IV.3. Resultado de ELISA frente a M. bovis y Map por edad .83

Figura.IV.1. Lesiones microscópicas. .86

Figura.IV.2. Lesiones de tipo 1B, negativa a la presencia de BAAR mediante la técnica de Ziehl-Neelsen.

Tabla.IV.4. Distribución del número de animales con lesiones según el grupo (municipio)

Tabla.IV.5. Identificación de los animales en los que se valoraron lesiones histológicas

Tabla.IV.6. Número de lesiones según la distribución anatómica y su tipo

Figura.IV.3. Revelado de la PCR en gel de agarosa con muestras positivas a la secuencia de inserción IS6110 de M. bovis

Tabla.IV.7. Resultado de la PCR frente a M. bovis y Map realizada sobre 275 animales .90 
Gráfico.IV.3. Porcentaje de acuerdo a la edad en la PCR frente a M. bovis y Map

Tabla.IV.8. Resultados de la PCR realizada sobre 14 animales en los que se analizaron las tres micobacterias (M. bovis, Map y Maa) . .92

Figura.IV.4. Revelado de la PCR en gel de agarosa..... .92

Tabla.IV.9. Relación del número de animales con lesiones y la respuesta a la intradermorreacción (IDR) con PPD bovina

Tabla.IV.10. Relación entre los resultados del test ELISA frente a M. bovis.

Tabla.IV.11. Relación entre los resultados de la técnica ELISA frente a Map .......94

Tabla.IV.12. Relación entre los resultados de la PCR frente a $M$. bovis y presencia de lesiones, expresado como número de animales

Tabla.IV.13. Relación entre los resultados de la PCR frente a Map .96

Tabla.IV.14. Relación entre los resultados de la PCR frente a Maa ..... .96

Tabla.IV.15. Número de animales IDR positivos y negativos a la prueba ELISA frente a $M$. bovis

Tabla.IV.16. Número de animales IDR positivos y negativos al test ELISA frente a Map

Tabla.IV.17. Número de animales PCR positivos y negativos frente a $M$. bovis y a la IDR simple bovina. . .98

Tabla.IV.18. Número de animales PCR positivos y negativos frente a Map y a la IDR simple bovina

Tabla.IV.19. Número y porcentaje de animales PCR (frente a $M$. bovis) positivos y negativos al test ELISA frente a $M$. bovis 
Tabla.IV.20. Número y porcentaje de animales PCR (frente a M. bovis) positivos y negativos al test ELISA frente a Map

Tabla.IV.21. Número y porcentaje de animales PCR (frente a Map) positivos y negativos al test ELISA frente a $M$. bovis

Tabla.IV.22. Número y porcentaje de animales PCR (frente a Map) positivos y negativos al test ELISA frente a Map

Tabla.IV.23. Número de animales positivos y negativos al test ELISA frente a M. bovis y Map

Tabla.IV.24. Porcentaje de animales positivos a las diferentes técnicas diagnósticas

Gráfico.IV.4. Porcentaje de la positividad de los grupos de animales a los que se aplicaron las diferentes técnicas diagnósticas

Tabla.IV.25. Resultado de las diferentes técnicas diagnósticas realizada en 35 animales

Gráfico.IV.5. Resultado de las diferentes técnicas diagnósticas realizada en 35 animales, expresados como porcentaje de animales

Tabla.IV.26. Relación de todos los animales incluidos en el estudio, así como los resultados de todas las pruebas diagnósticas realizadas. 


\section{INTRODUCCIÓN Y OBJETIVOS}

"Nunca consideres el estudio como una obligación, sino como una oportunidad para penetrar en el bello y maravilloso mundo del saber". Albert Einstein (1879-1955). 
La tuberculosis bovina es una enfermedad infecto contagiosa crónica, de carácter granulomatoso, causada por bacterias del complejo Mycobacterium tuberculosis principalmente Mycobacterium bovis [Draper, 1982; Cousins, 2001; Magnano et al., 2010] que ocasiona serios problemas en la salud pública al tratarse de una zoonosis [Grange, 2001; Magnano et al., 2010].

En el ganado bovino esta enfermedad crónica y debilitante, se caracteriza por la formación de granulomas llamados tubérculos, los cuales pueden aparecer en cualquier tejido, aunque las lesiones más frecuentes suelen observarse en los ganglios linfáticos ubicados en la cabeza o tórax y en el pulmón [Buddle et al., 1994; Wobeser, 2009]. La aparición de lesiones en otros órganos (glándula mamaria, riñón, hígado, etc.) se debe a la diseminación por sangre de la bacteria desde la localización primaria [Abdala y Tarabla, 2007].

Los signos clínicos pueden estar ausentes en los primeros estadios de la enfermedad y al tratarse de una zoonosis, este hecho supone un riesgo ocupacional para quienes trabajan con animales, como veterinarios, ganaderos y personal de mataderos, entre otros [O’Reilly y Daborn, 1995].

La tuberculosis en el ganado bovino tiene gran importancia económica, ya que además de las pérdidas directas ocasionadas por la muerte de los animales, provoca pérdidas de peso, disminución en la producción láctea y afecta a la fertilidad [WHO, 1994; Surujballi et al., 2009]. Dado que la distribución de la tuberculosis bovina no es homogénea, la inmovilización y comercialización de ganado se encuentra restringida. Esto ha tenido consecuencias para México ya que la movilización y comercialización de los animales se ha visto limitada a causa de la enfermedad, convirtiéndose en una de las principales barreras no arancelarias [Zendejas et al., 1997].

La tuberculosis bovina en los últimos años ha sido un foco de atención en México, no solo por el hecho del incremento en el número de casos, sino también por las políticas de comercio que se establecen con otros países, incluidos los programas de inocuidad alimentaria, lo cual ha provocado un renovado interés por el desarrollo y validación de nuevas alternativas de control y mejores métodos de diagnóstico [Rothel et al., 1990; Buddle et al., 2003]. Por ello, al igual que en otras regiones del mundo, en México también se han iniciado programas gubernamentales para controlar y erradicar la tuberculosis bovina. Esta campaña se inició en 1971 [Zendejas et al., 2007] y se basa en el diagnóstico de los animales infectados mediante la aplicación intradérmica de tuberculina (PPD) y la eliminación de los animales positivos [Beer, 1981; Blaha, 1995; Tizard, 2002; Arcelles et al., 2005]. 
Sin embargo, el diagnóstico de la tuberculosis está sometido aún a controversia. La prueba de la tuberculina o intradermorreacción, utilizada para el diagnóstico de la tuberculosis bovina desde hace más de 100años [Underwood y Carfagnini, 2005], es la técnica más empleada por su bajo costo económico y su facilidad de ejecución, si bien existen discrepancias en cuanto a los criterios para la interpretación de los resultados [Gutiérrez-Cancela, 1996].

Un hecho conocido es la existencia de animales anérgicos a la prueba de la tuberculina, que en algunos trabajos realizados en México se cita que pueden llegar a ser el 19\% de los animales muestreados [Estrada-Chávez et al., 2001]. Por ello, y atendiendo a las recomendaciones de Cicuta et al. (2003), se ha propuesto el empleo combinado de varias técnicas diagnósticas inmunológicas (detección de anticuerpos, valoración de la producción de citoquinas, etc.) que permitan obtener un perfil epidemiológico más ajustado a la situación real para poder, posteriormente adoptar las medidas de control más adecuadas. Además, una vez que los animales son eliminados, debe llevarse a cabo un diagnóstico post mortem de la tuberculosis bovina, empleando el estudio histopatológico de los órganos afectados [Vitale, 1998] junto con el diagnóstico etiológico, bien mediante métodos inmunohistoquímicos [Gutiérrez-Cancela y García Marín, 1993; Castillo et al., 2010], la aplicación de técnicas de biología molecular [Prat et al., 2010], o el cultivo bacteriológico, totalmente específico.

La vigilancia en mataderos representa un componente fundamental en el programa nacional de erradicación de la tuberculosis bovina. La inspección post mortem es un método eficiente en la detección de la infección en poblaciones de ganado, y constituye una herramienta importante para comprobar la existencia o no de la enfermedad en un hato [Corner et al., 1990; González, 2003]. Además, es útil para realizar estudios de prevalencia, incidencia y caracterización de lesiones macroscópicas de tuberculosis [García Castro, 2007]. Si se subestima este método de detección, la erradicación podría sufrir un importante retraso. [Tolson y Jervois, 1990].

La paratuberculosis (PTB) o enfermedad de Johne es una enfermedad infecciosa producida por Mycobacterium avium subespecie paratuberculosis (Map) que afecta a rumiantes, tanto silvestres como domésticos, principalmente bovinos, ovinos y caprinos, produciendo lesiones granulomatosas en el intestino y nódulos linfáticos [Pérez et al., 1996; Clarke, 1997; Forshell, 2001; González, 2003, González et al., 2005].

Aunque los individuos se infectan en los primeros días de vida, los signos clínicos no aparecen antes del año y medio o dos años de edad. El principal síntoma común para todas las especies, es el adelgazamiento progresivo que puede llegar hasta la caquexia, acompañado en ocasiones por diarrea [Stamp y Watt, 1954; Aller et al., 1973; Blood et al., 
1989; Barker et al., 1993; García Marín et al., 1994; Corpa et al., 1998a; Pávlik et al., 2000], que conduce finalmente a la muerte del animal [Manning y Collins, 2001].

Las lesiones se localizan en el aparato digestivo, afectando al intestino delgado (íleon y yeyuno preferentemente) y nódulos linfáticos regionales, y se caracterizan por una inflamación crónica de carácter granulomatoso [Harris y Barletta, 2001].

La vía de contagio principal es la digestiva. Por lo general los animales se infectan al ingerir leche y sobre todo material infectado con Map., siendo más sensibles los terneros menores de 6 meses [Chiodini et al., 1984; Blood et al., 1989; Juste y Adúriz, 1990a; Stabel, 1998; García Marín et al., 2000].

Está enfermedad es de distribución mundial [Sánchez et al., 2009]. Se considera una enfermedad emergente y es común en ganado lechero. Su mayor importancia es de tipo económico, causando graves pérdidas en rebaños lecheros debido a la disminución de la producción láctea, al descenso en la producción de terneros, a la mayor susceptibilidad a otras enfermedades, disminución de la fertilidad, a la muerte o sacrificio, de los animales afectados y a las restricciones que ocasiona en la comercialización del ganado [Merkal et al., 1975; Van Schaik et al., 1996; Johnson-Yfearundulu et al., 2000]. También debe tenerse en cuenta su posible implicación en el desarrollo de la enfermedad de Crohn humana [Chiodini et al., 1984; Chiodini, 1989; Grange et al., 1990; Dey y Parham, 1993] por lo que podría tener importancia en salud pública.

En este momento no existe tratamiento curativo viable para la enfermedad, por lo tanto su diagnóstico es fundamental para establecer medidas de control basadas en la eliminación y separación de animales conjuntamente con medidas de bioseguridad [Alfaro et al., 2006] o en la vacunación, donde sea factible utilizarla [González, 2003].

El diagnóstico clínico de la paratuberculosis en bovinos con signos evidentes (edema submandibular, diarrea crónica y pérdida progresiva de peso) no es difícil; sin embargo, el diagnóstico de la enfermedad en animales infectados asintomáticos es extremadamente complejo, ya que no existe ningún método de diagnóstico lo suficientemente eficaz para detectar todos los individuos infectados [Collins, 2004].

Dentro de las pruebas diagnósticas actualmente disponibles con mayor especificidad se encuentran aquellas basadas en la detección de Map mediante cultivo de heces, mucosa intestinal o nódulos linfáticos [Chiodini y Van Kruiningen, 1986; Merkal et al., 1987; de Lisle y Milestone, 1989] o empleando técnicas de biología molecular como el PCR [Gamboa et al., 1998; Chedore y Jamieson, 1999; Bergmann et al., 2000]. El cultivo fecal ha sido ampliamente utilizado en programas de control y se ha considerado como "Gold 
Standard", sin embargo muestra desventajas por ser laborioso, de alto costo y extremadamente lento [Swenney et al., 1995; Collins, 1996].

El otro grupo de procedimientos diagnósticos ampliamente utilizados son los métodos inmunológicos. La detección de anticuerpos frente a Map en el suero de animales infectados mediante el ELISA indirecto es muy empleada ya que contrariamente al cultivo, es fácil de realizar, rápida y de bajo costo [Cocito et al., 1994; Collins, 1996; Withlock y Buergelt, 1996; Stabel, 1998]. Sin embargo, entre sus inconvenientes se señala su baja sensibilidad, ya que no detecta a los animales que están en las fases iniciales de la infección [Collins et al., 1993a]. En los últimos años también se han empleado técnicas que evidencian la respuesta inmune celular, como la prueba del IFN- $\gamma$ [Rothel et al., 1990; Wood et al., 1990] que si detectaría animales en fases tempranas, pero que presenta limitaciones importantes en su ejecución como el tiempo reducido que debe pasar desde que se toman las muestras hasta su procesado, o el coste económico.

El diagnóstico anatomopatológico, basado en la detección de lesiones características de paratuberculosis, es de gran utilidad para confirmar la enfermedad. Las lesiones macroscópicas específicas que suelen presentarse en la mayoría de los animales afectados clínicamente de paratuberculosis pueden proporcionar un diagnóstico fiable, si bien hay que tener en cuenta que las lesiones no siempre se pueden apreciar, incluso en animales con evidentes signos clínicos [Buergelt et al., 1978; Corpa, 1999] y en la mayor parte de los que presentan la infección subclínica [González, 2003]. En estos casos es necesario realizar el estudio histopatológico, que muestra una buena sensibilidad y especificidad [Barker et al., 1993; Withlock, 1998; González et al., 2005] y es, junto al cultivo, la prueba usada como referencia para validar y comparar otras técnicas [Billman- Jacome et al., 1992; Schulaw et al., 1993; Clarke et al., 1996; Pérez et al., 1997; McDonald et al., 1999]. Además, se puede llevar a cabo un diagnóstico etiológico en tejidos mediante técnicas de PCR [Pérez et al., 2009], habiéndose demostrado que es un método sensible y específico, permitiendo detectar incluso animales con lesiones focales en las fases iniciales de la infección [Milner et al., 1989; Sockett et al., 1992; González, 2003; Delgado et al., 2013].

Los estudios sobre paratuberculosis bovina realizados en México son escasos. En un trabajo llevado a cabo en el estado de Hidalgo, por Miranda (2005) se comprobó que esta enfermedad estaba bastante extendida y era una causa importante de pérdidas económicas en el ganado bovino.

La tuberculosis y paratuberculosis guardan numerosas similitudes. En ambos casos, tienen una etiología micobacteriana, y ambos agentes comparten antígenos comunes. Desde el punto de vista lesional, se trata de inflamaciones de tipo granulomatoso, con presencia de linfocitos, macrófagos, células gigantes de Langhans y células epiteloides [Potel, 1974; Bernabé et al., 1991; Dungworth, 1993; Gutiérrez-Cancela y García Marín, 1993; 
Huchzermeyer et al., 1994]. Las principales diferencias lesionales entre tuberculosis y paratuberculosis bovina vienen dadas por su diferente localización y la morfología de las lesiones; mientras que la tuberculosis se caracteriza por la formación de granulomas bien definidos, encapsulados en las fases avanzadas [Nieberle y Cohrs, 1966; Gutiérrez-Cancela, 1996], la paratuberculosis cursa con un infiltrado difuso de células epiteloides en el intestino [Momotami y Yoshino, 1985; González, 2003].

Además, en la tuberculosis se puede observar la presencia de necrosis por caseificación que afecta principalmente al pulmón y nódulos linfáticos asociados [Nieberle y Cohrs, 1966; Gutiérrez-Cancela, 1996], mientras que en la paratuberculosis bovina la existencia de necrosis en el intestino o ganglios regionales es una alteración extremadamente rara [Momotami y Yoshino, 1985; González, 2003].

Uno de los mayores problemas que ocasiona la coexistencia de ambas enfermedades en una explotación es la complicación que añade a la interpretación de los métodos de diagnóstico inmunológico, ya que se producen reacciones cruzadas. La principal consecuencia, es la aparición de reacciones falsamente positivas, que la infección paratuberculosa puede causar en las campañas oficiales de la erradicación de la tuberculosis bovina [Johnson et al., 1949; Yokomiso et al., 1983; Nain et al., 1985; Arellano-Reynoso et al., 1999]. Por ello, para una necesaria evaluación de los métodos inmunológicos, es preciso llevar a cabo un estudio post-mortem confirmatorio de dichas infecciones, empleando técnicas de diagnóstico anatomopatológico y etiológico en tejidos.

En México son muy escasos los estudios que se han realizado sobre el diagnóstico de tuberculosis y paratuberculosis bovina en la inspección post mortem, teniéndose muy pocos datos acerca de su prevalencia. Considerando la importancia que estas enfermedades tienen en la ganadería bovina y también sus implicaciones zoonósicas, y bajo la hipótesis de que están muy extendidas en México, el objetivo general de este trabajo de tesis doctoral es contribuir a conocer la prevalencia de la tuberculosis y paratuberculosis bovinas en animales sacrificados en matadero en una región de México, y además valorar la eficacia de distintas técnicas diagnósticas para su detección. Para ello, nos hemos fijado los siguientes objetivos concretos: 


\section{Primero:}

Evaluar la eficacia del diagnóstico post mortem de tuberculosis y paratuberculosis bovina mediante el estudio macroscópico, el examen histopatológico y el diagnóstico etiológico mediante PCR en muestras de tejido seleccionadas y definidas.

\section{Segundo:}

Comparar los resultados del diagnóstico serológico frente a tuberculosis $\mathrm{y}$ paratuberculosis bovina mediante un ELISA indirecto, con los hallazgos de los estudios post mortem (histopatológicos y de PCR) en tejidos.

\section{Tercero:}

Evaluar los resultados de la prueba de intradermorreacción simple con PPD bovina en relación con el diagnóstico post mortem realizado, mediante técnicas histopatológicas y de PCR de tuberculosis y paratuberculosis, valorando la existencia de posibles reacciones cruzadas.

\section{Cuarto:}

Estudiar la relación entre los resultados del diagnóstico inmunológico mediante la prueba de intradermorreacción y el ELISA indirecto frente a tuberculosis y paratuberculosis.

\section{Quinto:}

Valorar la posibilidad de establecer protocolos eficaces de diagnóstico diferencial de tuberculosis y paratuberculosis bovina basados en una toma de muestras sencilla y de aplicación en la inspección de mataderos.

\section{Sexto:}

Establecer la prevalencia de la tuberculosis y paratuberculosis bovinas en una población de bovinos sacrificados en matadero en la región de Nayarit (México), mediante técnicas de diagnóstico inmunológico e histopatológico. 


\section{REVISIÓN BIBLIOGRÁFICA}

"La educación es el arma más poderosa que puedes usar para cambiar el mundo"

Nelson Mandela (1918-2013) 


\section{II.1. ETIOLOGÍA DE LAS MICOBACTERIAS.}

Las micobacterias se engloban dentro del género Mycobacterium, familia Mycobacteriaceae, suborden Corynebacterinae, orden Actinomicetales, subclase Actinobacteridae, clase Actinobacteria, división Firmacutes, superreino Bacteria [Stackebrandt et al., 1997; Tejedor, 2002; Smith, 2003; Pérez-Arellano et al., 2005; Mantilla, 2007].

En 1980 el género Mycobacterium estaba constituido por 41 especies, tanto patógenas estrictas como saprófitas e incluso formas intermedias, que posteriormente llegó a ampliarse a 71 especies [Skerman et al., 1980; Shinnick y Good, 1994]. Las micobacterias se encuentran estrechamente relacionadas con los géneros Corynebacterium y Nocardia [Wayne y Kubica, 1986].

Dentro del género Mycobacterium existen algunas especies que tienen entre sí un grado elevado de homología, tanto estructural como fisiológica, que obliga a considerarlas como complejos independientes dentro del género. Entre ellas, destaca el complejo Mycobacterium tuberculosis que engloba a las especies: Mycobacterium tuberculosis, la más importante a nivel sanitario, por ser la principal causa de la tuberculosis humana, Mycobacterium bovis y Mycobacterium caprae de gran importancia en países en vías de desarrollo por ser la causante de la tuberculosis animal, Mycobacterium africanum responsable minoritario de los casos de tuberculosis en África y Mycobacterium microti responsable de la tuberculosis en roedores y actualmente descrita en humanos principalmente inmunodeprimidos. Por otro lado, el complejo Mycobacterium avium que principalmente incluye a $M$. avium avium, $M$. a. intracellulare y $M$. a. paratuberculosis [Wayne y Kubica, 1986; Pritchard, 1988; Cosivi et al., 1998; Kremer et al., 1998; Van Sooligen et al., 1998; Forthingham et al., 1999; Miltgen et al., 2002; Smith, 2003; Thoen y Barletta, 2006].

Según la bibliografía consultada [Haagsma, 1993; Tejedor, 2002; Barrón et al., 2006; Sevilla, 2007] los componentes de este género muestran las siguientes características esenciales:

1) Presentan ácido-alcohol resistencia, ya que las micobacterias no se decoloran en soluciones al 3\% de ácido y 95\% de etanol después de haber sido teñidas con colorantes básicos. Esta resistencia es una propiedad conferida por su membrana constituida por ácidos micólicos de 60-90 carbonos, que evita la eliminación de los colorantes una vez absorbidos.

2) Débilmente positivas a la tinción de Gram. 
3) Son inmóviles.

4) No forman esporas, cápsula, conidios ni hifas visibles sin embargo, son más resistentes al calor, cambios de $\mathrm{pH}$ y desinfección, que otras bacterias no formadoras de esporas.

5) Crecen en condiciones aerobias.

6) La morfología se corresponde con bacilos delgados, rectos o ligeramente curvados, aunque en menor proporción suelen presentar crecimiento filamentoso o pseudomiceliar del que pueden desprenderse formas bacilares o cocáceas.

La temperatura óptima de crecimiento es entre 30 y $45^{\circ} \mathrm{C}$, y el contenido en $\mathrm{G}+\mathrm{C}$ del ADN cromosómico es del 61-71\% [Wayne y Kubica, 1986; Levy-Frebault y Portaels, 1992; Tejedor, 2002; Mantilla, 2007; Sevilla, 2007].

Las principales propiedades estructurales y antigénicas de las micobacterias son su compleja pared celular, que se encuentra internamente formada por una capa de peptidoglicanos llamada mureína, que se encarga de dar rigidez y forma y es, la responsable del poder adyuvante de la micobacteria; más externamente se encuentra la capa de arabinogalactano a la que se unen los ácidos micólicos como sulfolípidos y dimicolatos de trealosa (cord factors) hacia el exterior siendo los principales responsables de la ácidoalcohol resistencia [Merkal et al., 1975; Stanford, 1983; Chiodini y Van-Kruiningen, 1985; Grange et al., 1990; Daffe y Draper, 1998]. Por último, la capa más externa está formada por micósidos, un complejo grupo de glucolípidos de superficie, específicos de especie y que permite a las micobacterias patógenas resistir a la acción de las enzimas lisosómicas [Grange et al., 1990].

Una de las características sin duda más conocidas de su identidad es su propiedad de resistencia a la decoloración con ácidos y alcoholes, debido a su alto contenido de lípidos en la pared celular micobacteriana, hasta un $60 \%$ de su peso seco [López et al., 2006]. Dicha característica estructural de las micobacterias es la responsable de que éstas crezcan como colonias hidrofóbicas en medios sólidos o en medios líquidos como filamentos de tipo fúngico. Este aspecto que presentan en el medio líquido, da nombre al género, puesto que myces significa hongo [Wolinsky, 1980].

Otras características de las micobacterias que son empleadas en la diferenciación de especies, hacen referencia a su desarrollo en nuevos medios de cultivo, velocidad de crecimiento y dependencia de ciertas sustancias como las micobactinas [Goodfellow y Wayne, 1982; Chiodini, et al., 1984; Thorel, 1984; Marco y Adúriz, 1990; Juste, 1997]. 
Por último, queda por introducir el concepto de micobacterias atípicas, oportunistas conocidas como MOTT (micobacteria other than tubercle bacilli) que son aquellas micobacterias saprofitas del medio ambiente que no producen tuberculosis, ni se transmiten entre los hospedadores, pero tienen gran importancia como agentes sensibilizadores en diferentes test diagnósticos de la tuberculosis [Pritchard, 1988] ya que siendo unas oportunistas pueden aislarse en muestras patológicas.

\section{II.2. TUBERCULOSIS BOVINA.}

La tuberculosis bovina es una enfermedad infectocontagiosa que causa significativas pérdidas económicas a nivel mundial, tanto por la muerte de animales como por los recursos destinados a su erradicación, ya que se trata de una zoonosis y son muchas las muertes humanas que se producen como consecuencia de la infección por la micobacteria causal. Esta infección crónica producida por Mycobacterium bovis (M. bovis), afecta principalmente al aparato respiratorio y cursa con la emaciación progresiva e incluso la muerte de los animales afectados, en los que se observa una inflamación de carácter granulomatoso en diferentes órganos, especialmente pulmones y nódulos linfáticos regionales. [Retamal y Ábalos, 2004; Smith et al., 2006; Acosta-Salinas, et al., 2009; García-Bocanegra et al., 2010].

La existencia de infecciones por micobacterias data de hace miles de años, habiéndose encontrando el agente incluso en momias egipcias. Se estima que el bacilo de la tuberculosis se estableció con el desarrollo urbano en la Edad Media en Europa, para luego diseminarse al Nuevo Mundo con los viajes de los descubridores, aunque la enfermedad ya existía en personas en América por lo menos 700 años antes de nuestra era [Ábalos y Retamal, 2004].

La prevalencia de la enfermedad a nivel mundial es aún muy elevada, pese a las numerosas y largas campañas de erradicación que se han llevado a cabo en muchos de los países. Gracias a la prueba de intradermorreacción (IDR) en países como Dinamarca, Holanda, Luxemburgo, Gran Bretaña, Estados Unidos y Australia se considera erradicada [Pritchard, 1988; Caffrey, 1994; Huchzermeyer et al., 1994; McDonald et al., 1999; Maartens y Wilkinson, 2007; WHO, 2009; Mouriño et al., 2011].

La tuberculosis bovina es considerada una zoonosis grave. Sus víctimas se encuentran, sobre todo, entre la población de las zonas rurales, obligadas a vivir en estrecho contacto con los animales; además, la ignorancia y las deficientes condiciones higiénicas y de manejo de los animales favorecen el contagio y dificultan el establecimiento y éxito de las medidas de control de la enfermedad de los bovinos, con el fin de su erradicación [Pritchard, 1988; Neil y Pollock, 2000; Solmaz et al., 2009]. 
La epidemia mundial del síndrome de inmunodeficiencia adquirida (SIDA) ha favorecido el desarrollo de la tuberculosis en seres humanos. Es especialmente preocupante en África donde el $94 \%$ de la población vive en países en los cuales el control de tuberculosis bovina no se lleva a cabo o se hace parcialmente [Ábalos y Retamal, 2004].

\subsection{Importancia de la tuberculosis bovina en la inspección post mortem.}

En México, como en otros muchos países existen diversas normas oficiales en las que se regulan las características idóneas para los centros de sacrificio, y la manera en que los animales deben ser sacrificados, con su respectiva verificación sanitaria para el proceso de producción de la carne [Villanueva y De Aluja, 1998]. En este país la encargada de emitir estas normas es la Secretaría de Ganadería, Agricultura y Desarrollo Rural (SAGAR), fundamentadas en la Ley Federal sobre la Metrología y Normalización, en el reglamento interior de la Secretaría, y el Reglamento de la Industrialización Sanitaria de la Carne Tipo Inspección Federal (TIF). Además existen manuales sobre el manejo de la carne, emitidos por la Secretaría de Salud (SSA) con base en la Ley Federal de Sanidad Animal. [Villanueva y De Aluja, 1998].

Las normas oficiales más importantes para los centros de sacrificio animal en México son: la Norma Oficial Mexicana 194-SSA1-2004 que tiene como objeto establecer las especificaciones sanitarias que deben cumplirse en los establecimientos dedicados al sacrificio y faenado de animales para consumo humano, así como las especificaciones sanitarias que deben cumplir los productos [NOM-194-SSA1-2004], la Norma Oficial Mexicana 006-SSA2-1993 cuyo objeto es la prevención y control de la tuberculosis en la atención primaria a la salud [NOM-006-SSA2-1993] y la Norma Oficial Mexicana 031ZOO-1995 que tiene como función principal la prevención, control y erradicación de las plagas y enfermedades que como la tuberculosis bovina afectan a la ganadería, a la producción animal y, al comercio nacional e internacional, (no sólo por lo que se refiere a la calidad de los productos de origen animal sino por ser un problema de tipo zoonósico y de salud pública). [NOM-031-ZOO-1995; Cosivi et al., 1998; Renwick et al., 2007]. Dichas normas cuentan con la aprobación del Comité Consultivo Nacional de Normalización de Regulación y Fomento Sanitario, y son publicadas en el Diario Oficial de la Federación, de acuerdo a lo previsto en la Ley Federal sobre Metrología y Normalización.

La vigilancia en mataderos representa un componente fundamental en el programa nacional de erradicación de la tuberculosis bovina. Es muy importante realizar la inspección post mortem de manera minuciosa y más, cuando se trata de la única herramienta de monitorización de la tuberculosis [Corner et al., 1991; Estrada-Chávez et al., 2004]. Este es un método eficiente en la detección de infección y permite comprobar la existencia o no de la enfermedad en un hato [Corner et al., 1990; González, 2003]. Además 
la inspección post mortem es útil para realizar estudios de prevalencia y caracterización de lesiones macroscópicas de tuberculosis [García Castro, 2007].

Actualmente en América Latina, la tuberculosis bovina es un problema de salud grave tanto en la especie humana como en bovinos y se encuentra lejos de ser erradicada, por lo que la inspección post mortem es una herramienta fundamental que debe ser aplicada en los programas de control [Tolson y Jervois, 1990; López et al., 2006].

Para la inspección post mortem de la tuberculosis bovina se realiza la incisión de los ganglios linfáticos de la cabeza (mandibulares, parotideos y retrofaríngeos), tórax (mediastínicos y traqueobronquiales) y abdomen (mesentéricos) [NOM-031-ZOO-1995], además de la inspección, palpación e incisión de diversos órganos, especialmente el pulmón. Se trata de un procedimiento convencional que se lleva a cabo en todos los animales sacrificados en los mataderos de México, al igual que en otros países. Los hallazgos de lesiones tuberculosas en la inspección post mortem y los posteriores estudios de laboratorio son fundamentales en el diagnóstico de la tuberculosis bovina [López et al., 1997].

La experiencia de muchos países ha demostrado que la inspección post mortem es necesaria en la vigilancia epidemiológica, y la información que puede aportar posee un valor indiscutible, siendo este un método de seguimiento complementario a la tradicional prueba tuberculínica. [Torres y Kantor, 1996].

\subsection{Epidemiología.}

En la epidemiología de la infección por $M$. bovis se describen dos tipos de hospedadores: los de mantenimiento que, son los capaces de infectarse, enfermar y diseminar la bacteria a otros individuos susceptibles, permitiendo que la infección se establezca en las poblaciones en ausencia de otra fuente de infección, y los incidentales o también conocidos como los "spillover hosts", capaces de infectarse y cursar con la enfermedad, pero en los que es infrecuente la diseminación a otros individuos, ya que se requiere de una fuente externa de infección para mantener la enfermedad en la población. Del total de especies susceptibles, la mayoría son hospedadores incidentales, incluido el ser humano [Ábalos y Retamal, 2004]. Cuando alguno de los tipos de hospedadores actúan como reservorios en la naturaleza, la erradicación de la tuberculosis bovina es muy complicada [Morris et al., 1994].

La transmisión de la enfermedad puede tener diversas vías de infección, aunque se considera producida principalmente por vía aerógena y por contacto directo [Ritchie, 1959; Schulz y Trautwein, 1985; O’Reilly y Daborn, 1995]. Nieberle (1931) a través del estudio 
de la localización anatómica de las lesiones encontradas en mataderos, sugirió que la vía aerógena infectaba entre el 80 y 90\% del ganado bovino por inhalación de las partículas de Pflüger cargadas de bacilos [Collins et al., 1994; Vanham et al., 1997; Hernández et al., 2000; Michel et al., 2010; Rivera y Giménez, 2010]. Francis (1947) corroboró estos datos y señaló que sería necesaria una dosis infectiva muy baja en el pulmón, incluso una sola bacteria, para que se establezca una infección efectiva en el bovino [Ábalos y Retamal, 2004]. Sin embargo, para Chaussé (1913) se necesitarían al menos cinco bacilos para desarrollar la infección en el pulmón.

Algunas investigaciones llevadas a cabo para estudiar la transmisión de la infección [Costello et al., 1998] muestran que bovinos infectados de forma natural, con tubérculos pulmonares, pueden ser fuente de infección para otros bovinos cuando permanecen en alojamientos cerrados, sin ventilación adecuada, como ocurre en los sistemas de producción intensivos, que contrariamente a los extensivos, facilitan el contacto directo de los animales y favorecen la propagación de la tuberculosis y numerosas enfermedades respiratorias [Radosistis et al., 1994; Cousins, 2001; Thrusfield et al., 2001]. Esto puede ser la causa de que la prevalencia de tuberculosis en el ganado varíe según el sistema de producción, estimándose que en el ganado vacuno en régimen extensivo se sitúa entre el 1 y $5 \%$, mientras que en ganado lechero puede alcanzar el 25-50\% [Francis, 1947].

Además de la vía respiratoria, existen otras menos comunes, como la alimentaria (tuberculosis alimentaria o enterógena), la cutánea, la congénita a través de la vena umbilical que en ausencia de medidas de control se produciría en el $1 \%$ de los terneros nacidos de vacas tuberculosas, causando lesiones en hígado y la genital, que origina lesiones en útero y en pene [Nieberle, 1931; Francis, 1947; Ritchie, 1959; Pallaske, 1962; Schulz y Trautwein, 1985; O’Reilly y Daborn, 1995]. En el caso de la tuberculosis humana de origen bovino, un buen número de casos cursan como tuberculosis digestivas o escrófula (inflamación de los nódulos linfáticos cervicales), atribuidas al consumo de leche no pasteurizada [Pritchard, 1988]. Entre el 1 y $2 \%$ de las vacas tuberculosas eliminan el bacilo por leche [O’Reilly y Daborn, 1995; Zanini et al., 1998; Abdala y Tarabla, 2007].

El agente causal de la tuberculosis bovina, no expuesto a la luz solar, puede sobrevivir en heces, sangre y orina aproximadamente un año a temperaturas de 12 a $14^{\circ} \mathrm{C}$, periodo que se reduce a 18-31 días si existe dicha exposición y si la temperatura es más elevada (entre 24 y $43^{\circ} \mathrm{C}$ ) [Abdala y Tarabla, 2007; Sánchez et al., 2009]. 


\subsubsection{Hospedadores susceptibles a Mycobacterium bovis.}

\subsubsection{Hombre.}

El hombre es un hospedador reconocido de $M$. bovis y se ha señalado que es posible la transmisión de esta infección entre personas [Pritchard, 1988; Van Soolingen et al., 1994]. M. bovis puede causar los mismos cuadros patológicos en el hombre que $M$. tuberculosis [Ácha y Szyfres, 2001].

La OMS estimó que la incidencia de la tuberculosis en la especie humana durante la última década, en todo el mundo ha aumentado de manera preocupante, refiere que en 2005 hubo 88 millones de nuevos casos en personas [Araujo et al., 2008]. A nivel mundial $M$. bovis fue responsable del 2 al $8 \%$ de los casos de tuberculosis en humanos [Pérez-Guerrero et al., 2008].

En algunas regiones de México la participación de $M$. bovis en casos de tuberculosis humana, se ha estimado hasta en un $7 \%$ mientras que en la zona fronteriza de los Estados Unidos la proporción llega hasta un 40\% [Acosta-Salinas et al., 2009; Milián Suazo et al., 2012]. Sin embargo, la información epidemiológica que se tiene sobre la implicación de este agente etiológico es escasa, por las siguientes razones:

1) El diagnóstico se realiza por baciloscopía que no permite distinguir $M$. bovis de $M$. tuberculosis. Sólo en un $1 \%$ de los casos se realiza cultivo bacteriológico.

2) Cuando se realizan cultivos se utiliza principalmente el medio Löwenstein-Jensen en el que $M$. bovis crece con dificultad.

3) Debido a su mecanismo de transmisión, la mayor parte de las infecciones por $M$. bovis son pulmonares, siendo difíciles de detectar, por lo que prácticamente no son notificadas [Vourinen et al., 1995; Yajko et al., 1995; Forthingham et al., 1999; Araujo et al., 2008].

Aunque la obligación de pasteurizar la leche y el control de la tuberculosis bovina han ocasionado un incremento de la vía aerógena como principal forma de contagio entre el hombre y el ganado bovino en uno y otro sentido [Morales et al., 2008], aún en 1992 en México se produjeron siete millones de litros de leche y sólo un $20 \%$ de ella fue pasteurizada. Un $40 \%$ de leche sin pasterizar fue destinado a la industria de derivados mientras que el 40\% restante fue consumido sin tratamiento térmico [Yañez et al., 1996]. 


\subsubsection{Tejón (Meles meles).}

La primera descripción de tuberculosis en el tejón se remonta a 1956 en Suiza [Bouvier et al., 1957]. Posteriormente, en Gran Bretaña se demostró la importancia de estos animales en la epidemiología de la tuberculosis bovina, tras el hallazgo de tejones tuberculosos en el curso de una investigación sobre las causas de un inexplicable foco de tuberculosis en ganado bovino [Collins et al., 1994].

La participación del tejón se considera el principal reservorio de vida libre en Irlanda y Gran Bretaña. Los datos sobre su prevalencia únicamente existen en estos países, siendo especialmente elevada en las zonas sur y oeste de Gran Bretaña, donde la prevalencia de tuberculosis en vacas es más alta [Gallagher y Clifton-Hadley, 2000; Delahay et al., 2002]. Un trabajo realizado por Bourne y colaboradores en 2007 encuentra una prevalencia que oscila entre el 2 y $37 \%$ en tejones procedentes de 10 zonas de alta prevalencia de tuberculosis bovina en el sur de Inglaterra [Bourne et al., 2007]. En otros países como Suiza [Bouvier et al., 1957] y España [Sobrino et al., 2008; Balseiro et al., 2013] también se ha identificado la infección tuberculosa en esta especie animal.

Los tejones frecuentan los lugares de pastoreo, escarbando en busca de gusanos y es ahí donde excretan $M$. bovis por las heces, orina, esputos y a través de lesiones abiertas [Muirhead et al., 1974; Wilesmith, 1991; O’Reilly y Daborn, 1995]. Aunque se desconoce el grado exacto de intervención del tejón en la epidemiología de la tuberculosis bovina, su papel como reservorio se ha considerado una de las causas fundamentales del fracaso de los programas de erradicación de la tuberculosis. [Griffin y Buchan, 1993].

\subsubsection{Zarigüeya (Trichosorus vulpécula).}

El primer hallazgo de un caso natural de tuberculosis en la zarigüeya se produjo en 1967 en una granja en Nueva Zelanda con tuberculosis endémica [Pfeiffer y Morris, 1991; Morris et al., 1994]. La prevalencia de la tuberculosis en la zarigüeya ronda el 5\%, encontrándose las lesiones de carácter exudativo y con presencia de gran número de bacilos en el aparato respiratorio y en los ganglios linfáticos superficiales [Pfeiffer y Morris, 1991; Morris et al., 1994; Tweddle y Livingston, 1994; Ryan et al., 2006]. El único programa de control de tuberculosis en esta especie ha consistido en la eliminación de animales en las áreas afectadas, ya que la zarigüeya se considera una plaga en Nueva Zelanda, por lo que la medida ha sido favorablemente aceptada. [Ryan et al., 2006].

\subsubsection{Otras especies silvestres.}

La tuberculosis bovina en animales salvajes se describió por primera vez en 1929 en Sudáfrica en el kudú (Tragelaphus strepsiceros) y en el duiker (Sylvicapra grimmi) 
[Michel, 2002]. En Uganda se determinó en 1982 una prevalencia del 10\% en el búfalo africano (Syncerus caffer) y del 9\% en el cerdo verrucoso (Phacochoerus aethiopicus). [Michel et al., 2006].

En Zambia se describió en el kafue lechue (Kabus leche kafuensis) y en un eland (Traurotragus oryx) [Koniha et al., 1980]. En Kenia en los babuinos verdosos salvajes (Papio cycocephalus anubis) [Bengis et al., 1996; de Lisle et al., 2001]. También se ha diagnosticado la infección por M. bovis en búfalos africanos del Parque Nacional Kruger de Sudáfrica $\mathrm{y}$, más recientemente, se han encontrado afectadas otras especies como el babuino chacma (Papio ursinus), el león (Panthera leo) y el guepardo (Acynonyx jubatus) [Koniha et al., 1980; Bengis et al., 1996; de Lisle et al., 2001; Wobeser, 2009].

Así mismo, se ha comprobado de forma esporádica la presencia de tuberculosis en animales silvestres que viven en zoológicos, en granjas, en laboratorios, en casas o cerca del hombre o de los animales domésticos, como las cabras salvajes [Sanson, 1988], cerdos salvajes [Corner y Pearson, 1978], llamas [Thoen et al., 1988], el búfalo de agua, ciervo salvaje, foca, jabalí, etc. [Naranjo et al., 2008; Santos et al., 2009] Estas especies parecen ser transmisoras de la enfermedad en un número bajo de casos [Guilbride et al., 1963; Hein y Tomasovic, 1981; Clifton-Hadley y Wilesmith, 1991; Mirsky et al., 1992; Cousins et al., 1993; Thorel y Moutou, 1994].

También se ha descrito la enfermedad en primates no humanos y grandes félidos [O’Reilly, 1993a] así como brotes en explotaciones de visones y zorros plateados, sobre todo en Canadá, donde la tuberculosis bovina es endémica en visones salvajes [Van Soolingen et al., 1994]. De forma esporádica, descripciones esporádicas aparecen en conejos [Gill y Jackson, 1993], en liebre [Cooke et al., 1993] y hurones [de Lisle et al., 1993]. En España M. bovis fue aislado a partir de muestras de ciervos, gamos, lince ibérico y liebre [Aranaz et al., 2004; Hermoso de Mendoza et al., 2006; Parra et al., 2006; Vicente et al., 2006; Gortázar et al., 2008].

\subsubsection{Especies domésticas.}

La infección por M. bovis también se ha descrito, aunque habitualmente como casos aislados, de forma esporádica en animales domésticos como el perro, gato, cerdo, caballo y oveja, entre otros [Luke, 1958; Corner y Pearson, 1978; Morris y Pfeiffer, 1995; Palmer, 2007]. Sin embargo, son la especie bovina y caprina las que parecen mostrar una mayor susceptibilidad. 


\subsection{Prevalencia.}

La Organización Mundial de la Salud (OMS) ha estimado que la incidencia de la tuberculosis humana en la población mundial durante la década 1990-1999 fue de 88 millones de casos con una mortalidad de 30 millones de personas [Poumián, 2000]. Así mismo, se estima que entre los años 2002 y 2020 en todo el mundo aproximadamente 1.000 millones de personas se infectarán, más de 150 millones desarrollarán la enfermedad y 36 millones morirán de tuberculosis [NOM-031-ZOO-1995].

La tuberculosis en humanos ocupa en México el lugar número 17 entre las causas de muerte y el primero como causa de muerte por un solo agente infeccioso. De acuerdo con las notificaciones de los casos de tuberculosis, en todas sus formas, remitidas a la Organización Panamericana de la Salud/Organización Mundial de la Salud en 1996, México se encuentra entre los países de América con tasas de incidencia entre 25 y 85/100 000 [Morán et al., 2000].

Se calcula que Mycobacterium bovis es responsable de aproximadamente un 3\% de los casos de tuberculosis humana en el mundo [López et al., 2006]. En México, la tuberculosis humana de origen animal tiene una prevalencia aproximada del 17\% [PérezGuerrero et al., 2008]. Como hemos comentado anteriormente, de los 7 mil millones de litros de leche que se producen, aproximadamente entre el 30 y $40 \%$ se consume sin pasterizar y esta podría ser la causa de la elevada prevalencia de la infección [López et al., 2006; Pérez-Guerrero et al., 2008].

Respecto a la tuberculosis bovina, en la inspección post-mortem en ganado no procedente de las Campañas de Saneamiento, se han encontrado los siguientes datos de prevalencia:

Un 0,16\% de prevalencia en Uberlandia (Brasil) determinada en el periodo de 1979 a 1983 tras la inspección de 161.437 bovinos [Oliveira et al., 1986]. En Sao Paulo y otros estados brasileños fueron inspeccionados un total de 1.495 .976 vacunos en 1982 , presentando tuberculosis en un 0,36\% [Ricetti et al., 1989]. En el periodo de 1984-1996 en el matadero de Triangulo (Brasil) se observó una prevalencia del 0,13\% de un total de 281.326 vacunos sacrificados [Oliveira et al., 1999].

En los Estados Unidos, en 1989 se sacrificaron 33.500.000 bovinos, de los cuales sólo el 0,0004\% tenían lesiones tuberculosas [Ácha y Szyfres, 2001]. En 1995 esta prevalencia alcanzó un 0,05\% cuando se refirió a vacunos procedentes de México [Brown y Hernández de Anda, 1998]. 
En México, López et al. (1997) realizaron un estudio en 505 decomisos por tuberculosis, donde un $49 \%$ fueron clasificados como micobacteriosis y el $51 \%$ restante fue compatible con otros diagnósticos diferenciales (actinobacilosis, actinomicosis, granuloma eosinofilíco). En seis mataderos de México entre 1996 y 1997 se observaron lesiones macroscópicas de tuberculosis en el $16 \%$ de 2.500 vacunos inspeccionados (93\% mayores de 2 años) [Milián Suazo et al., 2000]. En Baja California, donde anualmente se sacrifican unos 200.000 vacunos, en 1995 y 1996 se obtuvo una incidencia en la inspección post mortem del 0,12\% y del 0,46\% respectivamente. [Hernández de Anda et al., 1997].

\subsection{Patogenia.}

Clásicamente, en la patogenia de la tuberculosis bovina se han reconocido diferentes fases, desde que el animal entra en contacto con $M$. bovis hasta que se producen las formas clínicas más graves, que se describen a continuación [Nieberle y Cohrs, 1966; Potel, 1974; Dahme y Weiss, 1988]:

\subsubsection{Primoinfección.}

Cuando el bacilo penetra en el organismo, se desarrolla un foco de inflamación exudativa con tendencia a sufrir una caseificación rápida seguida de calcificación, en el órgano diana. Aproximadamente a los 8 días aparecen los primeros focos primarios visibles, formados por un centro necrótico rodeado de un infiltrado inflamatorio granulomatoso de células epitelioides y gigantes, rodeadas por linfocitos. A continuación, los bacilos son transportados rápidamente por la linfa a los ganglios linfáticos regionales ocasionando lesiones similares. A esta lesión que se forma en un principio, caracterizada por afectación del órgano y del nódulo linfático asociado, se le denomina Complejo Primario Completo. A la presencia de estas lesiones también se le conoce por la ley de localización de Cornet. Cuando falta la lesión del órgano y persiste la del nódulo linfático, se denomina Complejo Primario Incompleto.

El foco primario puede desarrollarse en cualquier parte del cuerpo accesible desde el exterior, apareciendo con mayor frecuencia en el aparato respiratorio y el tracto digestivo (faringe o intestino) y con menor probabilidad en la piel, tracto genital y glándula mamaria. En caso de tuberculosis en la placenta, se localiza en el hígado del feto. La frecuencia relativa de este complejo puede variar con la edad. En el vacuno adulto, un 90-95\% de estas lesiones pueden observarse en los pulmones y un 5-10\% en el tracto digestivo. En terneros jóvenes, un $49 \%$ de las lesiones se localizan en hígado, $38 \%$ en pulmón y un $13 \%$ en el tracto digestivo. 


\subsubsection{Periodo post-primario.}

Es una forma de tuberculosis observada con mayor frecuencia en el ganado bovino. Puede desarrollarse de forma endógena por exacerbación de focos del periodo de primoinfección, o de forma exógena por nueva entrada de bacilos. Se caracteriza por tener solo una forma de diseminación, la intracanicular, sus lesiones tienden a sufrir reblandecimiento y no existe lesión ganglionar. Por el modo de diseminación su proceso suele quedar limitado a un órgano o sistema orgánico, siendo el curso de la enfermedad lento pero continuo (tuberculosis orgánica crónica). El reblandecimiento de las lesiones tiene como consecuencia una ruptura precoz hacia los conductos, eliminándose los bacilos al exterior con exudados y secreciones ("tuberculosis abierta"), aunque puede haber encapsulación y cicatrización de lesiones.

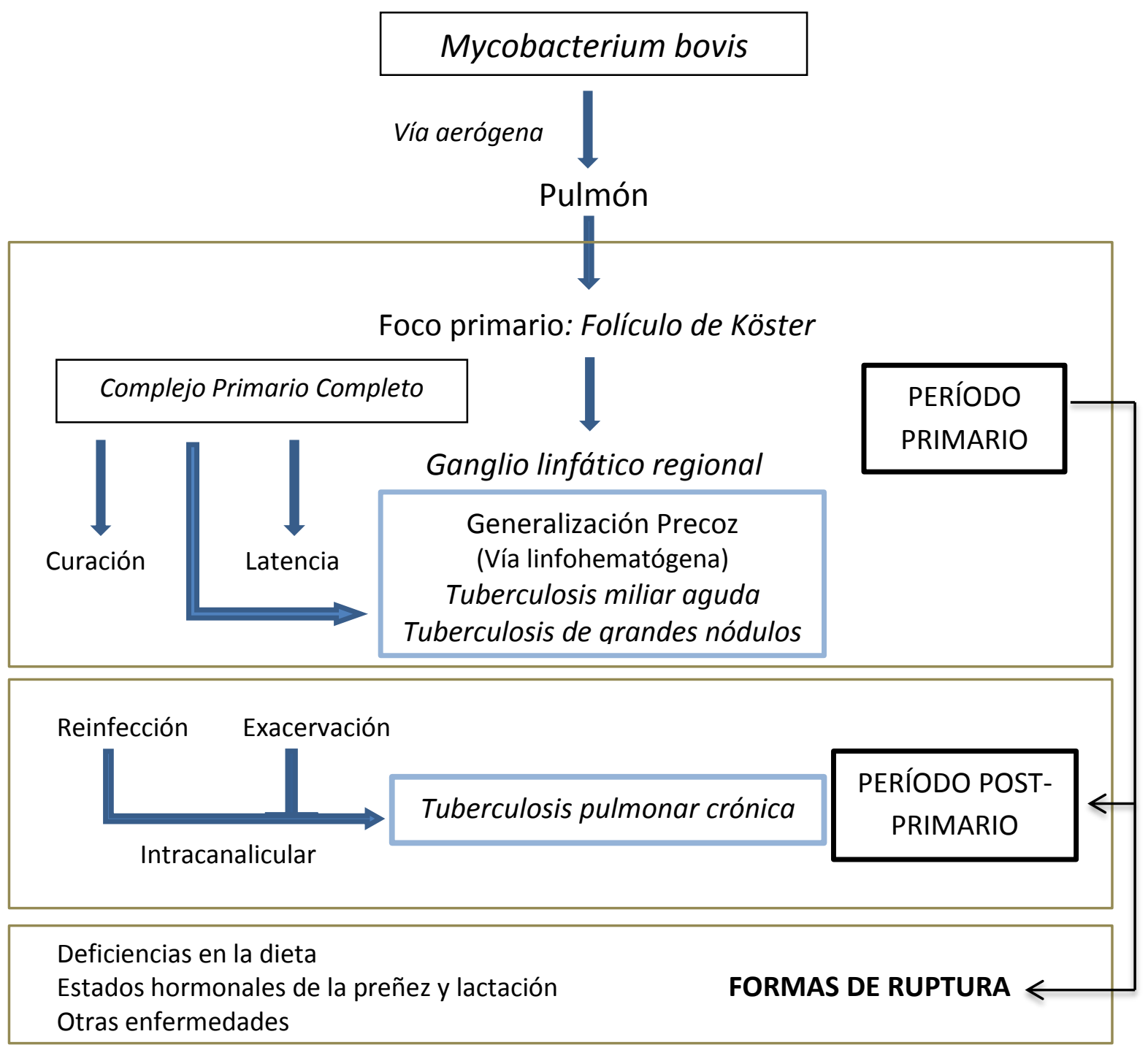

Figura II.1. Etapas de la tuberculosis en el pulmón [García Marín, 1996]. 


\subsubsection{Fase de ruptura.}

Las deficiencias en la dieta, cambios hormonales que suceden en la preñez y lactación así como la coexistencia de otras enfermedades e inmunodeficiencias hacen que la resistencia relativa adquirida durante la Primoinfección y el Período Post-primario puedan fallar. Estas formas tuberculosas estarían encuadradas en los espectros lepromatosos intermedios (border line lepromatous forms) del espectro inmunopatológico de las infecciones por micobacterias. Por lo regular podemos observar la presencia de un gran número de bacilos en los focos caseosos. Los bacilos tuberculosos alcanzan rápidamente la circulación linfática y sanguínea, de tal manera que, cuando la Ley de localización de Cornet se cumple, puede observarse al principio como el ganglio linfático ha sufrido una tumefacción y en pocas horas sufre una necrosis por coagulación o una caseificación primaria y seca con una coloración amarillo-blanquecina, mostrando en la superficie de corte un punteado rojizo (sangre). El paso de bacilos a la corriente sanguínea conduce a una bacteriemia y frecuentemente una generalización (generalización tardía).

Existen factores que determinan el curso de la tuberculosis y su cuadro lesional, es decir, que la inflamación sea preferentemente exudativa o proliferativa, como la: resistencia individual, la especie animal (la caseificación es más común en bovino, porcino y ovino, mientras que en el caprino además de la caseificación se da el reblandecimiento), el tipo de bacilo tuberculoso y el órgano y tejidos implicados [Huchzermeyer et al., 1994].

\subsection{Respuesta inmunitaria.}

En general, la respuesta inmune frente a un agente patógeno puede ser de tipo celular o de tipo humoral; la primera está mediada por células, fundamentalmente macrófagos y linfocitos $\mathrm{T}$, y se va a constituir en la principal respuesta que interviene en la tuberculosis, mientras que la segunda depende de la producción y actuación de anticuerpos. Mycobacterium bovis es un patógeno intracelular que infecta células del sistema inmune del hospedador, principalmente macrófagos [Hernández et al., 2000; Hope et al., 2003; Smith, 2003; Waters et al., 2003; Rivera y Giménez, 2010] que se van a constituir en uno de los tipos celulares claves en la interacción entre el patógeno y el hospedador.

Tras la fagocitosis de $M$. bovis por los macrófagos, se produce una activación de los linfocitos T CD4+ (cooperadores), que secretan diferentes citoquinas (principalmente el interferón-gamma) que actúan favoreciendo la migración de los nuevos macrófagos a partir de los monocitos del torrente sanguíneo hasta el foco de la lesión, donde se produce su proliferación y activación de dichas células permitiendo así la destrucción de las micobacterias fagocitadas [Bendixen et al., 1981; Williams y Williams, 1983; Sevilla, 2007]. 
Después de la activación de los macrófagos puede observarse una serie de transformaciones morfológicas (aumento de tamaño y número de organelas, de enzimas lisosomales y mitocondriales y una mayor adherencia) y bioquímicas (incremento de la actividad respiratoria, del transporte y metabolismo de la glucosa, aumento en la concentración de colesterol en la membrana, mayor producción de peróxido de hidrógeno y superóxidos), utilizados para la destrucción de los microorganismos. Esta mayor capacidad fagocitaria les permite destruir bacilos tuberculosos con mayor eficacia [Ando y Dannenberg, 1972; Edwards y Kirkpatrick, 1986].

Sin embargo, en las fases más avanzadas de la enfermedad, en las que la respuesta inmunitaria de tipo celular ha decaído (principalmente en las formas de ruptura), los macrófagos presentes en las lesiones no mostrarían el mismo grado de activación, siendo incapaces de destruir las micobacterias por lo que estás se multiplican, llegando a desintegrar dichas células, con su posterior liberación para infectar otros macrófagos o bien, diseminarse a través de la linfa o de la sangre a otras parte del cuerpo [Wipple y Palmer, 2000].

Una vez que los macrófagos son activados en el tejido infectado, proliferan y sufren un cambio en su morfología convirtiéndose en células epitelioides, primero inmaduras y luego maduras, denominándose también "macrófagos epitelioides" [Whipple y Palmer, 2000]. Estás células poseen un gran núcleo con cromatina laxa y unos límites celulares muy poco definidos, por lo que cuando se acumulan dan un aspecto de tejido epitelial. En su citoplasma aparece el cuerpo de Schaumann, que es un complejo de sales cristalinas de calcio y cuerpos concoidales, quizás derivado de residuos lisosomales autofagocíticos. Las células epitelioides parecen no poseer función fagocitaria sino más bien productoras de diversas sustancias, como lisozima, mucoglicoproteína, esterasas, $\beta$-galactosidasa, fosfatasas ácidas y enzima convertidora de angiotensina, entre otras [Williams y Williams, 1983; Bernardelli et al., 2002].

Otro tipo de célula de la serie monocítica, con participación en la tuberculosis, es la célula gigante de Langhans, formada por fusión de varios macrófagos para fagocitar las bacterias. Dicha célula, de citoplasma abundante, presenta muchos núcleos, incluso más de doscientos, que están presentes principalmente en la periferia. Su función puede variar según la cepa infectante o la fase de la enfermedad, manteniendo o perdiendo su capacidad fagocítica, pero en cualquier caso conservando siempre la producción de enzimas con capacidad oxidativa (Brodbeck y Anderson, 2009). Una célula similar a esta es la llamada célula gigante de cuerpo extraño, que presenta núcleos distribuidos al azar por el citoplasma. Suele aparecer en las lesiones tuberculosas iniciales, debido al comportamiento de la micobacteria como un cuerpo extraño persistente [Mariano y Spector, 1973]. 
Además de los linfocitos T CD4, se ha comprobado también que la población de linfocitos $\mathrm{T}$ gamma-delta son capaces de reconocer a los antígenos micobacterianos [Haregewoin et al., 1989; Janis et al., 1989; Kabelitz et al., 1990]. Según Janis et al. (1989) los linfocitos $\mathrm{T}$ gamma-delta generan una respuesta inmune primaria frente a las micobacterias tuberculosas, siendo más numerosos que las restantes poblaciones de linfocitos $\mathrm{T}$ en las primeras etapas.

Según se ha señalado en algunos trabajos, los polimorfonucleares neutrófilos no intervienen en la inmunidad protectora contra la tuberculosis [Ridley, 1983]. Sin embargo existen evidencias de su participación activa en la patogenia de la enfermedad. El neutrófilo es la célula principal en las lesiones inflamatorias exudativas de tipo cavernoso que aparecen en el periodo post-primario [Ridley, 1983]. También se ha postulado que los neutrófilos no pueden destruir a Mycobacterium bovis sino que se limitan a eliminar bacilos muertos o fragmentos de los mismos [Pritchard, 1988], sin embargo, Brown et al. (1987) demostraron que los neutrófilos en la especie humana son capaces de destruir $M$. tuberculosis.

\subsection{Signos clínicos y lesiones macroscópicas.}

La tuberculosis generalmente, no presenta manifestaciones y/o signos específicos, por ello el diagnóstico clínico tiene escaso valor, dado que la enfermedad es de curso crónico. El signo clínico más característico es el adelgazamiento progresivo, que puede acompañarse de fiebre fluctuante y que en los estadios más avanzados del proceso llega a terminar en caquexia. En ocasiones, el animal puede presentar tos seca, intermitente y dolorosa con taquipnea y disnea junto con sonidos anormales a la auscultación y percusión. Las lesiones, en ganglios linfáticos y órganos, se caracterizan por la presencia de nódulos o tubérculos con material necrótico caseoso, normalmente calcificado, que va del color blanco hasta un amarillento, cuyo tamaño y cantidad es variable. En el pulmón la lesión, siempre con un componente de necrosis caseosa importante, varía en su morfología según el tipo de neumonía que se observa de acuerdo a las diferentes fases de la patogenia de la tuberculosis.

\subsection{Prevalencia.}

La Organización Mundial de la Salud (OMS) estimo que en 2005 hubo 8,8 millones de nuevos casos de TB, de los cuales 7,4 millones en Asia, África subsahariana y que causó la muerte a 1,6 millones de personas, entre las cuales 195,000 estaban infectadas por el Síndrome de la Inmunodeficiencia Adquirida (VIH) [Araujo et al., 2008]. Así mismo, se estima que entre los años 2002 y 2020 en todo el mundo aproximadamente 1.000 millones de personas se infectarán, más de 150 millones desarrollarán la enfermedad y 36 millones morirán de tuberculosis [NOM-031-ZOO-1995]. 
En México, la tuberculosis humana de origen animal tiene una prevalencia aproximada del 17\%. Como hemos comentado anteriormente, de los 7 mil millones de litros de leche que se producen, aproximadamente entre el 30 y $40 \%$ se consume sin pasterizar y esta podría ser la causa de la elevada prevalencia de la infección [López et al., 2006; Pérez-Guerrero et al., 2008].

La tuberculosis en humanos ocupa en México el lugar número 17 entre las causas de muerte y el primero como causa de muerte por un solo agente infeccioso. De acuerdo con las notificaciones de los casos de tuberculosis, en todas sus formas, remitidas a la Organización Panamericana de la Salud/Organización Mundial de la Salud en 1996, México se encuentra entre los países de América con tasas de incidencia entre 25 y 85/100 000 [Morán et al., 2000].

Se calcula que Mycobacterium bovis es responsable de aproximadamente un 3\% de los casos de tuberculosis humana en el mundo. La infección por Mycobacterium bovis es una zoonosis, con una amplia variedad de hospedadores mamíferos, si bien $M$. bovis es primariamente un patógeno bovino [Zendejas et al., 2007; Prat et al., 2010].

En la inspección post mortem en ganado no procedente de las Campañas de Saneamiento, se han encontrado los siguientes datos de prevalencia:

Un 0,16\% de prevalencia en Uberlandia (Brasil) determinada en el periodo de 1979 a 1983 tras la inspección de 161.437 bovinos [Oliveira et al., 1986]. En Sao Paulo y otros estados brasileños fueron inspeccionados un total de 1.495 .976 vacunos en 1982, presentando tuberculosis en un 0,36\% [Ricetti et al., 1989]. En el periodo de 1984-1996 en el matadero de Triangulo (Brasil) se observó una prevalencia del 0,13\% de un total de 281.326 vacunos sacrificados [Oliveira et al., 1999].

En los Estados Unidos, en 1989 se sacrificaron 33.500.000 bovinos, de los cuales sólo el 0,0004\% tenían lesiones tuberculosas [Ácha y Szyfres, 2001]. En 1995 esta prevalencia alcanzó un 0,05\% cuando se refirió a vacunos procedentes de México [Brown y Hernández de Anda, 1998].

En Baja California, donde anualmente se sacrifican unos 200.000 vacunos, en 1995 y 1996 se obtuvo una incidencia en la inspección post-mortem del 0,12\% y del 0,46\% respectivamente. [Hernández de Anda et al., 1997].

En México, López et al. (1997) realizaron un estudio en 505 decomisos por tuberculosis, donde un $49 \%$ fueron clasificados como micobacteriosis; el $51 \%$ restante fue compatible con otros diagnósticos diferenciales (actinobacilosis, actinomicosis, granuloma eosinofilíco). En seis mataderos de México entre 1996 y 1997 se observaron lesiones 
macroscópicas de tuberculosis en el $16 \%$ de 2.500 vacunos inspeccionados (93\% mayores de 2 años) [Milián Suazo et al., 2000].

\subsection{Control.}

A finales del siglo XIX y a principios del XX se establecieron las primeras medidas de control de la tuberculosis bovina, consistiendo en la eliminación de los animales clínicamente enfermos, pero con particularidades distintas en cada país [Pritchard, 1988]. En 1966 Cuezva Samaniego en España, en base a las experiencias obtenidas en diferentes países para la erradicación de la tuberculosis bovina, estableció las siguientes recomendaciones para un mejor control de la enfermedad: 1) Prueba de la tuberculina intradérmica usando PPD, aislamiento a los animales reaccionantes y sacrificio de los positivos. 2) Estricto control en el tráfico de animales y su comercialización. 3) Prohibición de la aplicación de la vacuna y tratamientos. 4) Comprobar que el personal en contacto con los animales se encuentre libre de tuberculosis. 5) Desinfección tras descubrir una infección. 6) Indemnizar a los propietarios que se propusieran sanear sus establos o que lo hubieran logrado. 7) Aplicación de tratamientos capaces de eliminar en su totalidad todos los bacilos tuberculosos en todos los productos y subproductos de origen animal, tanto para consumo humano como animal.

Las campañas basadas en la aplicación del test de la tuberculina con seguimiento al sacrificio de los reaccionantes positivos ha sido el único que sistema que ha permitido la erradicación de la tuberculosis en muchos países [Radosistis et al., 1994]. Dinamarca fue el primer país en declararse libre de tuberculosis bovina en 1952 y posteriormente fue erradicada en la Polinesia francesa, Somalia, Bermudas, Bahamas, Barbados, Luxemburgo, Hungría, Chipre, Noruega, Finlandia, Isla de Man, Islandia, Suiza e Israel [Pritchard, 1988; Gracey, 1989].

La Comisión Europea a finales del 2003 informó sobre la situación de la tuberculosis bovina en nueve países miembros (Alemania, Australia, Bélgica, Dinamarca, Francia, Finlandia, Luxemburgo, Países Bajos, Noruega y seis provincias de Italia) reconocidos oficialmente como libres de la enfermedad [European Commission. Health and Consumer Protection Directorate General, 2003].

En países en los que no se realiza la prueba de la tuberculina de forma obligatoria, existe un elevado riesgo para la salud pública, por lo que es necesario que se destinen mayores recursos y esfuerzos para erradicar la tuberculosis del ganado [Corner et al., 1991; Pérez-Guerrero et al., 2008]. 


\section{II.3. PARATUBERCULOSIS BOVINA.}

La paratuberculosis o enfermedad de Johne es una enfermedad infecciosa crónica, de los rumiantes que cursa con una enteritis granulomatosa y clínicamente, se caracteriza por la disminución en la capacidad productiva de los animales infectados, inducida por el proceso de mala absorción intestinal, que finalmente conduce a un estado de caquexia [Ábalos, 2001; Tejedor, 2002; Robinson et al., 2008].

Esta enfermedad se describió por vez primera en Alemania a finales del siglo XIX [Johne y Forthingham, 1895]. Estos investigadores observaron bacilos ácido-alcohol resistentes (BAAR) en el intestino de bovinos, e inicialmente creyeron que se trataba de bacilos tuberculosos aviares o bovinos. Bang (1906) fue el primero en admitir que la infección era diferente de la tuberculosis y denominó a la enfermedad enteritis pseudotuberculosa.

\subsection{Etiología.}

El agente causal de la paratuberculosis es Mycobacterium avium sub. paratuberculosis (Map), microorganismo del género de Mycobacterium de crecimiento filamentoso o pseudomiceliar y lento.

El primer aislamiento e identificación de este agente en medio de cultivo se logró en 1911 por Twort e Ingram que lo clasificaron como, una micobacteria denominada Mycobacterium enteritidis chronicae pseudotuberculosae bovis Johne. Posteriormente se conoció al microorganismo como Mycobacterium johnei [Hermon et al., 2000; Chávez, 2005; Kruze et al., 2007; Calderón y Góngora, 2008; Gilardoni y Mundo, 2008].

Fue Bergey et al. (1923) quienes propusieron la denominación de Mycobacterium paratuberculosis, que ha sido el más aceptado durante largo tiempo. En la actualidad se considera al agente causante de la paratuberculosis como una subespecie dentro del complejo Mycobacterium avium, tras la clasificación propuesta por Thorel et al. (1990) empleando criterios genéticos y microbiológicos, que reconoce cuatro grupos dentro de las distintas cepas del complejo Mycobacterium avium:

1.- Formado por cepas de Mycobacterium paratuberculosis y por dos cepas obtenidas de pacientes con enfermedad de Crohn, denominadas Mycobacterium avium subsp. paratuberculosis. Estas cepas cuando se cultivan son dependientes de micobactina, incluso en los subcultivos.

2.- Formado por cepas de Mycobacterium intracellulare y Mycobacterium avium denominadas Mycobacterium avium subsp. avium. 
3.- Formado por cepas de micobacterias aisladas de palomas torcaces denominadas Mycobacterium avium subsp. silvaticum. Estas cepas no crecen en medios de cultivo a base de huevo y su crecimiento se estimula a pH 5.5.

4.- Formado por una única cepa vacunal de Mycobacterium paratuberculosis 316F, aislada en Weybridge (1940), utilizada para la producción de antígenos y vacunas.

Las técnicas de identificación genética son actualmente las más utilizadas para diferenciar las tres principales subespecies del complejo Mycobacterium avium. Están basadas en la detección de secuencias de inserción específicas de cada subespecie: para Map son la IS900, la IS1311 y la ISMav2 [Green et al., 1989; Collins et al., 1990; Whittington et al., 2001b; Strommenger et al., 2001], aunque la primera de ellas no parece ser tan específica como se creía [Cousins et al., 1999; Bölske et al., 2002]

Una de las características metabólicas más importantes de Map a diferencia de las demás micobacterias, tanto del grupo avium como de otros grupos, es su crecimiento extremadamente lento, debido a su elevado tiempo de generación [Juste et al., 2000].

Taylor (1951) ya señaló la existencia de varias cepas de Map, al identificar tres tipos diferentes, según requerimientos y características de cultivo: una cepa bovina que afecta a otras especies, una cepa ovina pigmentada que además parece ser la más virulenta [Stamp y Watt, 1954] y una cepa no pigmentada aislada en ovejas procedentes de Islandia.

Estas diferencias en cultivo fueron investigadas por diferentes autores [Juste et al., 1991; Muskens et al., 2000; Whittington et al., 2001c] comprobando que las cepas de pequeños rumiantes eran más fáciles de cultivar que las cepas bovinas y al contrario que éstas, su crecimiento se veía inhibido por el piruvato sódico [Juste et al., 1991].

En base a pruebas genéticas se han establecido principalmente dos grandes grupos de Map, uno para las cepas ovinas y una cepa caprina aislada en Nueva Zelanda y otro para las cepas bovinas, caprinas y de otros animales [Collins et al., 1990; Bauerfeind et al., 1996; Whittington et al., 2001c; Dohmann et al., 2003]. Desde el punto de vista de la capacidad infectiva, se ha demostrado que algunas cepas de origen caprino tienen poca patogenicidad para el ganado bovino [Saxegaard, 1990]. Sin embargo, esta distinción desde el punto de vista genético a nivel de campo no parece estar muy clara, ya que diferentes autores han encontrado similitudes genéticas entre cepas aisladas de caprino y ovino con otras aisladas a partir de bovino [Muskens et al., 2000; Pillai et al., 2001; Whittington et al., 2001c]. 


\subsection{Epidemiología.}

La paratuberculosis en una enfermedad conocida tradicionalmente por afectar a los rumiantes domésticos, aunque en realidad posee un rango más amplio de hospedadores, ya que se ha confirmado mediante técnicas serológicas, histopatológicas y bacteriológicas en rumiantes salvajes [Chiodini et al., 1984; Blood et al., 1989; Stabel, 1998; Beard et al., 2001a; Kennedy y Benedictus, 2001; Olsen et al., 2002; Stanley et al., 2007; Sánchez et al., 2009] principalmente en ciervos (Cervus elaphus) [Temple et al., 1979; Chiodini y Van Kruiningen, 1983; de Lisle et al., 1993; Fawcett et al., 1995; Stehman, 1996; Nebbia et al., 2000; Pávlik et al., 2000; Mackintosh et al., 2002], bisontes (Bison bison) [Buergelt y Ginn, 2000; Leid et al., 2002; Mackintosh et al.,2002], muflones (Ovis musimon) [Weber et al., 1992; Pávlik et al., 2000], llamas (Lama glama) [Blood et al., 1989; Belknap et al., 1994; Miller et al., 2000; Stanley et al., 2007] y, camellos (Camelus bactrianus) [Paling et al., 1988; Stehman, 1996; Kramsky et al., 2000] entre otros.

El agente causal de la enfermedad también ha sido aislado en varios animales monogástricos como cerdos (Sus scrofa) [Jorgensen, 1969; Larsen et al., 1971; Thoen et al., 1975], conejos (Oryctolagus cuniculus) [Angus, 1990; Daniels et al., 2003a, 2003b; Tiwari et al., 2006; Sevilla, 2007; Bannantine et al., 2008; Merck, 2008], caballos (Equus caballus) [Larsen et al., 1972], lobos (Canis lupus), comadrejas (Mustela nivalis) [Tiwari et al., 2006; Sevilla, 2007; Bannantine et al., 2008; Merck, 2008], liebres (Lepus europacus), tejones (Meles meles), roedores, diferentes tipos de aves [Van Kruiningen et al., 1991; Beard et al., 2001a; Daniels et al., 2003b, 2003c], animales de laboratorio [Hamilton et al., 1991], exceptuando la rata de Lewis [Koets et al., 2000b] y también en el hombre, donde se ha relacionado como posible causa de la enfermedad de Crohn, una enteritis crónica regional propia de la especie humana [Alfaro et al., 2006; Sánchez et al., 2009], lo que adjudicaría a Map un potencial riesgo zoonótico.

Se ha señalado que algunos de estos hospedadores silvestres, como los conejos, podrían jugar un papel importante en la transmisión de la infección a los rumiantes domésticos en algunas regiones, ya que pueden liberar en sus heces millones de Map/hectárea y los rumiantes domésticos contagiarse cuando pastan o comen alimentos contaminados con Map [Greig et al., 1999; Daniels et al., 2001; 2003a, 2003b, 2003c].

Un estudio realizado en Grecia por Florou et al. (2008) concluyó que la cepa de Map más frecuente en rebaños ovinos y caprinos infectados de paratuberculosis, coincidía con aquella aislada en cuatro especies salvajes monogástricas diferentes que coexistían con estos rebaños (ratas, ratones, zorros y liebres). Asimismo, mediante técnicas moleculares, se han identificado los mismos genotipos de Map entre diferentes hospedadores silvestres y domésticos que convivían en el mismo hábitat, apoyando la teoría de transmisión interespecie [Stevenson et al., 2009]. 
Sin embargo, Whittington et al. (2001a) empleando técnicas moleculares demostraron que las cepas que infectaban al ganado bovino y a los bisontes eran diferentes. Por ello se requieren más estudios para estimar el impacto y riesgo epidemiológico real que estas especies, animales silvestres suponen para el ganado ovino, caprino y bovino [Kennedy y Benedictus, 2001; Florou et al., 2008].

\subsection{Patogenia.}

Los animales jóvenes, menores de un año son los más susceptibles de infectarse con Map y el contagio se produce principalmente por la vía digestiva, al mamar de ubres contaminadas con heces de animales excretores [Julián, 1975; Chiodini, et al., 1984; Blood et al., 1989; Juste y Adúriz, 1990b; García Marín et al., 2000; Bernardelli et al., 2002; Raizman et al., 2004; Jorge et al., 2005; Alfaro et al., 2006; Wells et al., 2006; Bannantine et al., 2008; Griffiths et al., 2008; Merck, 2008].

Existen otras vías, aunque de menor importancia, como el calostro [Streeter et al., 1995; Millar et al., 1996] el agua, alimento y, diversas superficies contaminadas a las que los animales tienen acceso [Taylor, 1951; Cocito et al., 1994; Swenney, 1996; Stabel, 1998; Hansen y Rossitier, 1999; Gerlach, 2002; Mura et al., 2006; Tiwari et al., 2006].

Se ha propuesto la vía transuterina como una forma de contagio, debido a que se ha asilado Map en vacas infectadas con y sin signos clínicos, a partir de cotiledones y, mucosa del útero [Doyle, 1954; Pearson y McCelland, 1955; Lawrence, 1956], de fetos [Pearson y McClleland, 1955; Merkal, 1984b; Seitz et al., 1989; Sweeney et al., 1992], pero de forma muy ocasional y sin importancia en la práctica [Reddy et al., 1984; Rebhun, 1995]. También se ha aislado del tracto genital y del semen de toros, aunque la infección por esta vía no se ha demostrado [Larsen et al., 1981; Eppleston y Whittington, 2001; Chávez, 2005].

Igualmente se ha constatado la participación de vectores en presencia de la enfermedad, huevos de tricoestróngilos, diferente lombrices de tierra (ninfas de cucaracha) y diversas especies de moscas [Whittington et al., 2001a; Fisher et al., 2001; 2003a, b; 2004; Sevilla, 2007] que han estado en contacto con heces contaminadas con la micobacteria.

Estudios experimentales realizados en bovinos, indican que una vez ingerida la micobacteria patógena y después de haber atravesado la barrera intestinal por endocitosis, las primeras lesiones de la paratuberculosis aparecen en la placa de Peyer ileal [Momotami et al., 1988; Lugton, 1999]. 
El tejido linfoide juega un papel muy importante en la infección por Map, lo cual podría explicar el alto porcentaje de susceptibilidad en los animales jóvenes. En este sentido, la placa de Peyer representa alrededor del 90\% del tejido linfoide intestinal en los corderos al nacimiento, involucionando a las 12 semanas de vida y regresando casi en su totalidad entre los 15 y 18 meses de vida, lo que limitaría la implantación del microorganismo [Reynolds y Morris, 1983].

La entrada de Map en el tejido linfoide intestinal se produce a través de las células M situadas en el epitelio de revestimiento de las cúpulas de la placa de Peyer, las cuales degradan y presentan la micobacteria con otras células del sistema inmune en asociación con los linfocitos T del área parafolicular [Momotami et al., 1988; García Marín et al., 1992a; Snider et al., 1992; Fujimura y Owen, 1996; Lugton, 1999; Sigurdardóttir et al., 2001; Stabel et al., 2007; Zapata et al., 2008].

Las células $\mathrm{M}$ transportan las micobacterias de forma transcelular de forma que son captadas por macrófagos intraepiteliales o subepiteliales de la lámina propia adyacente a la placa de Peyer, donde se sitúan en fagosomas [Chiodini et al., 1984; Momotami et al., 1988; Kaufmann, 1995; Fujimura y Owen, 1996; Lugton, 1999; Valentin-Weigand y Goethe, 1999; Tessema et al., 2001; Sigurdardóttir et al., 2001] llegando a sobrevivir allí hasta 15 días [Kuehnel et al., 2001].

Estos macrófagos son considerados células blanco en la infección paratuberculosa [Kaufmann, 1995]. No está suficientemente aclarado como sobrevive Map dentro de los macrófagos, pero lo cierto es que puede resistir los diversos mecanismos antimicrobianos de estas células, tales como la fusión fagosoma-lisosoma, mecanismos oxidativos, enzimas lisosómicas y producción de óxido nítrico [Harris y Barletta, 2001] o producir el bloqueo de la acidificación fagosómica inhibiendo así la maduración de los fagosomas a fagolisosomas funcionales lo que favorece su replicación en las vacuolas bacterióforas [Cheville et al., 2001; Hostetter et al., 2002].

Como consecuencia de la respuesta inmunológica que ofrece el hospedador, puede ocurrir que los macrófagos destruyan a la micobacteria y el animal supere la infección, o que la micobacteria sobreviva y el animal desarrolle la enfermedad clínica o bien permanezca como portador asintomático de la infección durante largos periodos, pudiendo excretar Map [Rankin, 1961; Gilmour et al., 1978; Fodstad y Gunnarsson, 1979; Thomas, 1983; Blood et al., 1989; Snider et al., 1992; Barker et al., 1993; Clarke, 1997; Storset et al., 2001]. La evolución hacia un estado u otro depende de diversos factores que se reflejan a continuación:

*Patogenicidad de las cepas de Map, tanto intraespecífica como interespecífica [Stamp y Watt, 1954; Saxegaard, 1990]. 
* Tiempo de exposición de la bacteria y la dosis recibida [Clarke y Little, 1996; Sweeney, 1996; Whithlock y Buergelt, 1996; Bannantine y Stabel, 2002].

*La respuesta del hospedador [García Marín et al., 1994; Clarke, 1997] influida por factores como: la especie del rumiante afectada [Stabel et al., 2003] y susceptibilidad genética [Koets et al., 2000a], la edad [Doyle y Spears, 1951; Larsen et al., 1975; Clarke, 1994; Cocito et al., 1994; Whithlock y Buergelt, 1996].

*Estado nutricional y dieta [Doyle y Spears, 1951; Snider et al., 1992; Harris y Barletta, 2001; Stabel et al., 2003].

*Condiciones de estrés, y cambios hormonales como el parto y la lactación [Reddy et al., 1984; Kreeger, 1991; García Marín et al., 1994; Rebhun, 1995]. Estudios realizados "in vitro" muestran que la hormona del crecimiento y la prolactina afectan la capacidad de los monocitos sanguíneos de los bovinos para fagocitar y destruir a Map [Feola et al., 1999].

*Estado inmunológico, que determina la capacidad del animal para que la infección progrese. [Gilmour et al., 1978; Clarke et al., 1996].

\subsection{Signos clínicos.}

Los animales pueden infectarse en las primeras semanas de vida, pero debido al carácter crónico de la paratuberculosis, estos no empiezan a manifestar signos clínicos hasta la edad adulta, tras un largo periodo de incubación. Los síntomas no se observan antes de 2 años, frecuentemente tras el parto, durante la primera o segunda lactación, si bien pueden padecerla también animales mayores. Sin embargo, la paratuberculosis clínica es muy rara en animales menores de 1,5 años [Chiodini et al., 1984; Sherman, 1985; Blood et al., 1989; Barker et al., 1993; García Marín et al., 1994; Stabel, 1998; Pávlik et al., 2000; Pérez et al., 2000; Coromoto et al., 2006], aunque a partir de los 11 meses de edad pueden convertirse en excretores [Kalis et al., 1999].

La paratuberculosis es una enfermedad caquectizante ya que su signo clásico más característico es la pérdida progresiva de peso y de la condición corporal dando como resultado un adelgazamiento crónico en todas las especies, a pesar de recibir los animales una alimentación adecuada y de no tener pérdida del apetito [Aller et al., 1973; García Marín et al., 1994; Pávlik et al., 2000; Pérez et al., 2000; González et al., 2005; Pradenas et $a l ., 2008]$. La mala absorción y la pérdida de proteínas asociadas a la inflamación del intestino son la principal causa de la pérdida de peso [Allen et al., 1974] si bien las manifestaciones pueden ser diferentes de acuerdo a la especie afectada. Un signo clínico asociado a la hipoproteinemia es el edema en las partes declives, siendo el más típico el 
edema submandibular que tiende a desaparecer cuando se desarrolla la diarrea [Chiodini et al., 1984; Whitlock y Buergelt, 1996].

En el ganado bovino la pérdida de peso frecuentemente se acompaña de diarrea crónica o intermitente, no sanguinolenta, en ocasiones maloliente, que no responde eficazmente a tratamientos con antibióticos o con algún cambio en la alimentación [Chiodini et al., 1984; Sherman, 1985; Blood et al., 1989; Barker et al., 1993; Corpa et al., 1998a; Hansen y Rossitier, 1999; Pérez et al., 2000; Ábalos, 2001]. Este signo clínico puede durar varias semanas o incluso en meses, con periodos de recuperación transitoria [Juste et al., 1983; Pérez et al., 2000].

Además de la diarrea y caquexia en el ganado vacuno lechero de alta producción pueden observarse otros síntomas más inespecíficos: disminución en la producción láctea que va del 5 al $25 \%$ y ocasionalmente, alteraciones en la fertilidad, además de una mayor susceptibilidad a padecer problemas de mastitis. [Sherman, 1985; Adúriz et al., 1994; Corpa et al., 1998a; Stabel, 1998; Valentine-Weigand y Goethe, 1999; Pérez et al., 2000; Stabel et al., 2007; Yakes et al., 2008; Raizman et al., 2009; Sánchez et al., 2009]. En ocasiones, estas alteraciones son las únicas que se presentan, el bajo rendimiento productivo, la pérdida de peso o las diarreas intermitentes, que normalmente el ganadero o veterinario confunden con problemas de tipo digestivo no infeccioso suelen ser la causa de la eliminación de los animales de la explotación [Badiola et al., 1979; Sherman, 1985; Rebhun, 1995; Withlock y Buergelt, 1996; Clarke, 1997; Pérez et al., 2000; Calderón y Góngora, 2008; Yakes et al., 2008].

Después de haberse iniciado el proceso clínico, la mortalidad alcanza un 100\%, aunque en ocasiones, la disminución de producción láctea, pérdida de peso y diarrea, pueden conducir a un secado prematuro del animal permitiéndole la recuperación parcial hasta la siguiente lactación [Pérez et al., 2000].

\subsubsection{Lesiones macroscópicas.}

Los primeros hallazgos observados en la necropsia de un animal clínicamente afectado por paratuberculosis son: caquexia, atrofia muscular, pérdida de la grasa mesentérica y de los surcos coronarios que se remplaza por tejido gelatinoso (atrofia serosa), y presencia de edemas en tejido subcutáneo de zonas declives, destacando el edema submandibular y la efusión de líquidos serosos en diferentes cavidades corporales en forma de ascitis o hidropericardias. [Pérez et al., 2000; Ábalos, 2001; Tejedor, 2002; Berger et al., 2006].

Las lesiones características específicas de esta enfermedad se localizan en el intestino delgado y nódulos linfáticos regionales [Badiola et al., 1979; García Marín et al., 
1994; Pérez et al., 2000; Ayele et al., 2001; Bernardelli et al., 2002; Berger et al., 2006; Brown et al., 2007; Jaimes et al., 2008].

Aparecen principalmente en los tramos finales del intestino delgado, pudiéndose observar un marcado engrosamiento de la pared, principalmente en la válvula ileocecal, íleon y las porciones más distales del yeyuno, dando una apariencia de "tubo de goma". En ocasiones también puede estar afectado el ciego y los primeros tramos del colon. En casos más avanzados las lesiones pueden extenderse de forma difusa desde el duodeno hasta el recto. Al abrir los tramos alterados, la mucosa y submucosa presentan un aspecto tumefacto y edematoso, están muy engrosadas y muestran pliegues que recuerdan a las circunvoluciones del cerebro, que no desaparecen al estirar el intestino, y, en ocasiones, sus ápices aparecen congestivos, con múltiples petequias e incluso pequeñas erosiones, en contraste con el resto de la pared intestinal, que muchas veces presenta una coloración pálida [Hutyra y Marek, 1930; Buergelt et al., 1978; Badiola et al., 1979; Juste et al., 1983; Carrigan y Seaman, 1990; Corpa et al., 1998a; Pérez et al., 2000; Bernardelli et al., 2002; Berger et al., 2006; Brown et al., 2007; Sevilla, 2007; Jaimes et al., 2008].

Acompañando al engrosamiento de la pared intestinal se observa linfangiectasia y linfangitis en la serosa, de forma que los vasos linfáticos a menudo aparecen como cordones blanquecinos o transparentes, visible en la serosa intestinal y mesenterio en animales con caquexia extrema. En algunos casos no son tan evidentes, y solo pueden observarse de manera focal poco aparente, principalmente en ovinos y caprinos, y con menor frecuencia en bovinos [Barker et al., 1993; Pérez et al., 2000; González, 2003; Kurade et al., 2004; Brown et al., 2007].

Por su parte, los nódulos linfáticos mesentéricos, principalmente los yeyunales e ileocecales, aparecen aumentados de tamaño, tumefactos y edematosos. Al corte presentan una coloración muy pálida, llegando a ser prácticamente indistinguible la zona medular de la cortical, otras veces, la medular puede adquirir un color marronáceo-verduzco [Buergelt et al., 1978; Chiodini et al., 1984; Blood et al., 1989; Carrigan y Seaman, 1990; Barker et al., 1993; Corpa et al., 1998a, 2000; González et al., 2003; Brown et al., 2007].

En bovinos con paratuberculosis clínica muy avanzada se ha descrito la formación de focos de mineralización y fibrosis en las paredes arteriales, principalmente en aorta, arteria mesentérica, así como en endocardio, dando un aspecto macroscópico de placa rugosa blanquecina [Chiodini et al., 1984; Blood et al., 1989; Corpa et al., 1998a; Pérez et al., 2000; González, 2003; Brown et al., 2007]. 


\subsubsection{Lesiones microscópicas.}

Microscópicamente la paratuberculosis se caracteriza por una enteritis y linfadenitis de tipo granulomatoso. En la lámina propia, se observa un infiltrado focal o difuso de linfocitos, gran cantidad de macrófagos homogéneos y células epiteloides que se agrupan formando los granulomas característicos de esta enfermedad [Stamp y Watt, 1954; Rayja y Singh, 1961; Buergelt et al., 1978; Badiola et al., 1979; Barker et al., 1993; García Marín et al., 1994; Pérez et al., 1996; Corpa et al., 2000; Pérez et al., 2000; Chávez, 2005; Brown et al., 2007; Slana et al., 2008].

Histológicamente, los animales con la forma clínica de la enfermedad muestran lesiones graves difusas, principalmente de tipo multibacilar, con abundantes BAAR en válvula ileocecal, íleon y yeyuno, que se pueden extender en ocasiones a diferentes tramos de intestino grueso, principalmente en ciego y colon, siendo más esporádica la presencia de alteraciones de duodeno y recto. Además, pueden encontrarse células gigantes multinucleadas de Langhans, observadas con mayor frecuencia en el ganado bovino, aunque también pueden aparecer otros tipos celulares como linfocitos, células plasmáticas y eosinófilos [Buergelt et al., 1978; Carrigan y Seaman, 1990; Peris, 1992; García Marín et al., 1992c; Pérez et al., 1996; Corpa et al., 2000; Pérez et al., 2000; Ábalos, 2001; Tiwari et al., 2006; Brady et al., 2008; Liying et al., 2008].

En casos más graves el exudado inflamatorio se extiende por las vellosidades intestinales, por lo que se observan dilatadas y deformadas, incluso atróficas, llegando a desplazar y obliterar las criptas de Lieberkhün, por la presencia de abundante material necrótico y células inflamatorias en su interior [Badiola et al., 1979; Pérez et al., 1996; Corpa et al., 1998a, 2000; Pérez et al., 2000; González et al., 2005; Brown et al., 2007].

En cuanto a lesiones extra-intestinales asociadas a paratuberculosis, en casos clínicos avanzados y graves, puede observar la, degeneración y fibrosis con depósito de sales de calcio en la capa íntima y media de la arteria aorta y endocardio descritas en bovino [Simpson, 1966; Buergelt et al., 1978; Clarke y Little, 1996; Corpa et al., 1998a; González, 2003; Brown et al., 2007]. También se han descrito granulomas multifocales en el hígado con, presencia de bacilos ácido-alcohol resistentes [Harding, 1957; Buergelt et al., 1978; Chiodini et al., 1984; Carrigan y Seaman, 1990; González, 2003]. Con menos frecuencia se han señalado lesiones granulomatosas focales en los riñones, pulmones y nódulos linfáticos regionales [Hines et al., 1987; Clarke y Little, 1996; Sevilla, 2007].

Teniendo en cuenta la variabilidad de las lesiones paratuberculosas en las distintas especies de rumiantes domésticos, se han propuesto diversas clasificaciones de las mismas, atendiendo a la gravedad y, extensión, tipos celulares implicados y la cantidad de 
micobacterias presentes en las lesiones. [Clarke y Little, 1996; Pérez et al., 1996; Coetsier et al., 1998; Brumbaugh et al., 2000; Corpa et al., 2000; González et al., 2005].

En ganado bovino, destacan los trabajos realizados por Buergelt et al. (1978) y por González (2003). Los primeros, realizaron un estudio en 51 animales desechados de dos rebaños infectados con paratuberculosis, tomando muestras de duodeno, yeyuno, íleon, válvula ileocecal, ciego, colon, recto y nódulos linfáticos mesentéricos e ileocecales, clasificando las lesiones en leves, moderadas y graves, en base a los tipos celulares y a la presencia de BAAR.

-Lesiones leves o de tipo I: Caracterizadas por la presencia de células gigantes de Langhans en la lámina propia de las vellosidades intestinales o dispersas en la paracortical de los nódulos linfáticos, apareciendo pocas células epitelioides con escasa o nula presencia de BAAR.

-Lesiones moderadas o de tipo II: Caracterizadas por la presencia de pequeños grupos de macrófagos con varias células gigantes de Langhans en la lámina propia y submucosa, en senos subcapsulares o paracortical de los nódulos linfáticos regionales, con cantidad de BAAR variable, nula o moderada.

-Lesiones graves o de tipo III: Presentan un infiltrado inflamatorio compuesto por un gran número de macrófagos y células gigantes de Langhans en todas las capas de varios tramos del intestino delgado, afectando a la mucosa, submucosa, muscular y serosa, alterando la estructura histológica normal de las vellosidades intestinales. Así mismo, se observa una dilatación de las criptas de Lieberkhün. También se afectan gravemente los nódulos mesentéricos, donde el infiltrado de macrófagos y células gigantes en los senos subcapsulares y en la paracortical, llega a reemplazar a los folículos linfoides. Los macrófagos contienen abundantes BAAR.

González et al., (2005), realizan una nueva clasificación a partir de los resultados obtenidos en 116 animales infectados con y sin signos clínicos, siguiendo los criterios propuestos por Pérez et al. (1996) en los que también se incluyen animales con infección subclínica.

Estos autores distinguen tres tipos principales de lesiones: focales, multifocales y difusas, similares a los descritos para la especie ovina [Pérez et al., 1996] con las siguientes particularidades:

*Lesiones focales.- En esta especie, es frecuente la aparición de alguna célula gigante asociada a los granulomas o asiladas principalmente en el tejido linfoide ileocecal, tal y 
como han descrito otros autores [Payne y Rankin, 1961a, 1961b; Gilmour et al., 1965] en infecciones experimentales en ganado bovino.

*Lesiones multifocales.- Este tipo de lesiones se caracterizan por la presencia de pequeños granulomas o de células gigantes de Langhans, asociadas a los granulomas o aisladas, sin producir alteración morfológica de las vellosidades intestinales, aunque en ocasiones puede existir un ligero engrosamiento de la pared intestinal en algún tramo. Estas lesiones aparecen tanto en la mucosa, como en los espacios interfoliculares de la placa de Peyer y/o de los nódulos linfáticos ileales o yeyunales, siendo mayores, en tamaño y número que las lesiones focales. Los BAAR pueden observarse en cantidades variables.

*Lesiones difusas.- En este caso, la diferencia con la clasificación en ovinos radica en la aparición de un subtipo de lesiones intermedias, semejantes a las descritas por Kheirandish et al. (2008). Las lesiones halladas frecuentemente en el estudio de González et al. (2005), fueron lesiones difusas que compartían características con las formas multibacilares y linfocíticas, por lo que se considera como un subtipo mixto. En ellas el infiltrado es una mezcla de linfocitos, células plasmáticas, macrófagos formando pequeños granulomas, así como células gigantes en número variable. Este infiltrado altera la estructura histológica normal de la mucosa intestinal y puede diseminarse hacia la submucosa en los casos más graves, donde aparece rodeando vasos a veces con trombos. La serosa presenta una linfangitis y serositis marcada, con distintos niveles de gravedad dependiendo del tramo en que se localice. Los nódulos linfáticos también se encuentran afectados, principalmente el mesentérico caudal. En este tipo de lesiones se detecta un número elevado de BAAR mediante $\mathrm{ZN}$ o tinción inmunohistoquímica, aunque siempre en cantidad inferior a las formas multibacilares.

\subsection{Prevalencia.}

La paratuberculosis es una enfermedad de creciente prevalencia en animales de abasto, de distribución mundial y es, considerada como una de las enfermedades emergentes más importantes [Chávez, 2005; Kruze et al., 2007] que causan graves pérdidas económicas [López et al., 2006]. Aunque el estudio de la prevalencia de la infección por Map se ve limitado por la eficacia de las técnicas diagnósticas y el largo período de la latencia de la infección [Sevilla, 2007], se ha señalado que la prevalencia es mayor en bovinos de producción lechera en régimen intensivo. [Boelaert et al., 2008].

Se han utilizado deferentes métodos para determinar la prevalencia de la paratuberculosis, principalmente usando métodos bacteriológicos y serológicos. El cultivo ha sido el método bacteriológico más utilizado, pero también se emplean, aunque en menor medida, técnicas moleculares como la PCR. En 1969 Jorgensen y posteriormente en 1972, determinó una tasa de infección a partir del cultivo de ganglios linfáticos mesentéricos de 
animales sacrificados en Dinamarca, de un 2,3\% y de un 9,8\% respectivamente. Utilizando esta misma técnica, a partir de muestras de hígado, tonsilas, colon, íleon, válvula ileocecal y ganglio linfático ileocecal, se obtuvo una positividad del $18 \%$ en vacuno tomado al azar sacrificado en mataderos de Nueva Inglaterra [Chiodini y Van Kruiningen, 1986]. Por otra parte, en 1987 Merkal y su grupo colaborador, obtuvieron una prevalencia del 1,6\% en ganglios linfáticos ileocecales de ganado vacuno sin sintomatología clínica de paratuberculosis sacrificados en diferentes mataderos de Estados Unidos.

Los estudios realizados para determinar la prevalencia de la paratuberculosis en los rebaños, mediante cultivo fecal, indicaron que, en Illinois el 35\% [McPherron et al., 1983], en Gran Bretaña el 20\% [Rankin, 1962] y en Dinamarca el 4\% [Jorgensen, 1972] de las granjas estaban infectadas.

En España, la primera descripción de la paratuberculosis fue en 1915 [Ferreras, 1915] y posteriormente en 1935 [Roca Soler, 1935], aunque la confirmación de una infección por Map en ganado bovino, data de 1983 en un rebaño de raza Charoláis en el País Vasco [Juste et al., 1983]. Un estudio realizado sobre 134 animales sacrificados en mataderos de Asturias, reveló una prevalencia del 28,35\% mediante histopatología, inmunohistoquímica y PCR de la válvula ileocecal, ganglio linfático ileocecal y yeyunal caudal [Balseiro et al., 2003]. En lo que se refiere a la prevalencia intrarebaño de la infección, existen muy pocos estudios publicados al respecto. Destaca el realizado por González (2003), sobre 3 rebaños positivos a paratuberculosis. En el mismo, se obtuvieron prevalencias que oscilaban entre un $12 \%$ y un $27 \%$.

En México esta enfermedad es poco conocida y sería necesaria su consideración en el ganado importado de países de Europa, EEUU, Canadá, Nueva Zelanda y Australia [Esteves-Denaives et al., 2007].

\subsection{Control.}

Además de poner en práctica los diferentes programas de control, es recomendable llevar a cabo un manejo correcto y mantener buenas medidas higiénico-sanitarias, para disminuir la propagación de la enfermedad en los animales. La limpieza y desinfección periódica juegan un papel importante en el control de la enfermedad, así como, la eliminación y el aislamiento de los animales con sintomatología clínica [Juste et al., 1990a; Juste y Sáez de Ocariz, 1990; Adúriz et al., 2000; Kalis et al., 2001; Beyerbach et al., 2001; Gerlach, 2002; Muskens et al., 2003; Gruenendaal et al., 2003]. Además, es de suma importancia evitar la entrada y salida de animales incontrolados, por lo que se recomienda realizar pruebas de diagnóstico a los mismos para asegurar que están libres de la enfermedad [Adúriz et al., 2000]. 
La mayoría de los programas de control tienen como principales objetivos [Kennedy et al., 2001]: 1) reducir las pérdidas económicas, 2) proteger a los rebaños no infectados o de bajo riesgo, 3) mejorar las condiciones de los rebaños infectados, 4) disminuir la excreción de Map en el medio ambiente, 5) romper la cadena de transmisión en los animales recién nacidos, y 6) disminuir el riesgo de Map en los productos animales.

\subsubsection{Vacunación.}

Las primeras vacunaciones frente a la paratuberculosis bovina se llevaron a cabo en 1926 en Francia con una cepa atenuada [Vallee y Rinjard, 1926]. Desde entonces se han usado una gran variedad de vacunas con aislados de Map vivos atenuados o no atenuados [Hagan, 1936; Gilmour y Brotherston, 1966; Larsen et al., 1974], inactivadas térmicamente [Larsen et al., 1978; Brotherston et al., 1961] o con fragmentos de Map [Gilmour y Brotherston, 1966; Larsen et al., 1969; Larsen et al., 1978]. La cepa de Map que más se emplea para la preparación de vacunas es la 316 F (Central Veterinary Laboratory, Weybridge, Inglaterra), aunque se han empleado otras como la cepa 18, cepa 5889 de Bergey, un aislado del Instituto de Lelystad (Holanda) y aislados de campo [Harris y Barletta, 2001]. Actualmente existen vacunas comerciales vivas como es el caso de NeoparasecTM (MERIAL, New Zealand Ltd., Nueva Zelanda) e inactivadas como es la vacuna de Gudair® (CZ Veterinaria S.A., Pontevedra, España).

En cuanto a la vía de inoculación, la más utilizada es la administración subcutánea durante el primer mes de vida para proteger al animal antes de que se produzca la infección o impedir la progresión de la misma si el animal ya está infectado [Larsen, 1964]. Sin embargo, Corpa et al. (1998a) indicaron que tanto la respuesta inmune humoral como la celular, inducidas con la vacuna de Gudair en los pequeños rumiantes, son más intensas, rápidas y persistentes cuando se realizan a los 4-5 meses de edad [Corpa et al., 1998b]. Una dosis ofrece suficiente inmunidad y no es necesaria una segunda dosis vacunal ya que se ha demostrado que incluso puede provocar una disminución en la protección adquirida [Gilmour, 1976; Bendixen, 1978; Stuart, 1965].

\section{II.4. DIAGNÓSTICO DE LAS MICOBACTERIAS.}

Uno de las principales dificultades que existen en el diagnóstico de las enfermedades causadas por micobacterias se debe a la falta de técnicas con una especificidad y sensibilidad del 100\%, siendo especialmente complicada la detección de animales con infección subclínica o portadores latentes, con el posible riesgo de obtener resultados falsos-positivos o falsos-negativos [Kregger, 1991; Withlock, 1998; Kalis et al., 1999; Garrido et al., 2000; Olsen et al., 2002; Soto et al., 2002; Collins, 2004]. 
Un método diagnóstico "ideal" tendría que ser: rápido, barato y la sensibilidad y especificidad suficiente para distinguir a los animales que están excretando micobacterias, para evitar focos de infección para el resto de los animales [Merkal, 1984; Olsen et al., 2002; Arcelles et al., 2005]. En la actualidad todos los métodos existentes para el diagnóstico de la enfermedad por micobacterias, tanto en animales vivos como en cadáveres se clasifican en cuatro grupos: los basados en aspectos clínicos y epidemiológicos, los que reconocen de manifestaciones lesionales, los que detectan al agente etiológico y los basados en la respuesta inmune que desarrollan los animales infectados [Garrido et al., 2000; Ábalos y Retamal, 2004].

\subsection{Diagnóstico clínico y epidemiológico.}

La presencia de paratuberculosis y tuberculosis en una explotación se puede sospechar normalmente cuando aparecen signos clínicos [García Marín et al., 1994; Hansen y Rossitier, 1999; Pávlik et al., 1999; Pérez et al., 2000; González, 2003]. A lo largo de todo el año, pero más frecuentemente cuando los animales están sometidos a condiciones climatológicas más adversas (invierno), situaciones de estrés (parto), se observa entre un 1$10 \%$ de bajas por goteo de animales con signos clínicos [García Marín et al., 1994; Pávlik et al., 1999; Singh y Singh, 2000].

El diagnóstico de la enfermedad subclínica es más complicado; puede observarse una caída en la producción láctea, problemas reproductivos como infertilidad y mastitis [Merkal, et al., 1975; Chiodini, et al., 1984; Goodger et al., 1996; Nordlund et al., 1996; Corpa et al., 1998a; Valentin-Weigand y Goethe, 1999; Pérez et al., 2000; Losinger, 2005; Raizman et al., 2009]. Hay autores que señalan que la enfermedad puede detectarse por la disminución de tamaño de las masas musculares glúteas y femorales, y por la presencia de un edema intermitente en la mandíbula meses antes de la aparición de cualquier otro signo clínico [Hutchinson, 1996]. Se ha sugerido que un análisis de las proteínas y de los minerales séricos puede resultar muy útil en el diagnóstico de la paratuberculosis en animales caquécticos [Scott et al., 1995; Jones y Kay, 1996] Debido al carácter inespecífico de los síntomas el diagnóstico debe confirmarse mediante otras técnicas [Dunkin, 1934; Smyth y Chiristie, 1950; Merkal, 1973; Sherman, 1985; Juste y Adúriz, 1990b; Pérez et al., 2000; Cicuta et al., 2003].

Sin embargo, en el diagnóstico clínico debe diferenciarse de otros procesos crónicos caquectizantes o debilitantes como son, la malnutrición, deficiencias de minerales u oligoelementos, problemas parasitarios, abscesos internos y enfermedades hepáticas o renales o bien de otros procesos que cursan con diarrea en animales adultos como son salmonelosis, desplazamiento recurrente de cuajar, coccidiosis o parasitosis y, BVD entre otros [Stamp y Watt, 1954; Seaman et al., 1981; Sherman, 1985; Kimberling, 1988; Blood 
et al., 1989; Green et al., 1989; Carrigan y Seaman, 1990; Ott et al., 1999; Garrido et al., 2000].

La sintomatología clínica de la tuberculosis varía con la distribución de las lesiones en el organismo, suele presentar una evolución dilatada en el tiempo y los síntomas pueden tardar meses o años en aparecer. Los signos clínicos varían en función de la localización de las lesiones. En el caso de hallarse en el pulmón se manifiesta con tos seca intermitente que podría estar inducida por cambios de temperatura o la presión en la tráquea, así como neumonía. En estados avanzados de la enfermedad existe engrosamiento de los ganglios linfáticos que podrían obstruir el paso del aire, el tracto alimentario u oprimir los vasos sanguíneos. Otros síntomas habituales son la debilidad, pérdida de apetito y de peso, fiebre fluctuante, tos seca intermitente, diarrea y ganglios linfáticos grandes y prominentes. [Vestal, 1975; Cuezva-Samaniego, 1966].

\subsection{Diagnóstico anatomopatológico.}

El estudio macroscópico de tejidos procedentes de animales afectados clínicamente por tuberculosis i paratuberculosis muestra una elevada fiabilidad y especificidad alta en el diagnóstico de la enfermedad, aunque debe tenerse en cuenta que las lesiones no siempre son evidentes, principalmente cuando se trata de formas subclínicas e incluso algunas clínicas [Buergelt et al., 1978; Clarke y Little, 1996; Pérez et al., 1996; Clarke, 1997; Corpa, 1999; Brady et al., 2008]. Este diagnóstico presenta una desventaja importante y es el hecho de que debe llevarse a cabo principalmente en animales muertos, no obstante, tiene un gran valor en la inspección post-mortem [Garrido et al., 2000; Escobar et al., 2003; González, 2003].

\subsubsection{Técnicas histopatológicas.}

Las técnicas histopatológicas, basadas en la identificación de las lesiones microscópicas inducidas por la infección en tejidos incluidos en parafina y teñidos mediante la técnica de hematoxilina-eosina, son reconocidas por su buena sensibilidad y especificidad [García Marín et al., 1992c; Barker et al., 1993; Pérez et al., 1996; Withlock, 1999; Gwozdz et al., 2000b; Huda y Jensen, 2003; Kheirandish et al., 2008]. Además, una de sus ventajas es la capacidad de identificar no solo animales con lesiones graves que presenten la enfermedad clínica sino también a animales con lesiones más restringidas asociadas a la enfermedad subclínica [Corpa et al., 2000; González, 2003; González et al., 2005].

Un factor importante a tener en cuenta al llevar a cabo este tipo de estudios es la correcta elección de las muestras a estudiar, ya que siempre deben incluirse aquellas localizaciones que aseguren la presencia de tanto de lesiones iniciales o latentes, como 
graves; en el caso de la tuberculosis incluirían los nódulos linfáticos respiratorios, y en la paratuberculosis la válvula ileocecal, tejido linfoide yeyunal y nódulos linfáticos mesentéricos [García Marín et al., 1992b, 1992c; Condron et al., 1994; Pérez et al., 1996; Garrido et al., 2000; Valheim et al., 2002; González, 2003].

La identificación de lesiones con la identificación de bacilos ácido-alcohol resistentes en los propios tejidos mediante la técnica de Ziehl-Neelsen. Mediante esta técnica no se puede distinguir entre las distintas especies de micobacterias; además presenta una baja sensibilidad puesto que en la mayor parte de las lesiones focales o incluso algunas graves, no presentan bacilos y éstos, para ser teñidos correctamente, necesitan tener la pared celular intacta [Jubb et al., 1985; Barker et al., 1993; Condron et al., 1994; Thorensen et al., 1994; Coetsier et al., 1998; Brees et al., 2000; Prieto et al., 2004; Sevilla, 2007].

\subsubsection{Técnicas inmunohistoquímicas.}

La técnicas histopatológicas pueden complementarse con métodos inmunohistoquímicos, que se desarrollan sobre los mismos tejidos fijados en formol e incluidos en parafina que en los métodos convencionales, y se basan en el empleo de anticuerpos monoclonales o policlonales específicos frente a la micobacteria que permiten poner de manifiesto la presencia de antígenos del microorganismo en dichos tejidos. [Haines et al., 1987; García Marín et al., 1992b; Gutiérrez Cancela y García Marín, 1993].

Esta técnica en comparación con otras, muestra una mayor capacidad para detectar micobacterias [Pérez et al., 1990; Haines y Clark, 1991; Haines y Chelack, 1991; García Marín et al., 1992a; Gutiérrez Cancela y García Marín, 1993; Menchén Ozaita, 1995; Coetsier et al., 1998; Olsen et al., 2002], poniendo en evidencia una menor cantidad de bacilos de forma más específica, sobre todo en lesiones focales y difusas linfocíticas, independientemente de la integridad de su pared, pudiendo marcar microorganismos carentes de la misma o alterados [Pérez et al., 1990; García Marín et al., 1992a; Coetsier et al., 1998; Brees et al., 2000; Balseiro et al., 2003; Delgado et al., 2009]. Se trata de una técnica más específica que la tinción ZN [Brees et al., 2000], sin embargo, el coste económico y el tiempo de realización algunas de sus mayores desventajas.

Uno de los mayores problemas que presenta esta técnica es la heterogeneidad de los anticuerpos primarios empleados, muchos de los cuales no están disponibles comercialmente. Además existe el riego de resultados falsos positivos, ya que se podrían producir reacciones cruzadas con otras micobacterias, por lo que, este método no es considerado completamente especifico [Gutiérrez Cancela y García Marín, 1993; Thoresen et al., 1994; Menchén Ozaita, 1995; Stabel, 1996; Coetsier et al., 1998; Brees et al., 2000]. 


\subsection{Diagnóstico.}

\subsubsection{Aislamiento e identificación en cultivo bacteriológico.}

El cultivo es el método más utilizado para el diagnóstico de las micobacteriosis, principalmente en bovinos y es, considerado como la prueba de referencia ("gold standard") ya que muestra una especificidad de hasta un $100 \%$, y proporciona un diagnóstico definitivo de la enfermedad [Kalis et al., 2001; Huda y Jensen, 2003; Muskens et al., 2003; Collins, 2004; Brown et al., 2007; Pradenas et al., 2008].

Una de las ventajas principales de este método es que puede llevarse a cabo en animales vivos a partir de heces, secreción respiratoria o raspado de la mucosa. También existe la posibilidad de obtener la muestra a partir de una biopsia, aunque esta alternativa únicamente se vería justificada económicamente en animales de especial valor. En el caso del cultivo fecal en paratuberculosis, esta técnica mostraría una sensibilidad del $100 \%$, pero en la fase subclínica esta puede descender hasta un $87,7 \%$, debido principalmente a que los animales en estadios iniciales no eliminan micobacterias en heces o bien estás son muy escasas. Además esta técnica es incapaz de detectar formas de pared defectiva en animales con lesiones focales [Condron et al., 1994; Iob et al., 1996; Zimmer et al., 1999; Garrido et al., 2000; Withlock et al., 2000; Whittington et al., 2000].

Una desventaja muy importante del cultivo de Map es el elevado tiempo de realización, ya que el crecimiento de esta micobacteria es muy lento, requiriendo para ello, de 3 a 6 semanas para la aparición de las típicas colonias pequeñas, blancas y convexas y de 3 a 4 meses para un primer aislamiento [Sweeney et al., 1995; Collins, 1996; Kalis et al., 1999, 2002; Soto et al., 2000]. Además tiene un elevado coste, por ello no siempre permite el uso masivo como herramienta diagnóstica [Collins et al., 1990; Kalis et al., 2002; Wells et al., 2002; Pradenas et al., 2008].

Las micobacterias poseen características biológicas especiales por lo que es necesario utilizar técnicas de laboratorio especiales para su aislamiento. En primer lugar y debido a que las muestras obtenidas de animales infectados, especialmente las heces, son un material altamente contaminado, deben someterse a una descontaminación con el fin de destruir los microorganismos contaminantes o bien, otras bacterias competidoras por los nutrientes [de Lisle et al., 1984; Ridge, 1993; Garrido et al., 2000; Olsen et al., 2002; Reddacliff et al., 2003].

Para ello se emplean diferentes agentes bactericidas como él verde malaquita, el hidróxido de sodio, la neomicina, la anfotericina $\mathrm{B}$ y el ácido oxálico, si bien varios autores consideran que algunos de estos compuestos reducen sensiblemente la viabilidad de las micobacterias. Otros agentes más eficaces son el cloruro de benzalconio y especialmente el 
cloruro de hexadecilpiridinio que ofrecen mejores resultados en cuanto a la viabilidad de las micobacterias y es el más empleado actualmente para el aislamiento de Map [Lagadic et al., 1983; Juste et al., 1991; Sotohy y Awad-Maselmeh, 1999].

Después de la descontaminación, se realiza una concentración de los microorganismos por gravedad o por centrifugación, la cual parece favorecer la velocidad de crecimiento y triplica la sensibilidad del cultivo, aunque hay que tener en cuenta que incrementa el número de contaminaciones [Eamens et al., 2000; Reddacliff et al., 2003].

Para el aislamiento primario de Map es recomendable el uso de medios de cultivo sólido, habitualmente son usados aquellos a base de huevo como el de Herrold, y el de Lowenstein-Jensen (L-J) [Marco y Adúriz, 1990; Corner, 1994; Withlock, 1998; Pávlik et al., 1999; Whittington et al., 2000], a los cuales es necesario añadir micobactina, que es un agente quelante del hierro [Wayne y Kubica, 1986; Adúriz et al., 1995] necesario para el crecimiento de esta micobacteria. Nielsen et al. (2004), consideran que el medio Herrold ofrece un mejor crecimiento y es más rápido que el medio de LJ, mostrando así una mayor eficacia en muestras de ganado bovino, mientras que en pequeños rumiantes sería el LJ el de elección [Juste et al., 1991].

Una alternativa diagnóstica de menor costo para detectar el agente en las heces es el cultivo de una mezcla de deposiciones de varios animales (pool fecal), que ofrece una buena sensibilidad y especificidad [Sweeney et al., 1995; Collins, 1996; Kalis et al., 2000; Whittington et al., 2000; Wells et al., 2002, 2003; Van Schaik et al., 2003].

El cultivo de pool fecales permite examinar un gran número de animales en una explotación a un menor costo, ya que solo los pools positivos necesitan ser re-examinados individualmente para identificar los animales infectados [Pradenas et al., 2008].

Asimismo, la adición de piruvato sódico como estimulante del crecimiento de $M$. bovis fue introducida por Stonebrink. Uno de los medios más utilizados en las últimas décadas ha sido el de Löwestein-Jensen, que resume el medio creado por el primero y la idea del segundo de que el medio tuviese baja proporción de glicerina para que fuese válido para todo tipo de micobacterias [Jensen, 1953], por ello, este medio también se utiliza en el aislamiento de otras bacterias como Map. [Ilukevich Anerik, 1974; Juste et al., 1991].

\subsubsection{Detección del genoma micobacteriano (PCR).}

La genotipificación de aislamientos de las micobacterias ha sido ampliamente utilizada en investigaciones ante brotes epidémicos, como herramienta en estudios de transmisión dinámica y otros aspectos de la epidemiología de la tuberculosis y paratuberculosis. [Cataldi et al., 2002]. El diagnóstico de las enfermedades micobacterianas 
se ha visto favorecido en los últimos años por el desarrollo de técnicas de biología molecular que permiten la detección de las secuencias de inserción específicas para cada micobacteria, que en concreto son: IS6110 específica de M. tuberculosis, IS1081 específica de M. bovis, IS900 específica de Map y IS901 específica de Maa. [Green et al., 1989; Collins et al., 1993a; Morales et al., 2005; Acosta-Salinas et al., 2009; Solmaz et al., 2009].

Entre los principales métodos genéticos utilizados se encuentra la reacción en cadena de la polimerasa o PCR (Polymerase chain reaction) [Bull et al., 2000; Coetsier et al., 2001; Englund, 2003]. Este método permite la identificación del agente etiológico, de una manera rápida y específica, tanto en muestras procedentes de heces [Scott et al., 2007], leche [Buergelt y Williams, 2004; Acosta- Salinas et al., 2009; Kaur et al., 2010], sangre o tejidos [Juste et al., 2005; Singh et al., 2010]. Además, permite amplificar de manera selectiva fragmentos de ADN específicos a partir de cantidades mínimas de ADN diana, incluso en presencia de ADN inespecífico [Hughes et al., 1993; Vaneechoutte et al., 1993; Pérez et al., 1994a; Plante et al., 1996; Garrido et al., 1998; Coetsier et al., 2000].

La reacción PCR es un proceso que consta de tres periodos en los que varía la temperatura. Se inicia con la desnaturalización de la muestra de ADN, que se consigue mediante la elevación de la temperatura a más de $90^{\circ} \mathrm{C}$ durante un minuto, resultando una separación de las hebras de ADN. A continuación, comienza la fase de hibridación, donde los cebadores o iniciadores (oligonucleótidos sintetizados a partir de una secuencia conocida) se unen de una manera específica a su secuencia de ADN complementaria, durante 1 ó 2 minutos a temperatura de $55-65^{\circ} \mathrm{C}$, variando la temperatura final en función del contenido de $\mathrm{G}+\mathrm{C}$ de los cebadores. En la fase de elongación, aumenta la temperatura generalmente a $72^{\circ} \mathrm{C}$ durante 2 ó 3 minutos, favoreciendo que la $\mathrm{ADN}$ polimerasa forme la nueva hebra de ADN a partir de los cebadores. Todo este proceso se repite un número de ciclos de entre 25 y 40, de forma que sea obtenida la cantidad obtenida de ADN sea suficiente para su visualización. Para ello, existen diferentes técnicas, aunque la más común es la que emplea luz ultravioleta tras el corrido electroforético en gel de agarosa teñido con azul de bromofenol [Persing, 1993; Morán et al., 2000].

La principal ventaja de esta técnica es su rapidez (24- 48 horas) en la obtención de resultados [Coetsier et al., 2000; Garrido et al., 2000; Collins et al., 2002; Estrada-Chávez et al., 2004; Retamal y Ábalos, 2004]. Sin embargo, las características de las micobacterias hacen que la extracción de ADN a partir de las muestras analizar sea un factor importante para asegurar la sensibilidad de la técnica, por lo que se han propuesto diferentes métodos de extracción y purificación, como son la centrifugación y el tratamiento con calor [Vary et al., 1990; Ozbek et al., 2003; Garbaccio, 2006; Ramírez et al., 2006], la extracción mediante xilol, el machacado de las muestras con perlas de zirconio [Challans et al., 1994] la utilización de hidróxido de sodio o la separación inmunogenética [Djonne et al., 2003; Khare et al., 2004]. 
En un estudio realizado por Garrido et al. (1998) se compararon diferentes métodos de extracción de Map y su ADN encontrando que compuestos como el SDS y el HPC son más eficaces que el xilol, y que la ruptura de la micobacteria mediante congelación y calor seco alternativamente, y la utilización de Tris-TE tritón X100 consigue un mayor número de resultados positivos.

En el caso de la paratuberculosis, su especificidad y sensibilidad se considera mayor que la del cultivo tanto en animales con lesiones difusas multibacilares y en casos avanzados de la enfermedad [Mason et al., 2001; Estrada-Chávez et al., 2004] como, en animales que eliminan pocas cantidades de micobacterias o que se encuentran en la fase subclínica de la enfermedad [Garrido et al., 2000]. Sin embargo, para otros autores su sensibilidad sería en general inferior a las del cultivo [Pérez et al., 1994a; Withlock, 1999; Mason et al., 2001].

La PCR presenta otra variante de gran valor diagnóstico, que se realiza a partir de muestras de tejido fijadas en formol e incluidas en parafina. Se trata de un método rápido, útil y que presenta una sensibilidad del $71 \%$ en relación al cultivo, del $88 \%$ con la tinción de Ziehl-Neelsen y del 90\% en relación a la inmunohistoquímica [Plante et al., 1996; Miller et al., 1999; Whittington et al., 1999b; Morales et al., 2005], con una especificidad del $100 \%$. Sin embargo, como el formol fragmenta las cadenas de ADN micobacteriano en exposiciones prolongadas (más de una semana), con la consiguiente disminución de la sensibilidad hasta un $70 \%$, precisa una fijación máxima de 24 horas en este tipo de muestras [Miller et al., 1999]. Teniendo en cuenta lo señalado la especificidad de la PCR en muestras incluidas en parafina es extremadamente alta, sin falsos negativos y permite diferenciar entre especies y subespecies de micobacterias [Coetsier et al., 2000; Sanna et al., 2000].

\subsection{Métodos diagnósticos basados en la respuesta inmune del animal.}

Las infecciones por micobacterias inducen una respuesta inmune de tipo adaptativo (celular y humoral) en los animales, que puede detectarse mediante, diferentes técnicas diagnósticas. Además, se ha encontrado una relación entre el tipo de lesión que muestra el animal y la respuesta inmune periférica, de forma que los animales con lesiones iniciales o latentes subclínicas presentan una respuesta inmune de tipo celular elevada, pero al progresar la infección hacia fases más avanzadas y graves, predomina la respuesta de tipo humoral [Gwozdz et al., 2000a; García-Marín et al., 2000; Stabel, 2006].

Por ello, para detectar la cantidad mayor de animales infectados que se encuentran en las distintas fases de la infección, se recomienda emplear simultáneamente distintas técnicas de diagnóstico inmunológico [Pérez et al., 1994b, 1997; Corpa, 1999; García Marín et al., 1999; Stabel y Withlock, 2001; Chávez et al., 2004]. Es importante tener en 
cuenta que en las fases finales de la enfermedad, se pueden observar estados de anergia y estos animales no pueden ser detectados por ninguna prueba inmunológica [Garrido et al., 2000]. Asimismo, la vacunación puede interferir en el diagnóstico mediante este tipo de pruebas [Gwozdz et al., 2000a; Kohler et al., 2001].

\subsubsection{Métodos diagnósticos basados en la respuesta inmune celular.}

Los animales infectados en fases iniciales o con formas latentes de tuberculosis o paratuberculosis, desarrollan una respuesta inmune de tipo celular que, es detectable mediantes diferentes pruebas diagnósticas que se dividen en dos grandes grupos: las pruebas "in vivo" como la intradermorreacción o la prueba de la tuberculina [Monaghan et al., 1994; García Marín et al., 1999; Pérez et al., 1999; Kalis et al., 2003] y las pruebas “in vitro" o laboratoriales, donde destaca la más empleada, la prueba de liberación del Interferón-gamma (IFN- $\gamma$ ), aunque existen otras como la detección del receptor de interleuquina 2 (IL-2R), la inhibición de la migración linfocitaria y la transformación linfocitaria [Outteridge y Lepper, 1973; Wood et al., 1990; García Marín et al., 1999; Whist et al., 2000; Kalis et al., 2003].

\subsubsection{Prueba de la tuberculina.}

El término tuberculina se aplica a un extracto obtenido de filtrados de cultivos micobacterianos, previamente esterilizados. Las micobacterias son cultivadas en medio líquido, muertas por calor y separadas por filtración. El líquido filtrado se concentra por calor hasta un décimo de su volumen original. En los primeros tiempos se empleaba como medio de cultivo el caldo de carne glicerinado, que posteriormente fue reemplazado por medio sintético (HCSM). Con ello se evitaba agregar al producto final proteínas heterólogas provenientes del medio de cultivo [Mederos et al., 1997]. La preparación de derivados proteicos purificados (PPD) es similar a la de la tuberculina, si bien en vez de concentrar las proteínas por acción del calor, se les separa por precipitación con agentes químicos, tales como: el sulfato de amonio o el ácido tricloroacético [Mederos et al., 1997]. De esta manera, se logra elaborar un producto estandarizado y conservar mejor la estructura proteica original [Burrells et al., 1995; Shirakawa et al., 1997].

En el diagnóstico de la paratuberculosis, los antígenos más utilizados son los derivados proteicos purificados, obtenidos a partir de Map, denominados PPD johnina o paratuberculina, o bien a partir de Maa (PPD aviar). Esta última, disponible comercialmente, es la más utilizada ya que posee una elevada similitud antigénica con la PPD johnina, con sensibilidades y especificidades muy parecidas [Pávlik et al., 1999; Garrido et al., 2000; Stabel y Withlock, 2001]. 
La prueba de la tuberculina, descubierta en 1890 por Robert Koch, se utiliza en el diagnóstico de la tuberculosis en el ganado bovino [Buddle et al., 1995; Rivera et al., 2009]. Se basa en la inoculación de las proteínas de origen bacilar en el animal y en la posterior detección de la hipersensibilidad de tipo retardado que ha causado la infección micobacteriana. [Feldman y Fitch, 1936]. En un principio se aplicó de forma subcutánea, pero era costosa en tiempo y esfuerzo, ya que requería tomar al menos 5 veces la temperatura, por lo que fue sustituida por la vía intradérmica de tuberculinización descrita por Moussu y Mantoux en 1908 en la especie humana [Monaghan et al., 1994]. ). En España y en la mayoría de los países esta prueba se lleva a cabo en la piel de la espalda del animal [Cuezva Samaniego, 1966; O’Reilly, 1993b] aunque en EEUU, Australia y Nueva Zelanda se tuberculiniza en el pliegue de la cola, si bien se ha encontrado que la aplicación de la tuberculina en las tablas del cuello ofrece mayor sensibilidad, mientras que en el pliegue caudal se obtiene una mayor especificidad [Larsen et al., 1957; Kantor et al., 1984; Guanziroli et al., 2005].

La prueba de la tuberculina se ha utilizado desde hace más de 100 años como método de diagnóstico en las campañas de control y erradicación de la tuberculosis, siendo estandarizada por la OMS en 1951. Esta técnica, de bajo coste, constituye una herramienta básica para detectar la presencia de la infección tuberculosa ya que ha permitido reducir marcadamente su prevalencia en los países donde se ha aplicado [O’Reilly, 1969; 1993b; Kantor, 1984; Arcelles et al., 2005; Underwood y Carfagnini, 2005; Marco et al., 2011]. El test intradérmico simple cervical en bovinos se declaró oficial en Finlandia en 1910, extendiéndose en otros países.

El procedimiento de realización de la intradermorreacción o prueba de la tuberculina consiste en la inyección intradérmica en la piel del cuello de $0,1 \mathrm{ml}$ a una dosis igual o superior de 2.000 UI de tuberculina bovina o PPD (obtenida a partir de M. bovis) para el diagnóstico de los animales sensibilizados frente a tuberculosis [Feldman y Fitch, 1936; Cuezva Samaniego, 1966] y 0,1 a 0,2 ml de johnina (a partir de Map) o PPD aviar (a partir de Maa) frente a paratuberculosis [Gilmour y Brotherson, 1966; Chiodinni et al., 1984]. La hipersensibilidad se manifiesta por una inflamación en el sitio de la inyección, que se traduce en un endurecimiento al tacto de volumen de la piel. Esta reacción se valora midiendo el pliegue dérmico en el momento de la inoculación y a las 72 horas de haber efectuado la misma [Huchzermeyer et al., 1994; Whipple et al., 1995; García Marín, 1996; Withlock et al., 1999; Contreras, 2000].

A las 72 horas de la tuberculinización, los individuos sensibilizados a tuberculosis o paratuberculosis, muestran un engrosamiento de la piel, debido al reconocimiento local por parte de los linfocitos $\mathrm{T}$ de proteínas del bacilo tuberculoso por un mecanismo de hipersensibilidad celular de tipo retardado [Feldman y Fitch, 1936; Kubabara, 1975 a; b]. 
La interpretación de la prueba se realiza de acuerdo a lo establecido por la Organización Mundial de la Salud. En el test simple (diagnóstico de tuberculosis bovina) se considera no reaccionante, aquel bovino con engrosamiento del pliegue de piel inferior a 2 mm y sin ningún tipo de signo clínico; dudoso, con un engrosamiento entre 2 y $4 \mathrm{~mm}$ sin presentar signos clínicos; positivo, con un engrosamiento superior a $4 \mathrm{~mm}$ con o sin signos clínicos o superior a $2 \mathrm{~mm}$ y con signos clínicos [NOM-031-ZOO, 1995; Morales et al., 2008].

En el test comparado (diagnóstico de tuberculosis y paratuberculosis) se considera positivo, aquel bovino que presenta un incremento del grosor de la piel superior a $4 \mathrm{~mm}$ a la reacción de la tuberculina bovina en comparación a la reacción de la tuberculina aviar, o bien, que presente signos clínicos asociados al lugar de inoculación de la tuberculina bovina; dudoso, cuando el grosor de la piel en el lugar de tuberculina bovina es entre 1 y 4 mm superior al del lugar de la tuberculina aviar y no presenta signos asociados, y negativo; cuando la reacción a la tuberculina bovina es menor o igual grosor que la reacción aviar y sin signos clínicos [Monaghan et al., 1994].

El principal inconveniente para la estimación de la sensibilidad y de la especificidad de esta prueba, es la dificultad de la lectura del test por parte del técnico, ya que la asignación de positividad o negatividad en un animal puede haber sido no realizada de la manera adecuada. A esto se suma el no sacrificio de los animales negativos a la prueba para determinar su verdadero estado de infección, siendo imposible calcular los "falsos negativos". Los valores de sensibilidad en el diagnóstico de tuberculosis bovina se han estimado entre un 77 y 95\% [Monaghan et al., 1994] y entre un 90 y 95\% [Morrison et al., 2000; Escobar et al., 2004]. Para la prueba simple caudal con PPD bovina, se ha observado una sensibilidad del $81,9 \%$ y una especificidad del 96,3\% [Rivera et al., 2009] y para la prueba comparada con PPD-bovino y aviar la sensibilidad varía del 72 al $78 \%$ y la especificidad del 92 al 99\% [Cicuta et al., 2003].

\subsubsection{Métodos diagnósticos basados en la respuesta inmune humoral.}

Estas pruebas se basan principalmente en la detección de anticuerpos específicos frente a diferentes tipos de micobacterias. Se trata de técnicas rápidas, que permiten analizar un elevado número de muestras simultáneamente. Una vez que se dispone de los antígenos adecuados, la obtención de las muestras es sencilla y su procesado barato, pues no requiere equipos complejos de laboratorio [Ridge et al., 1991; Kalis et al., 2002]. En la paratuberculosis, estas pruebas presentan una sensibilidad baja ya que sólo detectan animales infectados en los que la respuesta humoral se hace evidente [Juste y Adúriz, 1990a; Pérez et al., 1997; Kalis et al., 2002], por lo que serían útiles para confirmar el diagnóstico clínico de la enfermedad o identificar animales excretores de gran cantidad de micobacterias. Sin embargo, presentan una gran desventaja, ya que no son capaces de 
identificar animales en fases subclínicas [López et al., 1997]. Por ello, si se pretende detectar un mayor número de animales infectados en una explotación, estas pruebas deberían complementarse con las que valoran la respuesta inmune celular [Pérez et al., 1994b, 1997, 1999; García Marín et al., 1999; Stabel y Whitlock, 2001].

Actualmente, la prueba de inmunidad humoral más empleada es el ensayo por inmunoabsorción ligado a enzimas (ELISA), si bien también se utilizaron el y el test de fijación del complemento (FC), la prueba de inmunodifusión en gel de Agar (IDGA) y la prueba del gamma interferón ( $\gamma$ IFN).

\subsubsection{Prueba de inmunodifusión en gel de agar (IDGA).}

Esta prueba consiste en la apreciación a simple vista de la precipitación del complejo antígeno-anticuerpo cuando existen anticuerpos suficientes a través de una placa de gel de agar, enfrentando un antígeno específico con un suero problema, ambos situados en pocillos contiguos [Juste y Adúriz, 1990b; Pérez et al,, 1997; Sevilla, 2007]. Se ha empleado en el diagnóstico de la paratuberculosis, demostrando ser un método diagnóstico barato, rápido y fácil de realizar aunque de baja sensibilidad, que varían del 18,9 al 57\% en el ganado bovino [Sherman et al., 1984; Ferreira et al., 2002]. Su eficacia depende de la fase de infección en la que se encuentre el animal [Pérez et al., 1997; Sergeant et al., 2003]. En bovinos con síntomas clínicos, confirmados mediante el estudio anatomopatológico y bacteriológico se han comunicado sensibilidades del 96,9\% [Sherman et al., 1984] y del 54,5\% [Colgrove et al., 1989]. Sockett et al. (1992) detectaron un 40,5\% de animales excretores, tanto en la fase clínica como subclínica. En animales con infección subclínica los valores de sensibilidad apenas alcanzaron el 18,9\% [Sherman et al., 1990].

En cuanto a la relación entre las lesiones y los resultados a esta prueba diagnóstica, la positividad se encuentra estrechamente relacionada a los últimos estadios de la infección $\mathrm{y}$, a la presencia de lesiones severas difusas multibacilares, pudiendo alcanzar una sensibilidad de entre el 94 y $100 \%$ en animales con lesiones de ese tipo en casos naturales de la enfermedad [Clarke et al., 1996; Pérez et al., 1997; García Marín et al., 1992c, 1994, 1999]. Sin embargo, en animales con lesiones difusas paucibacilares sólo detecta entre el 20 y 30\% [Clarke et al., 1996; Pérez et al., 1997] y el 5,5\% de animales con lesiones leves o focales [García Marín et al., 1992c; Pérez et al., 1997; González, 2003].

La especificidad de esta técnica puede considerarse como elevada, con resultados de hasta el $100 \%$ en casos naturales de la infección por paratuberculosis [García Marín et al., 1992c; Pérez et al., 1997; Ferreira et al., 2002; González, 2003; Sergeant et al., 2003]. 


\subsubsection{Ensayo inmunoenzimático (ELISA).}

El ensayo inmunoenzimático (ELISA) es una técnica ampliamente utilizada en el diagnóstico de paratuberculosis desde su empleo por primera vez por Jorgensen y Jensen en 1978 en la especie bovina. Igualmente, y Thoen et al. (1983) describen un procedimiento para el diagnóstico de la tuberculosis bovina. Su éxito se debe a que es una técnica económica, rápida y fácil de realizar. Además permite procesar una gran cantidad de muestras. El test ELISA consiste en hacer reaccionar los anticuerpos presentes en el suero de los animales infectados con un antígeno fijado a las paredes de un pocillo de plástico. Después del lavado de todos los anticuerpos que no se fijaron al antígeno, se revela la presencia de los complejos específicos mediante un reactivo (anticuerpo con afinidad específica por las inmunoglobulinas) que lleva incorporada una enzima (conjugado). Tras lavados para eliminar el exceso de conjugado, se añade el sustrato de enzima. Si la reacción es positiva se podrá detectar una reacción colorimétrica que será proporcional a la cantidad de anticuerpos específicos presentes en la muestra [Collins et al., 1993a; Díaz et al., 1999; Garrido et al., 2000].

Son muchos los antígenos que se emplean por los diferentes laboratorios para la realización de la técnica, aunque los más utilizados en paratuberculosis son el antígeno protoplasmático purificado crudo o PPA-3 [Lyle y Merkal, 1983; Yokomiso et al., 1983; Richards, 1990; Hardin y Thorne, 1996; Pérez et al., 1997; Garrido, 2001; González, 2003; Balseiro, 2004]. También se emplean otros como el LAM [Sugden et al., 1989; Dolz et al., 1999; Reichel et al., 1999], los antígenos A y D [Sugden et al., 1989], el polipéptido recombinante a362 [Vannuffel et al., 1994], entre otros. En el caso de la tuberculosis, los antígenos más ampliamente utilizados han sido el PPD bovina [Thoen et al., 1983; Hanna et al., 1989], la proteína de secreción MPB70, la cual se ha mostrado como altamente específica [Fifis et al., 1992; Acosta et al., 2000]. Últimamente, se emplean antígenos recombinantes, que están siendo más específicos que los tradicionales [Lyashchenko et al., 1998; Amadori et al., 2002].

En el caso de la paratuberculosis, esta prueba diagnóstica puede dar como resultado falsos positivos, ya que las enfermedades por micobacterias presentan numerosas similitudes antigénicas con otras micobacterias ambientales. Una alternativa para reducir este riesgo consistió en la introducción de una fase previa de preabsorción del suero problema con Mycobacterium phlei, lo que permite la eliminación de gran parte de las reacciones cruzadas con otras micobacterias o microorganismos, incrementando la especificidad del ELISA [Yokomiso et al., 1983, 1991; Bech-Nielsen et al., 1992, 1993].

El diagnóstico positivo mediante ELISA indirecto de las infecciones producidas por micobacterias, está estrechamente vinculado a la fase en la que se encuentra el animal. En el caso de la paratuberculosis, presenta una baja sensibilidad en la detección de los 
animales en la etapa inicial de la infección que eliminan pequeñas cantidades de micobacterias ya que carecen de anticuerpos o bien estos se encuentran en una cantidad muy baja, insuficiente para desencadenar una reacción positiva a la prueba de ELISA [Garrido, 2001; Soto et al., 2002; Pak et al., 2003].

En este sentido, Sweeney et al. (1995) y Withlock et al. (2000) coinciden en afirmar, que los animales en etapas iniciales de la enfermedad, aun excretando bacterias en heces, no pueden ser detectados por el test ELISA. En estos casos deberían de transcurrir, varios meses o años para que los niveles de anticuerpos circulantes fueran suficientes para desencadenar una reacción positiva.

La sensibilidad de la prueba de ELISA se ha cifrado en un $45 \%$ de promedio, con valores extremos de un $15 \%$ y $87 \%$ en animales en fase subclínica y clínica respectivamente, con una especificidad entre el 84,7\% y 100\% [Sweeney et al., 1995; Pérez et al., 1997; Stabel, 1998; Gasteiner et al., 2000; Garrido, 2001; Olsen et al., 2001; Soto et al., 2002].

Los valores de sensibilidad y especificidad de esta prueba se encuentran estrechamente relacionados con los diferentes tipos lesionales, siendo detectados entre un $86,4 \%$ y el $100 \%$ de con lesiones de tipo difuso multibacilar o de un $10-50 \%$ en aquellos con formas difusas de tipo paubacilar. Como se ha señalado, esta técnica es limitado para la detección de animales en la fase subclínica, alcanzando una sensibilidad del 15,8\% en el caso de lesiones focales y del $14,3 \%$ en lesiones multifocales, en el ganado bovino [González, 2003].

\subsubsection{La prueba de gamma interferón.}

Esta técnica de diagnóstico laboratorial está basada en la liberación de la citoquina gamma-interferón por parte de los linfocitos $\mathrm{T}$ sensibilizados estimulados por antígenos micobacterianos y su cuantificación utilizando un anticuerpo monoclonal frente la misma [Wood et al., 1989; Wood et al., 1991; Billman-Jacobe et al., 1992; Pérez et al., 1994b; Burrells et al., 1998]. Aunque en un principio fue desarrollada para el diagnóstico de la tuberculosis bovina, empleando antígenos procedentes de $M$. avium como la PPD aviar o la Johnina, se demostró su utilidad para la detección de la infección paratuberculosa [Wood et al., 1989; Wood et al., 1991; Burrells et al., 1995; McDonalds et al., 1999], no solo en esta especie, sino también en oveja, cabra y búfalo [Rothel et al., 1990; Pérez et al., 1994b; Corpa, 1999].

Se basa en el cultivo de sangre heparinizada con antígeno de $M$. bovis durante 16-24 horas con la medida de producción de una linfoquina, el gamma interferón, por parte de los linfocitos T CD4+ tipo 1 [Wood et al., 1991]. La cuantificación del gamma interferón se 
realiza mediante un ELISA de captura en el que las placas llevan fijado un anticuerpo monoclonal antigamma interferón bovino. Como la prueba utiliza el mismo antígeno que el empleado en la prueba de la tuberculina (PPD) aviar para distinguir las reacciones no específicas de las específicas. Esta prueba fue desarrollada como alternativa al test de transformación linfocitaria que cuantifica la proliferación de linfocitos $\mathrm{T}$ y, que para el diagnóstico rutinario presenta los inconvenientes de ser un proceso largo, complejo y que precisa instalaciones adecuadas para el manejo de isótopos radioactivos [Wood et al., 1991]. 


\section{MATERIALES Y MÉTODOS}

"No estudio por saber más, sino por ignorar menos"

Sor Juana Inés de la Cruz (1651-1695) 


\section{III.1. LUGAR DE ESTUDIO.}

Nayarit es uno de los 31 estados que junto al Distrito Federal conforman las 32 entidades federativas de México. Se encuentra situado al noroeste, limita al norte con Sinaloa, Durango y Zacatecas, al sur con Jalisco y al oeste con el Océano Pacífico (Fig. III.1.).

El estado se divide en 20 municipios: Acaponeta, Ahuacatlán, Amatlán de Cañas, Bahía de Banderas, Compostela, El Nayar, Huajicori, Ixtlán del Río, Jala, La Yesca, Rosamorada, Ruiz, San Blas, San Pedro Lagunillas, Santa María del Oro, Santiago Ixcuintla, Tecuala, Tepic (capital de Nayarit), Tuxpan y Xalisco (Fig. III.2.).

Según los datos del censo de población y vivienda realizado por el Instituto Nacional de Estadística y Geografía (INEGI) hasta el año 2010, el estado de Nayarit contaba con una población de 1,084.979 habitantes, de los cuales 541,007 eran hombres y 543,972 mujeres.

$\mathrm{Su}$ altitud sobre el nivel del mar es de 2.760 m., con un clima predominante semicálido. La temperatura media anual del estado es de $25^{\circ} \mathrm{C}$, con temperaturas mínimas en el mes de enero de $10^{\circ} \mathrm{C}$ de media y temperaturas máximas ligeramente superiores a los $35^{\circ} \mathrm{C}$ en los meses de mayo y junio. La precipitación media anual es de $1100 \mathrm{~mm}$.

Las principales actividades son: ganadería (bovino, ovino, caprino, porcino y aves de corral), pesca (robalo, huachinango, salmón y lisa, además de ser el número uno en la producción de gambas), industrias (azucarera y tabacalera), comercio y turismo. La Secretaría de agricultura, ganadería, desarrollo rural, pesca y alimentación (SAGARPA) informó que en 2013 Nayarit contaba con 679.561 cabezas de ganado bovino (662.651 de carne y 16.910 de leche). 


\section{MÉXICO}

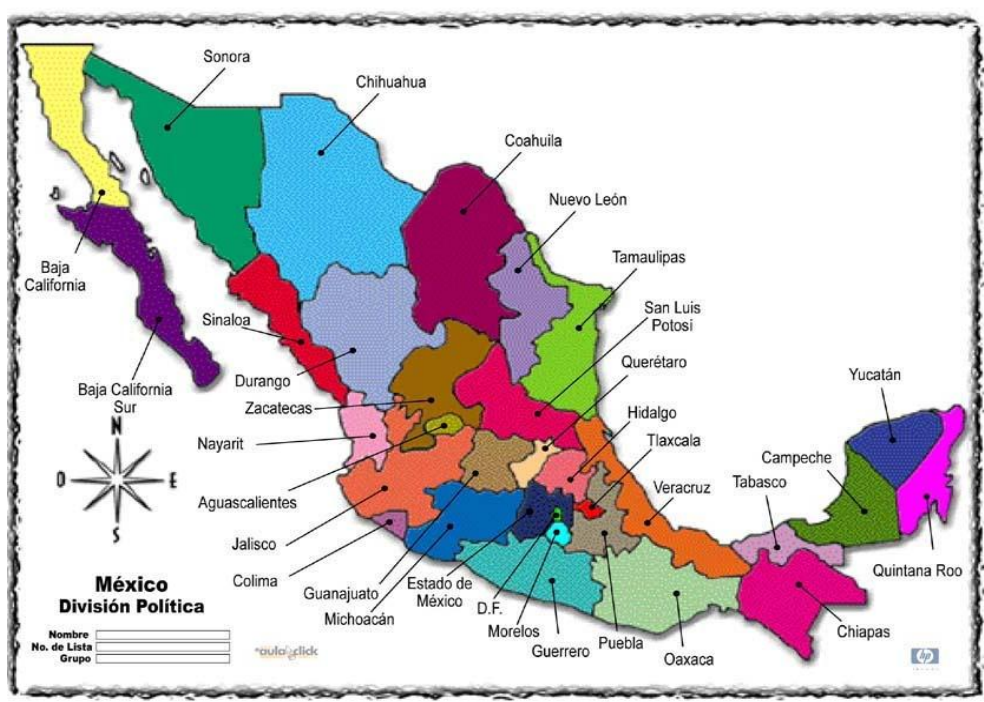

Figura III.1. Distribución geográfica de México.

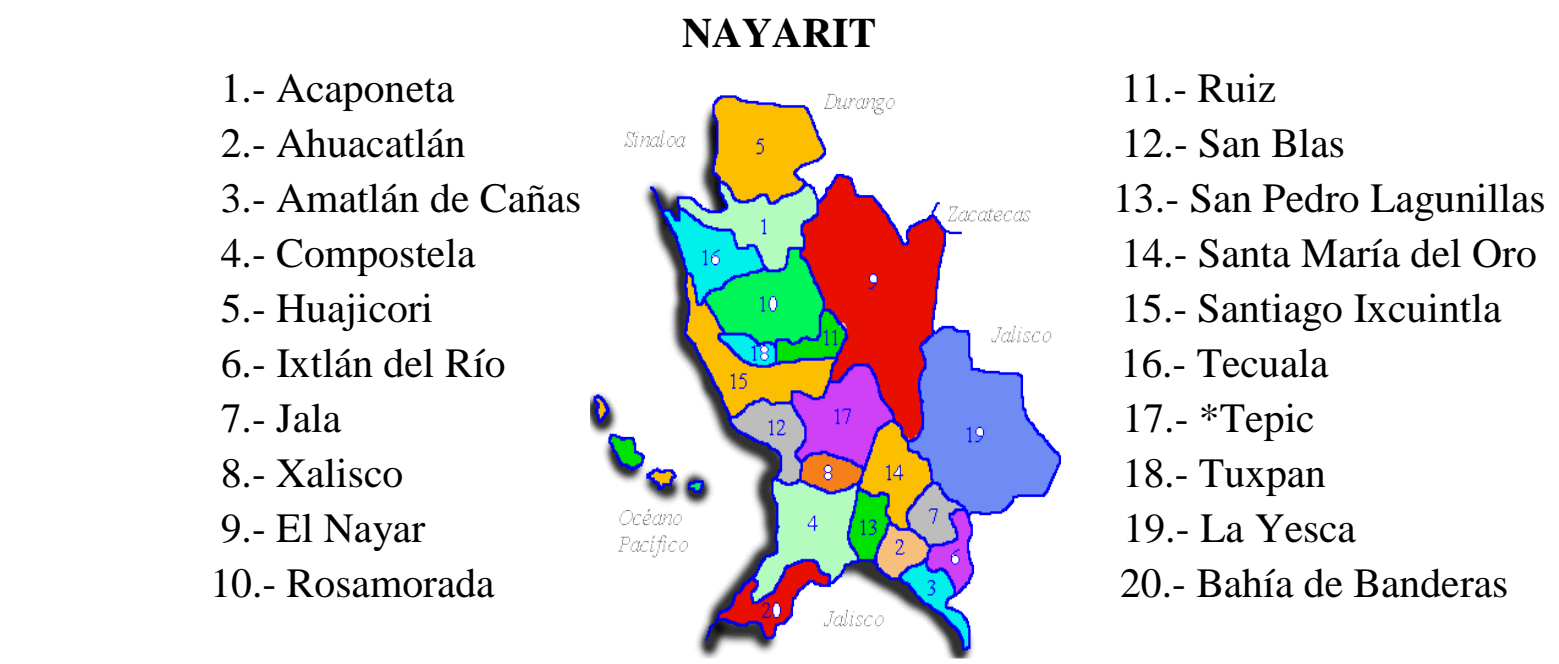

*Lugar donde fueron tomadas todas las muestras, objeto de estudio.

Figura III.2. Distribución geográfica de Nayarit. 


\section{III.2. SELECCIÓN DE ANIMALES.}

Para la realización de esta tesis se han empleado animales de la especie bovina que provenían de las campañas de erradicación de la tuberculosis, sacrificados en el matadero de la Ciudad de Tepic (México) en el período de febrero, marzo y abril del 2011 y en el periodo de febrero, marzo y abril del 2012. Se estudiaron 343 bovinos, 289 mayores de dos años y los 54 restantes menores de 2 años de edad, procedentes de los 20 municipios mencionados anteriormente. Se clasificaron en grupos de la A a la T. Del total de animales 62 eran machos y 281 hembras. Los bovinos fueron clasificados por su edad: menores de 2 años [vaquillas $(n=21)$ y toretes $(n=33)$ ] y mayores de 2 años [vacas $(n=260)$ y toros $(\mathrm{n}=29)]$ y lugar de procedencia. (Tabla III.1).

\begin{tabular}{|ccccc}
\hline Procedencia & $\mathbf{2}$ años & $\mathbf{2}$ 2 años & Identif. & Grupo \\
\hline Acaponeta & 2 & 11 & A1 a A13 & A \\
\hline Ahuacatlán & 2 & 11 & B1 a B13 & B \\
\hline Amatlán de Cañas & 2 & 6 & C1 a C8 & C \\
\hline Compostela & 7 & 24 & D1 a D31 & D \\
\hline Huajicori & 0 & 12 & E1 a E12 & E \\
\hline Ixtlán del Río & 1 & 10 & F1 a F11 & F \\
\hline Jala & 6 & 8 & G1 a G14 & G \\
\hline Xalisco & 1 & 11 & H1 a H12 & H \\
\hline El Nayar & 2 & 19 & I1 a I21 & I \\
\hline Rosamorada & 4 & 14 & J1 a J18 & J \\
\hline Ruiz & 4 & 7 & K1 a K11 & K \\
\hline San Blas & 2 & 6 & L1 a L8 & L \\
\hline San Pedro Lagunillas & 2 & 15 & M1 a M17 & M \\
\hline Santa María del Oro & 4 & 21 & N1 a N25 & N \\
\hline Santiago Ixcuintla & 3 & 6 & O1 a O9 & O \\
\hline Tecuala & 1 & 19 & P1 a P20 & P \\
Tepic & 2 & 31 & Q1 a Q33 & Q \\
\hline Tuxpan & 5 & 8 & R1 a R13 & R \\
\hline La Yesca & 4 & 43 & S1 a S47 & S \\
\hline Bahía de Banderas & 0 & 7 & T1 a T7 & T \\
\hline Total & 54 & 289 & 343 & \\
\hline
\end{tabular}

Tabla III.1. Distribución de los 343 bovinos en los 20 municipios (grupos A - T).

Las muestras se obtuvieron tras el sacrificio de los bovinos mediante aturdimiento con pistola de "bala cautiva" y desangrado y faenado habitual en matadero. 


\section{III.3. ESTUDIOS REALIZADOS.} continuación:

Se llevaron a cabo las siguientes pruebas diagnósticas que se explican a

1) La prueba de Intradermorreacción (IDR) solo en animales mayores de 2 años: n=289.

2) Test ELISA-tb (frente al complejo M. tuberculosis) y ELISA-ptb (frente a M. avium subsp. paratuberculosis): $\mathrm{n}=320$.

3) PCR en muestras de tejido (para la identificación de M. bovis, Map y Maa): n=275 y PCR para la identificación de $M$. avium subsp. avium (Maa): n=14.

4) Valoración de lesiones mediante estudios histológicos (Histología): n=62.

En un total de 35 animales se pudieron realizar las cuatro pruebas diagnósticas (IDR, ELISA-tb, ELISA-ptb, PCR-tb, PCR-ptb e histología).

-En 23 bovinos: Histología + ELISA tb y ptb + IDR.

-ELISA tb y ptb + IDR + PCR: 177 animales.

-En 4 animales: ELISA t y ptb + PCR + Histología.

-ELISA tb y ptb + IDR en 38 animales.

-ELISA tb y ptb + PCR en 36 animales.

-En 16 animales, IDR + PCR.

-En un total de 14 animales sólo se efectuó una prueba: en 7 la PCR y en otros 7 el ELISA tb y ptb.

\subsection{Intradermorreacción (IDR) simple.}

Todos los animales mayores de 2 años $(n=289)$ fueron sometidos a la prueba de intradermorreacción simple en el curso del programa oficial de erradicación de la tuberculosis bovina, aplicada por personal capacitado por el Comité Estatal para el Fomento y Protección Pecuaria de Nayarit, S.C. en cada municipio del cual procedían dichos bovinos.

Dicha prueba se aplicó en el pliegue ano-caudal. Primeramente, se midió el grosor de la piel con un calibre en los puntos en que se iba a proceder a inyectar la tuberculina. A continuación, se inyectó intradérmicamente $0,1 \mathrm{ml}$ de PPD bovina a una concentración de $1 \mathrm{mg} / \mathrm{ml}$. La lectura se realizó a las 72 horas midiendo nuevamente el grosor de la piel. Para la interpretación de los resultados se consideraron tres categorías reaccionantes, según la intensidad de la reacción: 
(i) Positivo: $5 \mathrm{~mm}$ o mayor.

(ii) Sospechoso: entre $3 \mathrm{~mm}$ y $5 \mathrm{~mm}$.

(iii) Negativo: menos de $3 \mathrm{~mm}$.

\subsection{Prueba del test ELISA indirecto frente a tuberculosis y paratuberculosis.}

\subsubsection{Toma y procesamiento de muestras.}

La valoración de la respuesta inmune humoral periférica frente a la tuberculosis y paratuberculosis, se llevó a cabo en 320 animales. Las muestras de sangre fueron tomadas en tubos de extracción sin aditivos de $5 \mathrm{ml}$ (Vacutainer ${ }^{\circledR}$, Reino Unido), una vez sacrificados los animales, directamente del fluido sanguíneo ocasionado por el degüello. Posteriormente, los tubos se mantuvieron a temperatura ambiente durante 24 horas para permitir una correcta coagulación de la sangre y extraer el suero, que se almacenó congelado a $-20^{\circ} \mathrm{C}$ en tubos viales tipo Eppendorf hasta su procesado.

El procesado de las muestras se realizó mediante el test ELISA (Enzime Linked Immunoabsorbent Assay) siguiendo el protocolo descrito por Pérez et al. (1997) con algunas modificaciones, utilizado normalmente por nuestro grupo de investigación.

\subsubsection{Desarrollo de la prueba ELISA.}

En la tabla III.2 se indican todos los reactivos utilizados en la ejecución de esta técnica.

\section{Tuberculosis.}

La adsorción del antígeno al pocillo se realizó mediante incubación de 200 $\mu 1 /$ pocillo de una solución de PPD bovina [100 $\mu 1$ de PPD bovina comercial (CZ Veterinaria, Porriño, España) en $20 \mathrm{ml}$. de tampón carbonato] durante 14 a 16 horas aproximadamente a $4^{\circ} \mathrm{C}$. Posteriormente se realizaron lavados con una solución salina. Las placas adsorbidas se lavaban 5 veces para utilizarse el mismo día y 3 veces para congelarse a $-20^{\circ} \mathrm{C}$ hasta su utilización.

Para la realización de la técnica, se emplearon $200 \mu \mathrm{l}$ de suero problema a una dilución 1:100 en PBS-TG que fueron añadidos en cada pocillo. Las placas se incubaron durante 60 minutos a temperatura ambiente en cámara húmeda Transcurrido ese tiempo se lavaron 6 veces con PBS-TG. Se utilizó como conjugado proteína G marcada con peroxidasa a una dilución de 1:1.000. Las placas se incubaron de nuevo a temperatura ambiente en cámara húmeda durante 60 minutos y después se lavaron 5 veces con PBS-TG. En este momento se añadían $160 \mu \mathrm{l}$ de la solución de sustrato y se incubaban durante 25 
minutos en oscuridad y a temperatura ambiente en cámara húmeda, frenándose posteriormente con la adición de $40 \mu \mathrm{l}$ por pocillo de la solución de frenado.

\section{Paratuberculosis.}

El primer paso de la técnica, consistió en adsorber el antígeno protoplasmático de Map PPA3 (Allied Monitor Lab. Inc., Fayette, Missouri, EEUU) en microplacas de polietileno de fondo plano. Se dispensaron $100 \mu 1 /$ pocillo del antígeno PPA3 a una concentración de $0,04 \mathrm{mg} / \mathrm{ml}$ en tampón carbonato y, posteriormente se incubó entre 14-16 horas. Las placas adsorbidas se lavaron 4 veces para ser usadas en el momento o 3 veces para congelarse a $-20^{\circ} \mathrm{C}$ hasta su utilización.

Por otro lado, se diluían $50 \mu \mathrm{l}$ de cada suero problema en $50 \mu \mathrm{l}$ de una suspensión de Mycobacterium phlei (Allied Monitor Lab. Inc., Fayette, Missouri, EEUU), a una relación 1:1, en una placa no adsorbida, dejándola 2 horas en agitación a temperatura ambiente en cámara húmeda, con el fin de evitar reacciones inespecíficas. A continuación, se extraían $20 \mu 1$ de la placa inicial, con ayuda de una pipeta multicanal, mezclándolos con $180 \mu \mathrm{l}$ de PBS-TG en una placa intermedia no adsorbida, de la que finalmente se volvían a tomar $20 \mu \mathrm{l}$ que se mezclaban con $80 \mu \mathrm{l}$ de PBS-TG en la placa final adsorbida con PPA-3 consiguiéndose una dilución final para cada suero de 1/100. Se sometía a incubación otras 2 horas a temperatura ambiente en cámara húmeda $\mathrm{y}$, trascurrido ese tiempo, la placa se lavaba 5 veces con PBS-TG. A continuación se añadían a cada pocillo $100 \mu$ de conjugado (proteína G) con PBS-T a una dilución de 1/1500. La incubación se repitió en las mismas condiciones que en el paso anterior y, tras realizar 4 nuevos lavados con PBS-TG, se dispensaron $100 \mu \mathrm{l}$ del sustrato ABTS en cada pocillo. La placa se incubaba de 20 a 25 minutos en oscuridad y agitación. Pasado este tiempo, se detenía la reacción, añadiendo 100 $\mu \mathrm{l}$ de solución de frenado a cada pocillo

Todas las muestras, tanto para tuberculosis como paratuberculosis se procesaron por duplicado en pocillos contiguos. En cada placa se reservaban 12 pocillos para los controles positivos y negativos que se procesaban por duplicado en tres puntos diferentes de la placa, normalmente dos esquinas en diagonal y en el centro como se muestra en la Figura III.3. El control positivo consistía en el suero de un mismo animal infectado, positivo a la prueba ELISA y de valor conocido previamente. Para el control negativo se utilizó tampón PBSTG. 


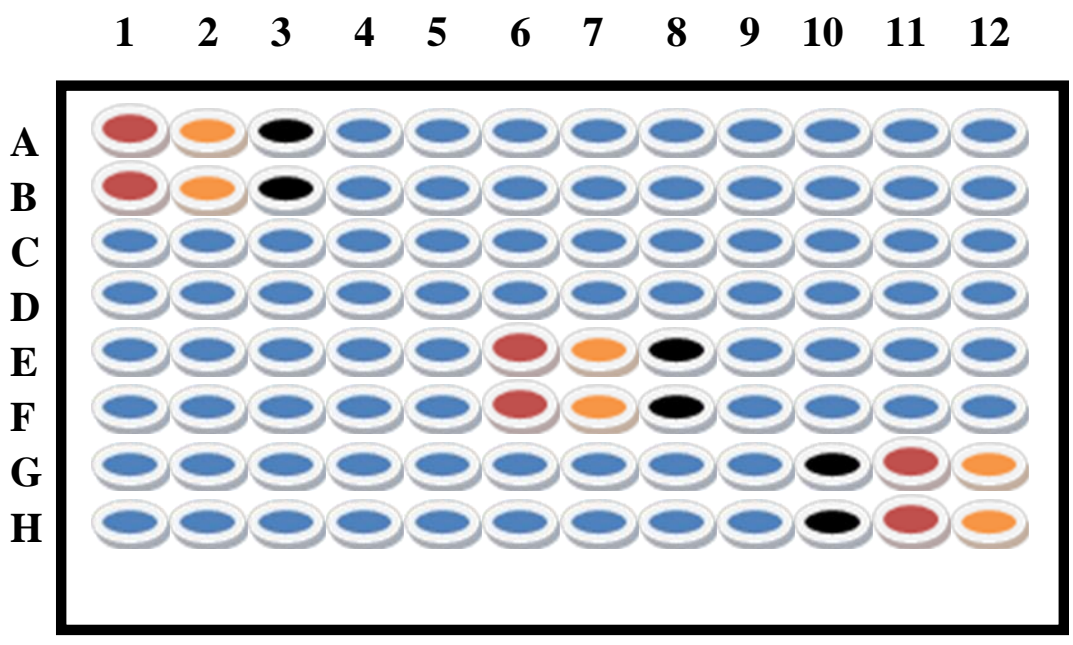

Figura III.3. Distribución de los sueros en la placa del test ELISA PPA-3 y de tuberculosis. Control Positivo Control Negativo: 1 . Muestra por duplicado:

\section{Composición de los reactivos utilizados en la técnica ELISA}

\section{Solución salina de lavado:}

* Cloruro sódico: 8,5 gr.

* Tween 80: 0,5 ml.

* Agua destilada: $1000 \mathrm{ml}$.

2. PBS-TG (solución para lavar las placas incubadas):

* Fosfato monosódico monohidratado: 1,8 gr.

* Fosfato disódico anhidro: 12,36 gr.

* Cloruro sódico: 8,5 gr.

* Agua destilada: $993 \mathrm{ml}$.

* pH 7.6 ajustado con $\mathrm{NaOH}$.

* Tween 80: 0,5 ml.

3. Tampón citrato $0,05 \mathrm{M}$ :

* Ácido cítrico monohidrato: 3,8 gr.

* Citrato sódico tribásico: 3, 52 gr.

* Añadir agua destilada hasta $500 \mathrm{ml}$.

* Ajustar el pH a 4.

4. Tampón carbonato:

* Carbonato sódico $\left(\mathrm{Na}_{2} \mathrm{CO}_{3}\right)$ : 5,3 gr.

* Agua destilada: $1000 \mathrm{ml}$.

* pH 9.6 ajustado con HCL.

5. Sustrato ABTS: 2,2'-azino-di-(ethyl-benzyl-thiazoline sulfonate):

* ABTS: 5,48 gr.

* Tampón citrato: $50 \mathrm{ml}$.

* Añadir $19 \mu \mathrm{l}$ de solución madre 1/25 de agua oxigenada (5 $\mu 1$ de agua oxigenada comercial de 30 volúmenes en $120 \mu$ l de agua destilada).

\section{Solución de frenado:}

* Ácido fluorhídrico (45\%) 0,1 M: 889,33 $\mu 1$.

* Agua destilada: $20 \mathrm{ml}$.

Tabla III.2. Preparación de los reactivos utilizados en el test ELISA. 


\subsubsection{Validación de la prueba ELISA e interpretación de los resultados.}

La lectura de las placas se realizó en un espectrofotómetro (EL-340 Bio-Tek Instruments ${ }^{\circledR}$ EEUU) con un filtro de $405 \mathrm{~nm}$.

El valor de absorbancia de cada suero se obtuvo, calculando la media de las densidades ópticas (DO) de cada suero problema, así como la de los controles positivos. Estos valores eran transformados en un índice que se obtenía al dividir el valor medio de la DO de cada suero entre el valor medio de los controles positivos de cada placa:

DO media 405 Muestra

Índice ELISA del suero problema = X 1000

DO media ${ }_{405}$ Control Positivo

Reaccionantes positivos a tuberculosis: índice mayor a 800

Reaccionantes dudosos a tuberculosis: índice entre 601 y 800

Reaccionantes negativos a tuberculosis: índice menor a 600

Reaccionantes positivos a paratuberculosis: índice mayor a 900

Reaccionantes dudosos a paratuberculosis: índice entre 601 y 900

Reaccionantes negativos a paratuberculosis: índice menor a 600

El punto de corte se estableció en base a los resultados de estudios previos, de tal manera que se mantuviera la mayor sensibilidad posible, con la mejor especificidad [Gutiérrez-Cancela, 1996; Pérez et al., 1997; Garrido, 2001; González, 2003]. Además de la calificación otorgada a cada animal, se reflejó también el valor del cociente en cada caso.

\subsection{Estudios post mortem.}

\subsubsection{Estudios anatomopatológicos.}

\subsubsection{Examen macroscópico y toma de muestras.}

El examen macroscópico se realizó en el total de los animales estudiados, mediante la inspección visual y palpación de varios órganos, con especial atención a la cabeza, y nódulos linfáticos asociados, pulmón y ganglios linfáticos regionales, intestino delgado y ganglios linfáticos ileocecales y mesentéricos. En los 343 animales se tomaron las muestras que se reflejan en la Tabla III.3. y Figura III.4. para su posterior estudio histológico. 


\section{Muestras recogidas}

\section{* Cabeza:}

Ganglio linfático retrofaríngeo medial (se encuentran en posición medial al asta mayor del hueso hioides, entre la faringe y los músculos rectos ventrales de la cabeza).

Ganglio linfático retrofaríngeo lateral (está situado a ambos lados de la línea media entre la laringe y el agujero magno).

Ganglio linfáticos parotídeos (localizados a cada lado de la cabeza bajo la glándula salival parótida).

\section{* Pulmón:}

Ganglio linfático traqueobronquial izquierdo (situado sobre el bronquio izquierdo, ventral al arco aórtico).

Ganglio linfático mediastínico medio (localizado al lado del traqueobronquial-izquierdo, sobre el bronquio izquierdo).

Ganglio linfático mediastínico caudal (ventral a la aorta, entre los lóbulos diafragmáticos).

\section{Intestino delgado:}

Ganglio linfático ileocecal (se encuentra junto a la válvula ileocecal).

Ganglio linfático mesentérico (se encuentra situado junto al yeyuno distal)

Tabla III.3. Identificación de las muestras tomadas, tras el sacrificio de cada animal para los diferentes estudios.
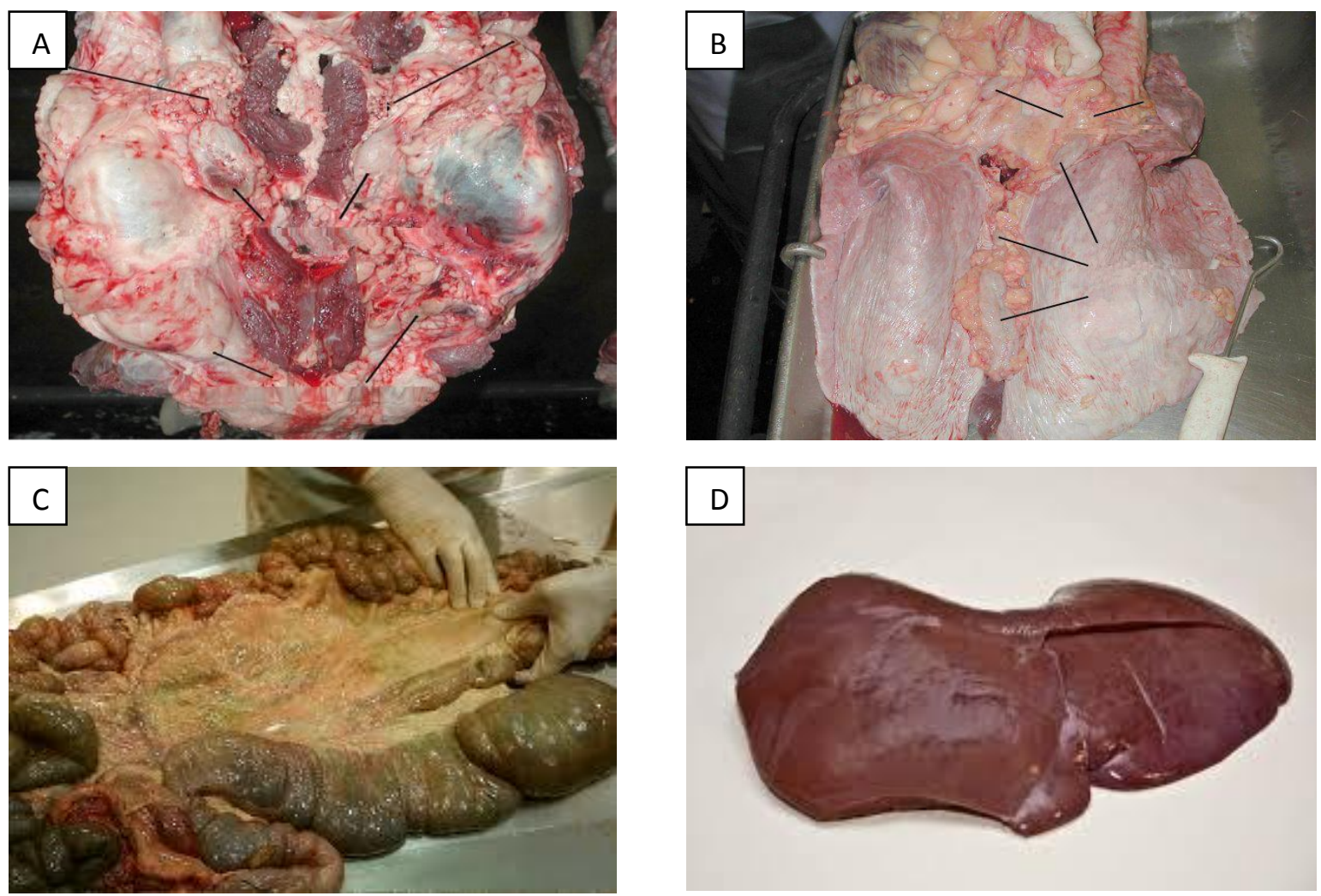

Figura III.4. Localización de los ganglios linfáticos objeto de estudio. A: Ganglios linfáticos de la cabeza. B: Ganglios linfáticos del pulmón. C: Ganglios linfáticos del intestino. D: Hígado. 
En el pulmón se procedió a su inspección visual y en los ganglios linfáticos regionales se llevó a cabo su fileteado en secciones de aproximadamente $1 \mathrm{~cm}$. En cada ganglio linfático examinado de la cabeza, se realizó también al menos una incisión. De estos órganos y de la válvula y ganglio linfático ileocecal se tomaron muestras de cada animal, que se fijaron en formol tamponado al 10\% durante 7 días a un mes, una vez identificados y etiquetados.

\subsubsection{Procesado histológico.}

Una vez fijados los ganglios linfáticos se tallaron secciones de aproximadamente 3 $\mathrm{mm}$ de espesor en busca de lesiones que hubieran podido pasar desapercibidas en el matadero. De cada muestra se tomaron dos secciones que se introdujeron en capsulas plásticas de inclusión (TESPA, Giessen, Alemania). La inclusión en parafina se realizó de forma manual durante 22 horas. Para ello se procedió al lavado en agua y deshidratación en gradientes crecientes de alcohol y xilol, seguido la inmersión en parafina de $56^{\circ} \mathrm{C}$ de punto de fusión (Vogel Histo-Comp®, Giessen, Alemania), sin realizar un montaje tradicional, ya que dichas muestras tenían que ser transportadas a España. Una vez embebidas en parafina, pero sin llegar a formar el bloque, las muestras permanecieron almacenadas durante tres meses a temperatura ambiente, para después ser trasladadas al Laboratorio de Histología y Anatomía Patología de la Facultad de Veterinaria de la Universidad de León en España donde se realizó el montaje definitivo de los bloques en una unidad formadora de bloques (Myr AP280). Una vez montados los bloques de parafina de las diferentes muestras, se realizaron secciones de $4 \mu \mathrm{m}$ de espesor mediante un micrótomo de rotación (Finesse®, Termo Shandon) que se recogieron en portaobjetos tratados con poli-L-lisina (SigmaAldrich®, Madrid, España).

En el momento de obtener secciones con el micrótomo, observamos que un buen número de bloques se cortaba con dificultad, debido a una intensa deshidratación y deficiente inclusión del tejido, probablemente por las condiciones inadecuadas de la inclusión y de almacenamiento. Por ello, los bloques se sometieron a un proceso de reinclusión, tras su rehidratación previa. Este tratamiento no tuvo éxito, siendo imposible en todas las muestras llevar a cabo secciones para estudios histológicos adecuados. Únicamente fue posible obtener secciones válidas para su examen al microscopio de muestras de 62 animales.

\subsection{Tinciones histológicas.}

Tras un secado previo de las secciones en una estufa de $37^{\circ} \mathrm{C}$ durante 24 horas se realizaron tinciones Hematoxilina-Eosina y Ziehl-Neelsen para la detección de bacilos ácido-alcohol resistentes. El estudio histológico se realizó en 62 animales que aparecen reflejados en la siguiente tabla (Tabla. III.4.). 


\begin{tabular}{|c|c|c|c|c|}
\hline $\mathbf{N}^{\circ}$ de Identif. & Municipio & Sexo & Edad & Aptitud \\
\hline M1 & San Pedro Lagunillas & o & +2 años & Carne \\
\hline B2 & Ahuacatlán & q & +2 años & Carne \\
\hline N3 & Santa María del Oro & q & +2 años & Carne \\
\hline Q4 & Tepic & $0^{\pi}$ & +2 años & Carne \\
\hline I3 & El Nayar & q & +2 años & Carne \\
\hline D1 & Compostela & q & +2 años & Carne \\
\hline S14 & La Yesca & o & +2 años & Carne \\
\hline S16 & La Yesca & q & +2 años & Carne \\
\hline S18 & La Yesca & o & +2 años & Leche \\
\hline Q5 & Tepic & $\sigma^{\pi}$ & +2 años & Carne \\
\hline M2 & San pedro Lagunillas & q & +2 años & Carne \\
\hline D5 & Compostela & q & +2 años & Carne \\
\hline D6 & Compostela & $\sigma^{\lambda}$ & +2 años & Carne \\
\hline D7 & Compostela & q & +2 años & Leche \\
\hline M3 & San Pedro Lagunillas & o & +2 años & Carne \\
\hline D9 & Compostela & q & +2 años & Carne \\
\hline D10 & Compostela & o & +2 años & Carne \\
\hline D11 & Compostela & o & +2 años & Carne \\
\hline D12 & Compostela & o & +2 años & Carne \\
\hline D13 & Compostela & o & +2 años & Carne \\
\hline C2 & Amatlán de Cañas & q & +2 años & Carne \\
\hline D15 & Compostela & q & +2 años & Carne \\
\hline N5 & Santa María del Oro & q & +2 años & Carne \\
\hline N8 & Santa María del Oro & q & +2 años & Carne \\
\hline G3 & Jala & q & +2 años & Carne \\
\hline I6 & El Nayar & o & +2 años & Carne \\
\hline I7 & El Nayar & o & +2 años & Carne \\
\hline I8 & El Nayar & o & +2 años & Carne \\
\hline I9 & El Nayar & o & +2 años & Carne \\
\hline J4 & Rosamorada & o & -2 años & Carne \\
\hline L2 & San Blas & $0^{\lambda}$ & +2 años & Carne \\
\hline F4 & Ixtlán del Río & 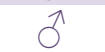 & -2 años & Carne \\
\hline N12 & Santa María del Oro & q & +2 años & Carne \\
\hline $\mathbf{E 3}$ & Huajicori & q & +2 años & Carne \\
\hline Q11 & Tepic & o & +2 años & Carne \\
\hline I12 & El Nayar & q & +2 años & Carne \\
\hline M8 & San Pedro Lagunillas & o & +2 años & Carne \\
\hline A4 & Acaponeta & o & +2 años & Carne \\
\hline B5 & Ahuacatlán & o & +2 años & Carne \\
\hline N15 & Santa María del Oro & $\sigma^{\lambda}$ & +2 años & Carne \\
\hline B7 & Ahuacatlán & o & +2 años & Carne \\
\hline A5 & Acaponeta & 우 & +2 años & Carne \\
\hline Q14 & Tepic & o & +2 años & Carne \\
\hline D20 & Compostela & 우 & +2 años & Carne \\
\hline C3 & Amatlán de Cañas & 우 & +2 años & Carne \\
\hline
\end{tabular}




\begin{tabular}{|c|c|c|c|c|}
\hline $\mathrm{C} 4$ & Amatlán de Cañas & 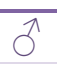 & +2 años & Carne \\
\hline S39 & La Yesca & q & +2 años & Carne \\
\hline 04 & Santiago Ixcuintla & $q$ & -2 años & Carne \\
\hline D21 & Compostela & o & +2 años & Carne \\
\hline K5 & Ruiz & q & +2 años & Carne \\
\hline N18 & Santa María del Oro & $q$ & +2 años & Carne \\
\hline A10 & Acaponeta & q & +2 años & Carne \\
\hline M9 & San Pedro Lagunillas & $q$ & +2 años & Carne \\
\hline $\mathbf{N} 20$ & Santa María del Oro & $\hat{0}$ & +2 años & Carne \\
\hline R7 & Tuxpan & q & +2 años & Carne \\
\hline O6 & Santiago Ixcuintla & q & +2 años & Carne \\
\hline S46 & La Yesca & $q$ & +2 años & Leche \\
\hline H10 & Xalisco & q & +2 años & Carne \\
\hline $\mathbf{N} 22$ & Santa María del Oro & $\hat{0}$ & +2 años & Carne \\
\hline N24 & Santa María del Oro & $q$ & +2 años & Carne \\
\hline $\mathrm{C} 8$ & Amatlán de Cañas & $\hat{0}$ & -2 años & Carne \\
\hline
\end{tabular}

Tabla III.4. Número de identificación, municipio de procedencia, sexo, edad y aptitud de los 62 animales en los que se realizó el estudio histológico.

Ambas tinciones se realizaron siguiendo los protocolos utilizados en la Universidad de León, descritos a continuación:

\section{Tinción Hematoxilina-Eosina}

- Desparafinar e hidratar pasando por xilol y alcoholes de grado decreciente.

- Lavar durante 10 minutos.

- Teñir 4 minutos en hematoxilina de Harris.

- Lavar durante 10 minutos.

- Teñir 30 segundos en eosina.

- Lavar durante 30 segundos introduciendo los portaobjetos en 2 recipientes.

- Deshidratar con alcoholes de grado creciente y xilol.

- Montaje con DPX (BDH ®, Reino Unido).

Tabla III.5. Protocolo de la tinción Hematoxilina-Eosina (H-E).

\section{Reactivos para la tinción Hematoxilina-Eosina}

\section{Hematoxilina de Harris.}

Hematoxilina (Merck®, Darmstadt, Alemania): 1 gr.

Alcohol 100: $10 \mathrm{ml}$.

Alumbre amónico (Merck®, Darmstadt, Alemania): 20 gr.

Agua destilada: $200 \mathrm{ml}$.

Óxido de mercurio (Merck®, Darmstadt, Alemania): 0,5 gr.

* Eosina.

Eosina (Merck®, Darmstadt, Alemania): 1 gr.

Agua destilada: $100 \mathrm{ml}$.

Ácido acético glacial al 100\%: 2-3 gotas.

Tabla III.6. Reactivos empleados para la tinción Hematoxilina-Eosina (H-E). 


\section{Tinción Ziehl-Neelsen}

- Desparafinar e hidratar con xilol y alcoholes de grado decreciente.

- Lavar durante 10 minutos.

- Solución de carbol-fucsina 1 hora a temperatura ambiente.

- Lavar durante 5 minutos.

- Decolorar con la solución de alcohol-ácido hasta que la preparación se haga rosa pálida.

- Lavar durante 8 minutos.

- Colorear con la solución de trabajo azul de metileno 15 segundos.

- Lavar en agua de grifo y luego en agua destilada.

- Deshidratar pasando por alcoholes de grado creciente y xilol.

- Montar con DPX (BDH ®, Reino Unido).

Tabla III.7. Protocolo para la tinción Ziehl-Neelsen (Z-N).

\section{Reactivos empleados en la tinción Ziehl-Neelsen}

* Coloración:

Carbolfucsina.

\section{Decoloración:}

Alcohol de $70^{\circ}: 100 \mathrm{ml}$.

Ácido clorhídrico.

Contraste:

Solución madre de Azul de Metileno:

Azul de metileno.

Alcohol de 95 : $100 \mathrm{ml}$

Solución de trabajo de Azul de Metileno:

Solución madre de azul de metileno: $10 \mathrm{ml}$.

Agua corriente: $90 \mathrm{ml}$.

Tabla III.8. Reactivos empleados para la tinción Ziehl-Neelsen (Z-N).

\subsubsection{Valoración de las lesiones.}

La valoración macroscópica de las lesiones tuberculosas en ganado bovino se realizó atendiendo la descripción clásica de los textos [Pallaske, 1962; Nieberle y Cohrs, 1966].

En el caso de las lesiones microscópicas asociadas a tuberculosis, se tomó como referencia para la clasificación lesional los tipos propuestos por García Castro (2007), que reconoce los tipos que se explican brevemente a continuación: 
Tipo I:

En algunos ganglios se observó la presencia de pequeños granulomas (tubérculos miliares y submiliares) formados por macrófagos, células gigantes de Langhans muy diferenciadas, de gran tamaño y numerosos núcleos. Estos granulomas estaban bien delimitados del tejido circundante pero sin presencia de encapsulación. Cuando el tamaño de los mismos era mayor comenzaban a observarse zonas de necrosis de mayor tamaño delimitadas por linfocitos, macrófagos y abundantes células gigantes bien diferenciadas. En el seno de esta necrosis eran abundantes los restos celulares y apenas se observaba calcificación. La extensión de las lesiones era variable, con tendencia a localizarse en la zona interfolicular preservándose la mayor parte de los folículos y zona medular.

Tipo II:

La lesión era semejante a la anterior, pero con un número moderado de células gigantes de diferente tamaño y localizadas en la periferia de los granulomas. Asimismo, en algunas zonas de esta necrosis se apreciaba el inicio de una fina cápsula fibrosa. Junto con estas lesiones se observaban también áreas de necrosis con calcificación más extensas y delimitadas por una cápsula fibrosa y muy escaso componente celular, siendo la cantidad de células gigantes esporádica.

Tipo III:

Era característica la presencia de focos de necrosis de tamaño variable, con intensa calcificación y delimitados por una gruesa y densa cápsula fibrosa en la que habitualmente no se observaban células gigantes, siendo esporádicas y de pequeño tamaño cuando aparecían en la lesión, conformando un tejido semejante al de granulación. El número de estos focos era variable en cada caso, destruyéndose completamente la estructura del ganglio linfático en las zonas donde se localizaba.

En el caso de la paratuberculosis, para la valoración de las lesiones microscópicas se utilizaron los criterios propuestos por González et al. (2005) que, en función de su extensión y las características morfológicas, las clasifica en focales formadas por pequeños granulomas en el tejido linfoide, multifocales cuando también aparecían en la lámina propia, y difusas cuando el infiltrado ocupaba amplias zonas del intestino.

\subsection{Detección de micobacterias mediante PCR y selección de muestras.}

La detección del genoma micobacteriano de M. bovis y Map se realizó en 275 animales, empleando la técnica de reacción en cadena de la polimerasa (PCR), un conjunto o "pool" de muestras de cada animal. En otros 14 animales, en muestras individuales 
elegidas en función de la presencia de lesiones, se realizó una PCR para la detección de ácido nucleicos de $M a a$, en ambos casos las muestras habían sido fijadas en formol, por un periodo de tiempo de aproximadamente 7 días e incluidas en parafina.

\subsubsection{Procesado de las muestras.}

Dichas secciones se obtuvieron mediante un micrótomo de rotación de forma que, entre cada bloque de parafina se procedía a la limpieza del micrótomo y de la cuchilla con lejía al 19\% para evitar contaminaciones de ADN y con xilol para eliminar restos de parafina. Se utilizó una cuchilla por cada 3 animales (lado derecho, centro y lado izquierdo). Las secciones se colocaron en tubos de 1,5 ml. estériles y libres de DNAsas con la ayuda de unas pinzas estériles.

Como controles positivos, se emplearon bloques de tejido incluidos en parafina, de muestras de vacas ya conocidas de antemano por ser positivas a Map, M. bovis o Maa. Las secciones de los controles positivos se obtuvieron independientemente.

\subsubsection{Lisis de la micobacteria y extracción del ADN.}

\section{Frente a M. bovis y Map ("pool").}

Para la extracción de las micobacterias, las muestras se centrifugaron durante 3 minutos a $7500 \mathrm{rpm}$ para compactar. A cada muestra se le agregaron $200 \mu \mathrm{m}$ de Tween 20 $(0,5 \%)$. Después procedimos a la lisis empleando el método de rotura de las micobacterias por congelación/descongelación descrito por Garrido (2001), por el cual, los viales se sometieron a temperaturas de $100^{\circ} \mathrm{C}$ durante 10 minutos en una placa térmica para sumergirlas a continuación en nitrógeno líquido durante 10 minutos. Este proceso se repitió dos veces para la detección del genoma micobacteriano de Map y M. bovis.

A continuación, se introdujeron a la centrífuga a $5500 \mathrm{rpm}$ durante 20 minutos. Para finalizar se recogieron aproximadamente entre 40 y $80 \mu 1$ del sobrenadante sin parafina. Las muestras se congelaron a $-20^{\circ} \mathrm{C}$ hasta la realización de la PCR.

\section{Extracción y lisis del ADN mediante el kit comercial.}

Frente a M. bovis, Map y Maa (individual).

La extracción y lisis de ADN se realizó siguiendo las instrucciones del fabricante. Los componentes del kit de extracción se almacenaron a temperatura ambiente (con la excepción de la proteinasa $\mathrm{K}$ que se conservaba en refrigeración a $4^{\circ} \mathrm{C}$ ) y vienen descritos en la tabla III.9. 


\section{Componentes del kit comercial Speedtools Tissue DNA extraction kit ${ }^{\circledR}$}

* Buffer BT1 (Contiene hidrocloruro de guanidina)

* Proteinasa K (Liofilizada): $30 \mathrm{mg}$.

* Buffer proteinasa: $1,8 \mathrm{ml}$.

-Al abrir el kit la primera vez se tiene que reconstruir la proteinasa $\mathrm{K}$ liofilizada con 1,35 $\mathrm{ml}$ de Buffer proteinasa.

* Reactivo BB1: $10 \mathrm{ml}$.

* Reactivo BB2: $2,5 \mathrm{ml}$.

-Al abrir el kit se transfiere todo el contenido del Buffer BB1 en el reactivo BB2, se mezcla y la solución restante se convierte en el Buffer BB3 (contiene hidrocloruro de guanidina).

* Buffer BBW: (Contiene hidrocloruro de guanidina): $30 \mathrm{ml}$.

* Buffer BB5: (Concentrado): $7 \mathrm{ml}$.

-Al abrir el kit la primera vez se diluye este buffer en $28 \mathrm{ml}$ de etanol.

Buffer de elución BBE (Tris/HCL 5mM, pH 8,5): $13 \mathrm{ml}$. No contiene EDTA en su composición.

\section{* Columnas de unión ADN}

* Tubos de 2 ml.

Tabla.III.9. Componentes del kit comercial Speedtools Tissue DNA extraction kit (Biotools® B\&M Labs., S.A., Madrid, España) para la extracción y purificación de ADN.

Tras añadir $180 \mu 1$ de Buffer BT1 y $25 \mu 1$ de proteinasa $\mathrm{K}$, se incubaron las muestras en baño maría a $56^{\circ} \mathrm{C}$ durante $2-3 \mathrm{~h}$, homogeneizándolas ocasionalmente con ayuda de un agitador vórtex, hasta alcanzar una digestión completa del tejido. Con el fin de romper las células, completar la lisis de las muestras y así poder extraer y purificar el ADN, se dispensaron $200 \mu 1$ de Buffer BB3 de lisis, homogeneizado nuevamente las muestras mediante vórtex e incubándolas a $70^{\circ} \mathrm{C}$ durante $10 \mathrm{~min}$. Tras una centrifugación a 13000 rpm durante 5 min. Para precipitar el resto de partículas insolubles, se transfirió el sobrenadante a un nuevo vial de $1,5 \mathrm{ml}$ para PCR.

La extracción de ADN se realizó mediante el uso de columnas de unión de ADN previamente colocadas sobre tubos de PCR de $2 \mathrm{ml}$ (incluidos en el kit). Para ello, tras añadir $210 \mu \mathrm{l}$ de etanol (Probalo ${ }^{\mathrm{TM}}$, Briare, Francia) al lisado y mezclar por inversión, se cargó la muestra a su columna correspondiente, que fue centrifugada durante $90 \mathrm{seg}$ a $13000 \mathrm{rpm}$ para favorecer la unión del ADN a la membrana de sílica. A continuación se procedió al lavado de dicha membrana con el fin de eliminar cualquier impureza. Así, se realizó un primer lavado con $500 \mu \mathrm{l}$ de Buffer BBW y, tras centrifugar durante 90 seg a 13000 rpm, se llevó a cabo un segundo lavado con $600 \mu$ l de Buffer BB5 y centrifugado durante 2 min. A la misma velocidad. Para eliminar el etanol residual, se procedió al secado de la membrana con el ADN adherido, centrifugado durante 2 min a $13000 \mathrm{rpm}$.

Finalmente se llevó a cabo la elución del ADN puro, transfiriendo la columna vial de 1,5 ml estéril y libre de ADNasas y dispensando $50 \mu \mathrm{l}$ de Buffer BBE precalentado a 
$70^{\circ} \mathrm{C}$ directamente en la membrana (sin llegar a tocarla). Se incubaron las muestras durante 3 min y finalmente se centrifugaron 2 min a $13000 \mathrm{rpm}$ para recoger el ADN puro extraído en el vial de 1,5 ml. Se volvió a repetir el paso de elución en las mismas condiciones, de tal forma que el ADN recogido acabó diluido en $100 \mu 1$ de Buffer BBE. A continuación, o bien se pasaba directamente a la fase de amplificación del ADN, o bien se almacenaban las muestras a $-20^{\circ} \mathrm{C}$ hasta su posterior uso.

\title{
3.5.3. Amplificación del ADN micobacteriano.
}

La amplificación del ADN se realizó en un termociclador XP Thermal Cycler® (Bioer Technology Co., LTD, Japón). Las secuencias de los oligonucleótidos de los cebadores utilizados para la amplificación del ADN micobacteriano se detallan a continuación [Collins et al., 1993b]:

Para amplificar un fragmento de 217 pares de bases (pb) IS900 especifico de Map sometiendo a las muestras al siguiente protocolo:

\author{
*Desnaturalización: $96^{\circ} 3$ min. \\ *Amplificación: 40 ciclos. \\ 'Desnaturalización: $96^{\circ} 1 \mathrm{~min}$. \\ ${ }^{\circ}$ Cebado: $65^{\circ} 1 \mathrm{~min}$. \\ ${ }^{\circ}$ Extensión: $72^{\circ} 2 \mathrm{~min}$. \\ *Extensión: $72^{\circ} 8 \mathrm{~min}$. \\ C1: GAT CGG AAC GTC GGC TGG TCA GG \\ C2: GAT CGC CTT GCT CAT CGC TGC CG
}

Para amplificar un fragmento de 123 pares de bases (pb) IS6110 especifico del complejo M. tuberculosis, empleando el siguiente ciclo de temperaturas y tiempos:

*Desnaturalización: $94^{\circ} 1 \mathrm{~min}$.

*Amplificación: 50 ciclos.

${ }^{\circ}$ Desnaturalización: $94^{\circ} 45 \mathrm{seg}$.

${ }^{\circ}$ Cebado: $72^{\circ} 75 \mathrm{seg}$.

${ }^{\circ}$ Extensión: $72^{\circ} 10 \mathrm{~min}$.

*Extensión: $\left.72^{\circ} 8 \mathrm{~min}\right)$.

TB1: CTC GTC CAG CGC CGC TTC GG

TB2: CCT GCG AGC GTA GGC GTC GG

Para amplificar un fragmento de 257 pares de bases (pb) IS901 especifico del complejo M. avium avium, empleando el siguiente ciclo de temperaturas y tiempos:

*Desnaturalización: $94^{\circ} 10 \mathrm{~min}$.

*Amplificación: 50 ciclos.

'Desnaturalización: $94^{\circ} 1 \mathrm{~min}$. 


\author{
${ }^{\circ}$ Cebado: $65^{\circ} 15 \mathrm{seg}$. \\ ${ }^{\circ}$ Extensión: $72^{\circ} 75 \mathrm{seg}$. \\ *Extensión: $72^{\circ} 8 \mathrm{~min}$. \\ MAA1: AAG CCG AGG TGG TGT ATG T \\ MAA2: AGG GAA GAT GGC GGT GAG CAT
}

Para llevar a cabo este proceso, se preparaba una "pre-mezcla" de amplificación, utilizando los siguientes reactivos descritos en la siguiente tabla III.10.

\begin{tabular}{cccc}
\hline Reactivos & $\begin{array}{c}\text { Concentración } \\
\text { Inicial }\end{array}$ & $\begin{array}{c}\text { Volumen } \\
(\mu \mathrm{l}) / \text { muestra Tb }\end{array}$ & $\begin{array}{c}\text { Volumen } \\
(\mu \mathrm{l}) / \text { muestra Ptb }\end{array}$ \\
\hline $\begin{array}{c}\mathbf{H}_{2} \mathbf{O} \\
\text { Buffer (5Prime } \\
\text { Inc.; EEUU) }\end{array}$ & $10 \mathrm{X}$ & 13,3 & 14,3 \\
$\begin{array}{c}\text { Mezcla de dNTPs } \\
\text { (Bioline®; Reino } \\
\text { Unido) }\end{array}$ & $2,5 \mathrm{mM}$ & 2,5 & 2,5 \\
$\begin{array}{c}\text { Primer's } \\
\text { (Invitrogen; }\end{array}$ & $20 \mu \mathrm{M}$ & 2 & 2 \\
EEUU) & & $\mathrm{Tb}_{1} 1$ & $\mathrm{C}_{1} 0,5$ \\
$\begin{array}{c}\text { Taq ADN } \\
\text { polimerasa (5Prime } \\
\text { Inc.; EEUU) }\end{array}$ & $5 \mathrm{U} / \mu \mathrm{M}$ & & \\
ADN muestra & & $\mathrm{Tb}_{2} 1$ & $\mathrm{C}_{2} 0,5$ \\
Total & & & 0,2 \\
\hline
\end{tabular}

Tabla III.10. Reactivos empleados en la fase de amplificación de la PCR para las secuencias de inserción IS900 de Map, IS6110 de M. bovis e IS901 de Maa.

La pre-mezcla se preparó en un cuarto destinado únicamente a este uso, el cual está provisto de una lámpara de luz ultravioleta que, se encendía siempre aproximadamente 20 minutos antes de cada sesión de trabajo, con la finalidad de degradar cualquier ADN presente en las instalaciones, puntas, pipetas o en los mismos reactivos.

El paso siguiente fue introducir $20 \mu 1$ de esta pre-mezcla de amplificación en unos viales de $0,2 \mathrm{ml}$ de paredes estériles y libres de ADNasas (VWR collection ${ }^{\circledR}$ ). En otro habitáculo diferente se añadieron $5 \mu \mathrm{l}$ de ADN de las muestras problemas a esta premezcla. Para asegurar que el proceso de amplificación de ADN fuera el correcto, se incluyó un control "positivo" ya conocido y otro "negativo", sin ADN añadido (H2O Milli Q) para cada reacción de PCR. Por último los viales se colocaron simétricamente en el termociclador y eran sometidos a los ciclos antes señalados. 
Finalmente, las muestras obtenidas se refrigeraron a $4^{\circ} \mathrm{C}$ para conservarlas hasta llevar a cabo el proceso de identificación del producto amplificado mediante electroforesis.

\subsubsection{Identificación del segmento amplificado.}

Este proceso se realizó en un cuarto y con material exclusivo para trabajar específicamente con "amplicones". Los fragmentos de ADN amplificados tras la PCR se visualizaron mediante electroforesis en un gel de agarosa (SeaKem®LE Agarose, Iberlabo, S.A., Madrid, España) al 3\% en tampón TBE 0,5X. Los reactivos y el proceso de elaboración se describen en la siguiente tabla (Tabla III.11.).

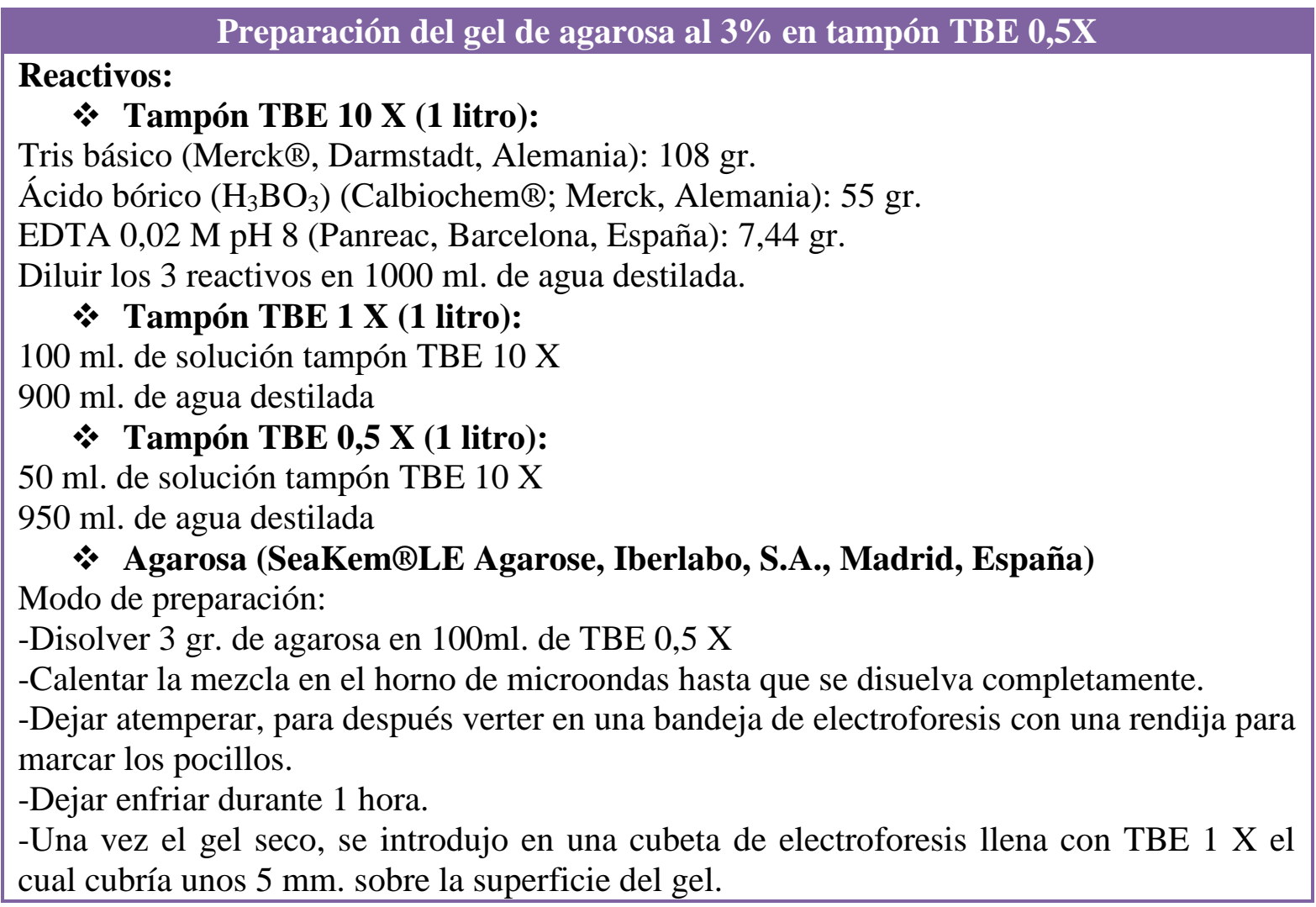

Tabla III.11. Reactivos y protocolo de preparación del gel de agarosa para la visualización de los fragmentos de ADN amplificados. 
Una vez que el gel se encontraba en la cubeta de electroforesis, procedimos a colocar unas serie de "huellas circulares" sobre la superficie de papel parafinado (Parafilm ${ }^{\circledR}$ ), donde se mezclaron mediante suaves pipeteos, $10 \mu \mathrm{l}$ de la muestra problema obtenida tras la amplificación y $5 \mu 1$ de azul de bromofenol con ARNasas (Ecogen®, Madrid, España) en agua destilada libre de ADNasas y estéril, como tampón de carga. Finalmente se cargó el gel con los $15 \mu 1$ en su pocillo correspondiente. Este proceso fue el mismo para cada muestra, incluidos el control positivo y negativo.

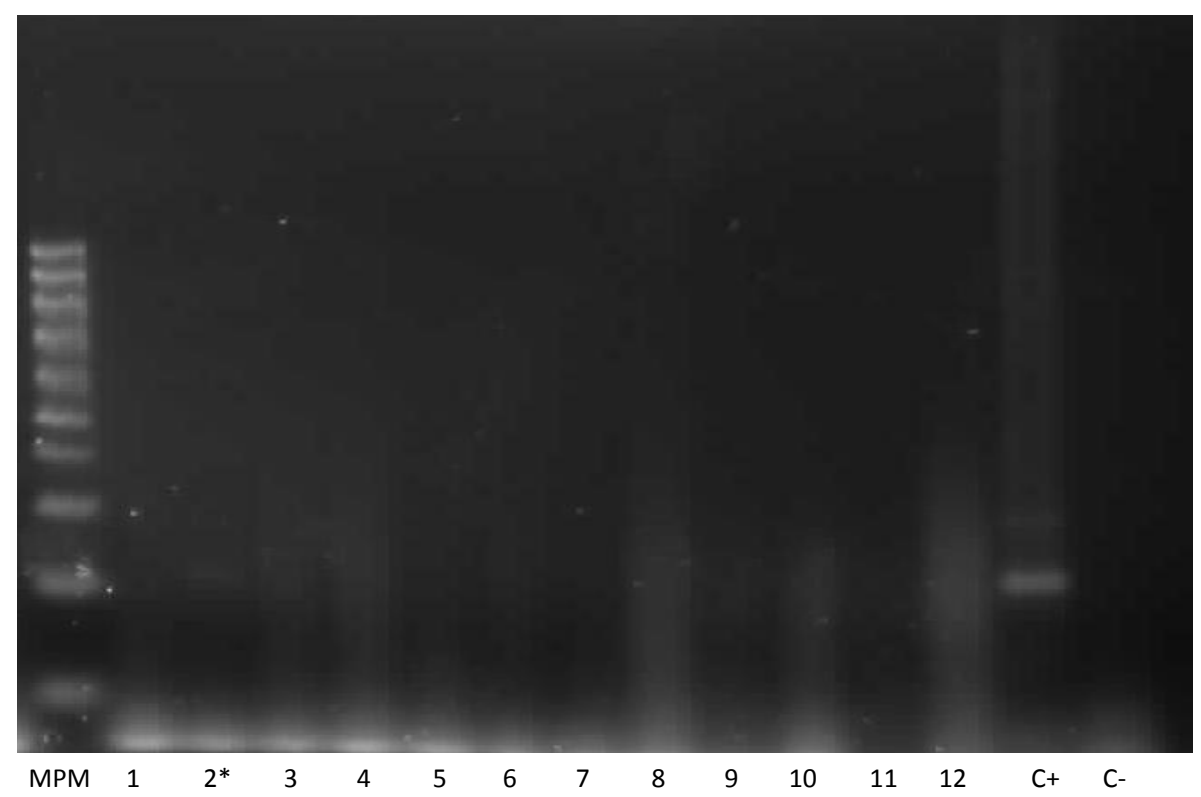

C+: Control positivo.

C-: Control negativo.

Muestra positiva: $2^{*}$

Muestras negativas: $1,3,4,5,6,7,8,9$, 10,11 y 12 .

MPM: Marcador de peso molecular.

Figura III.5. Revelado de la PCR en gel de agarosa.

A continuación el gel fue sometido a una corriente eléctrica de $90 \mathrm{~V}$ al conectar la cubeta de electroforesis durante aproximadamente 90 minutos hasta que la banda azul de las muestras llegaba a pocos centímetros antes del borde del gel. Seguidamente el gel se tiñó en un baño en agitación con una solución de $0,5 \mu \mathrm{g} / \mathrm{ml}$ de azul de bromofenol (Merck®, Darmstadt, Alemania) durante 30 minutos. Finalmente, se realizó la lectura en una cámara con luz ultravioleta a $240 \mathrm{~nm}$ conectada a un sistema informático de tratamiento de imágenes (BioCapt MW1).

La interpretación de los resultados se llevó a cabo tras comprobar que en las muestras positivas aparecía una banda fluorescente de 123, 217 y 257 pb, correspondientes al fragmento amplificado de la secuencia de inserción IS6110, IS900 y IS901 respectivamente. 


\section{III.4. MATERIAL ÓPTICO Y FOTOGRÁFICO.}

Para el estudio de las secciones histológicas se empleó un microscopio Leitz Diaplan con cabezal múltiple de discusión y con óptica PL Fluotar, alternando entre los distintos objetivos de 4X. 10X, 25X, 40X y 63X según el caso. Las microfotografías se realizaron en un microscopio Olympus Provis Ax70 (Tokio, Japón) con una cámara digital Nikon Digital Camera DMX 1200.

Para la realización de las fotografías macroscópicas se empleó una cámara digital Fujifilm FinePix Z33WP.

\section{III.5. MATERIAL INFORMÁTICO Y ANÁLISIS ESTADÍSTICO.}

Los programas informáticos empleados para la realización de este estudio fueron el Word, como procesador de textos, el Excel como hoja de cálculos y para obtención de gráficos, ambos del paquete Microsoft Office $2010^{\mathrm{TM}}$. Además, el análisis de datos obtenidos mediante PCR se realizó a través de los programas MJ Opticon Monitor $3^{\mathrm{TM}}$ Analysis Software (Biorad, CA, EEUU) y Qbaseplus (Biogazelle@ $\odot$, Ghent, BE). Por último, se empleó el programa informático Win Episcope Ver. 2.0 para la obtención del grado de concordancias entre pruebas diagnósticas y la prueba estadística de chi-cuadrado para la comparación de proporciones, con un nivel de confianza del 95\% en ambos casos.

Para la valoración de la concordancia entre pruebas se utilizó la variable estadística kappa, cuyos valores pueden oscilar entre $-1 \mathrm{y}+1$, donde +1 indica concordancia total, -1 equivale a la discordancia total, mientras que 0 indica que la concordancia observada es debida exclusivamente al azar. Por convención, los valores comprendidos entre 0 y 0,2 indican una concordancia débil; aquellos entre 0,2 y 0,4 se interpretan como concordancia escasa; entre 0,4 y 0,6 concordancia moderada; entre 0,6 y 0,8 concordancia significativa y finalmente valores de kappa entre 0,8 y 1 sugieren una concordancia casi perfecta (Smith, 1995). 


\section{IV.RESULTADOS}

"Aprender es como remar contra corriente: en cuanto se deja, se retrocede"

Edward Benjamin Britten (1913-1976). 


\section{IV.1. VALORACION DE LA RESPUESTA INMUNE PERIFÉRICA FRENTE A TUBERCULOSIS Y PARATUBERCULOSIS.}

En la Tabla IV.26 (pág. 105). se relacionan los animales estudiados así como los resultados de las pruebas diagnósticas realizadas.

\subsection{Pruebas de inmunidad celular.}

\subsubsection{Intradermorreacción simple bovina.}

Como ya se ha mencionado en el capítulo de Materiales y Métodos, la prueba de intradermorreacción (IDR) simple con PPD bovina se realizó en un total de 289 animales, de los cuales 26 (8.99\%) se consideraron como positivos según los criterios expuestos en el capítulo II-4.4.1.1, al producirse un incremento de grosor superior a $4 \mathrm{~mm}$ del pliegue anocaudal donde se inoculó la PPD bovina, mientras que 263 animales $(91,01 \%)$ se consideraron negativos al no producirse ningún incremento (Fig. IV.1).

\section{Resultados de la IDR bovina}

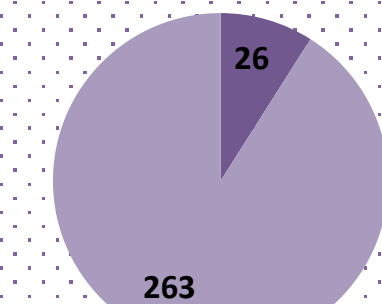

Positivos $(8,99 \%)$

Negativos $(91,01 \%)$

263

Gráfico IV.1. Resultados en la prueba de IDR bovina sobre 289 animales.

Dichos positivos se distribuían en los grupos A, B, D, E, H, I, J, K, M, N, O, Q, S y $\mathrm{T}$ con $18,18 \%, 9,09 \%, 12,5 \%, 8,33 \%, 9,09 \%, 5,26 \%, 14,28 \%, 28,57 \%, 6,66 \%, 9,52 \%$, $16,66 \%, 6,45 \%, 11,62 \%$ y $14,28 \%$ de reaccionantes positivos respectivamente, siendo el porcentaje global de positividad de estos 14 grupos de 12,17\% (Tabla IV.1.).

Cuando se llevó a cabo la prueba de chi-cuadrado de comparación de proporciones, no se observaron diferencias significativas en el nivel de prevalencia entre grupos $(\mathrm{p}=$ 0,99). 


\begin{tabular}{|cccc|}
\hline Grupo (Municipio) & $\mathbf{N}^{\circ}$ Animales & $\mathbf{N}^{\circ}+$ & $+\%$ \\
\hline A & 11 & 2 & 18,18 \\
B & 11 & 1 & 9,09 \\
D & 24 & 3 & 12,5 \\
\hline E & 12 & 1 & 8,33 \\
H & 11 & 1 & 9,09 \\
\hline I & 19 & 1 & 5,23 \\
\hline J & 14 & 2 & 14,28 \\
K & 7 & 2 & 28,57 \\
M & 15 & 1 & 6,66 \\
\hline N & 21 & 2 & 9,52 \\
\hline O & 6 & 1 & 16,66 \\
$\mathbf{Q}$ & 31 & 2 & 6,45 \\
S & 43 & 5 & 11,62 \\
\hline T & 7 & 1 & 14,28 \\
\hline TOTAL & 232 & 25 & 10,77 \\
\hline
\end{tabular}

Tabla IV.1. Resultado de los grupos a la prueba de intradermorreacción. $\mathrm{N}^{\circ}$ Animales: Total de animales de cada grupo. $\mathrm{N}^{\circ}+$ : Numero de reaccionantes positivos a la PPD bovina; \%+: Porcentaje de reaccionantes positivos a la PPD bovina.

\subsection{Prueba de inmunidad humoral.}

\subsubsection{Test de ELISA.}

\section{Tuberculosis:}

La prueba ELISA, se realizó en un total de 320 animales (Gráfico IV.1.), 16 de ellos $(5 \%)$ se consideraron positivos intenso $(++)$ al presentar un índice superior a 1000, 42 animales $(13,12 \%)$ resultaron positivos moderados $(+)$ con un índice entre 801 y 1000 , mientras que 149 animales $(46,56 \%)$ resultaron dudosos ya que el índice serológico osciló entre 501 y 800 . Por último, 113 animales (35,31\%), se consideraron negativos ya que el índice serológico fue inferior a 500 (Tabla IV.2.).

\section{Paratuberculosis:}

La prueba ELISA para paratuberculosis se realizó en 320 animales (Gráfico IV.1.), 20 de ellos $(6,25 \%)$ se consideraron positivos intenso (++) al presentar un índice superior a 1000, 11 animales $(3,43 \%)$ resultaron positivos moderado $(+)$ con un índice entre 901 y 1000, mientras que $71(22,18 \%)$ fueron dudosos, con un índice serológico entre 601 y 900. 
Por último, 218 animales $(63,55 \%)$ resultaron negativos ya que el índice serológico fue inferior a 600 (Tabla IV.2.).

\begin{tabular}{ccccccc}
\hline & \multicolumn{5}{c}{ Map } \\
\cline { 2 - 6 } GRUPO bovis & $(++)$ & $(+)$ & $(+/-)$ & $(++)$ & $(+)$ & $(+/-)$ \\
A & 0 & $2(18,18 \%)$ & $5(45,45 \%$ & 0 & $1(9,09 \%)$ & $2(18,18 \%)$ \\
B & 0 & $1(8,33 \%)$ & $4(33,33 \%)$ & $1(8,33 \%)$ & $1(8,33 \%)$ & $2(16,66 \%)$ \\
C & $1(12,5 \%)$ & 0 & $4(50 \% 9$ & 0 & $2(25 \%)$ & $1(12,5 \%)$ \\
D & $2(6,90 \%)$ & $1(3,45 \%)$ & $18(62,05 \%)$ & $1(3,44 \%)$ & $1(3,44 \%)$ & $7(24,13 \%)$ \\
E & 0 & $1(10 \%)$ & $6(60 \%)$ & $1(10 \%)$ & $1(10 \%)$ & 0 \\
F & 0 & $1(10 \%)$ & $5(50 \%)$ & $1(10 \%)$ & 0 & $1(10 \%)$ \\
G & 0 & $3(30 \%)$ & $4(40 \%)$ & 0 & $1(10 \%)$ & $2(20 \%)$ \\
H & $1(9,09 \%)$ & $2(18,18 \%)$ & $7(63,63 \%)$ & $1(9,09 \%)$ & 0 & 0 \\
I & 0 & $3(14,28 \%)$ & $8(38,09 \%)$ & $1(4,76 \%)$ & 0 & $5(23,80 \%)$ \\
J & $3(18,75 \%)$ & $2(12,5 \%)$ & $6(37,5 \%)$ & 0 & 0 & $4(25 \%)$ \\
K & 0 & $2(20 \%)$ & $4(40 \%)$ & $1(10 \%)$ & $1(10 \%)$ & $4(40 \%)$ \\
L & 0 & $2(25 \%)$ & $3(37,5 \%)$ & 0 & $1(12,5 \%)$ & $2(25 \%)$ \\
M & 0 & $5(33,33 \%)$ & $7(46,66 \%)$ & $2(13,33 \%)$ & $2(13,33 \%)$ & $4(26,66 \%)$ \\
N & $4(16 \%)$ & $3(12 \%)$ & $4(16 \%)$ & $1(4 \%)$ & 0 & $8(32 \%)$ \\
O & 0 & $2(22,22 \%)$ & $2(22,22 \%)$ & $1(11,11 \%)$ & $1(11,11 \%)$ & $3(33,33 \%)$ \\
P & $1(5,88 \%)$ & $2(11,76 \%)$ & $11(64,70 \%)$ & $1(5,88 \%)$ & $2(11,76 \%)$ & $4(23,52 \%)$ \\
Q & 0 & $5(15,62 \%)$ & $14(43,75 \%)$ & $1(3,12 \%)$ & $2(6,25 \%)$ & $5(15,62 \%)$ \\
R & $3(25 \%)$ & 0 & $9(75 \%)$ & 0 & $1(8,33 \%)$ & $4(33,33 \%)$ \\
S & $1(2,12 \%)$ & $3(6,38 \%)$ & $23(48,93 \%)$ & $2(4,25 \%)$ & 0 & $9(19,14 \%)$ \\
T & 0 & $2(28,57 \%)$ & $5(71,43 \%)$ & 0 & 0 & $3(42,85 \%)$ \\
TOTAL & $16(5 \%)$ & $42(13,12 \%)$ & $149(46,56 \%)$ & $15(4,68 \%)$ & $17(5,31 \%)$ & $75(23,43 \%)$ \\
\hline T
\end{tabular}

Tabla IV.2. Resultado del test ELISA frente a M. bovis y a Map. 


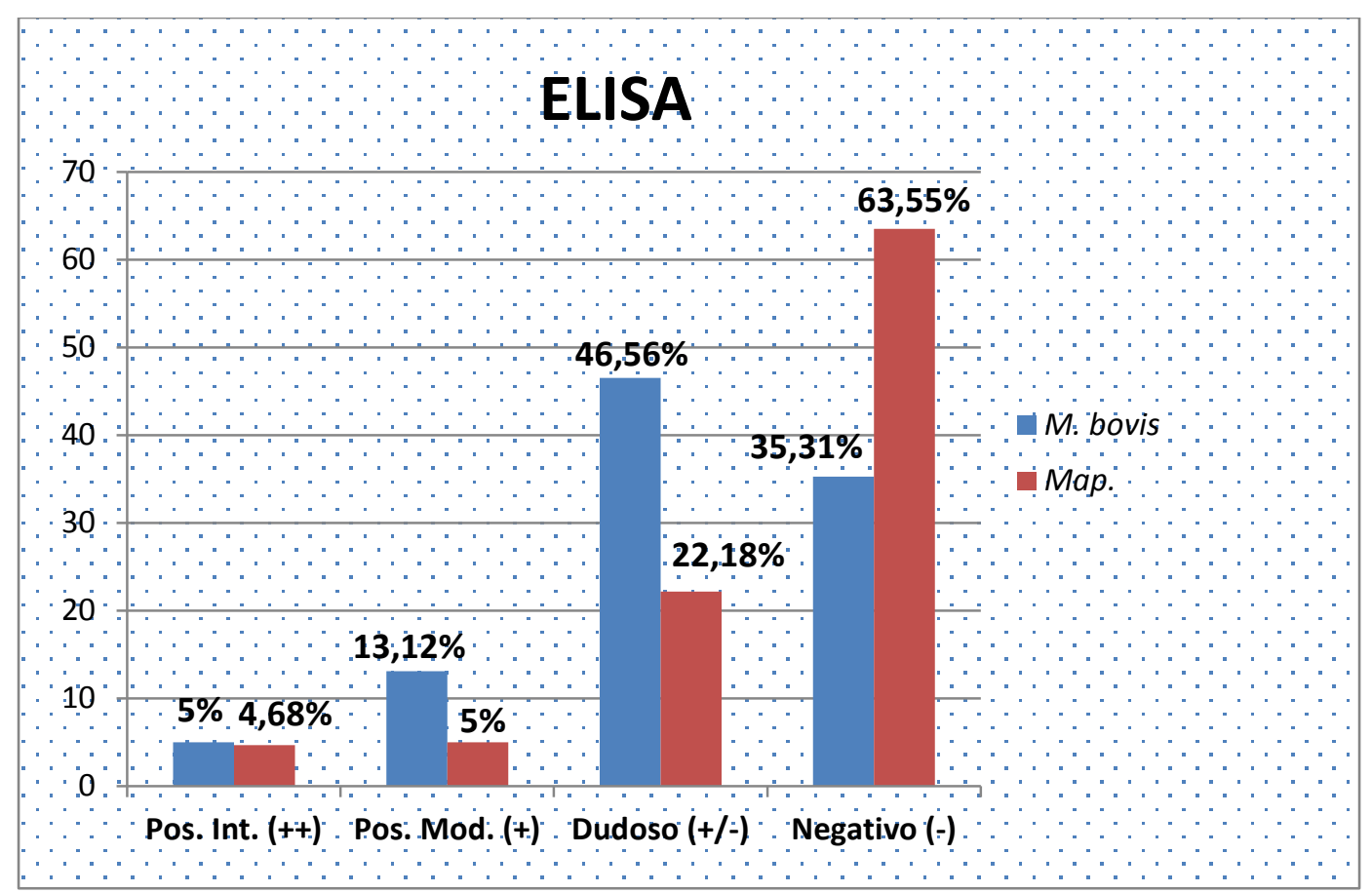

Gráfico IV.2. Resultados del test ELISA sobre 320 animales.

Los grupos que presentaron un porcentaje de positividad mayor del $25 \%$ fueron 8: $\mathrm{G}$ (30\%), H (27,27\%), J (31,25\%), L (25\%), M (33,33\%), N (28\%), R (25\%) y T (28,57\%). El porcentaje global de positividad de los 14 grupos fue del $28,84 \%$.

Los reaccionantes positivos se distribuían en su mayoría en los grupos B (25\%), C (25\%), E (20\%), K (20\%), M (26,67\%) y O (22,22\%). El porcentaje en el conjunto de los grupos ascendía a $23,14 \%$.

De acuerdo a la edad los animales, éstos se dividieron en dos grupos, como ya se mencionó en el capítulo de Materiales y Métodos: animales menores de 2 años y animales mayores de 2 años. La prueba ELISA, se realizó en 47 animales menores de dos años, obteniéndose los resultados que se exponen en la tabla IV.3. Cuando se analizaron los datos mediante la prueba de chi-cuadrado, no se encontró una asociación entre el nivel de positividad y la edad de los animales para ninguna de las técnicas.

\begin{tabular}{llll}
\hline GRUPO & $\mathbf{N}^{\circ}$ Animales & + TB & +PTB \\
\hline$\leq 2$ años & 47 & $11(23,40 \%)$ & $6(12,76 \%)$ \\
$\geq 2$ años & 273 & $47(17,21 \%)$ & $25(9,15 \%)$ \\
TOTAL & 320 & $58(18,12 \%)$ & $31(9,68 \%)$ \\
\hline
\end{tabular}

Tabla. IV.3. Resultado del test ELISA frente a M. bovis y Map por edad. $\mathrm{N}^{\circ}$ Animales: Número total de animales. +TB: Número de animales positivos al test ELISA frente a M. bovis. +PTB: Número de animales positivos al test ELISA frente a Map. 


\section{Tuberculosis.}

De los 47 animales menores de 2 años, 5 de ellos (10,63\%) se consideraron positivos intensos (++) al presentar un índice superior a 1000, 6 animales $(12,76 \%)$ se consideraron positivos moderados (+) al presentar un índice mayor a 800 y menor de 1000, mientras que 20 animales $(45,55 \%)$ resultaron dudosos ya que el índice serológico osciló entre 501 y 800 . Por último, 16 animales (34,01\%), se consideraron negativos ya que el índice serológico fue inferior a 500. En los mayores de dos años la prueba de ELISA se realizó en 273 animales, de los cuales, 46 (16,84\%) se consideraron positivos al presentar un índice superior a 801 , mientras que 127 animales $(46,52 \%)$ resultaron dudosos ya que el índice serológico osciló entre 501 y 800. Por último, 100 (36,63\%), se consideraron negativos ya que el índice serológico fue inferior a 500.

\section{Paratuberculosis.}

Del total de individuos menores de 2 años, 6 animales $(12,76 \%)$ resultaron positivos intensos (++) al presentar un índice superior a 1000, mientras que $8(17,02 \%)$ animales fueron dudosos, con un índice entre 601 y 900. Por último, 33 animales $(70,12 \%)$ resultaron negativos ya que el índice serológico fue inferior a 600. En mayores de dos años la prueba se realizó en 273 animales, de los cuales 26 animales $(9,52 \%)$ resultaron positivos al presentar un índice superior a 900, mientras 64 animales $(23,44 \%)$ se consideraron dudosos con un índice entre 601 y 900. Por último, $183(67,03 \%)$ resultaron negativos ya que el índice serológico fue inferior a 600.

De los 17 animales menores de 2 años positivos a ELISA frente a M. bovis y Map, 3 lo fueron a ambas pruebas.

\section{IV.2. RESULTADOS DE LOS ESTUDIOS post mortem.}

\subsection{Observaciones macroscópicas.}

Se apreciaron lesiones compatibles con la infección tuberculosa en 2 (D12 e I6) de los 343 animales estudiados.

En el animal I6 la lesión pudo observarse solo en ganglios linfáticos mesentéricos y en el animal D12 en ganglios linfáticos del pulmón (mediastínicos). En los dos casos, el aspecto externo del ganglio no se vería alterado sin apreciarse tumefacción evidente. A la sección, se observó un número reducido de nodulillos, del tamaño de la cabeza de un alfiler, con un color blanquecino y con calcificación, que se distribuían fundamentalmente por la zona de la cortical del ganglio. 


\subsection{Lesiones paratuberculosas.}

No se observaron alteraciones macroscópicas evidentes.

\subsubsection{Características microscópicas.}

El examen histológico se llevó a cabo en 62 animales, lo que supone el 18,07\% del total de los animales estudiados. (Tabla IV.4.). Las presencia de lesiones granulomatosas asociadas a infecciones por micobacterias se valoró en: pulmón, ganglios linfáticos de la cabeza (retrofaríngeos, GLC), ganglios linfáticos del pulmón (mediastínicos, GLP) hígado y ganglios linfáticos mesentéricos (GLM).

En un total de 35 animales $(56,45 \%)$ se encontraron lesiones granulomatosas, que fueron clasificadas en varios tipos, tomando como referencia los criterios propuestos por González et al. (2005) para la paratuberculosis bovina o la propuesta por García Castro (2007) para la tuberculosis bovina, que consideran la extensión de la lesión y los tipos celulares presentes.

Siguiendo estos criterios tan solo se observaron lesiones compatibles con las descritas en paratuberculosis y localizadas en nódulos linfáticos, que fueron divididas en 3 grupos principales:

1A) Está lesión estaba caracterizada por la presencia, en la zona interfolicular de los ganglios linfáticos mesentéricos e ileocecales, de pequeños granulomas compuestos por entre 10 y 50 células de morfología macrofágica, con abundante citoplasma claro y presencia de un pigmento marrón-negruzco (ceroide) en menor o mayor medida en el mismo. Entre los macrófagos podían observarse algunos linfocitos (Fig.IV.1.).

1B) Se caracterizaba por presentar entre 5 ó 20 granulomas de diferente tamaño, formados

por un número mayor de células que en 1A, llegando a confluir en algunos casos y ocupando una amplia superficie de la zona interfolicular del nódulo linfático, pero con una distribución multifocal (Fig.IV.1.).

1C) Se observaba la presencia de granulomas similares a los descritos en 1A-1B de mayor tamaño y distribuidos por toda la cortical, llegando llenar todo el espacio interfolicular en algunos casos, presentando una distribución difusa. 

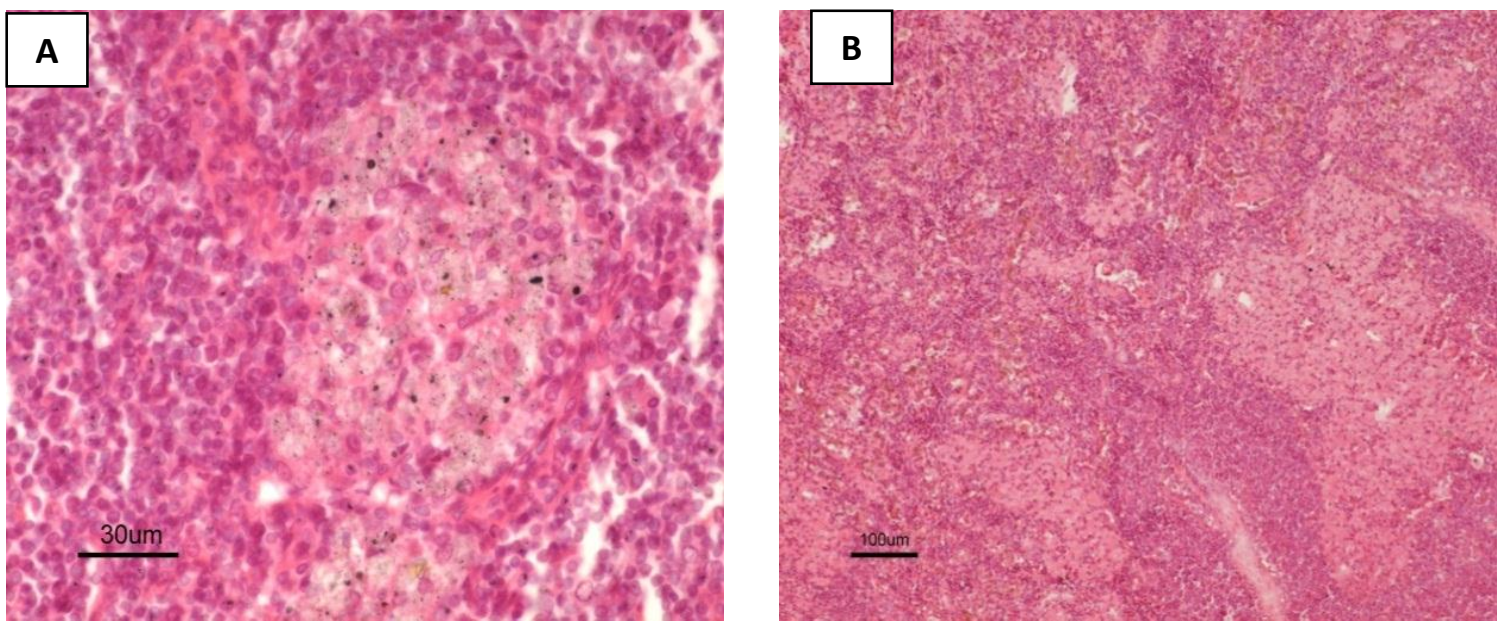

Figura IV.1. Lesiones microscópicas. A: Tipo 1A. Se observa un granuloma bien delimitado, formado por abundantes macrófagos cargados de pigmento ceroide. B: Tipo 1B. La lesión granulomatosa muestra una mayor extensión, ocupando gran parte de la región paracortical.

En un total de 5 animales con lesiones se realizó la tinción de Ziehl-Neelsen: dos de ellos no tenían lesiones; en dos las lesiones ganglionares fueron del tipo $1 \mathrm{C}$ y en uno de tipo 1B, que fueron negativas a la presencia de BAAR en todos los casos.
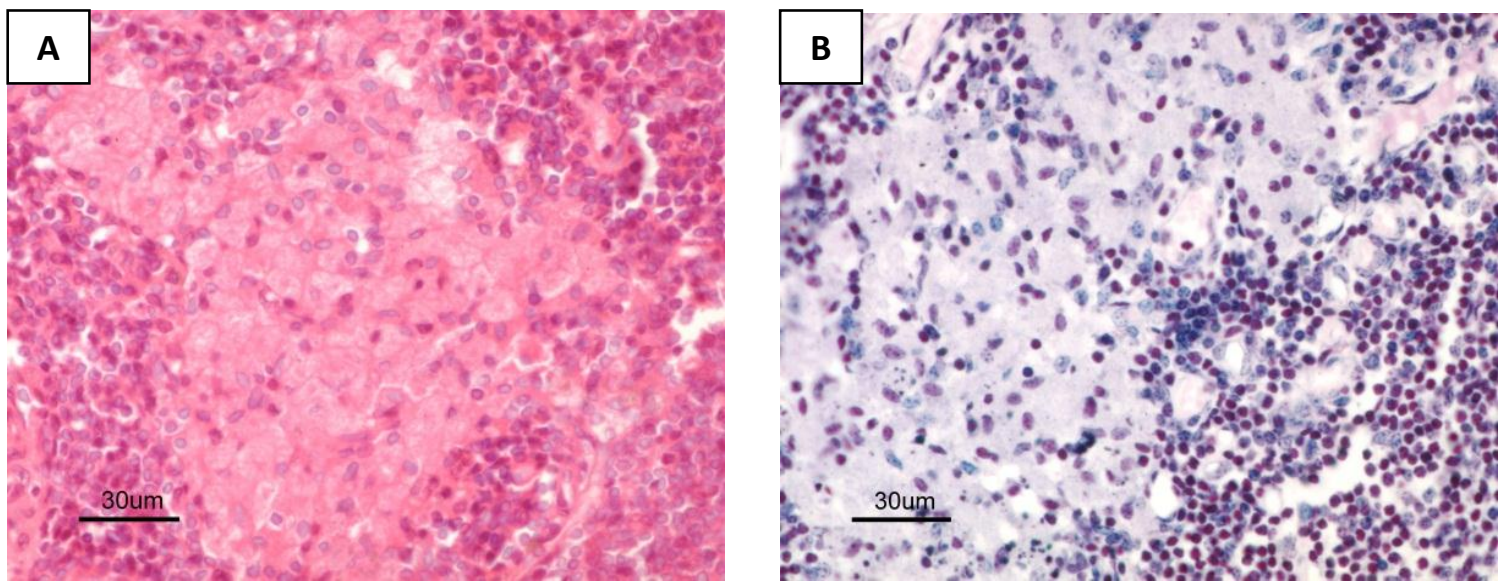

Figura IV.2. Lesión de tipo 1B (A), negativa a la presencia de BAAR mediante la técnica de Ziehl-Neelsen (B).

Además de las descritas, también se observaron piogranulomas en los ganglios linfáticos mesentérico y mediastínico, caracterizados principalmente por la presencia de neutrófilos y macrófagos, rodeados por una cápsula de tejido conjuntivo, que se correspondían con las lesiones observadas macroscópicamente en 2 animales (D12 e I16). 


\begin{tabular}{ccc}
\hline GRUPO (Municipio) & $\begin{array}{c}\mathbf{N}^{\circ} \text { animales/con } \\
\text { lesiones }\end{array}$ & $\%$ \\
\hline A & $3 / 2$ & $66,66 \%$ \\
$\mathbf{B}$ & $3 / 1$ & $50 \%$ \\
$\mathbf{C}$ & $4 / 3$ & $75 \%$ \\
$\mathbf{D}$ & $12 / 6$ & $50 \%$ \\
$\mathbf{E}$ & $1 / 0$ & $0 \%$ \\
$\mathbf{F}$ & $1 / 0$ & $0 \%$ \\
$\mathbf{G}$ & $1 / 0$ & $0 \%$ \\
$\mathbf{H}$ & $1 / 0$ & $0 \%$ \\
$\mathbf{I}$ & $6 / 3$ & $50 \%$ \\
$\mathbf{J}$ & $1 / 1$ & $100 \%$ \\
$\mathbf{K}$ & $1 / 0$ & $0 \%$ \\
$\mathbf{L}$ & $1 / 1$ & $100 \%$ \\
$\mathbf{M}$ & $5 / 2$ & $40 \%$ \\
$\mathbf{N}$ & $9 / 6$ & $66,66 \%$ \\
$\mathbf{O}$ & $2 / 2$ & $100 \%$ \\
$\mathbf{P}$ & $0 / 0$ & $0 \%$ \\
$\mathbf{Q}$ & $5 / 4$ & $80 \%$ \\
$\mathbf{R}$ & $1 / 0$ & $0 \%$ \\
$\mathbf{S}$ & $5 / 4$ & $80 \%$ \\
$\mathbf{T}$ & $0 / 0$ & $0 \%$ \\
\hline
\end{tabular}

Tabla. IV.4. Distribución del número de animales con lesiones según el grupo (municipio).

En un total de $36(58,06 \%)$ animales se encontraron lesiones. En 10 bovinos $(27,77 \%)$ aparecieron lesiones en los GLC. En 4 animales $(11,11 \%)$ en los GLP, en 2 animales $(5,55 \%)$ pudieron observarse lesiones en GLC y GLP, en 2 animales $(5,55 \%)$ en pulmón y GLP. En 12 animales $(33,33 \%)$ las lesiones se observaron en los GLM. En 2 animales $(5,55 \%)$ la lesión se observó en GLC y GLM, en un animal $(2,77 \%)$ en GLP y GLM, y por último en 3 animales $(8,33 \%)$ pudieron observarse lesiones en hígado y ganglios linfáticos mesentéricos. (Tabla IV.5.).

\begin{tabular}{cccccc}
\hline Identif. & Pulmón & GLC & GLP & Hígado & GLM \\
\hline A4 & - & - & - & - & - \\
A5 & - & - & - & - & $+1 \mathrm{~A}$ \\
A10 & - & $+1 \mathrm{~A}$ & - & - & $+1 \mathrm{~A}$ \\
B2 & - & - & - & - & - \\
B5 & - & - & - & - & $+1 \mathrm{~A}$ \\
B7 & - & - & - & - & - \\
C2 & - & - & - & - & $+1 \mathrm{~B}$ \\
C3 & - & - & - & - & - \\
C4 & - & $+1 \mathrm{~A}$ & - & - & - \\
C8 & - & - & - & - & $+1 \mathrm{~A}$ \\
\hline
\end{tabular}




\begin{tabular}{|c|c|c|c|c|c|}
\hline D1 & - & - & - & - & $+1 \mathrm{~A}$ \\
\hline D5 & - & - & $+1 \mathrm{~B}-1 \mathrm{C}$ & - & - \\
\hline D6 & - & - & - & - & - \\
\hline D7 & - & - & - & - & - \\
\hline D9 & - & - & - & - & - \\
\hline D10 & - & - & - & $+1 \mathrm{~A}$ & $+1 \mathrm{~A}$ \\
\hline D11 & - & - & - & - & - \\
\hline D12 & - & - & - & - & - \\
\hline D13 & $+1 \mathrm{~B}-1 \mathrm{C}$ & - & $+1 \mathrm{~B}-1 \mathrm{C}$ & - & - \\
\hline D15 & - & - & - & - & - \\
\hline D20 & - & - & - & - & - \\
\hline D21 & - & $+1 \mathrm{~A}$ & - & - & - \\
\hline E3 & - & - & - & - & - \\
\hline F4 & - & - & - & - & - \\
\hline G3 & - & - & - & - & - \\
\hline H10 & - & - & - & - & - \\
\hline I3 & - & $+1 \mathrm{~B}$ & $+1 \mathrm{~B}$ & - & - \\
\hline I6 & - & - & - & $+1 \mathrm{~A}$ & $+1 \mathrm{~A}$ \\
\hline I7 & - & - & - & - & - \\
\hline I8 & - & - & - & - & - \\
\hline I9 & - & - & - & - & - \\
\hline I12 & - & $+1 \mathrm{~B}$ & - & - & - \\
\hline J4 & - & $+1 \mathrm{~A}$ & $+1 \mathrm{~B}$ & - & - \\
\hline K5 & - & - & - & - & - \\
\hline L2 & - & - & $+1 \mathrm{~A}$ & - & $+1 \mathrm{~A}$ \\
\hline M1 & - & $+1 \mathrm{~B}$ & - & - & - \\
\hline M2 & - & - & - & - & $+1 \mathrm{~B}$ \\
\hline M3 & - & - & - & $+1 \mathrm{C}$ & $+1 \mathrm{C}$ \\
\hline M8 & - & - & - & - & - \\
\hline M9 & - & - & - & - & - \\
\hline N3 & - & - & - & - & - \\
\hline N5 & - & $+1 \mathrm{~A}$ & - & - & - \\
\hline N8 & - & - & - & - & - \\
\hline N12 & - & - & - & - & $+1 \mathrm{~A}$ \\
\hline N15 & - & $+1 \mathrm{~A}$ & - & - & - \\
\hline N18 & - & - & - & - & - \\
\hline N20 & - & - & - & - & $+1 \mathrm{C}$ \\
\hline N22 & - & $+1 \mathrm{~A}-1 \mathrm{~B}$ & - & - & - \\
\hline N24 & - & - & - & - & $+1 \mathrm{C}$ \\
\hline O4 & - & - & - & - & $+1 \mathrm{~A}$ \\
\hline O6 & - & $+1 \mathrm{C}$ & - & - & - \\
\hline Q2 & - & - & $+1 \mathrm{~B}$ & - & - \\
\hline Q4 & - & - & - & - & $+1 \mathrm{C}$ \\
\hline Q5 & - & $+1 \mathrm{~B}$ & - & - & - \\
\hline Q11 & - & $+1 \mathrm{C}$ & - & - & - \\
\hline Q14 & - & - & - & - & - \\
\hline
\end{tabular}




\begin{tabular}{cccccc}
\hline R7 & - & - & - & - & - \\
S14 & - & - & $+1 \mathrm{~B}$ & - & - \\
S16 & - & - & - & - & - \\
S18 & $+1 \mathrm{~A}$ & - & $+1 \mathrm{~A}$ & - & - \\
S39 & - & - & - & - & $+1 \mathrm{C}$ \\
S46 & - & - & $+1 \mathrm{~B}$ & - & - \\
\hline
\end{tabular}

Tabla IV.5. Identificación de los animales en los que se valoraron las lesiones histológicas. -: sin lesión; +: con lesión. GLC: ganglios linfáticos de la cabeza; GLP: ganglios linfáticos del pulmón; GLM: ganglios linfáticos mesentéricos.

\begin{tabular}{lcccc}
\hline Localización Anatómica & $\mathbf{1 A}$ & $\mathbf{1 B}$ & $\mathbf{1 C}$ & Total con lesión/examinados\% \\
\hline $\begin{array}{l}\text { Ganglios linfáticos de la } \\
\text { cabeza }\end{array}$ & 7 & 5 & 2 & $14 / 37(37,83 \%)$ \\
$\begin{array}{l}\text { Ganglios linfáticos del } \\
\text { pulmón }\end{array}$ & 2 & 7 & 2 & $11 / 28(39,28 \%)$ \\
$\begin{array}{l}\text { Ganglios linfáticos } \\
\text { mesentéricos }\end{array}$ & 10 & 2 & 5 & $17 / 35(48,57 \%)$ \\
$\begin{array}{l}\text { Pulmón } \\
\text { Hígado }\end{array}$ & 1 & 1 & 1 & $3 / 26(11,53 \%)$ \\
Total & 0 & 0 & 1 & $1 / 33(3,03 \%)$ \\
\hline
\end{tabular}

Tabla.IV.6. Número de lesiones según la distribución anatómica y su tipo.

\section{IV.3. RESULTADOS EN LA PRUEBA DE DETECCIÓN DE MICOBACTERIAS MEDIANTE LA PCR.}

La técnica PCR se realizó en un "pool" que contenía muestras de ganglio linfático retrofaríngeo, ganglio linfático mediastínico, pulmón, hígado y ganglio linfático mesentérico, frente a M. bovis y Map. Utilizando el kit comercial Speedtools Tissue DNA se realizó el PCR frente a Maa en muestras individuales de animales seleccionados con lesiones histopatológicas (tipo 1A, 1B y 1C) a partir de tejido incluido en parafina.

De los 275 animales examinados, 20 resultaron positivos $(7,28 \%)$ para tuberculosis (M. bovis), mientras que 11 animales resultaron positivos (4\%) a paratuberculosis (Map), al aparecer la banda característica en el gel de agarosa en dichas enfermedades (Tabla IV.7.). 


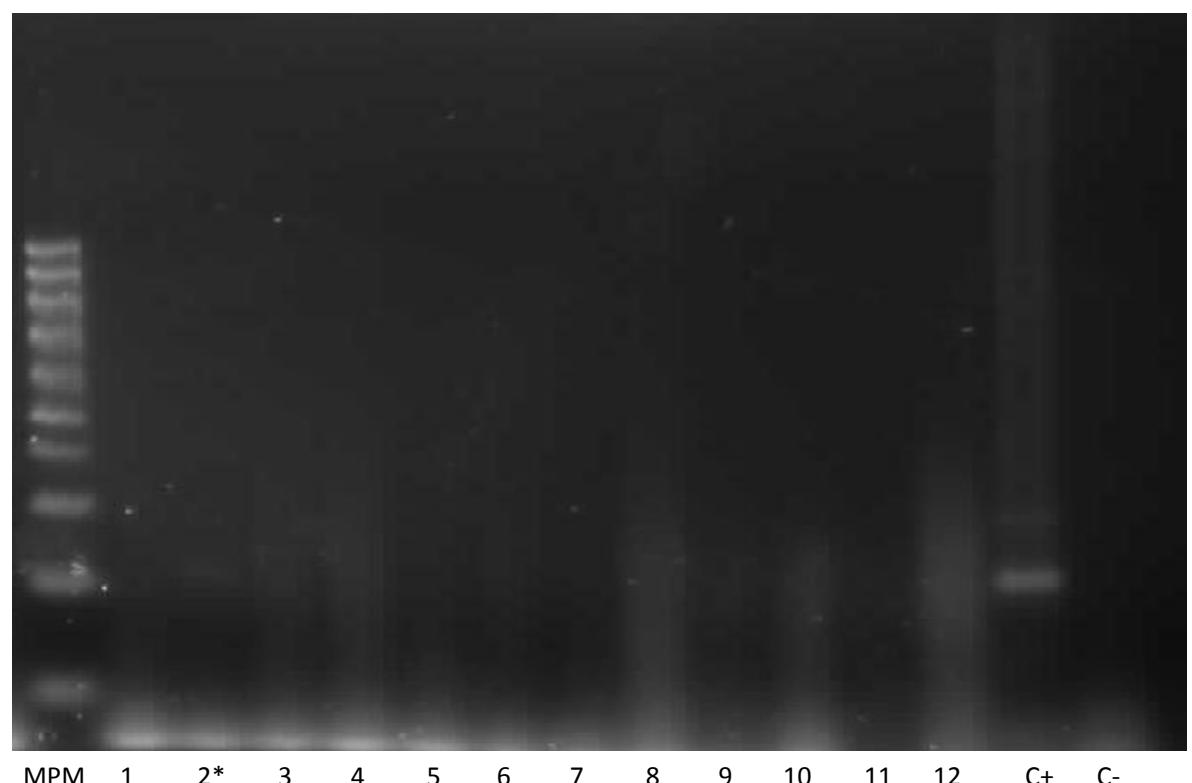

C+: Control positivo.

C-: Control negativo.

Muestra positiva: $2^{*}$

Muestras negativas: $1,3,4,5,6,7,8,9$, 10,11 y 12 .

MPM: Marcador de peso molecular.

Figura IV.3. Revelado de la PCR en gel de agarosa con muestras positivas a la secuencia de inserción IS6110 de M. bovis.

\begin{tabular}{cccc}
\hline $\begin{array}{c}\text { GRUPO } \\
\text { (Municipio) }\end{array}$ & $\mathbf{N}^{\circ}$ Animales & M. bovis + & Map + \\
\hline A & 13 & 0 & $1(7,69 \%)$ \\
B & 11 & 0 & 0 \\
C & 6 & 0 & 0 \\
D & 12 & $1(8,33 \%)$ & $1(8,33 \%)$ \\
E & 12 & $3(25 \%)$ & $1(8,33 \%)$ \\
F & 8 & 0 & 0 \\
G & 14 & 0 & 0 \\
H & 12 & $1(8,33 \%)$ & $1(8,33 \%)$ \\
I & 16 & $2(12,5 \%)$ & $1(6,25 \%)$ \\
J & 16 & $3(18,75 \%)$ & $1(6,25 \%)$ \\
K & 11 & $1(9,09 \%)$ & $1(9,09 \%)$ \\
L & 8 & 0 & 0 \\
M & 14 & $2(14,28 \%)$ & 0 \\
N & 22 & $2(9,09 \%)$ & $1(11,11 \%)$ \\
O & 9 & $2(22,22 \%)$ & 0 \\
P & 17 & 0 & $1(3,70 \%)$ \\
Q & 27 & $1(3,70 \%)$ & 0 \\
R & 13 & $1(7,69 \%)$ & $1(3,70 \%)$ \\
S & 27 & $1(3,70 \%)$ & $1(14,28 \%)$ \\
T & 7 & 0 & $11(4 \%)$ \\
\hline TOTA & 275 & $20(7,27 \%)$ & \\
\hline IV & & $120 \%)$ & \\
\hline
\end{tabular}

Tabla IV.7. Resultados de la PCR frente a M. bovis y Map realizada sobre 275 animales. 
Los reaccionantes positivos a tuberculosis se distribuían en 12 grupos (municipio): D (8,33\%), E (25\%), H (8,33\%), I (12,5\%), J (18,75\%), K (9,09\%), M (14,28\%), N $(9,09 \%)$, O $(22,22 \%)$, Q $(3,70 \%), \mathrm{R}(7,69 \%)$ y S $(3,70 \%)$. El porcentaje de positividad global fue del $11,89 \%$. Frente a paratuberculosis los reaccionantes positivos se distribuían en 11 grupos: A $(7,69 \%), \mathrm{D}(8,33 \%), \mathrm{E}(8,33 \%), \mathrm{H}(8,33 \%), \mathrm{I}(6,25 \%), \mathrm{J}(6,25 \%), \mathrm{K}$ $(9,09 \%), \mathrm{O}(11,11 \%), \mathrm{Q}(3,70 \%), \mathrm{S}(3,70 \%)$ y $\mathrm{T}(14,28 \%)$. El porcentaje de positividad global fue del $7,91 \%$.

De acuerdo a la edad los animales se dividieron en dos grupos, como ya se mencionó en el capítulo de materiales y métodos: animales menores de 2 años y animales mayores de 2 años. La técnica de la PCR, se realizó en 47 animales menores de dos años y en 228 animales mayores de dos años.

La PCR frente a M. bovis en animales menores de dos fue positiva en 3 de ellos $(6,38 \%) \mathrm{y}$, en los mayores de dos años, 17 (7,45\%) animales fueron positivos. La PCR frente a Map en animales menores de dos años, sólo fue positiva en uno $(2,12 \%)$ y en animales mayores de dos años, 10 (4,38\%) animales fueron positivos (Gráfico IV.3.). Estas diferencias no fueron estadísticamente significativas.

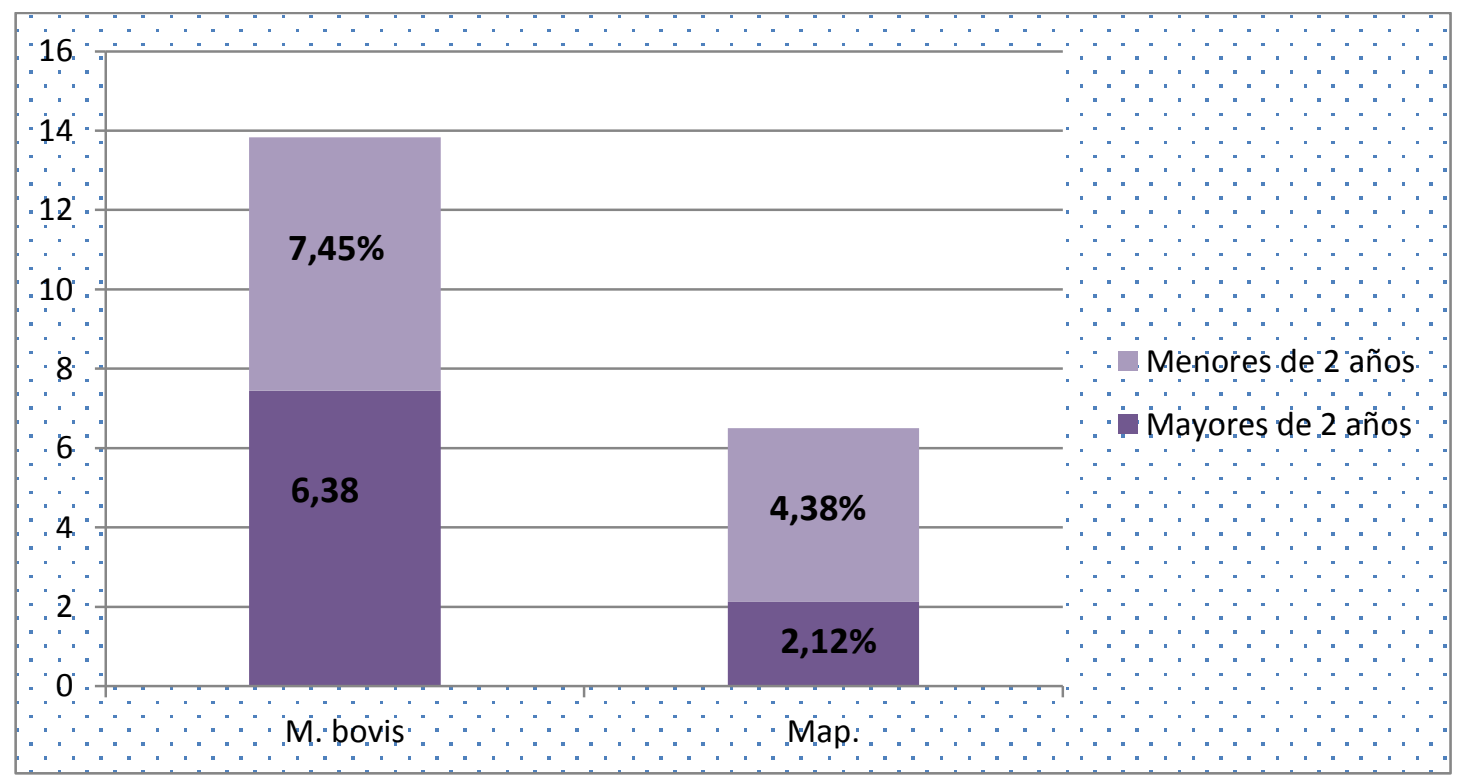

Gráfico.IV.3. Porcentaje de acuerdo a la edad en la PCR frente a M. bovis y Map.

La PCR frente a Maa se realizó en 14 animales con lesiones a partir de muestras de ganglios linfáticos mesentéricos $(n=6)$, retrofaríngeos $(n=6)$ y mediastínicos $(n=3)$. De los 14 animales examinados, $13(93,33 \%)$ resultaron positivos a Maa al aparecer la banda característica en el gel de agarosa (Tabla IV.8.). De ellos, dos (S18, D12) también lo fueron a $M$. bovis, mientras que todos fueron negativos a Map. 


\begin{tabular}{|c|c|c|c|}
\hline $\begin{array}{l}\text { Identif. Animal/ } \\
\text { Localización }\end{array}$ & M. bovis & Map & Maa \\
\hline M1 (GLC) & NEG. & NEG. & POS. \\
\hline I3 (GLC) & NEG. & NEG. & NEG. \\
\hline S18 (GLP) & POS & NEG. & POS. \\
\hline D5 (GLP) & NEG. & NEG. & POS. \\
\hline M3 (GLM) & NEG. & NEG. & POS. \\
\hline D11 (GLP) & NEG. & NEG. & POS. \\
\hline D12 (GLP) & NEG. & NEG. & POS. \\
\hline D12 (GLC) & POS. & NEG. & POS. \\
\hline D13 (GLP) & NEG. & NEG. & POS. \\
\hline C2 (GLM) & NEG. & NEG. & POS. \\
\hline N12 (GLP) & NEG. & NEG. & POS. \\
\hline C4 (GLC) & NEG. & NEG. & POS. \\
\hline S39 (GLM) & NEG. & NEG. & POS. \\
\hline N20 (GLM) & NEG. & NEG. & POS. \\
\hline O6 (GLC) & NEG. & NEG. & POS. \\
\hline C8 (GLM) & NEG. & NEG. & POS. \\
\hline
\end{tabular}

Tabla.IV.8. Resultados de la PCR realizada sobre 14 animales en los que se analizaron las tres micobacterias (M. bovis, Map: M. avium subsp paratuberculosis; Maa: M. avium subsp avium).

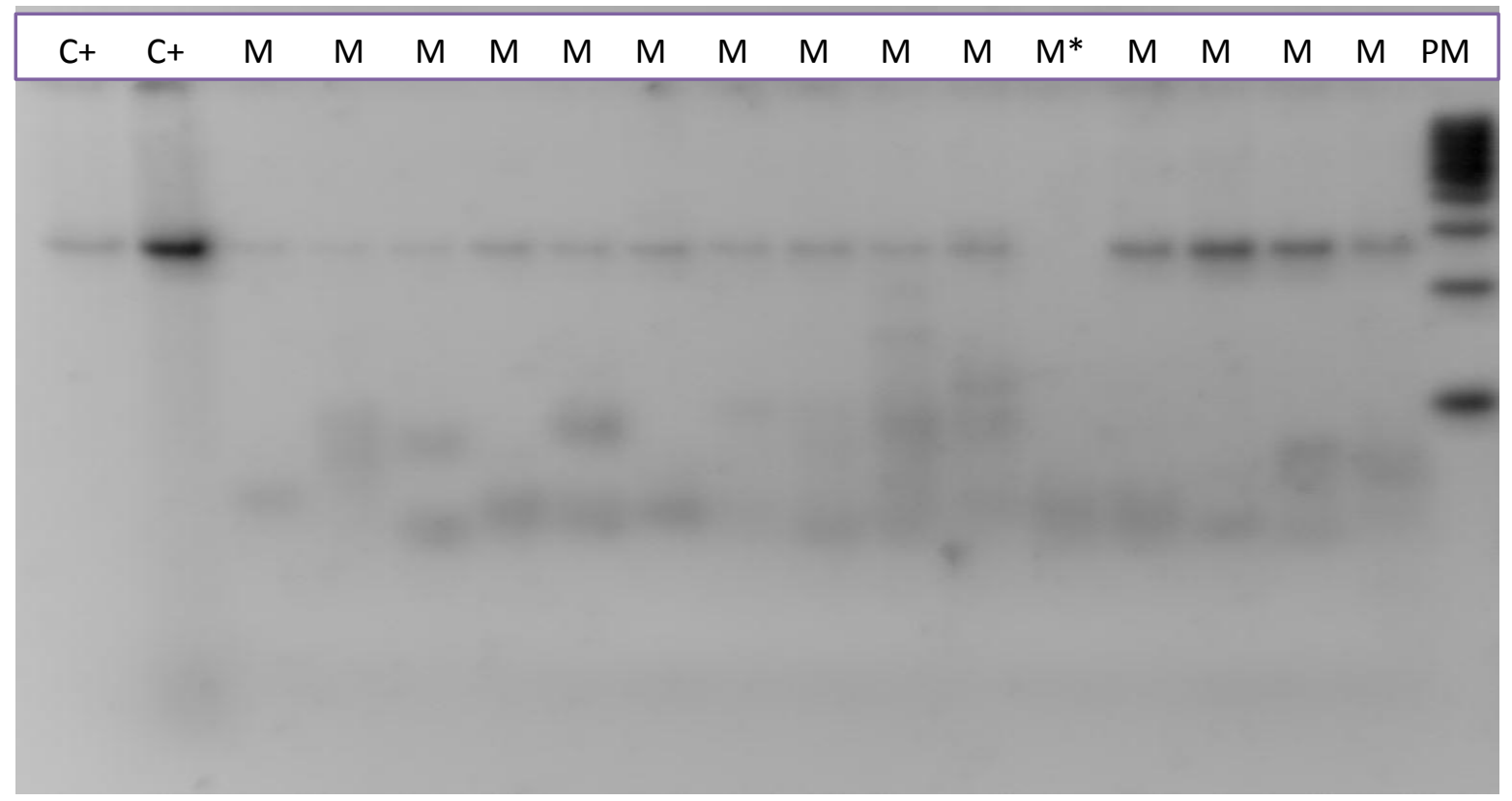

Figura.IV.4. Revelado de la PCR en gel de agarosa. Muestras positivas a la secuencia de inserción IS901 de Maa $\mathrm{C}+$ : control positivo. M: muestra positiva. $\mathrm{M}^{*}$ : muestra negativa. PM: peso molecular. 


\section{4. COMPARACIÓN ENTRE TÉCNICAS DIAGNÓSTICAS.}

\subsection{Comparación entre el diagnóstico histopatológico y el diagnóstico inmunológico.}

\subsubsection{Comparación entre el diagnóstico histopatológico y la IDR.}

Ambas técnicas se llevaron a cabo en 58 animales de los cuales $7(12,06 \%)$ resultaron positivos a la prueba de IDR. De ellos, 2 presentaron lesiones en los ganglios linfáticos de la cabeza y el resto no presentó lesiones microscópicas (Tabla IV.9.).

De los 51 animales con resultado negativo a la prueba de IDR, en 21 no se observaron lesiones, mientras que en los 30 restantes con lesiones, 10 animales presentaban lesiones sólo en los ganglios linfáticos de la cabeza, 12 animales en ganglios linfáticos mesentéricos y en 4 animales en ganglios linfáticos mediastínicos. Por último, en 3 animales en hígado y ganglios linfáticos mesentéricos, en dos animales en pulmón y ganglios linfáticos mediastínicos, en dos animales en ganglios linfáticos de la cabeza y mediastínicos, en un animal en ganglios linfáticos de la cabeza y ganglios linfáticos mediastínicos y en un animal en ganglios linfáticos mediastínicos y mesentéricos.

\begin{tabular}{lccc}
\hline & \multicolumn{2}{c}{ HISTOPALOGÍA } & TOTAL \\
& Positivos & Negativos & \\
\hline IDR + & 2 & 5 & 7 \\
IDR - & 30 & 21 & 51 \\
TOTAL & $\mathbf{3 2}$ & $\mathbf{2 6}$ & $\mathbf{5 8}$ \\
\hline
\end{tabular}

Tabla. IV.9. Relación del número de animales con lesiones y la respuesta a la intradermorreacción (IDR) con PPD bovina.

El índice kappa fue 0,119 , lo que indica una concordancia débil entre las dos técnicas diagnósticas.

\subsubsection{Comparación entre el diagnóstico histopatológico y el ELISA.}

\section{Tuberculosis.}

Ambas pruebas se realizaron en 62 animales, de los cuales $17(27,41 \%)$ fueron positivos a la prueba ELISA, 6 animales no presentaron lesiones, en 5 animales pudimos observar lesiones en los ganglios linfáticos de la cabeza, en 4 animales en ganglios linfáticos mesentéricos, en uno en ganglios linfáticos mediastínicos y por último, sólo en un animal pudimos observar lesiones en los ganglios linfáticos de la cabeza y mesentéricos. De los 25 (40,32\%) animales dudosos (índice se entre 601 y 800), en 11 animales no se 
encontraron lesiones, mientras que en 3 animales se observaron lesiones en ganglios linfáticos de la cabeza, en 3 animales en ganglios linfáticos mesentéricos y en dos animales en ganglios linfáticos mediastínicos. Además, pudimos observar lesiones múltiples en un mismo animal, en dos se observaron lesiones en ganglios linfáticos de la cabeza y ganglios linfáticos mediastínicos, en dos animales en pulmón y ganglios linfáticos mediastínicos y en 2 animales en hígado y ganglios linfáticos mesentéricos (Tabla IV.10.).

\section{HISTOPATOLOGÍA TOTAL}

\begin{tabular}{lccc} 
& + & - & \\
\hline ELISA + & 11 & 6 & 25 \\
ELISA +/- & 14 & 11 & 20 \\
ELISA - & 10 & 10 & 62 \\
\hline TOTAL & 35 & 27 & \\
\hline
\end{tabular}

Tabla. IV.10. Relación entre los resultados del test ELISA frente a M. bovis.

Tomando los animales con resultado dudoso en el grupo de los negativos, el ELISA presentó un índice kappa de 0,037, lo que indica una concordancia débil entre las dos técnicas diagnósticas. Cuando los animales con resultado dudoso en el ELISA se consideraron positivos, el índice kappa fue 0,046, siendo igualmente una concordancia débil.

\section{Paratuberculosis.}

De los $11(17,74 \%)$ animales positivos a la prueba ELISA, 6 animales presentaron lesiones, 3 de ellos en los ganglios linfáticos de la cabeza y 3 animales en los ganglios linfáticos mesentéricos. En 16 animales el índice se situó entre 6001 y 900, y por lo tanto se consideraron dudosos; de estos, en 4 no se encontraron lesiones, mientras que en 4 animales se observaron lesiones en los ganglios linfáticos mesentéricos, en 3 animales lesiones en ganglios linfáticos de la cabeza, en 2 animales en ganglios linfáticos mediastínicos, en 2 animales la lesión se observó en hígado y ganglios linfáticos mesentéricos, en un animal en ganglios linfáticos mediastínicos y mesentéricos (Tabla IV.11.).

\begin{tabular}{lccc}
\hline & HISTOPATOLOGÍA & TOTAL & \\
& + & - & \\
\hline ELISA + & 6 & 5 & 11 \\
ELISA +/- & 12 & 4 & 16 \\
ELISA - & 17 & 18 & 35 \\
TOTAL & 35 & 27 & 62 \\
\hline
\end{tabular}

Tabla IV.11. Relación entre los resultados del test ELISA frente a Map. 
Tomando los animales con resultado dudoso en el grupo de los negativos, el ELISA presentó un índice kappa de -0,005, lo que indica una falta de concordancia entre las dos técnicas diagnósticas. Cuando los animales con resultado dudoso en el ELISA se consideraron positivos, el índice kappa fue 0,080, lo que supone una concordancia débil.

\subsubsection{Comparación entre el diagnóstico histopatológico y la PCR.}

\section{PCR frente a M. bovis.}

Ambas técnicas se llevaron a cabo en 39 animales, de los que 9 (23,07\%) resultaron positivos a la PCR. De estos, 3 animales presentaron lesiones en los ganglios linfáticos de la cabeza, un animal presentó lesiones en los ganglios linfáticos del pulmón y en un animal la lesión pudo observarse en el hígado y ganglios linfáticos mesentéricos, mientras que los 4 restantes no presentaron lesiones. Entre los 30 animales negativos a la técnica PCR, 14 no presentaron lesiones histológicas. En los 16 animales restantes con lesiones, en 8 animales se encontraron afectados los ganglios linfáticos mesentéricos, en 5 animales los ganglios linfáticos de la cabeza, en un animal en ganglios linfáticos de la cabeza y mediastínicos, en un animal en ganglios linfáticos de la cabeza y mesentéricos y en un animal en ganglios linfáticos mediastínicos y mesentéricos (Tabla IV.12.). El índice de kappa fue 0,009, lo que indica una concordancia débil.

HISTOPATOLOGÍA TOTAL

\begin{tabular}{llll} 
& + & - & \\
\hline PCR + & 5 & 4 & 30 \\
PCR - & 16 & 14 & 39 \\
TOTAL & 21 & 18 & \\
\hline
\end{tabular}

Tabla. IV.12. Relación entre los resultados de la PCR frente a M. bovis y presencia de lesiones, expresado como número de animales.

\section{PCR frente a Map.}

Ambas técnicas se llevaron a cabo en 39 animales, de ellos dos $(5,12 \%)$ resultaron positivos a la PCR, y sólo un animal presentó lesiones, en ganglios linfáticos de la cabeza. De los 37 animales negativos a la técnica PCR 17 no presentaron lesiones histológicas. De los 20 animales con lesiones, en 9 animales se observaron lesiones en ganglios linfáticos mesentéricos, en 7 animales en ganglios linfáticos de la cabeza, en un animal en ganglios linfáticos del pulmón, en un animal en ganglios linfáticos de la cabeza y del pulmón, en un animal en ganglios linfáticos de la cabeza y mesentéricos y en un animal en ganglios 
linfáticos del pulmón y mesentéricos. (Tabla IV.13.). El índice kappa fue de -0,006, lo que supone una falta de concordancia entre las dos técnicas diagnósticas.

\begin{tabular}{cccc}
\hline & \multicolumn{2}{c}{ HISTOPATOLOGÍA } & TOTAL \\
\hline PCR + & + & - & \\
\hline PCR - & 1 & 1 & 2 \\
TOTAL & 20 & 17 & 37 \\
\hline
\end{tabular}

Tabla. IV.13. Relación entre los resultados de la PCR frente a Map.

\section{PCR frente a Maa.}

Esta técnica se llevó a cabo en 14 animales seleccionados con lesiones histopatológicas, de ellos $13(93,33 \%)$ resultaron positivos a la PCR, 4 (30,76\%) animales presentaron lesiones en ganglios linfáticos de la cabeza, 3 (23,07\%) animales en ganglios linfáticos del pulmón y $6(46,15 \%)$ animales en ganglios linfáticos mesentéricos. El animal que resulto negativo a la técnica PCR presento lesiones histológicas en ganglios linfáticos de la cabeza y del pulmón (Tabla.IV.14.).

\begin{tabular}{lccc}
\hline & HISTOPATOLOGÍA & TOTAL & \\
\hline PCR + & + & - & 13 \\
PCR - & 13 & 0 & 1 \\
TOTAL & 1 & 0 & 14 \\
\hline
\end{tabular}

Tabla. IV.14. Relación entre los resultados de la PCR frente a Maa.

\subsubsection{Relación entre la respuesta a la intradermorreacción (IDR) y el ELISA.}

\section{Tuberculosis.}

Ambas técnicas se llevaron a cabo en 273 animales de los cuales $25(9,15 \%)$ resultaron positivos a la IDR. De estos animales 8 (32\%) fueron positivos a la prueba ELISA, 10 (40\%) fueron dudosos y 7 animales (28\%) negativos. De los 248 animales negativos a la IDR, 38 animales $(15,32 \%)$ resultaron positivos a la prueba ELISA, 120 animales (48,38\%) fueron dudosos al presentar un índice entre 601 y 800 y, 90 animales $(36,29 \%)$ resultaron negativos a ambas pruebas (Tabla IV.15.). 


\section{ELISA}

\begin{tabular}{lccccc} 
& Positivos + & Dudosos $+/-$ & Negativos - (Dudosos/Negativos) & TOTAL \\
\hline IDR + & 8 & 10 & 7 & 17 & $\mathbf{2 5}$ \\
IDR - & 38 & 120 & 90 & 210 & $\mathbf{2 4 8}$ \\
TOTAL & $\mathbf{4 6}$ & $\mathbf{9 7}$ & $\mathbf{1 3 0}$ & $\mathbf{2 2 7}$ & $\mathbf{2 7 3}$ \\
\hline
\end{tabular}

Tabla. IV.15. Número de animales IDR positivos y negativos al test ELISA frente a M. bovis.

Tomando a los animales tanto con resultado dudoso como negativos a la prueba ELISA, se observó un índice de kappa del 0,121, lo que indica una concordancia débil. Mientras que considerando conjuntamente a los animales con resultado dudoso y positivo el índice kappa fue 0,022, con una concordancia igualmente débil.

\section{Paratuberculosis.}

La prueba se realizó en 273 animales de los cuales $25(9,15 \%)$ resultaron positivos a la IDR. De estos mismos animales, 10 (40\%) animales fueron positivos a la prueba ELISA, $7(28 \%)$ resultaron dudosos y $8(32 \%)$ animales fueron negativos a dicha prueba. El resto de los animales $(n=248)$ fue negativo a la IDR, de los que 16 animales $(6,45 \%)$ resultaron positivos a la prueba ELISA, 56 animales $(22,58 \%)$ fueron dudosos al presentar un índice entre 601 y 800 y, 176 animales $(70,96 \%$ ) resultaron negativos a ambas pruebas (Tabla IV.16.).

\begin{tabular}{lccccc}
\hline & & \multicolumn{3}{c}{ ELISA } \\
& Positivos + & Dudosos $+/-$ & Negativos - & (Dudosos/Negativos) & TOTAL \\
\hline IDR + & 10 & 7 & 8 & 15 & $\mathbf{2 5}$ \\
IDR - & 16 & 56 & 176 & 323 & $\mathbf{2 4 8}$ \\
TOTAL & $\mathbf{2 6}$ & $\mathbf{6 3}$ & $\mathbf{1 8 4}$ & $\mathbf{3 4 3}$ & $\mathbf{2 7 3}$ \\
\hline
\end{tabular}

Tabla. IV.16. Número de animales IDR positivos y negativos al test ELISA frente a Map.

Tomando a los animales tanto con resultado dudoso como negativos a la prueba ELISA, el índice de kappa fue del 0,330, lo que indica una concordancia escasa. Considerando a los animales con resultado dudoso y positivo el índice kappa fue 0,181 , siendo una concordancia débil. 


\subsubsection{Relación entre la PCR y la IDR.}

\section{Tuberculosis.}

Ambas técnicas se llevaron a cabo en 228 animales de los cuales 17 animales $(7,45 \%)$ resultaron positivos a la PCR frente a $M$. bovis, 21 animales $(5,70 \%)$ resultaron positivos a la IDR y, 8 animales resultaron positivos para ambas técnicas, mientras que en 198 animales el resultado fue negativo para ambas técnicas (Tabla IV.17.).

\begin{tabular}{lccc}
\hline & \multicolumn{2}{c}{ PCR } & \\
& Positivos & Negativos & TOTAL \\
\hline IDR + & 8 & 13 & 21 \\
IDR - & 9 & 198 & 207 \\
TOTAL & $\mathbf{1 7}$ & $\mathbf{2 1 1}$ & $\mathbf{2 2 8}$ \\
\hline
\end{tabular}

Tabla IV.17. Número de animales PCR positivos y negativos frente a M. bovis y a la IDR simple bovina.

Tomando la PCR como referencia, la IDR presentó un valor de sensibilidad y especificidad del 47,05\% y del 93,83\% respectivamente, siendo el índice kappa 0,369, lo que indica una concordancia escasa.

\section{Paratuberculosis.}

Ambas técnicas se llevaron a cabo en 228 animales de los cuales 11 animales $(4,82 \%)$ resultaron positivos a la PCR frente a Map, 21 animales (5,70\%) resultaron positivos a la IDR, 3 animales resultaron positivos para ambas técnicas, mientras que en 199 animales el resultado fue negativo tanto para PCR como para IDR (Tabla IV.18.).

\begin{tabular}{lccc}
\hline & \multicolumn{2}{c}{ PCR } & \\
& Positivos & Negativos & TOTAL \\
\hline IDR + & 3 & 18 & 21 \\
IDR - & 8 & 199 & 207 \\
TOTAL & $\mathbf{1 1}$ & $\mathbf{2 1 7}$ & $\mathbf{2 2 8}$ \\
\hline
\end{tabular}

Tabla IV.18. Número de animales PCR positivos y negativos frente a Map y a la IDR simple bovina.

Tomando la PCR como referencia, la IDR presentó un valor de sensibilidad y especificidad del $27,27 \%$ y del $91,70 \%$ respectivamente, siendo el índice kappa 0,133, lo que indica una concordancia débil. 


\subsubsection{Relación entre la PCR y el ELISA}

\subsubsection{Relación entre la PCR tb y el ELISA frente a M. bovis.}

Ambas técnicas se llevaron a cabo en 252 animales y, $18(7,17 \%)$ resultaron positivos a la PCR. De ellos, 13 animales $(72,22 \%)$ fueron positivos a la prueba ELISA, 2 $(11,11 \%)$ animales resultaron dudosos y $3(16,67 \%)$ animales fueron negativos. De los 234 animales PCR negativos, 41 (16,33\%) resultaron positivos la prueba ELISA, $119(50,85 \%)$ fueron dudosos al presentar un índice entre 601 y 800, mientras que 74 (29,48\%) resultaron negativos a ambas pruebas (Tabla IV.19.).

Tomando como referencia la PCR, e incluyendo los animales con resultado dudoso en el grupo de los negativos, la prueba ELISA presentó una sensibilidad del $24,07 \%$ y una especificidad del 97,47\%. El índice kappa fue de 0,284, lo que indica una concordancia débil entre las dos técnicas diagnósticas. Cuando los animales con resultado dudoso en el ELISA se consideraron positivos, la sensibilidad y especificidad fueron del $11,53 \%$ y del 97,54\% respectivamente, mientras que el índice kappa fue de 0,088, lo que supone una concordancia débil.

\begin{tabular}{lccccc}
\hline & \multicolumn{2}{c}{ ELISA M. bovis } & \\
& Positivos + & Dudosos & Negativos - & (Dudosos/Negativos) & TOTAL \\
\hline PCR + & 13 & 2 & 3 & 5 & $\mathbf{1 8}$ \\
PCR - & 41 & 74 & 119 & 193 & $\mathbf{2 3 4}$ \\
TOTAL & $\mathbf{5 4}$ & $\mathbf{7 6}$ & $\mathbf{1 2 2}$ & $\mathbf{1 9 8}$ & $\mathbf{2 5 2}$ \\
\hline
\end{tabular}

Tabla IV.19. Número y porcentaje de animales PCR (frente a M. bovis) positivos y negativos al test ELISA frente a M. bovis.

\subsubsection{Relación entre la PCR tb y el ELISA frente a Map.}

Ambas técnicas se llevaron a cabo en 252 animales, $18(7,17 \%)$ resultaron positivos a la PCR, de los cuales 8 animales $(44,46 \%)$ fueron positivos a la prueba ELISA, 5 $(27,77 \%)$ animales resultaron dudosos y $5(27,77 \%)$ animales fueron negativos. De los 234 animales PCR negativos, $23(9,82 \%)$ resultaron positivos a la prueba ELISA con un índice superior a 900, $55(23,50 \%)$ fueron dudosos al presentar un índice entre 601 y 900, mientras que $156(66,66 \%)$ resultaron negativos a ambas pruebas (Tabla IV.20.).

El índice kappa fue de 0,260, lo que indica una concordancia escasa entre las dos técnicas diagnósticas. Cuando los animales con resultado dudoso se consideraron como positivos el índice kappa fue 0,135 (concordancia débil). 


\section{ELISA}

\begin{tabular}{lccccc} 
& \multicolumn{1}{c}{ Positivos + Dudosos $+/$} & Negativos - & (Dudosos/Negativos) & TOTAL \\
\hline PCR + & 8 & 5 & 5 & 10 & $\mathbf{1 8}$ \\
PCR - & 23 & 55 & 156 & 211 & $\mathbf{2 3 4}$ \\
TOTAL & $\mathbf{3 1}$ & $\mathbf{6 0}$ & $\mathbf{1 6 1}$ & $\mathbf{2 2 1}$ & $\mathbf{2 5 2}$ \\
\hline
\end{tabular}

Tabla IV.20. Número y porcentaje de animales PCR (frente a M. bovis) positivos y negativos al test ELISA frente a Map.

\subsubsection{Relación entre la PCR ptb y el ELISA frente a M. bovis.}

Ambas técnicas se llevaron a cabo en 252 animales, $8(3,17 \%)$ resultaron positivos a la PCR, de los cuales 6 animales (75\%) fueron positivos a la prueba ELISA, un (25\%) animal resultó dudoso y un animal (25\%) negativo. De los 244 animales PCR negativos, 48 $(19,67 \%)$ resultaron positivos a la prueba ELISA con un índice superior a 900, 120 $(49,18 \%)$ fueron dudosos al presentar un índice entre 601 y 900, mientras que $76(31,14 \%)$ resultaron negativos a ambas pruebas (Tabla IV.21.).

El índice kappa fue de 0,146, lo que indica una concordancia débil entre las dos técnicas diagnósticas. Cuando los animales con resultado dudoso se consideraron como positivos, el índice kappa fue de 0,017, indicando una concordancia también débil.

\begin{tabular}{lccccc}
\hline & \multicolumn{2}{c}{ ELISA } & \\
& Positivos+ & Dudosos $+/$ & Negativos- & (Dudosos/Negativos) & TOTAL \\
\hline PCR + & 6 & 1 & 1 & 2 & $\mathbf{8}$ \\
PCR - & 48 & 120 & 76 & 196 & $\mathbf{2 3 4}$ \\
TOTAL & $\mathbf{5 4}$ & $\mathbf{1 2 1}$ & $\mathbf{7 7}$ & $\mathbf{1 9 8}$ & $\mathbf{2 5 2}$ \\
\hline
\end{tabular}

Tabla IV.21. Número y porcentaje de animales PCR (frente a Map) positivos y negativos al test ELISA frente a M. bovis.

\subsubsection{Relación entre la PCR ptb y el ELISA frente a Map.}

Ambas técnicas se llevaron a cabo en 252 animales, $8(3,17 \%)$ resultaron positivos a la PCR, de los cuales 4 animales (50\%) fueron positivos a la prueba ELISA, 2 (25\%) animales resultaron dudosos y 2 (25\%) animales negativos. De los 244 animales PCR negativos, $26(10,65 \%)$ resultaron positivos a la prueba ELISA con un índice superior a 900, 59 (24,18\%) fueron dudosos al presentar un índice entre 601 y 900, mientras que 159 $(65,16 \%)$ resultaron negativos a ambas pruebas (Tabla IV.22.). 
Tomando como referencia la PCR, y considerando a los animales con resultado dudoso como negativos, la prueba ELISA presentó una sensibilidad del 13,33\% y una especificidad del 98,19\%, con un índice kappa de 0,169, lo que indica una concordancia débil entre las dos técnicas diagnósticas. Cuando los animales con resultado dudoso se consideraron como positivos, la sensibilidad y especificidad fueron del 6,59\% y del 98,75\% respectivamente, con un índice kappa de 0,067 (concordancia débil).

\begin{tabular}{lccccc}
\hline \multicolumn{7}{c}{ ELISA } & & \\
& Positivos + & Dudosos $+/$ & Negativos & (Dudosos/Negativos) & TOTAL \\
\hline PCR + & 4 & 2 & 2 & 4 & $\mathbf{8}$ \\
PCR - & 26 & 59 & 159 & 218 & $\mathbf{2 4 4}$ \\
TOTAL & $\mathbf{3 0}$ & $\mathbf{6 1}$ & $\mathbf{1 6 1}$ & $\mathbf{2 2 2}$ & $\mathbf{2 5 2}$ \\
\hline
\end{tabular}

Tabla IV.22. Número de animales PCR (frente a Map) positivos y negativos al test ELISA frente a Map.

\subsection{7.- Relación entre el ELISA indirecto frente a paratuberculosis y tuberculosis.}

La técnica se llevó a cabo en 320 animales tanto frente a paratuberculosis como a tuberculosis; 58 animales $(18,12 \%)$ resultaron positivos a tuberculosis, de los cuales 15 $(25,86 \%)$ fueron positivos a la prueba ELISA frente a tuberculosis y a paratuberculosis y 43 animales $(74,14 \%)$ fueron positivos solo a tuberculosis con un índice superior a 800 . Mientras que 262 animales $(81,87 \%$ ) fueron negativos a tuberculosis, de los cuales 246 $(76,87 \%)$ resultaron negativos tanto a tuberculosis como a paratuberculosis. (Tabla IV.23.).

Considerando a los animales con resultado dudoso como negativos, se obtuvo un índice kappa de 0,676 , lo que indica una concordancia significativa entre tuberculosis y paratuberculosis.

\begin{tabular}{lccc}
\hline & ELISA PTB + & ELISA PTB & TOTAL \\
\hline ELISA TB + & 15 & 43 & 58 \\
ELISA TB - & 16 & 246 & 262 \\
TOTAL & 31 & 289 & 320 \\
\hline
\end{tabular}

Tabla IV.23. Número de animales positivos y negativos al test ELISA frente a M. bovis y Map. 


\section{IV.5. RESULTADO DE LAS DIFERENTES TÉCNICAS DIAGNÓSTICAS.}

En la siguiente tabla se muestra el porcentaje de animales positivos a las diferentes técnicas diagnósticos según el grupo (municipio). No se observaron diferencias significativas.

\begin{tabular}{cccccc}
\hline GRUPO & \% IDR & \%ELISA TB & $\begin{array}{c}\text { \% ELISA } \\
\text { PTB }\end{array}$ & \%PCR TB & $\begin{array}{c}\text { \%PCR } \\
\text { PTB }\end{array}$ \\
\hline A & 18,18 & 18,18 & 18,18 & 0 & 7,69 \\
B & 9,09 & 8,33 & 25 & 0 & 0 \\
C & 0 & 12,5 & 25 & 0 & 0 \\
D & 12,5 & 13,79 & 10,34 & 8,33 & 8,33 \\
E & 8,33 & 20 & 20 & 25 & 8,33 \\
F & 0 & 10 & 10 & 0 & 0 \\
G & 0 & 40 & 10 & 0 & 0 \\
H & 9,09 & 36,36 & 9,09 & 8,33 & 8,33 \\
I & 5,23 & 23,80 & 19,04 & 12,5 & 6,25 \\
J & 14,28 & 37,5 & 12,5 & 18,75 & 6,25 \\
K & 28,57 & 30 & 30 & 9,09 & 9,09 \\
L & 0 & 25 & 25 & 0 & 0 \\
M & 6,66 & 40 & 33,33 & 14,28 & 0 \\
N & 9,52 & 28 & 4 & 9,09 & 0 \\
O & 16,66 & 22,22 & 44,44 & 22,22 & 11,11 \\
P & 0 & 41,17 & 23,52 & 0 & 0 \\
Q & 6,45 & 18,75 & 15,62 & 3,70 & 3,70 \\
R & 0 & 33,33 & 25 & 7,69 & 0 \\
S & 11,62 & 12,76 & 10,63 & 3,70 & 3,70 \\
T & 14,28 & 71,42 & 28,57 & 0 & 14,28 \\
\hline
\end{tabular}

Tabla VI. 24. Porcentaje de animales positivos a las diferentes técnicas diagnósticas 


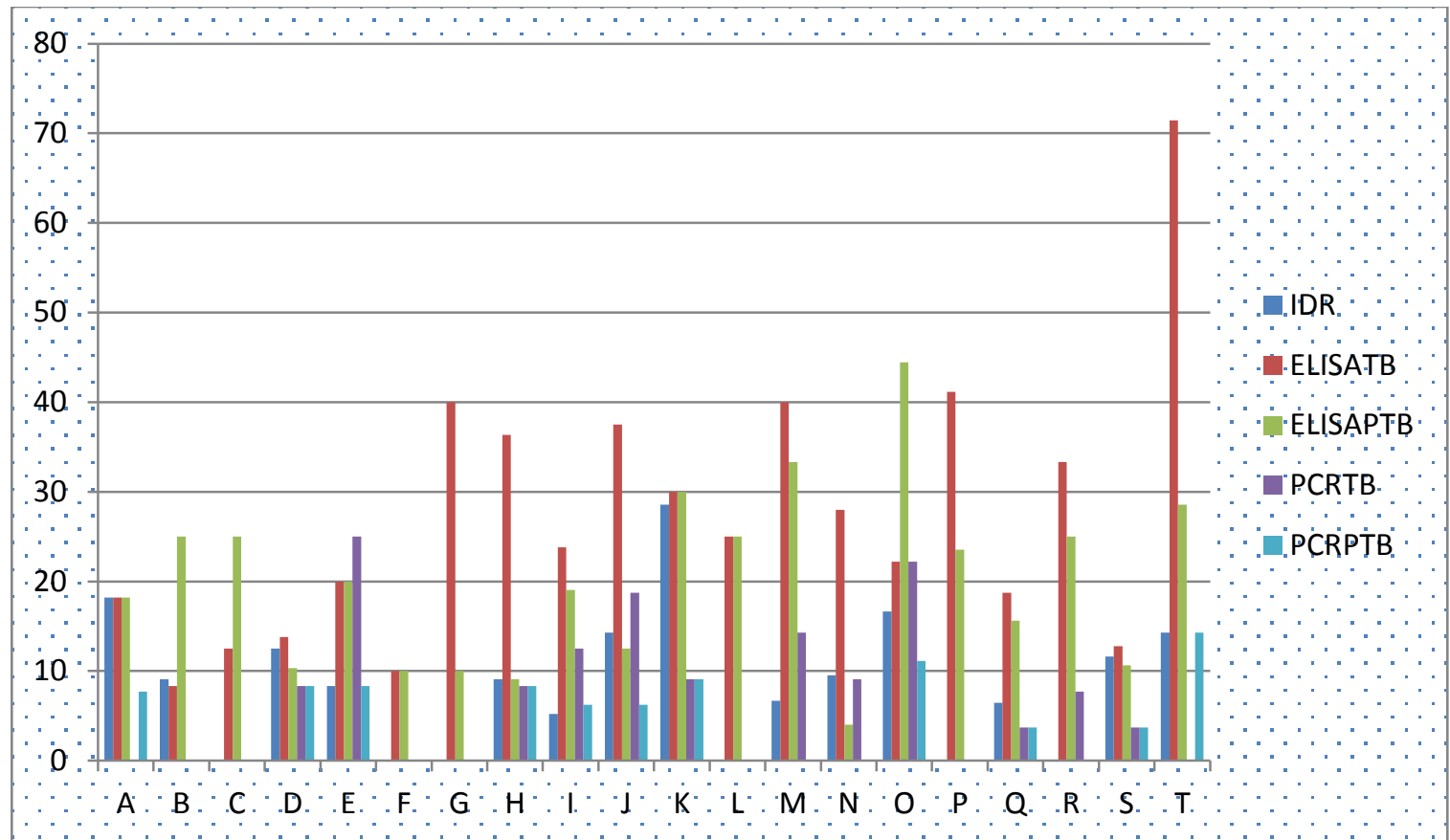

Gráfico IV.4. Porcentaje de la positividad de los grupos de animales a los que se aplicaron las diferentes técnicas diagnósticas.

5.1. Animales en los que se realizaron las diferentes técnicas diagnósticas, para tuberculosis y paratuberculosis.

En un total de 35 animales de diferentes grupos se llevaron a cabo las diferentes técnicas diagnósticas tanto para tuberculosis como para paratuberculosis. Dichos animales procedían de los 20 grupos (Tabla IV.25.).

\begin{tabular}{ccccccc}
\hline Identif. & $\begin{array}{c}\text { ELISA } \\
\text { TB }\end{array}$ & $\begin{array}{c}\text { PCR } \\
\text { TB }\end{array}$ & $\begin{array}{c}\text { IDR } \\
\text { bovina }\end{array}$ & Loc. Anat. & $\begin{array}{c}\text { ELISA } \\
\text { PTB }\end{array}$ & $\begin{array}{c}\text { PCR } \\
\text { PTB }\end{array}$ \\
\hline N5 & POS. & POS. & NEG. & GLC & DUD. & NEG. \\
N8 & NEG. & NEG. & NEG. & S/L & NEG. & NEG. \\
G3 & POS. & NEG. & NEG. & S/L & NEG. & NEG. \\
I6 & NEG. & POS. & NEG. & H/GLM & NEG. & NEG. \\
I7 & DUD. & NEG. & NEG. & GLC/GLP/GLM & DUD. & NEG. \\
I8 & NEG. & NEG. & NEG. & S/L & NEG. & NEG. \\
I9 & DUD. & NEG. & NEG. & GLP & NEG. & NEG. \\
L2 & NEG. & NEG. & NEG. & GLP/GLM & DUD. & NEG. \\
N12 & NEG. & NEG. & NEG. & GLM & NEG. & NEG. \\
E3 & DUD. & POS. & POS. & GLP & POS. & NEG. \\
\hline
\end{tabular}




\begin{tabular}{|c|c|c|c|c|c|c|}
\hline Q11 & DUD. & NEG. & POS. & S/L. & POS. & NEG. \\
\hline I12 & NEG. & NEG. & NEG. & GLC & NEG. & NEG. \\
\hline M8 & POS. & NEG. & POS. & GLC & POS. & NEG. \\
\hline A4 & DUD. & NEG. & NEG. & $\mathrm{S} / \mathrm{L}$ & NEG. & NEG. \\
\hline B5 & NEG. & NEG. & NEG. & GLM & NEG. & NEG. \\
\hline N15 & POS. & POS. & POS. & GLC/GLM & POS. & NEG. \\
\hline B7 & NEG. & NEG. & NEG. & $\mathrm{S} / \mathrm{L}$ & NEG. & NEG. \\
\hline A5 & NEG. & NEG. & NEG. & GLM & NEG. & NEG. \\
\hline Q14 & NEG. & NEG. & NEG. & $\mathrm{S} / \mathrm{L}$ & NEG. & NEG. \\
\hline D20 & DUD. & NEG. & NEG. & GLM & NEG. & NEG. \\
\hline C3 & DUD. & NEG. & NEG. & GLC & POS. & NEG. \\
\hline C4 & DUD. & NEG. & NEG. & GLC & NEG. & NEG. \\
\hline S39 & DUD. & NEG. & NEG. & GLM & POS. & NEG. \\
\hline D21 & POS. & NEG. & NEG. & GLM & DUD. & NEG. \\
\hline K5 & POS. & POS. & POS. & $\mathrm{S} / \mathrm{L}$ & POS. & NEG. \\
\hline N18 & DUD. & NEG. & NEG. & $\mathrm{S} / \mathrm{L}$ & NEG. & NEG. \\
\hline A10 & POS. & NEG. & NEG. & GLC/ & NEG. & NEG. \\
\hline M9 & POS. & POS. & NEG. & $\mathrm{S} / \mathrm{L}$ & NEG. & NEG. \\
\hline N20 & POS. & NEG. & NEG. & GLM & DUD. & NEG. \\
\hline R7 & POS. & NEG. & NEG. & $\mathrm{S} / \mathrm{L}$ & DUD. & NEG. \\
\hline O6 & POS. & POS. & NEG. & GLC & POS. & POS. \\
\hline S46 & POS. & POS. & NEG. & GLP & DUD. & NEG. \\
\hline H10 & POS. & POS. & POS. & $\mathrm{S} / \mathrm{L}$ & POS. & POS. \\
\hline N22 & POS. & NEG. & NEG. & GLC & DUD. & NEG. \\
\hline N24 & POS. & NEG. & NEG. & GLM & NEG. & NEG. \\
\hline
\end{tabular}

Tabla. IV.25. Resultado de las diferentes técnicas diagnósticas realizada en 35 animales. IDR bovina: Intradermorreacción. Loc. Anat.: Localización anatómica de la lesión. POS: Positivo. NEG: Negativo. DUD: Dudoso. GLC: Ganglios linfáticos de la cabeza. GLP: Ganglios linfáticos del pulmón. P: Pulmón. H: Hígado. GLM: Ganglios linfáticos mesentéricos. S/L: Sin lesión.

Todos los animales, excepto cinco, fueron positivos al menos a una de las pruebas de diagnóstico empleadas. 


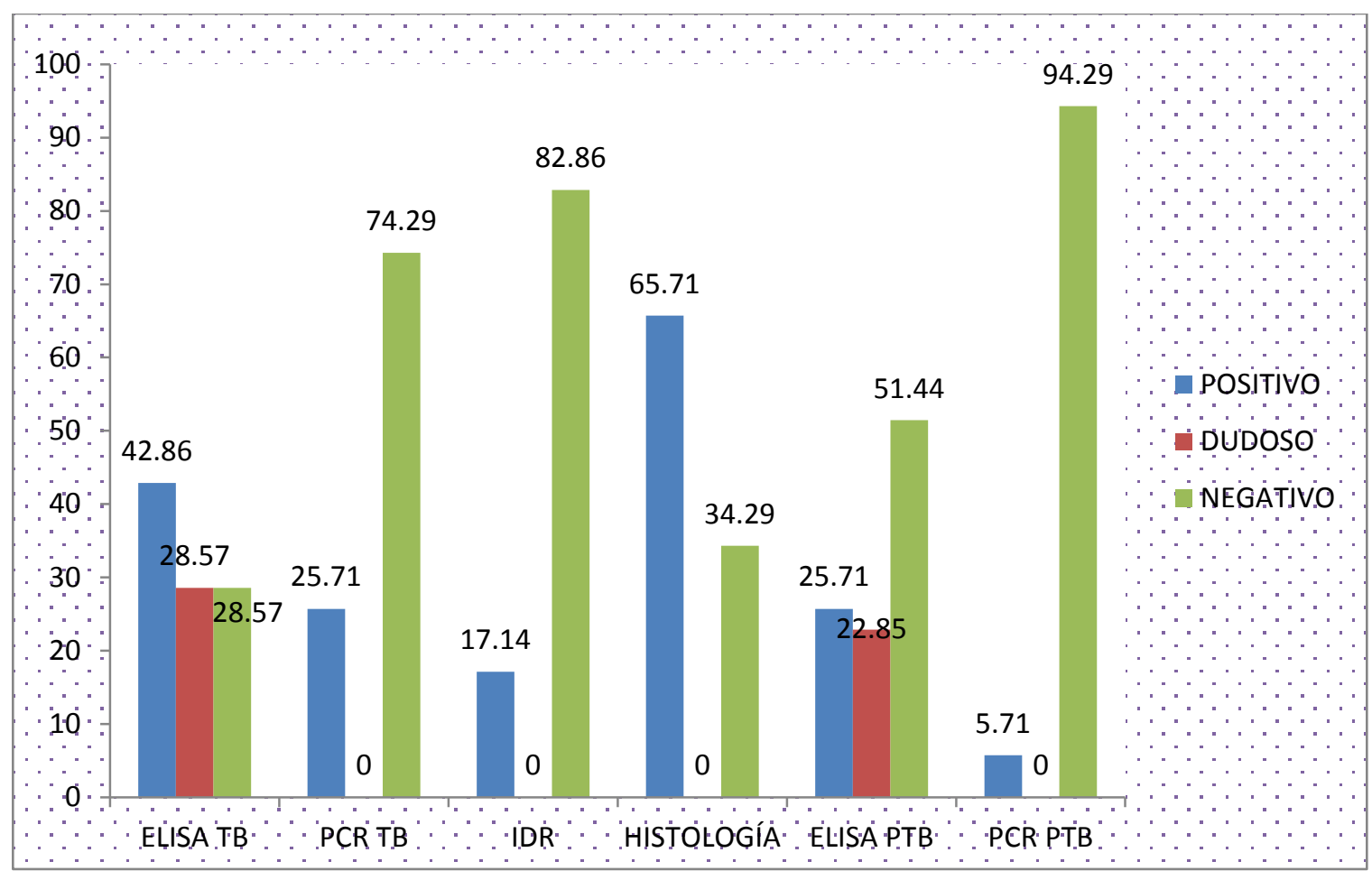

Gráfico VI.5. Resultado de las diferentes técnicas diagnósticas realizada en 35 animales, expresados como porcentaje de animales.

En la siguiente tabla se muestra una relación de todos los animales incluidos en el estudio, así como los resultados de todas las pruebas diagnósticas realizadas, incluyendo la localización anatómica de la lesión.

\begin{tabular}{ccccccc}
\hline Identif. & $\begin{array}{c}\text { Loc. de } \\
\text { la lesión }\end{array}$ & IDR & $\begin{array}{c}\text { ELISA } \\
\text { TB }\end{array}$ & $\begin{array}{c}\text { ELISA } \\
\text { PTB }\end{array}$ & PCR TB & PCR PTB \\
\hline S1 & SD & SD & 166 & 146 & SD & SD \\
S8 & SD & NEGATIVO & 296 & 394 & SD & SD \\
M1 & GLC & NEGATIVO & 424 & 338 & SD & SD \\
S2 & SD & NEGATIVO & 573 & 474 & SD & SD \\
S3 & SD & NEGATIVO & 714 & 518 & SD & SD \\
S4 & SD & NEGATIVO & 378 & 292 & SD & SD \\
S5 & SD & NEGATIVO & 719 & 267 & SD & SD \\
P1 & SD & NEGATIVO & 345 & 277 & SD & SD \\
P2 & SD & NEGATIVO & 481 & 264 & SD & SD \\
J1 & SD & NEGATIVO & 377 & 368 & SD & SD \\
C1 & SD & NEGATIVO & 418 & 470 & SD & SD \\
F1 & SD & NEGATIVO & 376 & 302 & SD & SD \\
B1 & SD & NEGATIVO & 291 & 263 & SD & SD \\
B2 & S/L & NEGATIVO & 316 & 267 & SD & SD \\
Q1 & SD & NEGATIVO & 644 & 485 & SD & SD \\
\hline
\end{tabular}




\begin{tabular}{|c|c|c|c|c|c|c|}
\hline N1 & SD & NEGATIVO & 349 & 467 & SD & SD \\
\hline S6 & SD & NEGATIVO & 286 & 229 & SD & SD \\
\hline N2 & SD & POSITIVO & 281 & 149 & SD & SD \\
\hline S7 & SD & NEGATIVO & 285 & 145 & SD & SD \\
\hline S8 & SD & NEGATIVO & 248 & 202 & SD & SD \\
\hline F2 & SD & NEGATIVO & 569 & 508 & SD & SD \\
\hline F3 & SD & NEGATIVO & 417 & 421 & SD & SD \\
\hline $\mathbf{J} 2$ & SD & NEGATIVO & 513 & 379 & SD & SD \\
\hline S9 & SD & SD & 325 & 281 & SD & SD \\
\hline S10 & SD & SD & 371 & 248 & SD & SD \\
\hline S11 & SD & SD & 403 & 219 & SD & SD \\
\hline Q2 & SD & NEGATIVO & 332 & 227 & SD & SD \\
\hline N3 & $\mathrm{P}$ & NEGATIVO & 375 & 199 & SD & SD \\
\hline I2 & SD & NEGATIVO & 837 & 819 & SD & SD \\
\hline P3 & SD & SD & 963 & 588 & SD & SD \\
\hline S12 & SD & NEGATIVO & 975 & 455 & SD & SD \\
\hline S13 & SD & NEGTIVO & 573 & 518 & SD & SD \\
\hline Q3 & SD & SD & 410 & 222 & SD & SD \\
\hline Q4 & $\mathrm{S} / \mathrm{L}$ & NEGATIVO & 639 & 440 & SD & SD \\
\hline I3 & GLP & NEGATIVO & 647 & 544 & SD & SD \\
\hline D1 & $\mathrm{S} / \mathrm{L}$ & NEGATIVO & 470 & 677 & SD & SD \\
\hline S14 & GLP & NEGATIVO & 602 & 217 & SD & SD \\
\hline S15 & SD & NEGATIVO & 592 & 406 & SD & $\mathrm{SD}$ \\
\hline S16 & $\mathrm{S} / \mathrm{L}$ & POSITIVO & 498 & 369 & SD & $\mathrm{SD}$ \\
\hline S17 & SD & POSITIVO & 345 & 457 & SD & SD \\
\hline S18 & GLP-P & NEGATIVO & 618 & 310 & SD & SD \\
\hline S19 & SD & NEGATIVO & 554 & 252 & SD & SD \\
\hline Q5 & GLC & NEGATIVO & 739 & 363 & SD & SD \\
\hline $\mathbf{S 2 0}$ & SD & NEGATIVO & 607 & 737 & SD & SD \\
\hline D2 & SD & NEGATIVO & 521 & 329 & SD & SD \\
\hline M2 & GLP & NEGATIVO & 545 & 634 & SD & SD \\
\hline D3 & SD & NEGATIVO & 595 & 571 & SD & SD \\
\hline D4 & SD & POSITIVO & 461 & 403 & SD & SD \\
\hline D5 & GLP & NEGATIVO & 621 & 638 & SD & SD \\
\hline D6 & $\mathrm{S} / \mathrm{L}$ & NEGATIVO & 633 & 251 & SD & SD \\
\hline D7 & $\mathrm{S} / \mathrm{L}$ & NEGATIVO & 655 & 533 & SD & SD \\
\hline D8 & SD & SD & 481 & 322 & SD & SD \\
\hline Q6 & SD & NEGATIVO & 500 & 537 & SD & SD \\
\hline M3 & $S / L$ & NEGATIVO & 726 & 663 & SD & SD \\
\hline D9 & SD & NEGATIVO & 440 & 470 & SD & SD \\
\hline D10 & $\mathrm{S} / \mathrm{L}$ & NEGATIVO & 569 & 684 & SD & SD \\
\hline D11 & $\mathrm{S} / \mathrm{L}$ & NEGATIVO & 656 & 347 & SD & SD \\
\hline D12 & $\mathrm{S} / \mathrm{L}$ & NEGATIVO & 469 & 875 & SD & SD \\
\hline D13 & $\begin{array}{l}\text { GLC- } \\
\text { GLP-P }\end{array}$ & NEGATIVO & 667 & 585 & SD & SD \\
\hline C2 & $\mathrm{S} / \mathrm{L}$ & NEGATIVO & 337 & 913 & SD & SD \\
\hline
\end{tabular}




\begin{tabular}{|c|c|c|c|c|c|c|}
\hline D14 & SD & POSITIVO & 594 & 234 & SD & SD \\
\hline D15 & $\mathrm{S} / \mathrm{L}$ & NEGATIVO & 209 & 685 & SD & SD \\
\hline I4 & SD & NEGATIVO & 407 & 178 & SD & SD \\
\hline D16 & SD & NEGATIVO & 518 & 451 & SD & SD \\
\hline I5 & SD & NEGATIVO & 252 & 252 & SD & SD \\
\hline D17 & SD & NEGATIVO & 385 & 385 & SD & SD \\
\hline D18 & SD & NEGATIVO & 510 & 510 & SD & SD \\
\hline D19 & SD & NEGATIVO & 634 & 661 & SD & SD \\
\hline S21 & SD & NEGATIVO & 474 & 572 & NEGATIVO & NEGATIVO \\
\hline S22 & SD & NEGATIVO & 765 & 556 & NEGATIVO & NEGATIVO \\
\hline S23 & SD & NEGATIVO & 453 & 398 & NEGATIVO & NEGATIVO \\
\hline S24 & SD & NEGATIVO & 630 & 849 & NEGATIVO & NEGATIVO \\
\hline S25 & SD & POSITIVO & 409 & 336 & NEGATIVO & NEGATIVO \\
\hline S26 & SD & NEGATIVO & 436 & 316 & NEGATIVO & NEGATIVO \\
\hline S27 & SD & NEGATIVO & 738 & 378 & NEGATIVO & POSITIVO \\
\hline E1 & SD & NEGATIVO & 388 & 261 & NEGATIVO & NEGATIVO \\
\hline N4 & SD & NEGATIVO & 677 & 617 & NEGATIVO & NEGATIVO \\
\hline N5 & GLC & NEGATIVO & 1033 & 657 & POSITIVO & NEGATIVO \\
\hline N6 & SD & SD & 394 & 486 & NEGATIVO & NEGATIVO \\
\hline N7 & SD & SD & 239 & 280 & NEGATIVO & NEGATIVO \\
\hline N8 & $\mathrm{S} / \mathrm{L}$ & NEGATIVO & 278 & 344 & NEGATIVO & NEGATIVO \\
\hline S28 & SD & NEGATIVO & 238 & 154 & NEGATIVO & NEGATIVO \\
\hline S29 & SD & NEGATIVO & 143 & 194 & NEGATIVO & NEGATIVO \\
\hline S30 & SD & POSITIVO & 571 & 651 & NEGATIVO & NEGATIVO \\
\hline S31 & SD & NEGATIVO & 183 & 237 & NEGATIVO & NEGATIVO \\
\hline S32 & SD & NEGATIVO & 655 & 674 & NEGATIVO & NEGATIVO \\
\hline G1 & SD & NEGATIVO & 266 & 718 & NEGATIVO & NEGATIVO \\
\hline G2 & SD & NEGATIVO & 182 & 226 & NEGATIVO & NEGATIVO \\
\hline G3 & $\mathrm{S} / \mathrm{L}$ & NEGATIVO & 823 & 413 & NEGATIVO & NEGATIVO \\
\hline K1 & SD & POSITIVO & 330 & 767 & NEGATIVO & NEGATIVO \\
\hline T1 & SD & NEGATIVO & 712 & 585 & NEGATIVO & NEGATIVO \\
\hline I6 & S/L & NEGATIVO & 322 & 455 & POSITIVO & NEGATIVO \\
\hline I7 & $\begin{array}{l}\text { GLC- } \\
\text { GLP }\end{array}$ & NEGATIVO & 622 & 844 & NEGATIVO & NEGATIVO \\
\hline I8 & $\mathrm{S} / \mathrm{L}$ & NEGATIVO & 406 & 323 & NEGATIVO & NEGATIVO \\
\hline I9 & GLP & NEGATIVO & 764 & 462 & NEGATIVO & NEGATIVO \\
\hline H1 & SD & SD & 582 & 117 & NEGATIVO & NEGATIVO \\
\hline J3 & SD & NEGATIVO & 1002 & 628 & NEGATIVO & NEGATIVO \\
\hline J4 & $\begin{array}{l}\text { GLC- } \\
\text { GLP }\end{array}$ & SD & 683 & 263 & NEGATIVO & NEGATIVO \\
\hline I10 & SD & NEGATIVO & 419 & 234 & NEGATIVO & NEGATIVO \\
\hline S33 & SD & NEGATIVO & 583 & 411 & NEGATIVO & NEGATIVO \\
\hline S34 & SD & NEGATIVO & 511 & 606 & NEGATIVO & NEGATIVO \\
\hline S35 & SD & NEGATIVO & 568 & 538 & NEGATIVO & NEGATIVO \\
\hline E2 & SD & NEGATIVO & 532 & 318 & NEGATIVO & NEGATIVO \\
\hline L1 & SD & NEGATIVO & 163 & 95 & NEGATIVO & NEGATIVO \\
\hline
\end{tabular}




\begin{tabular}{|c|c|c|c|c|c|c|}
\hline L2 & GLP & NEGATIVO & 158 & 643 & NEGATIVO & NEGATIVO \\
\hline $\mathbf{L 3}$ & SD & SD & 864 & 1011 & NEGATIVO & NEGATIVO \\
\hline A1 & SD & SD & 433 & 546 & NEGATIVO & NEGATIVO \\
\hline A2 & SD & SD & 265 & 272 & NEGATIVO & NEGATIVO \\
\hline F4 & SD & SD & 701 & 484 & NEGATIVO & NEGATIVO \\
\hline 01 & SD & SD & 359 & 331 & NEGATIVO & NEGATIVO \\
\hline $\mathbf{O 2}$ & SD & SD & 405 & 782 & NEGATIVO & NEGATIVO \\
\hline $\mathbf{O 3}$ & SD & POSITIVO & 394 & 415 & POSITIVO & NEGATIVO \\
\hline N9 & SD & NEGATIVO & 158 & 136 & NEGATIVO & NEGATIVO \\
\hline N10 & SD & NEGATIVO & 472 & 188 & NEGATIVO & NEGATIVO \\
\hline N11 & SD & NEGATIVO & 288 & 206 & NEGATIVO & NEGATIVO \\
\hline N12 & $\mathrm{S} / \mathrm{L}$ & NEGATIVO & 271 & 324 & NEGATIVO & NEGATIVO \\
\hline Q7 & SD & NEGATIVO & 568 & 869 & NEGATIVO & NEGATIVO \\
\hline Q8 & SD & NEGATIVO & 371 & 692 & NEGATIVO & NEGATIVO \\
\hline Q9 & SD & NEGATIVO & 234 & 880 & NEGATIVO & NEGATIVO \\
\hline S36 & SD & NEGATIVO & 440 & 314 & NEGATIVO & NEGATIVO \\
\hline J5 & SD & NEGATIVO & 665 & 403 & NEGATIVO & NEGATIVO \\
\hline J6 & SD & NEGATIVO & 484 & 369 & NEGATIVO & NEGATIVO \\
\hline J7 & SD & NEGATIVO & 332 & 281 & NEGATIVO & NEGATIVO \\
\hline E3 & GLP & POSITIVO & 620 & 1260 & POSITIVO & NEGATIVO \\
\hline E4 & $\mathrm{SD}$ & NEGATIVO & 304 & 195 & NEGATIVO & NEGATIVO \\
\hline E5 & SD & NEGATIVO & 482 & 480 & NEGATIVO & NEGATIVO \\
\hline B3 & SD & NEGATIVO & 656 & 1186 & NEGATIVO & NEGATIVO \\
\hline B4 & SD & SD & 616 & 605 & NEGATIVO & NEGATIVO \\
\hline N13 & SD & NEGATIVO & 477 & 432 & NEGATIVO & NEGATIVO \\
\hline N14 & SD & SD & 538 & 670 & NEGATIVO & NEGATIVO \\
\hline M4 & SD & NEGATIVO & 260 & 508 & POSITIVO & NEGATIVO \\
\hline M5 & SD & NEGATIVO & 798 & 886 & NEGATIVO & NEGATIVO \\
\hline Q10 & SD & NEGATIVO & 450 & 576 & NEGATIVO & NEGATIVO \\
\hline Q11 & $\mathrm{S} / \mathrm{L}$ & POSITIVO & 618 & 975 & NEGATIVO & NEGATIVO \\
\hline Q12 & SD & NEGATIVO & 500 & 529 & NEGATIVO & NEGATIVO \\
\hline Q13 & SD & NEGATIVO & 600 & 656 & NEGATIVO & NEGATIVO \\
\hline I11 & SD & NEGATIVO & 442 & 579 & NEGATIVO & NEGATIVO \\
\hline I12 & GLC & NEGATIVO & 392 & 448 & NEGATIVO & NEGATIVO \\
\hline M6 & SD & NEGATIVO & 468 & 446 & NEGATIVO & NEGATIVO \\
\hline M7 & SD & NEGATIVO & 663 & 933 & NEGATIVO & NEGATIVO \\
\hline M8 & GLC & POSITIVO & 993 & 1495 & NEGATIVO & NEGATIVO \\
\hline K2 & SD & NEGATIVO & 651 & 609 & NEGATIVO & NEGATIVO \\
\hline K3 & SD & POSITIVO & 773 & 748 & NEGATIVO & NEGATIVO \\
\hline P4 & SD & NEGATIVO & 591 & 657 & NEGATIVO & NEGATIVO \\
\hline F5 & SD & NEGATIVO & 456 & 551 & NEGATIVO & NEGATIVO \\
\hline P5 & $\mathrm{SD}$ & NEGATIVO & 558 & 621 & NEGATIVO & NEGATIVO \\
\hline P6 & SD & NEGATIVO & 454 & 855 & NEGATIVO & NEGATIVO \\
\hline $\mathbf{T} 2$ & SD & NEGATIVO & 906 & 837 & NEGATIVO & NEGATIVO \\
\hline A3 & SD & POSITIVO & 972 & 927 & NEGATIVO & NEGATIVO \\
\hline A4 & $\mathrm{S} / \mathrm{L}$ & NEGATIVO & 504 & 145 & NEGATIVO & NEGATIVO \\
\hline
\end{tabular}




\begin{tabular}{|c|c|c|c|c|c|c|}
\hline B5 & $\mathrm{S} / \mathrm{L}$ & NEGATIVO & 435 & 353 & NEGATIVO & NEGATIVO \\
\hline N15 & GLC & POSITIVO & 1108 & 1314 & POSITIVO & NEGATIVO \\
\hline B6 & SD & NEGATIVO & 408 & 175 & NEGATIVO & NEGATIVO \\
\hline B7 & $\mathrm{S} / \mathrm{L}$ & NEGATIVO & 337 & 274 & NEGATIVO & NEGATIVO \\
\hline I13 & SD & NEGATIVO & 422 & 338 & NEGATIVO & NEGATIVO \\
\hline A5 & $\mathrm{S} / \mathrm{L}$ & NEGATIVO & 394 & 449 & NEGATIVO & NEGATIVO \\
\hline A6 & $\mathrm{SD}$ & NEGATIVO & 507 & 610 & NEGATIVO & NEGATIVO \\
\hline S37 & SD & NEGATIVO & 854 & 795 & NEGATIVO & NEGATIVO \\
\hline N16 & $\mathrm{SD}$ & NEGATIVO & 354 & 206 & NEGATIVO & NEGATIVO \\
\hline Q14 & $\mathrm{S} / \mathrm{L}$ & NEGATIVO & 336 & 237 & NEGATIVO & NEGATIVO \\
\hline D20 & $\mathrm{S} / \mathrm{L}$ & NEGATIVO & 654 & 584 & NEGATIVO & NEGATIVO \\
\hline C3 & GLC & NEGATIVO & 558 & 939 & NEGATIVO & NEGATIVO \\
\hline $\mathrm{C} 4$ & GLC & NEGATIVO & 520 & 269 & NEGATIVO & NEGATIVO \\
\hline C5 & SD & NEGATIVO & 420 & 374 & NEGATIVO & NEGATIVO \\
\hline S38 & SD & NEGATIVO & 523 & 720 & NEGATIVO & NEGATIVO \\
\hline S39 & $\mathrm{S} / \mathrm{L}$ & NEGATIVO & 741 & 1124 & NEGATIVO & NEGATIVO \\
\hline S40 & $\mathrm{SD}$ & NEGATIVO & 546 & 586 & NEGATIVO & NEGATIVO \\
\hline S41 & SD & NEGATIVO & 399 & 348 & NEGATIVO & NEGATIVO \\
\hline L4 & SD & NEGATIVO & 278 & 192 & NEGATIVO & NEGATIVO \\
\hline $\mathbf{L 5}$ & SD & $\mathrm{SD}$ & 56 & 391 & NEGATIVO & NEGATIVO \\
\hline H2 & SD & NEGATIVO & 543 & 387 & NEGATIVO & NEGATIVO \\
\hline H3 & SD & NEGATIVO & 538 & 480 & NEGATIVO & NEGATIVO \\
\hline B8 & SD & SD & 602 & 543 & NEGATIVO & NEGATIVO \\
\hline B9 & SD & POSITIVO & 807 & 934 & NEGATIVO & NEGATIVO \\
\hline B10 & $\mathrm{SD}$ & NEGATIVO & 343 & 314 & NEGATIVO & NEGATIVO \\
\hline Q15 & SD & NEGATIVO & 383 & 279 & NEGATIVO & NEGATIVO \\
\hline H4 & SD & NEGATIVO & 512 & 438 & NEGATIVO & NEGATIVO \\
\hline Q16 & SD & NEGATIVO & 840 & 446 & NEGATIVO & NEGATIVO \\
\hline Q17 & SD & NEGATIVO & 346 & 468 & NEGATIVO & NEGATIVO \\
\hline P7 & SD & NEGATIVO & 569 & 433 & NEGATIVO & NEGATIVO \\
\hline P8 & SD & NEGATIVO & 515 & 1189 & NEGATIVO & NEGATIVO \\
\hline P9 & SD & NEGATIVO & 614 & 339 & NEGATIVO & NEGATIVO \\
\hline N17 & SD & $\mathrm{SD}$ & 825 & 679 & NEGATIVO & NEGATIVO \\
\hline I14 & $\mathrm{SD}$ & NEGATIVO & 607 & 600 & NEGATIVO & NEGATIVO \\
\hline I15 & SD & SD & 632 & 370 & NEGATIVO & NEGATIVO \\
\hline R1 & $\mathrm{SD}$ & SD & 559 & 291 & NEGATIVO & NEGATIVO \\
\hline S42 & SD & NEGATIVO & 372 & 275 & NEGATIVO & NEGATIVO \\
\hline S43 & $\mathrm{SD}$ & NEGATIVO & 541 & 326 & NEGATIVO & NEGATIVO \\
\hline F6 & SD & NEGATIVO & 565 & 446 & NEGATIVO & NEGATIVO \\
\hline A7 & SD & NEGATIVO & 533 & 809 & NEGATIVO & NEGATIVO \\
\hline E6 & $\mathrm{SD}$ & NEGATIVO & 713 & 463 & NEGATIVO & NEGATIVO \\
\hline 04 & $\mathrm{~S} / \mathrm{L}$ & SD & 805 & 1009 & NEGATIVO & NEGATIVO \\
\hline Q18 & $\mathrm{SD}$ & NEGATIVO & 564 & 426 & NEGATIVO & NEGATIVO \\
\hline Q19 & SD & NEGATIVO & 560 & 457 & NEGATIVO & NEGATIVO \\
\hline Q20 & SD & NEGATIVO & 752 & 417 & NEGATIVO & NEGATIVO \\
\hline Q21 & SD & POSITIVO & 712 & 1060 & NEGATIVO & NEGATIVO \\
\hline
\end{tabular}




\begin{tabular}{|c|c|c|c|c|c|c|}
\hline Q22 & SD & NEGATIVO & 533 & 432 & NEGATIVO & NEGATIVO \\
\hline Q23 & SD & NEGATIVO & 824 & 547 & NEGATIVO & NEGATIVO \\
\hline Q24 & SD & NEGATIVO & 238 & 119 & NEGATIVO & NEGATIVO \\
\hline Q25 & SD & NEGATIVO & 740 & 349 & POSITIVO & NEGATIVO \\
\hline Q26 & SD & NEGATIVO & 891 & 508 & NEGATIVO & NEGATIVO \\
\hline H5 & SD & NEGATIVO & 804 & 458 & NEGATIVO & NEGATIVO \\
\hline H6 & SD & NEGATIVO & 697 & 292 & NEGATIVO & NEGATIVO \\
\hline D21 & $\mathrm{S} / \mathrm{L}$ & NEGATIVO & 1067 & 806 & NEGATIVO & NEGATIVO \\
\hline D22 & SD & NEGATIVO & 824 & 428 & NEGATIVO & NEGATIVO \\
\hline J8 & SD & NEGATIVO & 791 & 510 & NEGATIVO & NEGATIVO \\
\hline J9 & SD & NEGATIVO & 650 & 501 & NEGATIVO & NEGATIVO \\
\hline J10 & SD & NEGATIVO & 479 & 418 & NEGATIVO & NEGATIVO \\
\hline K4 & SD & NEGATIVO & 401 & 267 & NEGATIVO & NEGATIVO \\
\hline P10 & SD & NEGATIVO & 754 & 546 & NEGATIVO & NEGATIVO \\
\hline P11 & SD & NEGATIVO & 779 & 503 & NEGATIVO & NEGATIVO \\
\hline K5 & $\mathrm{S} / \mathrm{L}$ & POSITIVO & 883 & 957 & POSITIVO & NEGATIVO \\
\hline $\mathbf{R} 2$ & SD & NEGATIVO & 634 & 461 & NEGATIVO & NEGATIVO \\
\hline R3 & SD & NEGATIVO & 581 & 322 & NEGATIVO & NEGATIVO \\
\hline H7 & SD & NEGATIVO & 883 & 502 & NEGATIVO & NEGATIVO \\
\hline E7 & SD & NEGATIVO & 846 & 385 & POSITIVO & NEGATIVO \\
\hline 05 & SD & NEGATIVO & 755 & 614 & NEGATIVO & NEGATIVO \\
\hline N18 & $\mathrm{S} / \mathrm{L}$ & NEGATIVO & 609 & 493 & NEGATIVO & NEGATIVO \\
\hline I16 & SD & POSITIVO & 947 & 1114 & POSITIVO & POSITIVO \\
\hline F7 & SD & NEGATIVO & 599 & 365 & NEGATIVO & NEGATIVO \\
\hline S44 & SD & NEGATIVO & 673 & 408 & NEGATIVO & NEGATIVO \\
\hline H8 & SD & NEGATIVO & 552 & 449 & NEGATIVO & NEGATIVO \\
\hline P12 & SD & NEGATIVO & 621 & 482 & NEGATIVO & NEGATIVO \\
\hline A8 & SD & NEGATIVO & 579 & 369 & NEGATIVO & NEGATIVO \\
\hline A9 & SD & NEGATIVO & 413 & 220 & NEGATIVO & NEGATIVO \\
\hline A10 & GLC & NEGATIVO & 1000 & 428 & NEGATIVO & NEGATIVO \\
\hline A11 & SD & POSITIVO & 674 & 266 & NEGATIVO & NEGATIVO \\
\hline J11 & SD & SD & 1089 & 794 & POSITIVO & NEGATIVO \\
\hline T3 & SD & NEGATIVO & 602 & 365 & NEGATIVO & NEGATIVO \\
\hline T4 & SD & NEGATIVO & 821 & 165 & NEGATIVO & POSITIVO \\
\hline M9 & $\mathrm{S} / \mathrm{L}$ & NEGATIVO & 982 & 517 & POSITIVO & NEGATIVO \\
\hline M10 & SD & NEGATIVO & 840 & 236 & NEGATIVO & NEGATIVO \\
\hline N19 & SD & POSITIVO & 705 & 611 & NEGATIVO & NEGATIVO \\
\hline N20 & $\mathrm{S} / \mathrm{L}$ & NEGATIVO & 1244 & 666 & NEGATIVO & NEGATIVO \\
\hline Q27 & SD & NEGATIVO & 684 & 287 & NEGATIVO & NEGATIVO \\
\hline Q28 & SD & NEGATIVO & 582 & 373 & NEGATIVO & NEGATIVO \\
\hline Q29 & SD & NEGATIVO & 481 & 881 & NEGATIVO & POSITIVO \\
\hline D23 & SD & SD & 242 & 392 & NEGATIVO & NEGATIVO \\
\hline F8 & SD & NEGATIVO & 581 & 1108 & NEGATIVO & NEGATIVO \\
\hline F9 & SD & NEGATIVO & 955 & 622 & NEGATIVO & NEGATIVO \\
\hline G4 & SD & SD & 779 & 1020 & NEGATIVO & NEGATIVO \\
\hline I17 & SD & NEGATIVO & 474 & 490 & NEGATIVO & NEGATIVO \\
\hline
\end{tabular}




\begin{tabular}{|c|c|c|c|c|c|c|}
\hline L6 & SD & NEGATIVO & 508 & 541 & NEGATIVO & NEGATIVO \\
\hline L7 & SD & NEGATIVO & 801 & 876 & NEGATIVO & NEGATIVO \\
\hline G5 & SD & SD & 509 & 535 & NEGATIVO & NEGATIVO \\
\hline I18 & SD & NEGATIVO & 864 & 634 & NEGATIVO & NEGATIVO \\
\hline I19 & SD & NEGATIVO & 760 & 352 & NEGATIVO & NEGATIVO \\
\hline R4 & SD & NEGATIVO & 526 & 843 & NEGATIVO & NEGATIVO \\
\hline R5 & SD & NEGATIVO & 566 & 134 & NEGATIVO & NEGATIVO \\
\hline $\mathbf{N} 21$ & SD & NEGATIVO & 365 & 551 & NEGATIVO & NEGATIVO \\
\hline M11 & SD & NEGATIVO & 573 & 972 & NEGATIVO & NEGATIVO \\
\hline M12 & SD & NEGATIVO & 731 & 425 & NEGATIVO & NEGATIVO \\
\hline D24 & SD & POSITIVO & 668 & 738 & NEGATIVO & NEGATIVO \\
\hline D25 & SD & SD & 660 & 505 & NEGATIVO & NEGATIVO \\
\hline B11 & SD & NEGATIVO & 375 & 729 & NEGATIVO & NEGATIVO \\
\hline B12 & SD & NEGATIVO & 520 & 264 & NEGATIVO & NEGATIVO \\
\hline R6 & SD & SD & 746 & 1095 & NEGATIVO & NEGATIVO \\
\hline K6 & SD & SD & 711 & 1324 & NEGATIVO & NEGATIVO \\
\hline Q30 & SD & NEGATIVO & 866 & 1568 & NEGATIVO & NEGATIVO \\
\hline Q31 & SD & NEGATIVO & 500 & 380 & NEGATIVO & NEGATIVO \\
\hline I20 & SD & NEGATIVO & 672 & 791 & NEGATIVO & NEGATIVO \\
\hline I21 & SD & $\mathrm{SD}$ & 593 & 137 & NEGATIVO & NEGATIVO \\
\hline E8 & SD & NEGATIVO & 557 & 245 & NEGATIVO & NEGATIVO \\
\hline E9 & SD & NEGATIVO & 658 & 954 & NEGATIVO & NEGATIVO \\
\hline S45 & SD & NEGATIVO & 759 & 814 & NEGATIVO & NEGATIVO \\
\hline T5 & SD & NEGATIVO & 754 & 760 & NEGATIVO & NEGATIVO \\
\hline T6 & $\mathrm{SD}$ & POSITIVO & 775 & 643 & NEGATIVO & NEGATIVO \\
\hline T7 & SD & NEGATIVO & 798 & 585 & NEGATIVO & NEGATIVO \\
\hline R7 & $\mathrm{S} / \mathrm{L}$ & NEGATIVO & 1050 & 691 & NEGATIVO & NEGATIVO \\
\hline R8 & SD & NEGATIVO & 722 & 815 & NEGATIVO & NEGATIVO \\
\hline P13 & SD & NEGATIVO & 750 & 957 & NEGATIVO & NEGATIVO \\
\hline K7 & $\mathrm{SD}$ & SD & 318 & 581 & NEGATIVO & NEGATIVO \\
\hline J12 & SD & SD & 642 & 885 & NEGATIVO & NEGATIVO \\
\hline D26 & SD & SD & 1343 & 1210 & POSITIVO & POSITIVO \\
\hline D27 & SD & $\mathrm{SD}$ & 798 & 443 & NEGATIVO & NEGATIVO \\
\hline M13 & $\mathrm{SD}$ & NEGATIVO & 932 & 1269 & NEGATIVO & NEGATIVO \\
\hline 06 & GLC & NEGATIVO & 910 & 1338 & POSITIVO & NEGATIVO \\
\hline $\mathbf{O 7}$ & $\mathrm{SD}$ & NEGATIVO & 746 & 792 & NEGATIVO & NEGATIVO \\
\hline R9 & SD & $\mathrm{SD}$ & 1052 & 721 & POSITIVO & NEGATIVO \\
\hline P14 & $\mathrm{SD}$ & NEGATIVO & 527 & 359 & NEGATIVO & NEGATIVO \\
\hline R10 & SD & SD & 504 & 310 & NEGATIVO & NEGATIVO \\
\hline R11 & SD & SD & 1045 & 542 & NEGATIVO & NEGATIVO \\
\hline E10 & $\mathrm{SD}$ & NEGATIVO & 794 & 492 & NEGATIVO & NEGATIVO \\
\hline S46 & GLP & NEGATIVO & 973 & 613 & POSITIVO & NEGATIVO \\
\hline S47 & $\mathrm{SD}$ & NEGATIVO & 1532 & 1703 & NEGATIVO & NEGATIVO \\
\hline J13 & SD & POSITIVO & 1080 & 679 & POSITIVO & NEGATIVO \\
\hline J14 & SD & SD & 951 & 554 & NEGATIVO & NEGATIVO \\
\hline H9 & SD & NEGATIVO & 756 & 425 & NEGATIVO & NEGATIVO \\
\hline
\end{tabular}




\begin{tabular}{|c|c|c|c|c|c|c|}
\hline H10 & $\mathrm{S} / \mathrm{L}$ & POSITIVO & 1443 & 1209 & POSITIVO & POSITIVO \\
\hline M14 & SD & NEGATIVO & 836 & 648 & NEGATIVO & NEGATIVO \\
\hline $\mathbf{N} 22$ & GLC & NEGATIVO & 1940 & 723 & NEGATIVO & NEGATIVO \\
\hline G6 & $\mathrm{SD}$ & NEGATIVO & 866 & 460 & NEGATIVO & NEGATIVO \\
\hline G7 & SD & NEGATIVO & 688 & 552 & NEGATIVO & NEGATIVO \\
\hline K8 & SD & SD & 738 & 289 & NEGATIVO & NEGATIVO \\
\hline G8 & SD & NEGATIVO & 937 & 611 & NEGATIVO & NEGATIVO \\
\hline L8 & SD & NEGATIVO & 744 & 381 & NEGATIVO & NEGATIVO \\
\hline G9 & SD & NEGATIVO & 678 & 363 & NEGATIVO & NEGATIVO \\
\hline Q32 & SD & SD & 874 & 495 & NEGATIVO & NEGATIVO \\
\hline P15 & SD & NEGATIVO & 1081 & 729 & NEGATIVO & NEGATIVO \\
\hline P16 & SD & NEGATIVO & 777 & 566 & NEGATIVO & NEGATIVO \\
\hline D28 & SD & NEGATIVO & 696 & 364 & NEGATIVO & NEGATIVO \\
\hline M15 & SD & NEGATIVO & 700 & 425 & NEGATIVO & NEGATIVO \\
\hline D29 & SD & NEGATIVO & 626 & 412 & NEGATIVO & NEGATIVO \\
\hline K9 & SD & NEGATIVO & 807 & 679 & NEGATIVO & POSITIVO \\
\hline $\mathbf{N} 23$ & SD & NEGATIVO & 440 & 395 & NEGATIVO & NEGATIVO \\
\hline $\mathrm{N} 24$ & $\mathrm{~S} / \mathrm{L}$ & NEGATIVO & 975 & 562 & NEGATIVO & NEGATIVO \\
\hline $\mathbf{N} 25$ & SD & NEGATIVO & 843 & 620 & NEGATIVO & NEGATIVO \\
\hline P17 & SD & NEGATIVO & 825 & 909 & NEGATIVO & NEGATIVO \\
\hline R12 & SD & NEGATIVO & 787 & 464 & NEGATIVO & NEGATIVO \\
\hline J15 & SD & NEGATIVO & 839 & 388 & NEGATIVO & NEGATIVO \\
\hline C6 & SD & NEGATIVO & 680 & 326 & NEGATIVO & NEGATIVO \\
\hline C7 & SD & SD & 650 & 582 & NEGATIVO & NEGATIVO \\
\hline C8 & $\mathrm{S} / \mathrm{L}$ & SD & 1063 & 668 & NEGATIVO & NEGATIVO \\
\hline F10 & SD & NEGATIVO & 179 & 107 & NEGATIVO & NEGATIVO \\
\hline 08 & SD & NEGATIVO & 174 & 111 & NEGATIVO & NEGATIVO \\
\hline O9 & SD & NEGATIVO & 136 & 156 & NEGATIVO & NEGATIVO \\
\hline J16 & SD & NEGATIVO & 107 & 179 & NEGATIVO & NEGATIVO \\
\hline K10 & SD & SD & 118 & 139 & NEGATIVO & NEGATIVO \\
\hline G10 & SD & SD & 158 & 110 & NEGATIVO & NEGATIVO \\
\hline H11 & SD & NEGATIVO & 105 & 103 & NEGATIVO & NEGATIVO \\
\hline D30 & SD & NEGATIVO & SD & $\mathrm{SD}$ & NEGATIVO & NEGATIVO \\
\hline D31 & SD & NEGATIVO & SD & $\mathrm{SD}$ & NEGATIVO & NEGATIVO \\
\hline H12 & SD & NEGATIVO & SD & SD & NEGATIVO & NEGATIVO \\
\hline Q33 & SD & NEGATIVO & SD & $\mathrm{SD}$ & NEGATIVO & NEGATIVO \\
\hline P18 & SD & NEGATIVO & SD & $\mathrm{SD}$ & NEGATIVO & NEGATIVO \\
\hline P19 & SD & NEGATIVO & SD & SD & NEGATIVO & NEGATIVO \\
\hline P20 & SD & NEGATIVO & SD & SD & NEGATIVO & NEGATIVO \\
\hline R13 & SD & NEGATIVO & SD & $\mathrm{SD}$ & NEGATIVO & NEGATIVO \\
\hline E11 & SD & NEGATIVO & SD & SD & POSITIVO & POSITIVO \\
\hline E12 & SD & NEGATIVO & SD & $\mathrm{SD}$ & NEGATIVO & NEGATIVO \\
\hline G11 & SD & SD & SD & SD & NEGATIVO & NEGATIVO \\
\hline G12 & SD & SD & SD & $\mathrm{SD}$ & NEGATIVO & NEGATIVO \\
\hline G13 & SD & SD & SD & SD & NEGATIVO & NEGATIVO \\
\hline A12 & SD & NEGATIVO & SD & SD & NEGATIVO & NEGATIVO \\
\hline
\end{tabular}




\begin{tabular}{llcllll}
\hline $\mathbf{A 1 3}$ & SD & NEGATIVO & SD & SD & NEGATIVO & POSITIVO \\
\hline B13 & SD & NEGATIVO & SD & SD & NEGATIVO & NEGATIVO \\
F11 & SD & NEGATIVO & SD & SD & NEGATIVO & NEGATIVO \\
M16 & SD & SD & SD & SD & NEGATIVO & NEGATIVO \\
M17 & SD & SD & SD & SD & NEGATIVO & NEGATIVO \\
K11 & SD & NEGATIVO & SD & SD & NEGATIVO & NEGATIVO \\
$\mathbf{J 1 7}$ & SD & NEGATIVO & SD & SD & NEGATIVO & NEGATIVO \\
$\mathbf{J 1 8}$ & SD & POSITIVO & SD & SD & POSITIVO & POSITIVO \\
$\mathbf{G 1 4}$ & SD & NEGATIVO & SD & SD & NEGATIVO & NEGATIVO \\
\hline
\end{tabular}

Tabla IV.26. Relación de todos los animales incluidos en el estudio, así como los resultados de todas las pruebas diagnósticas realizadas. Identif.: Identificación del animal. Loc. De la Lesión.: Localización anatómica de la lesión. IDR: prueba de intradermorreacción; P: Pulmón; GLC: Ganglio linfático de la cabeza (retrofaríngeos); GLP: Ganglio linfático del pulmón (mediastínicos); H: Hígado; GLM: Ganglio linfático mesentérico; S/L: Sin lesiones; SD: Sin datos (prueba no realizada). 


\section{DISCUSIÓN}

"La mayor parte de los fracasos nos vienen por querer adelantar la hora de los éxitos"

Amado Nervo (1870-1919) 
La tuberculosis y paratuberculosis son enfermedades crónicas de gran importancia en los rumiantes domésticos. La tuberculosis bovina es una de las enfermedades que más recursos económicos ha consumido debido las extensas campañas de control y erradicación que se han llevado a cabo en numerosos países, por sus implicaciones zoonósicas. En México sigue siendo una de las zoonosis de mayor prevalencia.

La paratuberculosis, por su impacto productivo en el ganado vacuno y posible relación con la enfermedad de Crohn es también uno de los procesos más importantes dentro de las infecciones lentas y de interés por su posible potencial zoonósico. En México la situación sobre la prevalencia de esta enfermedad en bovinos es desconocida, pero se ha comunicado que es una causa de pérdidas económicas en algunos estados [Miranda, 2005]. El trabajo presentado en esta tesis constituye la primera aportación sobre la incidencia de Map en bovinos sacrificados en matadero.

Manning y Collins (2001) mencionan que tanto la tuberculosis como la paratuberculosis son enfermedades que deben permanecer bajo vigilancia epidemiológica, ya que con la identificación de los animales infectados en cada explotación se puede evitar la diseminación de estos agentes. Los sistemas de vigilancia epidemiológica en mataderos poseen un valor indiscutible no sólo para detectar la presencia de tuberculosis bovina sino para mejorar las condiciones sanitarias de las explotaciones ganaderas y para una óptima comercialización de carnes y subproductos [Torres, 2010].

En el caso de la tuberculosis, la inspección post mortem es de gran importancia, al permitir la detección de un mayor porcentaje de animales positivos durante las campañas de saneamiento [García Castro, 2007], de forma que en países como EEUU se considera el método primario de detección de bovinos con tuberculosis [Whipple et al., 1996].

Por ello, en este trabajo nos hemos planteado como principal objetivo estimar la efectividad de diferentes pruebas diagnósticas (ELISA, histopatología, PCR) de forma complementaria a la inspección post mortem, para el diagnóstico rápido de micobacteriosis ( $M$. bovis, Map y Maa) en bovinos de matadero así como la valoración de las posibles reacciones cruzadas entre las mismas.

En nuestro estudio la prevalencia de tuberculosis observada en bovinos mayores de dos años fue del 8,99\%, superior a la señalada en las Campañas de Saneamiento en nuestro país (0,5\%) [SAGARPA, 2013]. Estos datos sugieren que la prevalencia de la tuberculosis en el estado de Nayarit es superior a la del resto del país; sin embargo, hay que tener en cuenta que en este estudio no se han estudiado todos los animales analizados en las campañas de erradicación de la tuberculosis, sino que fueron elegidos al azar en dos periodos de los años 2011 y 2012. 
Como ya se ha indicado, la valoración lesional post mortem tiene una gran importancia en la detección de animales infectados por M. bovis. García Castro (2007) cita una prevalencia del 3,1\% de tuberculosis en un estudio de matadero, basándose en la detección de lesiones frente al 1\% del resultado de las campañas de saneamiento, por lo que concluye que la inspección de matadero sería altamente eficaz en la detección de casos de tuberculosis negativos mediante la prueba de intradermorreacción en las Campañas de Saneamiento, siendo un complemento de las mismas. En nuestro estudio, si consideramos los animales donde se aplicaron ambas pruebas, encontramos que 30 (58,8\%) de los 51 que fueron negativos a IDR presentaron lesiones que si bien no se puede aseverar que fueran debidas a la infección por $M$. bovis, sugieren una mayor sensibilidad del estudio lesional, con la técnica de muestreo elegida, para la detección de animales infectados.

Aunque en nuestro estudio solo se observaron lesiones macroscópicas en dos bovinos (ganglios linfáticos mediastínicos y mesentéricos), en un 56,47\% de los estudiados mediante histopatología se observaron lesiones granulomatosas leves de carácter focal mayoritariamente. Respecto a su especificidad, por su morfología se podrían considerar como dudosas. Se ha sugerido que pudieran ser granulomas formados por lo que se han denominado "macrófagos basura”, agrupados para captar cuerpos extraños que pudieran haber llegado al nódulo linfático desde el intestino o las vías respiratorias [Huda y Jensen, 2003; González et al., 2005]. Sin embargo, algunas lesiones similares se han observado en infecciones iniciales o latentes por Map [Pérez et al., 1996; Moreno et al., 2008] y Maa. [Chávez et al., 2004]. Atendiendo a su extensión se clasificaron en tres tipos: 1A (51,42\%), tipo 1B (37,14\%) y el tipo 1C (25,71\%), siendo todas ellas morfológicamente similares.

Cuando se estudió la presencia de micobacterias en dichas lesiones, los resultados obtenidos mediante la tinción de Ziehl-Neelsen en los ganglios linfáticos de 5 animales fueron negativos, coincidiendo con lo observado por otros autores en granulomas de estas características producidos por Map [Pérez et al., 1996; Balseiro et al. 2003; González et al. 2005; Montero et al., 2006] o Maa. [Chávez et al., 2004]. En un trabajo realizado en un total de 6.972 bovinos menores de 1 año de edad sin clínica ni lesiones macroscópicas se pudieron observar lesiones en ganglios linfáticos semejantes a las descritas por nosotros en el 2,09\%, todas ellas negativas mediante Ziehl-Neelsen siendo el 35\% positivos en PCR a Map. [Moreno et al., 2008], hecho que coincide parcialmente con nuestros resultados. Así mismo, Magnano et al. (2010) realizaron un trabajo donde compararon técnicas diagnósticas de tuberculosis porcina en dos establecimientos de cría confinada en Argentina, obteniendo resultados negativos en el 100\% de las muestras mediante la tinción de Z-N, si bien los animales mostraban lesiones granulomatosas en ganglios linfáticos. En este trabajo, como en el nuestro, no se observó la presencia de bacilos ácido-alcohol resistentes. 
Actualmente el diagnóstico etiológico de muchas enfermedades se ha enriquecido con el desarrollo de la técnica de la PCR. Para la instrumentación de esta prueba, se puede partir de cualquier muestra biológica, habiéndose demostrado una elevada sensibilidad y especificidad en el diagnóstico de las micobacteriosis tanto en humanos como en bovinos [Cousins, et al., 1992; Wards et al., 1995; Miller et al., 1999, 2000, 2002]. La aplicación de la PCR en tejidos incluidos en parafina con lesiones previamente valoradas se ha llevado ya a cabo en el diagnóstico de micobacteriosis [Jaimes et al., 2008], habiendo demostrado su utilidad. Como mencionan Martínez-Vidal (2008), López-Garrido (2008) y Miller et al. (2002), a diferencia del cultivo bacteriológico, con la PCR se llegan a obtener resultados satisfactorios con pequeñas cantidades de bacilos presentes en la muestra, mientras que para obtener resultados en un cultivo es necesario un mayor número de bacilos y además éstos tienen que ser viables. Talbot et al., (1997) y Chávez et al., (2004), en México han llegado a tipificar diferentes cepas de una misma especie de micobacteria mediante técnicas de biología molecular. También Velarde et al. (2007) recomiendan el uso de técnicas moleculares, principalmente la PCR, y hacen referencia a que en comparación con las pruebas de tuberculina, cultivo e histopatológicas, la PCR demuestra mayor grado de confiabilidad.

Tomando como base lo señalado por Portilla (2007) cuando asegura que la PCR, como prueba complementaria a la histopatología y al aislamiento, permitiría establecer una metodología más rápida para el diagnóstico en animales infectados, en este estudio hemos llevado a cabo técnicas de PCR fundamentalmente frente al complejo M. tuberculosis y Map en muestras de tejido en las que también se llevó a cabo una valoración lesional, aunque como se ha explicado en el capítulo de material y métodos, con serias limitaciones debido al deficiente procesado de algunas muestras que impidió su examen microscópico.

En este sentido, debe tenerse en cuenta que el procesado de las muestras en cuanto a su fijación en formol e inclusión en parafina condiciona de una manera determinante la futura amplificación del ADN micobacteriano [Miller et al., 2002], hecho a tener en cuenta en este estudio donde la fijación en formol duró aproximadamente una semana. Por otra parte, la existencia de un número reducido de micobacterias en las lesiones también influyen en una menor probabilidad de obtener un resultado positivo a PCR s [Ramírez et al., 2006; Balseiro et al., 2008].

Los resultados obtenidos en este estudio indican que un 23,07\% de los bovinos con lesiones granulomatosas fue positivo a la PCR en secciones histológicas frente a $M$. bovis (complejo M. tuberculosis), porcentaje similar a los que no presentaron lesiones. Este hecho vendría a corroborar el carácter "dudoso" o no especifico de las lesiones observadas en lo que respecta a su etiología micobacteriana. Nuestros resultados son inferiores al 93\% de positividad observado por Miller et al. (2002) en casos con lesiones más evidentes y características de tuberculosis. Así mismo, Morales et al. (2005) obtuvieron resultados 
positivos en el 45,6\% de las muestras sin lesiones microscópicas en el pulmón y nódulos linfáticos pulmonares y en el 60,6\% de bovinos con lesiones histopatológicas sugestivas de tuberculosis. Al igual que en la PCR para el Complejo M. tuberculosis, la positividad a Map fue más baja e igual en animales con lesiones que sin lesiones histopatológicas. En el trabajo realizado por Moreno et al., (2008) se detectó Map mediante la PCR en secciones histológicas en un 35\% de casos con lesiones "focales-dudosas" similares a las observadas por nosotros, y en el 100\% de las muestras de animales con lesiones multifocales y difusas. De acuerdo a estos resultados, no se puede afirmar que dichas lesiones sean debidas a una infección por $M$. bovis o Map, si bien tampoco puede descartarse por completo. Debe tenerse en cuenta que en otros estudios [Pérez et al., 1996; González et al., 2005] se ha podido incluso aislar Map mediante cultivo bacteriológico a partir de muestras de tejido que mostraban lesiones semejantes en ovinos y bovinos, lo que apoyaría su etiología micobacteriana.

Por otra parte, el hecho de que se hayan descrito también lesiones granulomatosas debidas a Maa similares a las encontradas por nosotros [Chávez et al., 1994] motivó el llevar a cabo la prueba de PCR frente a esta micobacteria en algunas muestras de tejido que presentaban lesiones. De esta manera, en 15 muestras seleccionadas de 14 animales con lesiones microscópicas, 14 (13 animales) fueron positivas a PCR frente a Maa, mientras que solo dos lo fueron a Complejo M. tuberculosis (M. bovis) y todas negativas a Map, hecho que sugiere la participación de Maa en la génesis de dichas lesiones, así como la existencia de infecciones mixtas. Este hecho creemos que tiene gran relevancia y la existencia de bovinos infectados por Maa debería ser considerado en futuros estudios para valorar su posible implicación en las campañas de erradicación de la tuberculosis. Incluso debe considerarse que es posible que el número de infecciones mixtas sea más elevado que el encontrado en este estudio, ya que el número de muestras analizadas ha sido bajo y además se han utilizado protocolos diferentes de extracción, ya que mientras frente a $M$. bovis y Map, consistió en la congelación/descongelación descrito por Garrido (2001), en las 15 muestras seleccionadas se valoró la presencia de ADN de Maa, Map y Complejo M. tuberculosis empleando el kit comercial Speedtools Tissue DNA, además de emplear secciones histológicas con lesiones y no realizar "pool” de muestras como en el caso de las dos últimas (Map y M. bovis).

Con respecto a la distribución de las lesiones, en los ganglios linfáticos de la cabeza se identificaron en el $28,57 \%$ de las muestras, en los ganglios linfáticos mediastínicos en el 11,42\%y en los mesentéricos en el 34,28\%. García Castro (2007) observó un 14,6\% de lesiones macroscópicas características de tuberculosis en los ganglios linfáticos retrofaríngeos similar a lo obtenido por Corner et al. (1990) $(29,4 \%)$ en la misma localización y porcentaje muy inferior al 4,9\% aportado por Cuezva Samaniego y de la Encina (1958). Si bien, estos autores como ya hemos mencionado, se basan principalmente en lesiones observadas macroscópicamente y claramente compatibles con tuberculosis. 
El examen post mortem de ganglios linfáticos y pulmones en los bovinos en matadero, apoyado con estudios histológicos y bacteriológicos, se considera de gran importancia, para la identificación de animales infectados dentro de los programas de erradicación de la tuberculosis [Collins, 2006], debiendo tenerse en cuenta que las lesiones que pueden variar dependiendo del tiempo de infección, la susceptibilidad del huésped y la dosis infectiva [O’Reilly y Daborn, 1995; Pollock et al., 2006]. Como se ha señalado, en nuestro estudio no se observaron lesiones características compatibles con tuberculosis, a excepción de 2 animales que tenían lesiones macroscópicas (ganglios linfáticos mediastínicos y mesentéricos) que se correspondían con focos inflamatorios piogranulomatosos en el estudio microscópico. En uno de ellos, se detectó ADN tanto de M. bovis como a Maa, mediante PCR, pudiendo estar estos agentes implicados en su génesis. Además, también se detectaron microscópicamente lesiones “focales-dudosas” en el mismo ganglio linfático, no pudiendo llevarse a cabo un diagnóstico etiológico certero de dichas lesiones.

Como ya se ha mencionado, en 36 (56,45\%) animales se encontraron lesiones microscópicas, mientras que sólo 2 de ellos mostraron cambios visibles macroscópicamente, demostrando que la histopatología es un método diagnóstico eficaz para detectar y caracterizar lesiones en las micobacteriosis [Pérez et al., 1996; EstradaChávez et al. 2004; Balseiro et al., 2008].

Cuando se emplearon las técnicas de ELISA indirecto, en nuestro estudio el 9,68\% de los animales fue positivo en ELISA frente a Map y el 18,12\% en ELISA frente a $M$. bovis. Es de destacar que 15 animales fueron positivos a ambas pruebas, y de ellos, en tres se detectó $M$. bovis en los tejidos, y en otros tres tanto M. bovis como Map; en el resto, no se pudo poner en evidencia la existencia de infección micobacteriana. Esto, confirma la existencia de infecciones mixtas por diferentes especies de micobacterias en el mismo animal, tal y como ya se ha señalado en bovinos [Yokomiso et al., 1983; González, 2003]. Por otra parte, tampoco se descarta que la positividad al ELISA indirecto, superior a la obtenida con otras pruebas como la IDR, pudiera estar asociada con infecciones por otras micobacterias aviares, ya que comparten antígenos y los empleados en estas técnicas no son completamente específicos [Van der Giessen et al., 1994; Rastogi et al., 2001]. El elevado grado de concordancia entre ambas pruebas diagnósticas encontrado indica que se debe tener un especial cuidado en la interpretación de estas técnicas para discriminar animales infectados por estas micobacterias, ya que su especificidad no sería demasiado elevada debido a la existencia de reacciones cruzadas, limitaciones de la técnica o los antígenos empleados.

Generalmente, la detección de anticuerpos séricos en el test ELISA se relaciona con animales que presentaron lesiones avanzadas o con una elevada presencia de bacilos en la muestra, tal y como han descrito otros autores, tanto en casos de tuberculosis como de 
paratuberculosis [Gutiérrez et al., 1998; Pérez et al., 1997; Balseiro et al., 2008]. En nuestro estudio, en principio, no se observaron este tipo de lesiones sino solamente infiltrados granulomatosos focales por lo que, como ya se ha señalado, debería considerarse la posible existencia de reacciones cruzadas de los test serológicos frente a Map y Maa. De todas formas, tampoco puede descartarse del todo que no existieran animales con formas lesiones más difusas, clásicamente asociadas a respuestas serológicas, debido a las dificultades planteadas en el procesado de las muestras que impidieron su correcta valoración, tanto en relación con el número de animales examinados como con la calidad de las muestras estudiadas.

Igualmente, llama la atención la inexistencia de diferencias en el porcentaje de animales positivos en relación con su edad, ya que, siguiendo el modelo clásico de patogenia de las micobacteriosis, tanto en paratuberculosis como tuberculosis, el número de individuos con presencia de anticuerpos humorales se asocia a fases más avanzadas que aparecen con más frecuencia en animales mayores de 2 años [Ramírez et al., 2011]. En este sentido, en un estudio llevado a cabo en dos explotaciones de vacuno lechero en España, el porcentaje de animales positivos a la misma técnica de ELISA indirecto aquí empleada se incrementaba significativamente con la edad [Mohamed Anciones et al., 2013], en contradicción con lo encontrado en este estudio. Debe tenerse en cuenta que en el estudio referido se estudiaba toda la población de dos explotaciones con casos clínicos de paratuberculosis, mientras que en este trabajo son animales procedentes de diferentes granjas y localidades, sin conocer si existían casos de paratuberculosis o tuberculosis en ellas. Además, debe tenerse en cuenta el papel que pudiera jugar Maa, infección comprobada como presente en algunos de estos animales, en la positividad encontrada, teniendo en cuenta que las infecciones por este grupo de micobacterias raramente llegan a ocasionar cuadros clínicos graves [Chávez et al., 1994] y por lo tanto es posible que no se produzca en ellas la transición hacia respuestas inmunológicas humorales en relación con la edad que se observa en tuberculosis o paratuberculosis.

Tomando como referencia la prueba de intradermorreacción, la prueba ELISA frente a $M$. bovis presentó una sensibilidad del 32\% y una especificidad del 15,32\% observándose una concordancia débil del 0,121, lo que sugiere que ambas técnicas deberían ser consideradas como complementarias y no sustitutivas unas de otras. Con la PCR como prueba de referencia, en el test ELISA frente a $M$. bovis se obtuvo una sensibilidad del 11,53\% y una especificidad del 97,54\%, y en el test ELISA de Map una sensibilidad y especificidad del 4\% y 98,70\% respectivamente. Según estos datos ambas pruebas de ELISA parecen mostrar una buena especificidad, si bien debería haberse contemplado también el papel de Maa en estas respuestas. Sería necesaria una buena prueba de referencia "gold standard" para evaluar estas técnicas, siendo quizás la combinación de varias como el cultivo, histopatología y PCR la más adecuada. Respecto a la baja sensibilidad de la técnica de ELISA (tb o ptb) con respecto a la PCR podría estar 
relacionada con el tipo de infección observada, caracterizada por lesiones microscópicas focales normalmente no asociadas a respuestas serológicas evidentes, o presentar una etiología diferente.

Los valores del índice Kappa de concordancia entre la PCR con la prueba ELISA frente a $M$. bovis y la presencia de lesiones histopatológicas, fueron de k=0,088 y k=-0,009 respectivamente, mientras que para la PCR con la prueba ELISA frente a Map y la presencia de lesiones, los valores fueron de $\mathrm{k}=0,067 \mathrm{y} \mathrm{k}=0,006$. En todos los casos se trata de índices de concordancia muy bajos y notablemente inferiores en comparación con los reportados por Estrada-Chávez et al. (2004) que obtuvieron unos valores de k=0,44 en relación a la prueba de la PCR y la presencia de lesiones histopatológicas compatibles con tuberculosis. Las dificultades en la valoración de lesiones en nuestro estudio y el papel que pueda jugar Maa, no contemplado en el trabajo reseñado, pudieran explicar estas diferencias.

En el análisis comparativo de pruebas diagnósticas para tuberculosis llevadas a cabo en este estudio, de las 275 muestras evaluadas, la prueba de IDR, permitió detectar un 2,93\% de animales positivos, a diferencia de la prueba ELISA que detectó un 16,84\%. [Estévez-Denaives et al., 2007]. Además de considerar la procedencia múltiple de los animales, que dificultaría la aplicación del esquema patogénico de las micobacteriosis, debe considerarse que pudieran haber existido fallos en la realización de la prueba de IDR, tanto en su ejecución como en su interpretación, al considerarse incrementos de grosor cutáneos de $5 \mathrm{~mm}$ como positivos; posiblemente si se hubiera tomado como referencia un incremento de $4 \mathrm{~mm}$, el número de animales positivos hubiera sido más elevado. Por otra parte, tampoco debe descartarse la existencia de reacciones cruzadas con otras micobacterias ya que, como se ha señalado [Paolicchi et al., 2003], comparten antígenos comunes. Finalmente, a pesar de no haber encontrado evidencias lesionales de ello, tampoco puede descartarse que algunos de esos animales negativos a IDR fueran anérgicos a esta prueba, ya que aunque la IDR es considerada como un método eficaz para determinar el estado sanitario de bovinos infectados con M. bovis [O’Reilly y Daborn, 1995; Garro et al. 2011], el estado inmunitario de los animales interfiere notablemente en dicha respuesta al no detectar la infección en etapas iniciales o estadios anérgicos [O’Reilly y Daborn, 1995; Dante et al., 2007].

Respecto a la presencia de la infección tuberculosa en los diferentes municipios, si bien mediante el ELISA se detectaron animales positivos en todos los, en el caso de la IDR, no se detectaron animales positivos en uno de ellos (grupo G). Sin embargo, debe tenerse en cuenta que las diferencias no fueron estadísticamente significativas cuando se analizó la positividad a ambas pruebas según el municipio. Así mismo, se observó una escasa relación entre ambas pruebas. 
Los criterios diagnósticos utilizados en nuestro estudio, basados en la inspección post-mortem, histopatología, así como en las técnicas de ELISA y la PCR, han permitido confirmar mediante la presencia de infecciones debidas a Map, M. bovis y de Maa en bovinos sacrificados en matadero del estado de Nayarit. En la actualidad se desconoce la prevalencia de la infección por Map en México, y aún se tienen menos datos de la importancia que pudiera tener la infección por Maa en los bovinos del país. En cualquier caso, la positividad frente a micobacterias del grupo $M$. avium supone un impedimento para el comercio de ganado [Estévez-Denaives et al., 2007] que, según nuestro estudio tiene una notable relevancia y debe ser objeto de futuros trabajos. 


\section{VIII.CONCLUSIONES}

"La verdadera educación consiste en obtener lo mejor de uno mismo. ¿Qué otro libro se puede estudiar mejor que el de la humanidad? Mahatma Gandhi (1869-1948) 
1. Se confirmó la presencia de infección tuberculosa en animales negativos a la prueba de intradermorreacción simple, en el Estado de Nayarit, México, utilizando la técnica de la PCR y el test de ELISA. Así mismo, también se detectó la presencia de ADN de Map y Maa en muestras de tejido. Del primero no se tiene conocimiento de la prevalencia en Nayarit y del segundo no existen referencias conocidas de su presencia en ganado bovino en México, siendo la detección de ambas de gran importancia epidemiológica.

2. Este estudio es el primer reporte epidemiológico de la infección por Map en el estado de Nayarit, México. Es necesario que se realicen estudios en diferentes áreas de México para descartar o confirmar la presencia de Map, ya que no hay la suficiente información con respecto a bovinos.

3. Los resultados obtenidos por la PCR e histopatología indican que las técnicas cumplen con los requisitos necesarios para proporcionar un diagnóstico eficiente, en tiempo y costo, para ser consideradas como herramientas complementarias de la IDR en las Campañas de control de tuberculosis bovina y para evidenciar infecciones por otras micobacterias durante las mismas.

4. La prevalencia de la tuberculosis en animales sacrificados en matadero del estado de Nayarit osciló entre el 7,28\% y el 18,12\% de los individuos analizados, según la técnica empleada. Respecto a paratuberculosis, el porcentaje de positivos estaba entre el 4 y el $9,9 \%$ de los bovinos.

5. La constatación de la presencia de infecciones por micobacterias del complejo $M$. tuberculosis (M. bovis) y del complejo M. avium (Maa y Map) en bovinos de la misma región, incluso en el mismo animal, debería tenerse en consideración en el momento de planificar y realizar las campañas de saneamiento de la tuberculosis en México y en la valoración de los resultados. 


\section{RESUMEN}

"La educación es el pasaporte hacia el futuro, el mañana, pertenece a aquellos que se preparan para él, en el día de hoy" Malcolm X (1925-1965) 
La tuberculosis y la paratuberculosis son las dos enfermedades producidas por micobacterias de mayor importancia en el ganado bovino en todo el mundo. En México, frente a la primera se llevan a cabo campañas de control y erradicación desde hace varios años, mientras que respecto a la paratuberculosis, no existen estudios rigurosos que ofrezcan datos acerca de su prevalencia o importancia en la ganadería bovina de México. Teniendo en cuenta la importancia que la inspección post mortem tiene en el diagnóstico de esta enfermedades y especialmente en la confirmación de la infección tuberculosa en los animales positivos en las campañas de saneamiento, en este trabajo se ha llevado a cabo un estudio en animales sacrificados en matadero en el estado de Nayarit (México) tras haberse realizado en ellos la prueba de intradermorreacción simple (IDR) para el diagnóstico de tuberculosis, con el objetivo general de conocer la prevalencia de tuberculosis y paratuberculosis en bovinos sacrificados en matadero y de valorar la eficacia de diferentes técnicas diagnósticas para su detección. En concreto, se plantea evaluar la eficacia del diagnóstico post mortem mediante la evaluación histológica de muestras de tejido definidas, y comparar el comportamiento de diferentes técnicas de diagnóstico inmunológico (ELISA indirecto frente a tuberculosis o paratuberculosis, IDR), de detección de ADN micobacteriano (frente al complejo M. bovis, M. avium paratuberculosis (Map) o M. avium avium (Maa) y la detección de lesiones mediantes técnicas histopatológicas.

Para ello se ha realizado un estudio anatomopatológico en 343 animales sacrificados en matadero, de los cuales 289 bovinos eran mayores de 2 años y 54 menores de 2 años de edad, procedentes de los 20 municipios del Estado de Nayarit, México. En todos ellos, se llevó a cabo la observación de todos los órganos, especialmente de pulmón y nódulos linfáticos relacionados, nódulos linfáticos de la cabeza, intestino y nódulos linfáticos mesentéricos.

En todos los casos $(n=343)$ se tomaron muestras de ganglios linfáticos retrofaríngeos, mediastínicos y pulmón para la valoración de lesiones tuberculosas, y de válvula ileocecal y ganglios linfáticos mesentéricos para estudiar lesiones asociadas a la infección por Map. Debido a un mal procesado de las muestras, únicamente se pudo llevar a cabo la valoración lesional en 62 de estos animales. En 289 animales se había llevado a cabo la valoración de la respuesta inmune celular frente a tuberculosis mediante la prueba de IDR, empleando como antígeno PPD bovina. Esta técnica se realizó por personal capacitado por el Comité Estatal para el Fomento y Protección Pecuaria de Nayarit, S.C. En 320 bovinos se valoró la respuesta inmune humoral mediante una técnica de ELISA indirecto frente a tuberculosis y paratuberculosis, empleando como antígenos PPD bovina o el antígeno protoplasmático PPA-3 respectivamente. En 275 animales se realizaron pruebas moleculares (PCR) a partir de tejido embebido en parafina, para la identificación de la secuencia de inserción IS6110 específica de M. bovis y la secuencia de inserción IS900 específica de Map. En 14 animales, seleccionados por la presencia de lesiones, se realizó la PCR para la detección simultánea de Maa, Map y M. bovis. 
De los 289 animales a los que se les aplico IDR $(8,99 \%)$ se consideraron como positivos. Los animales reaccionantes aparecieron en 14 de los 20 municipios estudiados, oscilando la positividad entre el 5,26 y el 28,57\%. En cuanto al ELISA frente a M. bovis y Map de las 320 muestras se confirmó el diagnostico positivo en el 18,12\% y el 9,99\% respectivamente. Se encontraron animales reaccionantes en todos los municipios estudiados, pero únicamente en 8 y 6 respectivamente superaban el $25 \%$ de los reaccionantes en el ELISA de tuberculosis y paratuberculosis respectivamente, coincidiendo los valores elevados únicamente en un municipio. No se observaron diferencias estadísticamente significativas en el porcentaje de positividad entre animales menores y mayores de dos años. Las lesiones macroscópicas solo pudieron observarse en 2 de los 343 animales estudiados y consistieron en focos miliares de necrosis caseosa en nódulos linfáticos respiratorios y de la cabeza. En 35 (56,45\%) de los 62 animales en los que se pudieron estudiar microscópicamente los tejidos, se encontraron lesiones granulomatosas, especialmente en los nódulos linfáticos.

Atendiendo a su extensión y características morfológicas, se consideraron en todos los casos como lesiones granulomatosas focales, que se clasificaron en tres categorías: 1A: escaso número de granulomas de pequeño tamaño cuyos macrófagos contenían abundante pigmento ceroide; 1B: granulomas de mayor tamaño con distribución multifocal; 1C: granulomas abundantes, que confluían y llegaban a ocupar amplias zonas de la región cortical. Estas lesiones fueron más abundantes en los ganglios linfáticos de la cabeza y mesentéricos. La prueba de PCR se llevó a cabo en 275 animales resultando positiva para la secuencia de inserción IS6110 en 20 (7,28\%) y en $11(4 \%)$ en la secuencia de inserción IS900 de Map. Respecto a Maa, 13 de las 14 muestras analizadas con lesiones granulomatosas fueron positivas. De ellas, solamente dos habían sido también positivas para M. bovis. Tomando como referencia la prueba de intradermorreacción, la prueba ELISA frente a $M$. bovis ofreció valores de sensibilidad y especificidad del $47,05 \%$ y 93,83\% respectivamente, y un valor de kappa del 0,121, significando una concordancia escasa. Cuando se tomó como referencia la PCR, la sensibilidad y especificidad de la técnica IDR fue del 27,27\% y 91,7\% respectivamente, y de ELISA frente a tuberculosis de $24,07 \%$ y $97,47 \%$. Respecto al ELISA de paratuberculosis, su sensibilidad fue del 13,33\% y la especificidad del 98,19\% respecto al PCR de Map. En todos los casos, la concordancia entre técnicas fue débil.

Según estos resultados, la prevalencia de la tuberculosis en animales sacrificados en matadero del estado de Nayarit osciló entre el 7,28\% y el 18,12\% de los individuos analizados, según la técnica empleada. Respecto a paratuberculosis, el porcentaje de positivos entre el 4 y el 9,9\%, siendo el primer estudio epidemiológico de esta enfermedad llevado en Nayarit. En este trabajo, se ha demostrado la presencia de Maa asociada a lesiones granulomatosas en vacas de este estudio. Las técnicas de PCR e histopatología indican que ambos métodos cumplen con los requisitos necesarios para proporcionar un 
diagnóstico eficiente, en tiempo y costo, para ser consideradas como herramientas complementarias de la IDR en las Campañas de control de tuberculosis bovina y para evidenciar infecciones por otras micobacterias durante las mismas. El hecho de que hayan aparecido animales con infecciones por distintas micobacterias debe tenerse en cuenta a la hora de interpretar los resultados de las campañas de saneamiento de tuberculosis. 


\section{SUMMARY}

"Donde hay educación no hay distinción de clases"

Confucio (551 AC- 478) 
Tuberculosis and paratuberculosis are two diseases produced by micobacteria of major importance in cattle worldwide. In México, control an eradication campaign was carried out on tuberculosis over the last few years, while with regard to paratuberculosas, no rigorous studies exist which offer data on the prevalence or importance in cattle in México. Taking into account the importance that post mortem inspection has on the diagnosis of these diseases and when confirming the tubercles infection in positive animals in the health campaign, a study into animals sacrificed at the state abattoir in the state of Nayarit (México) was carried out after performing skin test (IDR) on the animals with the main objective of knowing tuberculosis and paratuberculosas prevalence in cattle sacrificed at the abattoir and of assessing the effectiveness of different diagnostic techniques for their detection. It was specifically proposed to evaluate the efficiency of the post mortem diagnosis using the histological evaluation of defined tissue samples and to compare the behavior of different indirect diagnostical immunological techniques (ELISA to use against tuberculosis or paratuberculosas, IDR) for the detection of mycobacterial DNA (specially complex M. bovis, M. avium paratuberculosis (Map) or M. avium and the detection or lesions using histopatological techniques.

For this an anatomopathologic study was carried out on 343 animals sacrificed at the abattoir, 289 of which were more than 2 years old and 54 were less than 2 years old, all coming from municipalities in the organs, especially lung and related lymphatic nodules, lymphatic nodules of the head, intestine and mesenteric lymph nodes.

In all cases $(n=343)$ samples were taken of retropharyngeal lymph nodes and lung to assess the tubercles lesions and the ileocecal valve and mesenteric lymph nodes to study the lesions related to the infection by Map. Due to bad sample processing only the lesion assessment of 62 of these animals could be carried out. The assessment of the immune cellular response, specially tuberculosis using the IDR test using bovine PPD as an antigen was carried out. This techniques was performed by capable persons in Comité Estatal para el Fomento y Protección Pecuaria de Nayarit, S.C. In 320 cattle the humoral immune response using the ELISA indirect techniques was assessed specially tuberculosis and paratuberculosis, using PPD bovine as antigens or protoplasmatic antigen PPA-3, respectively. Molecular tests (PCR) were performed on 275 animals from tissue inserted in paraffin in order to identify the insertion sequence IS6110, specific of $M$. bovis and insertion sequence IS 900 specific of Map. In 14 animals, selected because of the presence of lesions, PCR for the simultaneous detection of Maa, Map and M. bovis was carred out.

IDR (8.99\%), which were considered as positive was applied to 289 animals. The animals which reacted appeared in 14 of the 20 state municipalities, the positive animals varied between 5.26 and 28.57\%. With regard to ELISA, specially M. bovis and Map of the 320 samples, a positive diagnosis of between $18.12 \%$ and $9.99 \%$ was confirmed. Animals which reacted were found in all the municipalities studied but only 8 and 6 respectively 
exceeded $25 \%$ of those which reacted in ELISA of tuberculosis and paratuberculosis respectively, with only high values coinciding in one municipality. No significant statistical differences were observed in the percentage of positive animals younger or older than two years. The macroscopic lesions could only be observed in 2 of the 342 animals studied and they consisted of milliard focuses of caseosus necrosis in respiratory lymphatic nodules and of the head. In 35 (56.45\%) ot the 62 animals, where the tissues could be microscopically studied, granulomatous lesions were found in the lymphatic nodules. Paying attention to their extension and morphological characteristics, they were, in all cases considered as granulomatous focal lesions which were classified into three categories: 1A: Scarce number of small-sized granulomas whose macrophage contain abundant ceroide pigments; 1B: large-sized granulomas with a multi-focal distribution; 1C: abundant granulomas which join together and occupy large areas in the cortical region. These lesions were more abundant in the lymphatic nodes of the head and mesenteric. The PCR tests was performed on 275 animals being positive for the IS6110 insertion sequence in 20 (7.28\%) and in 11 (4\%) in the IS900 insertion sequence of Map. With regard to Maa, 13 of the 14 samples analyzed with granulomatous lesions were positive, only two of the were also positive for M. bovis. Taking the skin tests as a reference, the ELISA tests especially M. bovis showed sensitivity and specificity values of $47.05 \%$ and $95.83 \%$ respectively, and a kappa value of 0.121 , signifying a scarce concordance. When PCR was taken as a reference, sensitivity and specificity of the IDR technique was $27.27 \%$ and $91.7 \%$ respectively and of ELISA especially tuberculosis of $24.07 \%$ and $97.47 \%$. With regard to ELISA of paratuberculosas, sensitivity was $13.33 \%$ and specificity $98.19 \%$ with regard to PCR of Map. Concordance between the techniques was weak in all cases.

According to the results, tuberculosis prevalence in the animals sacrificed at the abattoir in the State of Nayarit varied between $7.28 \%$ and $18.12 \%$ of the animals, depending on the techniques used. With regard to paratuberculosas, the percentage of the positive ones were between 4 and $9.9 \%$, this boing the first epidemiology study of this disease carried out in Nayarit. The presence of Maa associated to granulomatous lesions has been shown in this study. The PCR and histopatological techniques indicate that both methods comply with the requisites needed to give an efficient diagnosis, in time and cost, to be considered as complementary tools of IDR in cattle tuberculosis control campaign and to show infections by other micobacteria in the same campaigns. The fact that animals have appeared with infections by different micobacteria should be taken into account when interpreting the results of the health campaigns on tuberculosis. 


\section{BIBLIOGRAFÍA}

"Educación es lo que queda después de olvidar lo que se ha aprendido en la escuela" Albert Einstein (1879-1955) 
Ábalos, P. (2001). Actualidad en tuberculosis. En línea consultado: 20 de Marzo de 2011. www.tecnovet. uchile.cl/CDA/tecnovet_artículo.

Ábalos, P. y Retamal, P. (2004). Tuberculosis: ¿Una zoonosis re-emergente? Rev. Sci. Tech. Off. Int. Epiz. 23 (2): 583-594.

Abdala, A y Tarabla, H. (2007). Tuberculosis Bovina ¿A qué nos enfrentamos? Revista del Toráx. 8: 13-15.

Ácha, P.N. y Szyfres, B. (2001). Zoonosis y enfermedades transmisibles comunes al hombre y a los animales. $3^{a}$ edición. Vol. I. Bacteriosis y Micosis. Organización Panamericana de la Salud.

Acosta, B.; Real, F.; León, L.; Deniz, S.; Ferrer, O.; Rosario, I. y Ramírez, A. (2000). ELISA for antiMPB70: an option for the diagnosis of goat tuberculosis caused by Mycobacterium bovis. Aust. Vet. J. 78: 423-424.

Acosta-Salinas, R.; Estrada-Chávez, C. y Milián-Suazo, F. (2009). Tipificación de cepas de Mycobacterium bovis. Revisión. Téc. Рecu. Méx. 47: 389-412.

Adúriz, J.J.; Juste, R.A. y Saéz de Ócariz, C. (1994). An epidemiologic study of sheep paratuberculosis in the Basque Country of Spain: serology and productive data. En: Chiodini, R.J.; Collins, M.T. Bassey, E.O.E. Proc $4^{\text {th }}$ Int. Coll. PTBC. IAP. Providence. EEUU. pp: 19-26.

Adúriz, J.J.; Juste, R.A. y Cortabarría, N. (1995). Lack of mycobactin dependence of micobacteria isolated on Middlebrook 7H11 from clinical cases of ovine paatuberculosis. Vet. Microbiol. 45: 211-217.

Adúriz, G.; Juste, R.A.; Garrido, J.M. y Geijo, M.V. (2000). Epidemiología y control de la paratuberculosis bovina. En: Juste editor. Paratuberculosis. Bovis, Aula Veterinaria, 93: 63-93. España.

Alfaro, C.; De Rojo, M.; Clavijo, A. y Valle, A. (2006). Caracterización de la Paratuberculosis bovina en ganado doble propósito de los llanos de Monagas, Venezuela. Zootecnia Trop. 24: 321-332.

Allen, W.M.; Berrett, S. y Patterson, D.S. (1974). A biochemical study of experimental Johne's disease I. plasma protein leakage into the intestine of sheep. J. Comp. Pathol. 84: 381-384.

Aller, B.; Fernández Diez, M. y Escudero Diez, A. (1973). Paratuberculosis ovina. Supl. Cient. Bol. Inf. Consejo Gral. Col. Vet. España. 196: 11-18.

Amadori, M.; Lyashchenko, K.P.; Gennaro, M.L.; Pollock, J.M. y Zerbini, I. (2002). Use of recombinant proteins in antibody tests for bovine tuberculosis. Vet. Microbiol. 85: 379-389.

Ando, M. y Dannenberg, A.M. (1972). Macrophage accumulation, division, maturation, and digestive and microbicidal capacities in tuberculous lesions. IV. Macrophage turnover, lysosomal enzymes, and division in healing lesions. Lab. Invest. 27: 466-472.

Angus, K.W. (1990). Intestinal lesions resembling paratuberculosis in a wild rabbit (Oryctolagus cuniculus). J. Comp. Path. 103: 101-105.

Aranaz, A.; De Juan, L.; Montero, N.; Sánchez, C.; Galka, M.; Delso, C.; Álvarez, J.; Romero, B.; Bezos, J.; Vela, A.I.; Briones, V.; Mateos, A. y Domínguez, L. (2004). Bovine tuberculosis (Mycobacterium bovis) in wildlife in Spain. J. Clin. Microbiol. 42: 2602-2608.

Araujo, Z.; Acosta, M.; Escobar, H.; Baños, R.; Fernández de Larrea, C. y Rivas-Santiago, B. (2008). Respuesta inmunitaria en tuberculosis y el papel de los antígenos de secreción de Mycobacterium tuberculosis en la protección, patología y diagnóstico. Revisión. Invest. Clin. 49(3): 411-441. 
Arcelles, P.M.; Delgado, C.A.; Alzamora, P.C.; Manchego, S.A. y Gavidia, C.C. (2005). Prevalencia de tuberculosis bovina en el distrito de Végueta, Huaura. Rev. Inv. Vet. Perú. 16: 154-157.

Arellano-Reynoso, B.; Ramírez-Casillas, I.C.; Díaz-Aparicio, E.; Valero-Elionzo, G. y Santillán-Flores, M.A. (1999). Diagnóstico de tuberculosis en hatos de caprinos empleando la prueba intradérmica doble comparativa y cultivo bacteriológico. Tec. Pecu. Méx. 37: 55-58.

Ayele, W.Y.; Machackova, M. y Pávlik, I. (2001). The transmission and impact of paratuberculosis infection in domestic and wild ruminants. Vet. Med. Czech. 46: 205-224.

Badiola, J.J.; García de Jalón, J.A. y Cuervo, L. (1979). Paratuberculosis ovina. An. Fac. Vet. Zaragoza. XIVXV: 299:308.

Balseiro, A.M. (2004). Paratuberculosis bovina: valoración de las reacciones cruzadas con la prueba de la tuberculina, evaluación de técnicas diagnósticas y prevalencia en Asturias. Tesis Doctoral. Universidad de León.

Balseiro, A.; Prieto, J.M.; Espí, A.; Pérez, V. y García-Marín, J.F. (2003). Presence of focal and multifocal paratuberculosis lesions in mesenteric lymph nodes and ileocaecal valve of cattle positive to the tuberculin skin test. Vet. J. 166: 210-212.

Balseiro, A.; García-Marín, J.F.; Solano, P.; Garrido, J.M. y Prieto, J.M. (2008). Histopathological classification of lesions observed in natural cases of paratuberculosis in free-ranging fallow deer (Dama dama). J. Comp. Path. 138: 180-188.

Balseiro, A.; González-Quirós, P.; Rodríguez, Ó.; Francisca Copano, M.; Merediz, I.; de Juan, L.; Chambers M.A.; Delahay, R.J.; Marreros, N.; Royo, L.J.; Bezos, J.; Prieto, J.M. y Gortázar, C. (2013). Spatial relationships between Eurasian badgers (Meles meles) and cattle infected with Mycobacterium bovis in Northern Spain. Vet. J. 197(3): 739-745.

Band, H.; Panchamoorthy, G.; Mclean, J.; Morita, C.T.; Ishikawa, S.; Modlin, R. y Brenner, M.B. (1991). Recognition of mycobacterial antigens by gd T cells. $33^{\text {rd }}$ Forum in Immunology. 645-651.

Bang, B. (1906). Chrinische psuedotuberkuloese darmentzuendung beim rinde. Berl. Tieraerztl. Wschr. 42: 759-763.

Bannantine, J.P. y Stabel, J.R. (2002). Killing of Mycobacterium avium subspecie paratuberculosis within macrophages. BMC Microbiology. 2: 2.

Bannantine, J.P.; Paustian, M.L.; Waters, W.R.; Stabel, J.R.; Palmer, M.V.; Lingling, L. y Kapur, V. (2008). Profiling bovine antibody responses to Mycobacterium avium subsp. paratuberculosis infection by using protein arrays. Infect. Immun. 76: 739-749.

Barker, I.K..; Dreumel, A.A. y Palmer, N. (1993). The alimentary system. In: Pathology of domestic animals. Jubb, K.V.F.; Kennedy, P.C.; Palmer, N. Academic press. 2: 247-252- Londres, Reino Unido.

Barrón, H.; Monteghirfo, M. y Rivera, N. (2006). Diagnóstico molecular de Mycobacterium tuberculosis en biopsias pleurales embebidas en parafina. An. Fac. Med. Lima. 67: 11-18.

Bauerfeind, R.; Benazzi, S.; Weiss, R.; Schliesser, T.; Willems, H. y Baljer, G. (1996). Molecular characterization of Mycobacterium paratuberculosis isolates from sheep, goats and cattle by hybridization with a AND probe to insertion element IS900. J. Clin. Microbiol. 34: 1617-1621.

Baver, J.; Thomesen, V.O.; Poulsen, S. y Andersen, A.B. (1997). False-positive results from cultures of Mycobacterium tuberculosis due to laboratory cross-contamination confirmed by restriction fragment length polymorphism. Vet. Microbiol. 35: 988-991. 
Beach-Nielsen, S.; Jorgensen, J.B.; Ahrens, P. y Feld, N.C. (1992). Diagnostic accuracy of a Mycobacterium phei absorbed serum enzyme-linked immunosorbent assay for diagnosis of bovine paratuberculosis in dairy cows. J. Clin. Microbiol. 30: 613-618.

Beach-Nielsen, S.; Shulaw, W.P.; Frandsen, P.L.; Jorgensen, J.B.; Ahrens, P. y Feld, N.C. (1993). Use of a dot enzyme-linked immunosorbent assay on absorbed sera for the diagnosis of bovine paratuberculosis. Res. Sci. Tech. Off. Int. Epiz. 12: 617-627.

Beard, P.M.; Daniels, M.J.; Henderson, D.; Pirie, A.; Rudge, K.; Buxton, D.; Rhid, S.; Greig, A.; Hutchings, M.R.; McKendrick, I.; Stevenson, K. y Sharp, J.M. (2001). Paratuberculosis infection of nonruminant wildlife in Scotland. J. Clin. Microbiol. 39: 1517-1521.

Beer, J. (1981) Enfermedades infecciosas de los animales domésticos. Tomo II. p. 229-249. Ed. Acribia. España.

Belknap, E.B.; Getzy, D.M.; Johnson, L.W.; Ellis, R.P.; Thompson, G.L. y Shulaw, W.P. (1994). Mycobacterium paratuberculosis infection in two llamas. J. Am. Vet. Med. Assoc. 204: 1805-1808.

Bendixen, P.H. (1978). Immunological reactions caused by infection with Mycobacterium paratuberculosas. A review. Nord. Vet. Med. 30: 163-168.

Bendixen, P.H.; Bloch, B. y Berg-Jorgensen, J. (1981). Lack of intracellular degradation of Mycobacterium paratuberculosis by bovine macrophages infected in vitro and in vivo: light microscopic and electron microscopic observations. Am. J. Vet. Res. 42: 109-113.

Bengis, R.G.; Kriek, N.P.J.; Keet, D.F.; Raath, J.P.; De Vos, V. y Huchzermeyer, H. (1996). An outbreak of tuberculosis in a free-living African buffalo (Syncerus Caffer SPARRMAN) population in the Kruger National Park: a preliminary report. Onderstepoort. J. Vet. Res. 63: 15-18.

Berger, S.; Dominik, H.; Bannantine, J.P. y Griffin, J.F. (2006). Isolation of high-affinity-single-chain antibodiesagainst Mycobacterium avium subsp. paratuberculosis surface proteins from sheep with Johne's disease. Clin. Vacc. Immunol. 13: 1022-1029.

Bergey, D.H.; Harrison, F.C.; Breed, R.S.; Hammer, B.W. y Huntoon, F.M. (1923). En: Bergey’s manual of determinative bacteriology. Ed. Williams and Wilkins, $1^{\text {st }}$ ed. Baltimore, E.E.U.U.

Bergmann, J.S.; Keatin, W.E. y Woods, G.L. (2000). Clinical evaluation of the BDProbeTec ET system for rapid detection of Mycobacterium tuberculosis. J. Clin. Microbiol. 38: 863-865.

Bernardelli, A.; Cicuta, M.E.; Nicola, A.; Roibón, W.R.; Boehringer, S.I.; Benítez, M.C.; Barceló, M.C.; Alonso, B.; Alonso, Z.; Schneider, M.; Zumárraga, M. y Estéves, M.J. (2002). Paratuberculosis ovina en Corrientes, Argentina. En línea consultado: 26 de enero 2011. www. Une.edu.ar/Web/cyt/cyt/2002/04Veterinarias/V-058.pdf

Bernabé, A.; Gómez, M.A.; Navarro, J.A.; Gómez, S.; Sanchéz, J.; Sidrach, J. y Menchén, V. (1991). Pathological changes of spontaneous dual infection of tuberculosis and paratuberculosis in goats. Small Rumin. Res. 5: 377-390.

Beyerbach, M.; Rehm, T.; Kreienbrock, L. y Gerlach, G.F. (2001). Eradication of paratuberculosis in dairy herds: determination of the initial herd prevalence and modelling of prevalence development. Dtsch.Tierarztl.Wochenschr. 108: 291-6.

Billman-Jacobe, Carrigan, M.; Cockram, F.; Corne, L.A.; Gill, I.J.; Hill, J.F.; Jessep, T.; Milner, A.R. y Wood, P.R. (1992). A comparison of the interferon gamma test assay with the absorbed ELISA for the diagnosis of Jhone's disease in cattle. Aus. Vet. J. 69: 25-28. 
Blaha, T. (1995). Epidemiología especial veterinaria. Acribia. 164-172. España.

Blood, D.C.; Radostits, O.M.; Arundel, J.H. y Gay, C.C. (1989). Paratuberculosis (John's disease). En: Vet. med. Balliére and Tindall. 722-729. Londres, Reino Unido.

Boelaert, F.; Walravens, K.; Biront, P. y Berkvens, D. (2008). Prevalence of paratuberculosis (Johne's disease) in the Belgian cattle population. Vet. Microbiol. 77: 269-281.

Bölske, G.; Englund, S.; Johansson, K.E. y Königsson, M.H. (2002). False positive Mycobacterium avium subsp. paratuberculosis IS900 PCR and its diagnostic implications. Proc. VII Int. Coll. PTBC. 261-266. Bilbao, España.

Bourne, F.J.; Donelly, C.; Cox, D.; Gettinby, G.; Mclnerney, J.; Morrison, I. y Woodroffe, R. (2007). Bovine TB: The Scientific evidence, a science base for a sustainable policy to control TB in cattle, an epidemiological investigation into bovine tuberculosis. Final report of the independent scientific group on cattle TB. Departament for environment, Food and rural affairs.

Bouvier, G.; Burgisser, H. y Schneider. (1957). Observations sur les maladies du gibier, des oiseaux et des poisons faites en 1955 et 1956. Schweiz Arch. Tierheilk. D. 99: 461-477. Citado por: Morris, R.S., Pfeiffer, D.U. y Jackson, R. (1994). The epidemiology of Mycobacterium bovis infections. Vet. Microbiol. 40:153-177.

Brady, C.; Grady, D.; O`Meara, F.; Egan, J. y Bassett, H. (2008). Relationships between clinical signs, pathological changes and tissue distribution of Mycobacterium avium subspecies paratuberculosis in 21 cows from herds affected by Johne's disease. Vet. Rec. 162: 147-152.

Brees, D.J.; Reimer, S.B.; Cheville, N.F.; Florance, A. Y Thoen, C.O. (2000). Immunohistochemical detection of Mycobacterium paratuberculosis in formalin-fixed, paraffin-embedded bovine tissue sections. $J$. Vet. Diagn. Invest. 12: 60-63.

Brodbeck, W.G. y Anderson, J.M. (2009). Giant cell formation and function. Curr. Opin. Hematol. 16(1): 53-57.

Brown, A.E.; Holzer, T.J. y Andersen, B.R. (1987). Capacity of human neutrophils to kill Mycobacterium tuberculosis. J. Infect. Dis. 156: 985-989.

Brown, C.C; Barker, D.C. y Barker, I.K. (2007). The alimentary system paratuberculosis (Johne's disease). En: Jubb, K.V.F.; Kennedy, P.C.; Palmer, N. Pathology of domestic animals. $5^{\text {th }}$ ed. Elsevier Saunders. Londres, Reino Unido. 2: pp. 222-225.

Brown, W.H. y Hernández de Anda, J. (1998). Tuberculosis in adult beef cattle of Mexican origin shipped direct-to-slaugther into Texas. J. Am. Vet. Med. Assoc. 212: 557-559.

Brumbaugh, G.W.; Edwards, J.F.; Roussel, A.J. Jr. y Thomson, T.D. (2000). Effect of monensin sodium on histological lesions of naturally occurring bovine tuberculosis. J. Comp. Pathol. 123: 22-28.

Buddle, B.M.; Aldwel, F.F.; Pfeffer, A.; De Lisle, G.W. y Corner, L.A. (1994). Experimental Mycobacterium bovis infection of cattle- effect of dose of Mycobacterium bovis and pregnancy on immune responses and distributions of lesions. N. Z. Vet. J. 42: 167-172.

Buddle, B.M.; de Lisle, G.W.; Pfeffer, A. y Aldwel, F.F. (1995). Immunological response and protection against Mycobacterium bovis in calves vaccinates with a low dose of BCG. Vaccine. 13: 1123- 30.

Buddle, B.M.; Pollock, J.M.; Skinner, M.A. y Wedlock, N. (2003). Development of vaccines to control bovine tuberculosis in cattle and relationship to vaccine development for other intracellular pathogens. Int. J. Parasitol. 33: 555-566. 
Buergelt, C.D.; Hall, C.; Mc Entee, K. y Duncan, J.R. (1978). Pathological evaluation of paratuberculosis in naturally infected cattle. Vet Path. 39: 591-595.

Buergelt, C.D. y Wlliams, J.E. (2004). Nested PCR on blood and milk for the detection of Mycobacterium avium subsp. Paratuberculosis DNA in clinical and subclinical bovine paratuberculosis. Aust. Vet. J. 82(8): 497-503.

Buergelt, C.D. y Ginn, P.E. (2000). The histopathologic diagnosis of subclinical Johne's disease in North American bison (Bison bison). Vet. Microbiol. 77: 325-331.

Bulaga, L.L. y Collins, M.T. (1999). U.S. voluntary Johne's disease herd status program for cattle. Proc. VI Int. Coll. PTBC. 39-47.

Bull, T.J.; Hermon-Taylor, J.; Pávlik, I.; El-Zaatari, F. y Tizard, M. (2000). Characterization of IS900 oci in Mycobacterium avium subsp. paratuberculosis and development of multiplex PCR typing. Microbiology. 146: 2185-2197.

Burrells, C.; Inglis, N.F.; Davies, R.C. y Sharp, J.M. (1995). Detection of specific T cell reactivity in sheep infected with Mycobacterium avium subspecies silvaticum and paratuberculosis using two defined mycobacterial antigens. Vet. Immunol. Immunopathol. 45: 311-320.

Burrells, C.; Clarke, C.J.; Colston, A.; Kay, J.M.; Porter, J.; Little, D. y Sharp, J.M. (1998). A study of responses of sheep clinically-affected with paratuberculosas (Johne's disease). The relationship of blood, mesenteric lymph node and intestinal lymphocyte responses to gross and microscopic pathology. Vet. Immunol. Immunopathol. 66: 343-358.

Caffrey, J.P. (1994). Status of bovine tuberculosis eradication programs in Europe. Vet. Microbiol. 40: 1-4.

Calderón, J. y Gongóra, O.A. (2008). Similitudes clinicopatológicas entre paratuberculosis y enfermedad de Crohn. ¿Posible vínculo zoonótico?. Rev. MVZ Córdoba. 13: 1226-1239.

Carrigan, M.J. y Seaman, J.T. (1990). The pathology of Johne's diseases in sheep. Aust. Vet. J. 67: 47-50.

Castillo, M.O.; Martínez, B.J.; Solano, T.D.; Velásquez, Z.A.; De la Cruz, H.N.; Campuzano, G.J.; Acosta, M.F.; Snydellar, H.A.; Almazán, G.C.C. y Ramos, V.J. (2010). Estandarización de la técnica de inmunohistoquímica para el diagnóstico de tuberculosis bovina en Tamaulipas. En línea consultado: el 13 de Mayo del 2010. http://www.cotacyt.gob.mx/congreso/memoria/fscommand/agropecuario/ana.pdf

Centers for Diseases Control and Prevention. (2005). Human tuberculosis caused by Mycobacterium bovis infections, New York City, 2001-2004. MMWR. 54: 605-608.

Challans, J.A.; Stevenson, K.; Reid, H.W. y Sharp, J.M. (1994). A rapid method for the extraction and detection of Mycobacterium avium subspecies paratuberculosis from clinical specimens. Vet. Rec. 134: 9596.

Chaussé, P. (1913). Des méthodes á employer pour réaliser la tuberculose expérimentale par inhalation. Bull. Soc. Med. Vet. 31: 267-274. Citado por: O’Reilly, L.M. y Daborn, C.J. (1995). The epidemiology of Mycobacterium bovis infections in animals and man: a review. Tubercle Lung Dis. 76: 1-46.

Chávez, G. (2005). Control de la paratuberculosis en ovinos y caprinos. En línea consultado: 12 de mayo 2011. www.conasamexico.org/mesa4Introduccion.

Chávez, G.G.; Trigo, T.F.J.; Svastova, P. e Ivo, P. (2004). Identificación del polimorfismo genético de aislamientos de Mycobacterium avium subespecie paratuberculosis de caprinos del centro de México. Vet. Méx. 35(1). 
Chedore, P. y Jamieson, F.B. (1999). Routine use of Gen-Probe MTD2 amplification test for detection of Mycobacterium tuberculosis in clinical specimens in a large public health mycobacteriology laboratory. Diagn. Microbiol. Infect. Dis. 35: 185-191.

Cheville, N.F.; Hostetter, J.; Thomsen, B.V.; Simutis, F.; Vanloubbeeck, Y. y Steadham, E. (2001). Intracellular trafficking of Mycobacterium avium ss. paratuberculosis in macrophages. Dtsch. Tierarztl. Wochenschr. 108: 236-243.

Chiodini, R.J. y Van Kruiningen, H.J. (1983). Eastern with-tailed deer as a reservoir of ruminant paratuberculosis. J. Am. Vet. Med. Assoc. 182: 168-169.

Chiodini, R.J.; Van Kruiningen, H.J. y Merkal, R.S. (1984). Ruminant paratuberculosis (Johne's disease): The current status and future prospects. Cornell Vet. 74: 218-262.

Chiodini, R.J. y Van Kruiningen, H.J. (1985). Characterization of Mycobacterium paratuberculosis of bovine, caprine, and ovine origin by-gas-liquid chromatographic analysis of fatty acids in whole cell extracts. Am. J. Vet. Res. 46: 1980-1989.

Chiodini, R.J. y Van Kruiningen, H.J. (1986). The prevalence of paratuberculosis in culled New England cattle. Cornell. Vet. 76: 91-104.

Chiodini, R.J. (1989). Crohn's disease and the mycobacterioses: a review and comparison of two disease entities. J. Clin. Microbiol. 2: 90-117.

Cicuta, M.E.; Boehringer, S.I.; Roibón, W.R.; Benítez, M.C. y Barceló, M.C. (2003) Validez de la prueba tuberculínica para el diagnóstico de paratuberculosis ovina. Universidad Nacional del Nordeste. Comunicaciones Científicas y Tecnológicas. Resumen V-016.

Clarke, C.J. (1994). Host responses to Mycobacterium paratuberculosis/M. avium infection. Prc. IV Int. Ass. PTBC. 345-354.

Clarke, C.J. (1997). The pathology and pathogenesis of paratuberculosis in ruminants and other species. $J$. Comp. Path. 116: 217-261.

Clarke, C.J. y Little, D. (1996). The pathology of ovine paratuberculosis: gross and histological changes in the intestine and other tissues. J. Comp. Pathol. 114: 419-437.

Clarke, C.J.; Patterson, I.A.; Armstrong, K.E. y Low, J.C. (1996). Comparison of the absorbed ELISA and agar gel immunodiffusion test with clinicopathological findings in ovine clinical paratuberculosis. Vet. Rec. 139: 618-621.

Clifton-Hadley, R.S. y Wilesmith, J.W. (1991). Tuberculosis in deer: a review. Vet. Rec. 129: 5-12.

Cocito, C.; Gilot, P.; Coene, M.; Kesel, M.; Pouspart, P. y Vannufel, P. (1994). Paratuberculosis. Clin. Microbiol. Rev. 7: 328-344.

Coetsier, C.; Havaux, X.; Mattelard, F.; Sadatte, S.; Cormont, F.; Buerguelt, K.; Limbourg, B.; Latinne, D.; Bazin, H.; Denef, J.F. y Cocito, C. (1998). Detection of Mycobacterium avium subsp. paratuberculosis in infected tissues by new species-specific immunohistological procedures. Clin. Diagn. Lab. Immunol. 5: 446451.

Coetsier, C.; Vannuffel, P.; Blondeel, N.; Denef, J.F.; Cocito, C. y Gala, J.L. (2000). Duplex PCR for differential identification of Mycobacterium bovis, M. avium and M. avium subsp. paratuberculosis in formalin-fixed paraffin-embedded tissues from cattle. J. Clin. Microbiol. 38: 3048-3054. 
Coetsier, C.; Vannuffel, P.; Blondeel, N.; Denef, J.F.; Cocito, C. y Gala, J.L. (2001). Duplex PCR for differential identification of Mycobacterium bovis, M. avium and M. avium subsp. paratuberculosis in formalin-fixed paraffin-embedded tissues from cattle. J. Clin. Microbiol. 32: 2048-2054.

Colgrove, G.S.; Thoen, C.O.; Blackburn, B.O. y Murphy, C.D. (1989). Paratuberculosis in cattle: a comparison of three serologic tests with results of fecal culture. Vet. Microbiol. 19: 183-187.

Collins, J.D. (2006). Tuberculosis in cattle: strategic planning for the future. Vet. Microbiol. 112: 369-381.

Collins, M.T. (1996) Diagnosis of paratuberculosis. Vet. Clin. North. Am. Food Anim. Pract. 12: 357-371.

Collins, M.T. (2004). Update on paratuberculosis: control and zoonótica potential. Irish. Vet. J. 57: 49-52.

Collins, D.M.; Gabric, D.M. y De Lisle, G.W. (1990). Identification of two groups of Mycobacterium paratuberculosis strains by restriction endonuclease analysis and hybridization. J. Clin. Microbiol. 28: 15911596.

Collins, D. M.; Stephens, D.M. y de Lisle, G.W. (1993a). Comparison of polymerase chain reaction test and faecal culture for detecting Mycobacterium paratuberculosis in bovine faeces. Vet. Microbiol. 36: 289-299.

Collins, D.M.; Angulo, A.; Buerguelt, C.D.; Hennager, S.G.; Hietala, S.K.; Jacobson, R.H.; Whippled, D.L. y Whitlock, R.H. (1993b). Reproductibility of a commercial enzyme-linked immunosorbent assay for bovine paratuberculosis among eight laboratories. J. Vet. Diagn. Invest. 5: 52-55.

Collins, D. M.; de Lisle, G.W.; Collins, J.D. y Costello, E. (1994). DNA restriction fragment typing of Mycobacterium bovis isolates from cattle and badgers in Ireland. Vet. Rec. 134: 681-682.

Collins, D. M.; de Zoete, M. y Cavaignac, S.M. (2002). Mycobacterium avium subsp. paratuberculosis strains from cattle and sheep can be distinguished by a PCR test based on a novel DNA sequence difference. J. Clin. Microbiol. 40: 4760-4762.

Condron, R.J.; Schroen, C.J.; Black, C.A.; Ridge, S.E. y Hope, A.F. (1994). Histological confirmation of subclinical infection with M. paratuberculosis in cattle. En: Chiodini, R.J.; Collins, M.T. y Bassey, E.O.E. (Eds). Proc. $4^{\text {th }}$ Int. Coll. PTCB. IAP. Providence. EEUU. pp. 37-40.

Contreras, J.A. (2000). Enfermedades de los bovinos. $2^{\text {da }}$ Edición. Editorial Bogue. Barquisimeto. $560-583$. Cooke, M.M., Jackson, R. y Coleman, J.D. (1993). Tuberculosis in a free-living brown hare (Lepus europeaus occidentalis) .New Zeal. Vet. J. 41: 144-146.

Corner, L.A. (1994). Bovine tuberculosis: pathology and bacteriology. In Australian standard diagnostic techniques for animal diseases (L.A. Corner \& T. J. Bagust, edit.). CSIRO for the standing committee on agriculture and resource, management, east melbourne, 8 págs.

Corner, L.A. y Pearson, C.W. (1978). Pathogenicity for cattle of atypical micobacteria isolated from feral pigs and cattle and the correlation of lesions with tuberculin sensitivity. Aust. Vet. J. 54: 280-286.

Corner, L.A.; Melville, L.; McCubbin, K.; Small, K.J.; McCormick, B.S.; Wood, P.R. y Rothel, J.S. (1990). Efficiency of inspection procedures for the detection of tuberculosis lesions in cattle. Austalian Veterinary J. 67: 389-392.

Corner, L.A.; Wood, P.R. y Rothel, J.S. (1991). Reply to the correspondence: Efficiency of inspection procedures for the detection of tuberculous lesions in cattle. Austr. Vet. J. 68: 218-219.

Coromoto, A.; Morela, R.C. y Alberto, V. (2006). Caracterización de la paratuberculosis bovina en ganado doble propósito de los llanos de Monagas, Venezuela. Zoo. Trop. 24: 321-332. 
Corpa, J.M. (1999). Aspectos inmunopatológico de la paratuberculosis de los pequeños rumiantes. Respuesta inmune asociada a la vacunación. Tesis doctoral. Universidad de León.

Corpa, J.M.; Kalis, C.H.; García Marín, J.F. y Pérez, V. (1998a). Diagnóstico de la paratuberculosis en el ganado vacuno. Med. Vet. 618-624.

Corpa, J.M.; Kalis, C.H.; García Marín, J.F. y Pérez, V. (1998b). Evolución de la respuesta inmune frente a paratuberculosis en ganado ovino y caprino según la edad de vacunación. Producción ovina y caprina. 23: 283-286.

Corpa, J.M.; Garrido, J.; García Marín, J.F. y Pérez, V. (2000). Classification of lesions observed in natural cases of paratuberculosis in goats. J. Comp. Path. 122: 255-265.

Cosivi, O.; Grange, J.M.; Daborn, C.J.; Raviglione, M.C.; Fujikura, T.; Cousins, D.; Robinson, R.A.; Huchzermeyer, H.F.; de Kantor, I. y Meslin, F.X. (1998). Zoonotic tuberculosis due to Mycobacterium bovis in developing countries. Emerg. Infect. Dis. 4: 59-70.

Costello, E.; Doherty, M.L.; Monaghan, M.L.; Quigley, F.C. y O’Reilly, P.F. (1998). A study of cattle-tocattle transmission of Mycobacterium bovis infection. Vet. J. 155: 245-250.

Cousins, D.V. (2001). Mycobacterium Bovis infection and control in domestic livestock. Rev. Sci. Tech. Epiz. 20: $71-85$

Cousins, D.V.; Wilton, S.; Francis, B. y Gow, B. (1992). Use of polymerase chain reaction for rapid diagnosis of tuberculosis. J. Clin. Microbiol. 30 (1): 255-258.

Cousins, D.V.; Williams, S.N.; Reuter, R.; Forshaw, D.; Chadwick, B.; Coughran, D.; Collins, P. y Gales, N. (1993). Tuberculosis in wild seals and characterization of the bacillus. Aust. Vet. J. 70: 92-97.

Cousins, D.V.; Whittington, R.; Marsh, I.; Masters, A.; Evans, R.J. y Kluver, P. (1999). Mycobacteria distinct from Mycobacterium avium subsp. paratuberculosis isolated from the faeces of ruminants posses IS900-like sequences detectable IS900 polymerase chain reaction: implications for diagnosis. Mol. Cell. Probes. 13: 431442.

Cuezva Samaniego, J. (1966). Erradicación de la tuberculosis bovina. Ed. Avigan, Valencia.

Cuezva Samaniego, J. y De la Encina, J. (1958). Campaña de erradicación de tuberculosisi bovina en Vizcaya. Estudio de las lesiones encontradas en las reses sacrificadas. Vterinaria. 7: 613-621.

Daffe, M. y Draper, P. (1998). The envelope layers of mycobacteriawith reference to their pathogenicity. Adv. Microb. Physiol. 39: 131-203.

Dahme, E. y Weiss, E. (1988). Tuberculosis. En: Anatomia Patológica Especial Veterinaria. Ed. Acribia. Zaragoza.

Daniels, M.J.; Ball, N.; Hutchings, M. y Greig, A. (2001). The grazing response of cattle to pasture contamined with rabbit faeces and the implications for the transmission of paratuberculosis. Vet. J. 161: 306313.

Daniels, M.J.; Henderson, D.; Greig, A.; Stevenson, K.; Sharp, J.M. y Hutchings, M.R. (2003a). The potential role of wild rabbits Oryctolagus cuniculus in the epidemiology of paratuberculosis in domestic ruminants. Epidemiol. Infect. 130: 553-559.

Daniels, M.J.; Hutchings, M.R.; Beard, P.M.; Henderson, D.; Greig, A.; Stevenson, K. y Sharp, J.M. (2003b). Does non-ruminants wildlife pose a risk of paratuberculosis to domestic livestock and vice versa in Scotland? J. Wildl. Dis. 39: 10-15. 
Daniels, M.J.; Hutchings, M.R. y Greig, A. (2003c). The risk of disease transmission to livestock posed by contamination of farm stored feed by wildlife excreta. Epidemiol. Infect. 130: 561-568.

Delgado, F.; Etchechoury, D.; Gioffré, A.; Paolicchi, F.; Blanco Viera, F.; Mundo, S. y Romano, M.I. (2009). Comparison between two in situ methods for Mycobacterium avium subsp. paratuberculosis detection in tissue samples from infected cattle. Vet. Microbiol. 134: 383-387.

Delgado, L.; Marín, J.F.; Muñoz, M.; Benavides, J.; Juste, R.A.; García-Pariente, C.; Fuertes, M.; González, J.; Ferreras, M.C. y Pérez, V. (2013). Pathological in Young and adult sheep following experimental infection with 2 different doses of Mycobacterium avium subspecies paratuberculosis. Vet. Pathol. 50(5): 857-866.

de Lisle, G.W.; Welch, P.J.; Havill, P.F.; Julian, A.F.; Poole, W.S.; Corrin, K.C. y Gladden, N.R. (1983). Experimental tuberculosis in red deer (Cervus elaphus). N. Z. Vet. J. 31(12): 213-216.

de Lisle, G.W. y Milestones, B.A. (1989). The economic impact of Johne's disease in New Zeland. En:hne's disease current trends in research and management. Milner, A.R. y Wood, P.R. (Eds.) CSIRO: 41-45. Melbourne, Australia.

de Lisle, G.W.; Yates, G.F. y Collins, D.M. (1993). Paratuberculosis in farmed deer: case reports and DNA characterization of isolates of Mycobacterium paratuberculosis. J. Vet. Diagn. Invest. 5: 567-571.

de Lisle, G.W.; Mackintosh, C.G. y Bengis, R.G. (2001). Mycobacterium bovis in free-living and captive wildlife, including farmed deer. Rev. Sci. Tech. Off. Int. Epiz. 20: 86-111.

Delahay, R.J.; de Leeuw, A.N.; Barlow, A.M.; Clifton-Hadley, R.S. y Cheeseman, C.L. (2002). The status of Mycobacterium bovis infection in UK mammals: a review. Vet. J. 164: 90-105.

Dey, B.P. y Parham, G.L. (1993). Incidence and economics of tuberculosis in swine slaughtered from 1976 to 1988. J. Am. Vet. Med. Assoc. 203: 516-519.

Díaz, O.F.; Masso, F.; Paez, A.; Varela, E.; Suarez, F. y Montaño, L.F. (1999). Secretion of IFN- $\gamma$ by bovine peripheral blood mononuclear cells stimulated with Mycobacterium bovis protein fractions obtained by isoelectric- focusing. Vet. Immunol. Immunopathol. 67: 203-212.

Djonne, B.; Jensen, MR.; Grant, I.R. y Holstad, G. (2003). Detection by immunomagnetic PCR of Mycobacterium avium subsp. paratuberculosis in milk from dairy goats in Norway. Vet. Microbiol. 92: 135143.

Dohmann, K.; Strommenger, B.; Stevenson, K.; De Juan, L.; Stratmann, J.; Kapur, V.; Bull, T. J. y Gerlach, G.F. (2003). Characterization of genetic difference between Mycobacterium avium subsp. paratuberculosis type I and type II isolates. J. Clin. Microbiol. 41: 5215-5223.

Dolz, G.; Araya, L.N.; Suárez, J. y Jiménez, C. (1999). Prevalence of antibodies to bovine paratuberculosis detected by a LAM-ELISA in Costa Rica. Vet. Rec. 144: 322-323.

Doyle, T.M. (1954). Isolation of Johne's bacilli from the udders of clinically infected cows. Br. Vet. J. 110: 215-218.

Doyle, T.M. y Spears, H.N. (1951). A johne's disease survey. Vet. Rec. 20: 355-363.

Draper, P. (1982). The anatomy of micobacteria. In: The biology of micobacteria. Vol. 1. Ratledge, C., Stanford, J.L., Eds., Academic press, London, pp. 9-52. Citado por: Pritchard, D.G. (1988). A century of bovine tuberculosis 1888-1988: Conquest and controversy. J. Comp. Path. 99: 357-398.

Dungworth, D.I. (1993). The respiratory system. En: Pathology of domestic animals. Jubb, K.V.F.; Kennedy, P.C. y Palmer, N. (Ed.) Academic press. $4^{\text {th }}$ ed. 2: 493-504. Londres, Reino Unido. 
Dunkin, G.W. (1934). Johne's disease. It is economic significance and early detection. Vet. Rec. 14: 15511559 .

Eamens, G.J.; Whittington, R.J.; Marsh, I.B.; Turner, M.J.; Sanders, V.; Kemslay, P.D. y Rayward, D. (2000). Comparative sensitivity of various fecal culture methods and ELISA in dairy cattle herds with endemic Johne's disease. Vet. Microbiol. 77: 357-367.

Edwards, D. y Kirkpatrick, C.H. (1986). The immunology of mycobacterial diseases. Am. Rev. Respir. Dis. 134: 1062-1071.

Englund, S. (2003). IS900/ERIC-PCR as a tool to distinguish Mycobacterium avium subsp. paratuberculosis from closely related micobacteria. Vet. Microbiol. 96: 277-287.

Eppleston, J. y Whittington, R.J. (2001). Isolation of Mycobacterium avium subsp. paratuberculosis from the semen of rams with clinical Johne's disease. Aust. Vet. J. 79: 776-777.

Erume, J.; Spengser, J. y Rosengarte, R. (2000). Rapid detection of Mycobacterium avium subsp. Paratuberculosas from cattle and zoo animals by nested PCR. African Health Sci. JCM. 1: 83-89.

Escobar, A.L.; Coimbra, C.E.; Camacho, L.A. y Santos, R.V. (2004). Tuberculin reactivity and tuberculosis epidemiology in the Pakaanóva (Wari') Indians of Rondonia, south-western Brazilian Amazon. Int. J. Tuberc. Lung. Dis. 8(1): 45-51.

Escobar, J.I.; Mejía, W. y González, J.C. (2003). Búsqueda activa de sintomáticos respiratorios para tuberculosis en poblaciones de alto riesgo. Rev. Fac. Nac. Sal. Pub. 21: 9-20.

Estévez-Denaives, I.; Hernández, R.; Trujillo, A.M. y Chávez, G. (2007). Detection of Mycobacterium avium subsp. paratuberculosis in goat and sheep flocks in México. Small. Rum. Res. 72: 209-213.

Estrada-Chávez, C.; Mancilla, R.; Arriaga, D.C.; Pérez, G.R. y Díaz, O.F. (2001). Determinación de anticuerpos anti-PPD en hatos lecheros con distintas prevalencias de tuberculosis bovina en México. Vet. Mex. 32: 207-211.

Estrada-Chávez, C.; Díaz, F.; Arriaga, C.; Villegas-Sepúlveda, M.; Pérez, R. y González, D. (2004). Concordancia de la PCR y métodos rutinarios para el diagnóstico de tuberculosis bovina. Vet. Méx. 35: 225236.

European Commission. Health and Consumer Protection Directorate-General. (2003). Report on trends and sources of zoonotic agents in the European Union and Norway. http: //ec.europa.eu./food/food/biosafety/salmonella/zoonoses_reps_2003_en.htm

Fawcett, A.R.; Goddard, P.J.; McKelvey, W.A.; Buxton, D.; Reid, H.W.; Greig, A. y McDonald, A.J. (1995). Johne's disease in a herd of farmed red deer. Vet. Rec. 18: 165-169.

Feldman, W.H. y Fitch, C.P. (1936). Histologic features of the intradermic reaction to tuberculin in cattle. Arch. Pathol. 22: 495-509.

Feola, R.P.; Collins, M.T. y Czuprynsky, C.J. (1999). Hormonal modulation of fagocitosis and intracellular growth of Mycobacterium avium ss. paratuberculosis in bovine peripheral blood monocytes. Microb. Pathogen. 26: 1-11.

Ferreira, R.; Fonseca, L.S. y Lilenbaum, W. (2002). Agar gel immunodiffusion test (AGID) evaluation for detection of bovine paratuberculosis in Rio de Janeiro, Brazil. Lett. Appl. Microbiol. 35: 173-175.

Ferreras, P. (1915). Sobre la enfermedad de Johne. Rev. Vet. Esp. 9: 277-283. 
Fifis, T.; Costopoulos, C.; Corner, L.A.A. y Wood, P.R. (1992). Serological reactivity to Mycobacterium bovis protein antigens in cattle. Vet. Microbiol. 30: 343-354.

Fisher, O.A.; Matlova, L.; Dvorska, L.; Svastova, P.; Bartl, J.; Melicharek, I.; Weston, R.T. y Pávlik, I. (2001). Diptera as vectors of mycobacterial infections in cattle and pigs. Med. Vet. Entomol. 15: 208-211.

Fisher, O.A.; Matlova, L.; Bartl, J.; Dvorska, L.; Svastova, P.; Du Maine, R.; Melicharek, I.; Bartos, M. y Pávlik, I. (2003a). Earthworms (Oligochaeta Lumbricidae) and micobacteria. Vet. Microbiol. 91: 325-338.

Fisher, O.A.; Matlova, L.; Dvorska, L.; Svastova, P. y Pávlik, I. (2003b). Nymphs of the Oriental cockroach (Blatta orientalis) as passive vectors of causal agents of avian tuberculosis and paratuberculosis. Med. Vet. Entomol. 17: 145-150.

Fisher, O.A.; Matlova, L.; Dvorska, L.; Svastova, P.; Bartl, J.; Weston, R.T. y Pávlik, I. (2004). Blowflies Calliphora vicina and Lucilia sericata as passive vectors of Mycobacterium avium subsp. avium, M. paratuberculosis and M. a. hominissuis. Med. Vet. Entomol. 18: 116-122.

Florou, M.; Leontides, L.; Kostoulas, P.; Billinis, C.; Sofia, M.; Kyriazakis, L. y Lykotrafitis, F. (2008). Isolation of Mycobacterium avium subspecies paratuberculosis from non-ruminant wildlife living in the sheds and the pastures of Greek sheep and goats. Epidemiol. Infect. 136: 644-652.

Fodstad, F.H. y Gunnarsson, E. (1979). Postmortem examination in the diagnosis of Johne's disease in goats. Acta Vet. Scand. 20: 157-167.

Forshell, K.P. (2001). Description of paratuberculosis. International Dairy Federation, Brussels, Belgium. FIL/IDF Bull 364, 9-12.

Forthingham, R.; Strickland, P.L.; Bretzel, G.; Ramaswamy, S.; Musser, J.M. y Williams, D.L. (1999). Phenotypic and genotypic characterization of Mycobacterium africanum isolates from West Africa. J. Clin. Microbiol. 37: 1921-1926.

Francis, J. (1947). Bovine tuberculosis including a contrast with human tuberculosis. Staples Press Ltd, London.

Fujimora, Y. y Owen, R.L. (1996). Mcells as portals of infection: clinical and pathophysiological aspects. Infect. Agents Dis. 5: 144-156.

Gallagher, J. y Clifton-Hadley, R.S. (2000). Tuberculosis in badgers: a review of the disease and its significance for other animals. Res. Vet. Sci. 69(3): 203-217.

Gamboa, F.; Fernández, G.; Padilla, E.; Manterola, J.M.; Lonca, J.; Cardona, P.J.; Matas, L. y Ausina, V. (1998). Comparative evaluation of initial and new version of the Gen-Probe amplified Mycobacterium tuberculosis direct test for direct detection of Mycobacterium tuberculosis in respiratory and non-respiratory specimens. J. Clin. Microbiol. 36: 684-689.

Garbaccio, S. (2006). Diagnóstico in vivo e in vitro de la Tuberculosis Bovina. Temas de Zoonosis III. Asoc. Argen. Zoo. 25: 222-226.

García Castro, .M.C. (2007). La inspección del matadero en el diagnóstico de la tuberculosis y cisticercosis bovina. Tesis doctoral. Universidad de León, España.

García Bocanegra, I.; Barranco, I.; Rodríguez Gómez, I.M.; Pérez, B.; Gómez Laguna, J.; Rodríguez, S.; Ruiz Villamayor, E. y Perea, A. (2010). Tuberculosis in Alpacas (Lama Pacas) caused by Mycobacterium bovis. J. Clin. Microbiol. 48: 1960-1964. 
García Marín, J.F. (1991). Formas lesiónales de presentación de la tuberculosis caprina en rebaños altamente infectados. Itea EXTRA: 641-643.

García Marín, J.F. (1996). Control de la tuberculosis bovina. Tuberculosis bovina. OVIS. 46: 79-91.

García Marín, J.F.; Benazzi, S.; Pérez, V. y Badiola, J.J. (1992a). Study of entrance of M. paratuberculosis in the lamb's intestinal mucosa, using immunohistochemical methods for antigens detection. Proc. III Int. Coll. PTBC. 371-377. Orlando, E.E.U.U.

García Marín, J.F.; Chávez, G.; Adúriz, J.J.; Pérez, V.; Juste, R.A. y Badiola, J.J. (1992b). Prevalence of paratuberculosis in infected goat flocks and comparison of different methods of diagnosis. Proc. III Int. Coll. PTBC. 157-163. Orlando, E.E.U.U.

García Marín, J.F.; Pérez, V. y Badiola, J.J. (1992c). Prevalence and type of paratuberculosis lesions in sheep and their relation with the diagnosis by AGID test. En: Chiodini, R.J. y Kreeger, J.M. (Eds.). Proc $3^{\text {rd }}$ Int. Coll. PTBC. IAP. Providence. EEUU. 172-180.

García Marín, J.F.; Pérez, V.; García de Jalon, J.A.; De las Heras, M.; Barberan, M.; Fernández de Luco, D. y Badiola, J.J. (1994). Diagnóstico de casos clínicos de paratuberculosis ovina y caprina. Med. Vet. 11: 491502.

García Marín, J.F.; Tellechea, J.; Corpa, J.M.; Gutiérrez, M. y Pérez, V. (1999). Relationship between ovine paratuberculosis lesions and celular and humoral immune responses in diagnostic tests. Proc. VI Int. Coll. PTBC. 593-598. Melbourne, Australia.

García Marín, J.F.; Pérez, V. y González, J. (2000). La interacción bovino-bacteria y los mecanismos de enfermedad. En: Paratuberculosis. BOVIS. 93: 29-38.

Garrido, J.M. (2001). Puesta a punto de las técnicas de PCR en heces y de ELISA para el diagnóstico de la paratuberculosis. Estudio de prevalencia en ganado bovino. Tesis Doctoral. Universidad de Zaragoza.

Garrido, J.M.; Cortabarría, N.; Adúriz, G. y Juste, R.A. (1998). Utilización de la PCR como técnica de diagnóstico de paratuberculosis a partir de heces. Producción Ovina y Caprina. 23: 291-294.

Garrido, J.M.; Aduriz, G.; Juste, R.A. y Geijo, M.V. (2000). Los métodos de diagnóstico de la paratuberculosis en el ganado vacuno. En: Juste Editor. Paratuberculosis. BOVIS. 93: 49-61.

Garro, C.; Morris, W.; Delgado, F. y Garbaccio, S. (2011). Tuberculosis bovina en terneros. Vet. Arg. 28(276): 1-10.

Gasteiner, J.; Awad-Masalmeh, M. y Baumgartner, W. (2000). Mycobacterium avium subsp. paratuberculosis infection in cattle in Austria, diagnosis with culture, PCR and ELISA. Vet. Microbiol. 77: 339-349.

Gerlach, G.F. (2002). Paratuberculosis: the pathogen and routes of infection. Dtsch. Tierarztl. Wochenschr. 109: 504-506.

Gilardoni y Mundo, S.L. (2008). Paratuberculosis bovina. Ciencia y técnica. Infovet. 13: 11-14.

Gill, J.W. y Jackson, R. (1993). Tuberculosis in a rabbit: a case revisited. New. Zeal. Vet. J. 41: 147.

Gilmour, N.J. (1976). The pathogenesis, diagnosis and control of Johne's disease. Vet. Rec. 99: 433-434.

Gilmour, N.J.; Nisbet, D.L. y Brotherston, J.C. (1965). Experimental oral infection of calves with Mycobacterium johnei. J. Comp. Pathol. 75: 281-286. 
Gilmour, N.J. y Brotherston, J.G. (1966). Further studies on immunity to Mycobacterium johnei in sheep. Relationship between hypersensitivity and host response to infection. J. Comp. Pathol. 76: 341-349.

Gilmour, N.J.L.; Angus, K.W. y Mitchell, B. (1978). Intestinal infection and host response to oral administration of Mycobacterium johnei in sheep. Vet. Microbiol. 2: 223-235.

González, J. (2003). Caracterización lesional y evaluación de técnicas diagnósticas de la paratuberculosis bovina. Tesis doctoral. Universidad de León, España.

González, J.; Geijo, M.V.; García-Pariente, C.; Corpa, J.M.; Reyes, L.E.; Ferreras, M.C.; Juste, R.A.; García Marín, J.F. y Pérez, V. (2005). Histopathological classification of lesions associated with natural paratuberculosis infection in cattle. J. Comp. Pathol. 33: 184-196.

Goodfellow, M. y Wayne, L.G. (1982). Taxonomy and nomenclature. En: Ratledge, C. y Stanford, J. T. editors. The Biology of the Mycobacteria. Physiology, Identification and Classification. 471-521. Londres. Gran Bretaña.

Goodger, W.J.; Collins, M.T.; Norlund, K.V.; Eiselle, C.; Pelletier, J.; Thomas, C.B. y Sockett, D.C. (1996). Epidemiologic study of on-farm management practices associated with prevalence of Mycobacterium paratuberculosis infections in dairy cattle. J. Am. Vet. Assoc. 208: 1877-1881.

Gortázar, C.; Torres, M.J.; Vicente, J.; Acevedo, P.; Reglero, M.; de la Fuente, J.; Negro, J.J. y AznarMartín, J. (2008). Bovine tuberculosis in Donana Biosphere Reserve: the role of wild ungulates as disease reservoirs in the last Iberian lynx strongholds. PLoS. ONE. 3: e2776.

Gracey, J.F. (1989). Veterinary role in public health. Vet. Rec. 124(10): 257.

Grange, J.M. (2001). Mycobacterium bovis infection in human beings. Tuberculosis. 81: 71-77.

Grange, J.M.; Yates, M.D. y Boughton, E. (1990). The avian tubercle bacillus and its relatives. J. Appl. Microbiol. 68: 411-431.

Green, E.P.; Tizard, M.L.V.; Moss, M.T.; Thomposn, J.; Winterbourne, D.J.; McFadden, J.J. y HermonTaylor, J. (1989). Sequence and characteristics of IS900, an insertion element identified in a human Crhon's disease isolate of Mycobacterium paratuberculosis. Nucleic Acids Res. 17: 9063-9073.

Greig, A.; Stevenson, K.; Henderson, D.; Pérez, V.; Hughes, V.; Pavlik, I.; Hines, M.E.; McKendrick, I. y Sharp, J.M. (1999). Epidemiological study of paratuberculosis in wild rabbits in Scotland. J. Clin. Microbiol. 37: 1746-1751.

Griffin, J.F.T. y Buchan, G.S. (1993). Vaccination against tuberculosis: is BCG more sinned against than sinner? Immunol. Cell. Biol. 71: 431-442.

Griffiths, A.T.; Rioux, K. y Jeroen, B. (2008). Sequence polymorphisms in a surface PPE protein distinguish type I, II and III of Mycobacterium avium subsp. paratuberculosis.J. Clin. Microbiol. 46: 1207-1212.

Gruenendaal, H.; Nielen, M. y Hesselink, J.W. (2003). Development of the Dutch Johne's disease control program supported by a simulation model. Prev.Vet.Med., 60: 69-90.

Guanziroli, S.; Maria, C. y Maria, E. (2005). Tuberculinización en búfalos. Comunicaciones científicas y tecnológicas. http://www.unne.edu.ar/Web/cyt/com2005/4-Veterinaria/V-009.pdf.

Guilbride, P.D.L.; Rollinsin, D.H.L.; McAnulty, E.G.; Alley, J.G. y Wells, E.A. (1963). Tuberculosis in the free living African (Cape) buffalo (Syncerus caffer caffer. Sparrman). J. Comp. Path. 73: 337-348. 
Gutiérrez-Cancela, M.M. (1996). Contribución al conocimiento anatomopatológico y diagnóstico de la tuberculosis caprina y bovina por Mycobacterium bovis. Tesis doctoral. Universidad de León.

Gutiérrez-Cancela, M.M. y García Marín, J.F. (1993). Comparison of Ziehl-Neelsen staining and immunohistochemistry for the detection of Mycobacterium bovis in bovine and caprine tuberculosis lesions. $J$. Comp. Path. 109: 361-370.

Gutiérrez, M.; Tellechea, J. y García Marín, J.F. (1998). Evaluation of celular serological diagnostic tests for the detection of Mycobacterium bovis infectes goats. Vet. Microbiol. 62(4): 281-290.

Gwozdz, J.M.; Thompson, K.G.; Manktelow, B.W.; Murray, A. y West, D.M. (2000a). Vaccination against paratuberculosis of lambs already infected experimentally with Mycobacterium avium subspecies paratuberculosis. Aust. Vet. J. 78: 560-566.

Gwozdz, J.M.; Thompson, K.G.; Murray, A.; Reichel, M.P.; Manktelow, B.W. y West, D.M. (2000b). Comparison of three serological tests and an interferon-gamma assay for the diagnosis of paratuberculosis in experimentally infected sheep. Aust. Vet. J. 78: 779-783.

Haagsma, J. (1993). Bacteriology of mycobacteria, in particular the M. tuberculosis/bovis complex. En: Micobacteriosis de los animales domésticos: Tuberculosis, Paratuberculosis. Curso de post-grado de la Facultad de Veterinaria de la Universidad de Zaragoza.

Hagan, W.A. (1936). Vacunation against Johne's disease. Cornell Vet. 25: 344-353.

Haines, D.M.; Cooke, E.M. y Clark, E.G. (1987). Avidin-biotin-peroxidase complex immunohistochemistry to detect immunoglobulin in formalin fixed skin biopsies in canine autoimmune skin disease. Can. J. Vet. Res. 51: 104-109.

Haines, D.M. y Chelack, B.J. (1991). Technical considerations for developing enzyme immunohistochemical staining procedures on formalin-fixed paraffin-embedded tissues for diagnostic pathology. J. Vet. Diagn. Invest. 3: 1293-1298.

Haines, D.M. y Clarke, E.G. (1991). Enzyme immunohistochemical staining of formalin-fixed tissues for diagnosis in veterinary pathology. Can. Vet. J. 32: 295-302.

Hamilton, H.L.; Cooley, A.J.; Adams, J.L. y Czuprynski, C.J. (1991). Mycobacterium paratuberculosis monoassociated nude as a paratuberculosis model. Vet. Pathol. 28: 146-155.

Hanna, J.; Neill, S.D. y O'brien, J. J. (1989). Use of PPD and phosphatide antigens in an ELISA to detect the serological response in experimental bovine tuberculosis. Res. Vet. Sci. 47: 43-47.

Hansen, D. y Rossitier, C. (1999). Descripción clínica y epidemiológica de la enfermedad de John’́s en el ganado bovino. AMEBE, Boletín informativo. 22: 29-32.

Hardin, L.E. y Thorne, J.G. (1996). Comparison of milk with serum ELISA for the detection of paratuberculosas in dairy cows. J. Am. Vet. Med. Assoc. 209: 120-122.

Harding, H.P. (1957). Experimental infection with Mycobacterium johnei. II. The histopathology of infection in experimental goats. J. Comp. Pathol. 67: 37-52.

Haregewoin, A.; Soman, G.; Hom, R.C. y Finberg, R.W. (1989). Human gamma-delta +T cells respond to mycobacterial heat-shock protein. Nature. 340: 309-312.

Harris, N.B. y Barletta, R.G. (2001). Mycobacterium avium subsp. paratuberculosis in Veterinary Medicine. Clin. Microbiol. Reviews. 14: 489-512. 
Hein, W.R. y Tomasovic, A.A. (1981). An abattoir survey of tuberculosis in feral buffaloes. Aust. Vet. J. 57: 543-547.

Hein, W.R. y Mackay, C.R. (1991). Prominence of gamma delta T cells in the ruminant immune system. Immunol. Today. 12: 30-34.

Hermon, T.J.; Bull, T.; Sheridan, J. Cheng, J.; Stellakis, M. y Sumar, M. (2000). Causation of Crohn's disease by Mycobacterium avium subsp. paratuberculosis. . J. Can. Gastroent. 14: 521-539.

Hermoso de Mendoza, J.; Parra, A.; Tato, A.; Alonso, J.M.; Rey, J.M.; Pena, J.; García-Sánchez, A.; Larrasa, J.; Teixido, J.; Manzano, G.; Cerrato, R.; Pereira, G.; Fernández-Llario, P. y Hermoso de Mendoza, M. (2006). Ovine tuberculosis in wild boar (Sus scrofa), red deer (Cervus elaphus) and cattle (Bos taurus) in a Mediterranean ecosystem (1992-2004). Prev. Vet. Med. 74(2-3): 239-247.

Hernandéz, P.; Jeyanathan, M.; Mengistu, G.; Aguilar, D.; Orozco, H.; Harboe, M.; Rook, G.A. y Bjune, G. (2000). Persistence of DNA from Mycobacterium tuberculosis in superficially normal lung tissue during latent infection. Lancet. 356: 2133.

Hernández de Anda, J.; Rentería, T.; López, G. y Montaño, M. (1997). An abattoir monitoring system for diagnosis of tuberculosis in cattle in Baja California, México. J. Am. Vet. Med. Assoc. 211 (6): 709-711.

Hines, S.A.; Buerguelt, C.D.; Wilson, J.H. y Bliss, E.I. (1987). Disseminated Mycobacterium paratuberculosis infection in a cow. J.Am. Vet. Med. Assoc. 190: 681-683.

Hope, J.; Thom, M.; McCormick, P. y Howard, C. (2003). Interaction of antigen of bovine dendritic cells by lipopeptides. Vet. Immunol. Immnunop. 9: 21-31.

Hostetter, J.M.; Steadham, E.M.; Haynes, J.S.; Bailey, T.B. y Cheville, N.F. (2002). Cytokine effects on maturation of the phagosomes containing Mycobacterium avium subspecies paratuberculosis in $\mathrm{J} 774$ cells. FEMS Immunol. Med. Microbiol. 34: 127-134.

Huchzermeyer, H.; Brückner, G.; Van Heerden, A.; Kleeberg, H.H.; Van Rensburg, I.B.J.; Koen, P. y Loveday, R.K. (1994). Tuberculosis. Infectious diseases of livestock. Coetzer, J.A.W.; Thompson, G.R. y Tustin, R.C. (Eds.) Oxford university press. 2: 1425-1443. Oxford, Reino, Unido.

Huda, A. y Jensen, H.E. (2003). Comparison of histopathology, cultivation of tissues and rectal contents, and interferon-gamma and serum antibody responses for the diagnosis of bovine paratuberculosis. J. Comp. Pathol. 129: 259-267.

Hughes, M.S.; Skuce, R.A.; Beck, L.A. y Neill, S.D. (1993). Identification of mycobacteria from animals by restriction enzyme analysis and direct DNA cycle sequencing of polymerase chain reaction-amplified $16 \mathrm{~S}$ rRNA gene sequences. J. Clin. Microbiol. 31: 3216-3222.

Hutchinson, L.J. (1996). Economic impact of paratuberculosis. Vet. Clin. North Am. Food Anim. Pract.12 (2): $373-381$.

Hutyra, F. y Marek, J. (1930). Enteritis paratuberculosa de los bóvidos. Patología y terapéutica especiales de los animales domésticos. Ed. Revista veterinaria de España. $1^{\circ}$ ed., pp. 613-620. Barcelona, España.

Ilukevich Anerik, A. (1974). Estudio experimental sobre el diagnóstico de la tuberculosis bovina mediante pruebas de cultivo e inoculación animal. Ciencias Veterinarias. Maracaibo. 4: 137-200.

Iob, L.; Arcangeli, G.; Mutinelli, F. (1996). Utilizzo delle metodiche immunoistochimica e del test gammainterferon nella diagnosi precoce della paratuberculosi bovina. Vet. Ital. 32: 23-26. 
Jaimes, N.G.; Santillán, M.A.; Hernández, O.A.; Córdova, D.; Guzmán, C.C.; Arellano, B.; Díaz, E.; Tenorio, V.R. y Cuellar, A. (2008). Detection of Mycobacterium avium subspecies paratuberculosis by nested-PCR of ovine fecal samples. Vet. Méx. 39 (4): 377-386.

Janis, E.M.; Kaufmann, S.H.E.; Schwartz, R.H. y Pardoll, D.M. (1989). Activation of gd cells in the primary immune response to Mycobacterium tuberculosis. Science. 244: 713-716.

Jensen, K.A. (1953). Bovine tuberculosis in man and cattle. En: WHO/FAO Advances in the control of Zoonosis Geneva. Pp. 35. Citado por: Ilukevich Anerik, A. (1974). Estudio experimental sobre el diagnóstico de la tuberculosis bovina mediante pruebas de cultivo e inoculación animal. Ciencias Veterinarias. Maracaibo. 4: 137-200.

Johne, H.A. y Frothingham, L. (1895). Ein eigenthümlicher fall von tuberkulose beim rind. Dtsch. Ztschr. Tiermend. Path. 21: 438-454.

Johnson, H.W.; Larson, A.B.; Henley, R.R. y Groth, A.H. (1949). The relationship of the allergens of Mycobacterium paratuberculosis, Mycobacterium tuberculosis var. avium, bovis and hominis and Mycobacterium phlei. J. Vet. Res. 10: 138-141.

Johnson-Yfearulundu, Y.; Kaneene, J.B.; Sprecher, D.J; Gardiner, J.C. y Lloyd, J.W. (2000). The effect of subclinical Mycobacterium paratuberculosis infection on days open in Michigan, USA, dairy cows. Prev. Vet. Med. 46: 171-181.

Jones, D.G. y Kay, J.M. (1996). Serum biochemistry an the diagnosis of Johne's disease (paratuberculosis) in sheep. Vet. Rec. 139: 498-499.

Jorge, M.C.; Traversa, M.J.; Schettino, D.M.; Fresneda, K. y Mendivil, I.M. (2005). Epidemiología e importancia económica de la paratuberculosis bovina. Consultado: http:/johnes.net/general/control.html.

Jorgensen, J.B. (1969). Paratuberculosis in pigs. Experimental infection by oral administration of Mycobacterium paratuberculosis. Acta. Vet. Scand. 10: 275-287.

Jorgensen, J.B. (1972). Studies on the occurrence of paratuberculosis in cattle in Denmark. Nord. Vet. Med. 24: $297-308$.

Jorgensen, J.B. y Jensen, P.T. (1978). Enzyme-linked immunosorbent assay (ELISA) for detection of antibodies to Mycobacterium paratuberculosis in cattle. Acta. Vet. Scand. 19: 310-312.

Jubb, K.V.F.; Kennedy, P.C. y Palmer, N. (1985). Micobacterial enteriris. En: Jubb, K.V.F.; Kennedy, P.C. y Palmer, N. editores. Pathology of Domestic Animals. 155-159. London.

Julian, R.J. (1975). A short review and some observations on Johne's disease with recommendations for control. Can. Vet. J. 16: 33-43.

Juste, R.A. (1997). Johne's disease: a review of current knowledge. En: Allworth editor. Proc. $4^{\circ}$ Int. Congr. Sheep Vet., pp. 140-150. ASVS, Armidale, NSW, Australia.

Juste, R.A.; Cuervo, L.A.; Gelabert, J.L.; Sáez de Ocáriz, C.; Marco, J.C. y Camon, J. (1983). Paratuberculosis bovina en Vizcaya. Hyg. Pec. 5: 57-67.

Juste, R. A. y Adúriz, J.J. (1990a). Diagnóstico. Paratuberculosis ovina. OVIS. 7: 49-62.

Juste, R.A. y Adúriz, J.J. (1990b). Aspectos epidemiológicos. Paratuberculosis ovina. OVIS. 7: 65-75.

Juste, R.A. y Sáez de Ocáriz, C. (1990). Control. En: Juste editor. Paratuberculosis. OVIS., 77-85. Madrid. 
Juste, R.A.; Marco, J.C.; Sáez de Ocariz, C. y Adúriz, J.J. (1991). Comparison of different media for the isolation of small ruminant strains of Mycobacterium paratuberculosis. Vet. Microbiol. 28: 385-390.

Juste, R.A.; Garrido, J.M. y Adúriz, G. (2000). Paratuberculosis: El agente causal de la paratuberculosis y su situación taxonómica. Paratuberculosis. BOVIS. 93: 13-28.

Juste, R.A.; Garrido, J.M.; Geijo, M.; Elquezabal, N.; Aduriz, G.; Atzaerandio, R. y Sevilla, I. (2005). Comparison of blood polymerase chain reaction and enzyme-lynked immunosorbent assay for detection of Mycobacterium avium subsp. paratuberculosis infection in cattle and sheep. J. Vet. Diagn. Invest. 17: 354359.

Kabelitz, D.; Bender, A.; Sschouldermaier, S.; Schoel, B. y Kaufmann, S.H.E. (1990). A large fraction of human peripheral blood gamma-delta $+\mathrm{T}$ cells is activated by M. tuberculosis but not by its 65-KD heat shock proteins. J. Exp. Med. 171: 667-679.

Kalis, C.H.; Hesselink, J.W.; Russchen, E.W.; Barkerma, H.W.; Collins, M.T. y Visser, I.J. (1999). Factors influencing the isolation of Mycobacterium avium subsp. paratuberculosis from bovine fecal samples. J. Vet. Diagn. Invest. 11: 345-351.

Kalis, C.H.; Hesselink, J.W.; Barkerma, H.W. y Collins, M.T (2000). Culture of strategically pooled bovine fecal samples as a method to screen herds for paratuberculosis. J. Vet. Diagn. Invest. 12(6): 547-551.

Kalis, C.H.; Hesselink, J.W.; Barkerma, H.W. y Collins, M.T (2001). Use of long-term vaccination with a killed vaccine to prevent faecal shedding of Mycobacterium avium subsp. paratuberculosis in dairy herds. Am. J. Vet. Res. 62: 270-274.

Kalis, C.H.; Barkema, H.W.; Hesselink, J.W.; Van Maanen, C. y Collins, M.T. (2002). Evaluation of two absorbed enzyme-linked immunosorbent assays and a complement fixation test as replacements for fecal culture in the detection of cows shedding Mycobacterium avium subsp. paratuberculosis. J. Vet. Diagn. Invest. 14: 219-224.

Kalis, C.H.; Collins, M.T.; Hesselink, J.W. y Barkema, H.W. (2003). Specificity of two tests for the early diagnosis of bovine paratuberculosis based on cell-mediated immunity: the Johnin skin test and the gamma interferon assay. Vet. Microbiol. 97: 73-86.

Kantor, I.N de.; Odeón, A.C.; Steffan, P.E.; Auza, M.J.; Madrid, C.R. y Marchevsky, N. (1984). Sensivity of the cervical and the caudal fold tuberculin tests with Mycobacterium bovis in infected cattle of Argentina. Rev. sci. tech. Off. Int. Epiz. 3: 137-150.

Kaufmann, S.H.E. (1995). Immunity to intracelular microbial pathogens. Immunol. Today. 16: 338-342.

Kaur, P.; Filia, G.; Singh, S.V.; Patil, P.K. y Sandhu, K.S. (2010). Molecular detection and typing of Mycobacterium avium subspecies paratuberculosis from milk samples of dairy animals. Trop. Anim. Health Prod. 42: 1031-1035.

Kell, D.B. y Young, M. (200). Bacterial dormancy and culturability: The role of autocrine growth factors. Vet. Microbiol. 3: 228-243.

Kennedy, D.J. y Benedictus, G. (2001). Control of Mycobacterium avium subsp. paratuberculosis infection in agricultural species. Rev. Sci. Tech. 20: 151-179.

Khare, S.; Ficht, T.A.; Santos, R.L.; Romano, J.; Ficht, A.R.; Zhang, S.; Grant, I.R.; Libal, M.; Hunter, D. y Adams, L.G. (2004). Rapid and sensitive detection of Mycobacterium avium subsp. paratuberculosis in bovine milk and feces by a combination of immunomagnetic bead separation-conventional PCR and real-time PCR. J. Clin. Microbiol. 42 (3): 1075-81. 
Kheirandish, R.; Khodakaram Tafti, A. y Hosseini, A. (2008). The comparative evaluation of immunohistochemical and acid fast staining with histopathological changes in naturally occurring paratuberculosis in sheep. Comp. CLin. Pathol. 17: 111-116.

Kimberling, C.V. (1988). Paratuberculosis. Lea y Febiger editors. Jensen \& Swifts disease of sheep. 235238. Filadelfia, USA.

Koets, A.P.: Adugna, G.; Janss, L.L.; Van Weering, H.J.; Kalis, C.H.; Wentink, G.H.; Rutten, V.P. y Schukken, Y.H. (2000a). Genetic variation of susceptibility to Mycobacterium avium subsp. paratuberculosis infection in dairy cattle. J. Dairy Sci. 83: 2702-2708.

Koets, A.P.; Rutten, V.P.; Bakker, D.; Van Der Hage, M.H. y Van Eden, W. (2000b). Lewis rats are not susceptible to oral infection with Mycobacterium avium subsp. paratuberculosis. Vet. Microbiol. 77: 487-495.

Kohler, H.; Gyra, H.; Zimmer, K.; Dräger, K.G.; Burkert, B.; Lemser, B.; Hausleithner, D.; Cubler, K.; Klawonn, W. y Hess, R.G. (2001). Immune reactions in cattle after immunization with a Mycobacteium paratuberculosis vaccine and implications for the diagnosis of $M$. paratuberculosis and $M$. bovis infections. $J$. Vet. Med. B. Infect. Dis. Vet. Public. Health. 48: 185-195.

Koniha, L.D.; Himes, E.M. y Thoen, C.O. (1980). Bovine tuberculosis. En: Handbook Series in Zoonoses. Steele, J.H.; Stoenner, H. y Kaplan, W. eds. CRC Press, Boca Raton, Florida, USA.

Kramsky, J.A.; Miller, D.S.; Hope, A. y Collins, M.T. (2000). Modification of bovine ELISA to detect camelid antibodies to Mycobacterium paratuberculosis. Vet. Microbiol. 77: 333-337.

Kreeger, J.M. (1991). Ruminant paratuberculosis a century of progress and frustration. J. Vet. Diagn. Invest. 3: 373-383.

Kremer, K.; Van Sooligen, D.; Van Embden, J.; Hughes, S.; Inwald, J. y Hewinson, G. (1998). Mycobacterium microti: more widespread than previously thought. J. Clin. Microbiol. 36: 2793-4.

Kruze, J.; Salgado, M. y Collins, M.T. (2007). Paratuberculosis en rebaños caprinos chilenos. Arch. Med. Vet. 39: $147-152$.

Kubabara, S. (1975a). Purification and properties of tuberculin active protein from Mycobacterium tuberculosis. J. Biol. Chem. 250: 2556.

Kubabara, S. (1975b). Aminoacid sequence of tuberculin active protein from Mycobacterium tuberculosis. . Biol. Chem. 250: 2563.

Kuehnel, M.P.; Goethe, R.; Habermann, A.; Mueller, E.; Rohde, M.; Griffiths, G. y Valentine-Weigand, P. (2001). Characterization of the intracellular survival of Mycobacterium avium ssp. paratuberculosis: phagosomal $\mathrm{pH}$ and fusogenicity in $\mathbf{J} 774$ macrophages compared with other micobacteria. Cell. Microbiol. 3: 551-566.

Kurade, N.P.; Tripathi, B.N.; Rajukumar, K. y Parihar, N.S. (2004). Sequential development of histologic lesions and their relationship with bacterial isolation, fecal shedding, and immune responses during progressive stages of experimental infection of lambs with Mycobacterium avium subsp. paratuberculosis. Vet. Pathol. 41: 378-387.

Lagadic, M.; Le Menec, M.; Argente, G.; Lecoz, N.; Massart, M.T.; Moisan, J. y Quiniou, M.A. (1983). Techniques de cultures de Mycobacterium paratuberculosis: Leur utlisation en routine dans un laboratoire de diagnostic. Rec. Med. Vet. 159: 801-807.

Larsen, A.B.; Baisden, L.A.; Merkal, R.S. y Morris, M.J. (1957). Methods of injecting tuberculin in cattle. Am. J. Vet. Res. 18: 546-549. 
Larsen, A.B. (1964). Recent developments in paratuberculosas (Johne's disease) research. Proc. Annu. Meet. U.S. Anim. Health Assoc. 68: 342-347.

Larsen, A.B.; Merkal, R.S.; Kopecky, K.E. y Boothe, A.D. (1969). Hipersensitivity and serologic responses in cattle vaccinated with disrupted Mycobacterium paratuberculosas cells and subsequently infected with Mycobacterium bovis. Am. J. Vet. Res. 30: 2167-2172.

Larsen, A.B.; Moon, H.W. y Merkal, R.S. (1971). Susceptibility of swine to Mycobacterium paratuberculosis. Am. J. Vet. Res. 32: 589-595.

Larsen, A.B.; Moon, H.W. y Merkal, R.S. (1972). Susceptibility of horse to Mycobacterium paratuberculosis. Am. J. Vet. Res. 33: 2185-2189.

Larsen, A.B.; Merkal, R.S. y Moon, H.W. (1974). Evaluation of a paratuberculosas vaccine given to calves before infection. Am. J. Vet. Res. 35: 367-369.

Larsen, A.B.; Merkal, R.S. y Cutlip, R.C. (1975). Age of cattle as related to resistance to infection with Mycobacterium paratuberculosis. Am. J. Vet. Res. 36: 255-257.

Larsen, A.B.; Moyle, A.I. y Himes, E.M. (1978). Experimental vaccination of cattle against paratuberculosis (Johne's disease) with killed bacterial vaccines: a controlled field study. Am. J. Vet. Res. 39: 65-69.

Larsen, A.B.; Stalheim, O.H.V.; Hughes, D.E.; Appell, L.H.; Richards, W.D. y Himes, E.M. (1981). Mycobacterium paratuberculosis in the semen and genital organs of a semen-donor bull. JAVMA. 179: 169171.

Lawrence, W.E. (1956). Congenital infection with Mycobacterium johnei in cattle. Vet. Rec. 68: 312-314.

Leid, J.G.; Hunter, D. y Speer, C.A. (2002). Early diagnosis of Johne's disease in the American bison by monoclonal antibodies directed against antigen 85. Ann. N. Y. Acad. Sci. 969: 66-72.

Levy-Frebault, V.V. y Portaels, F. (1992). Porposed minimal standards for the Mycobacterium and for description of new slowly growing Mycobacterium species. Int. Syst. Bacteriol. 42: 315-323.

Liying, L.; Brandon, L.; Plattner, M. y Hostetter, M. (2008). Live Mycobacterium avium subsp. paratuberculosis and a killed-bacterium vaccine induce distinct subcutaneous granulomas, with unique cellular and cytokine profiles. Clin. Vacc. Immunol. 15: 783-793.

López, G.; Hernández de Anda, J. y Sierra, E. (1997). Diagnóstico postmortem en decomisos sugestivos a tuberculosis en ganado bovino sacrificado en rastros en Baja California. Vet. Méx. 28 (3): 235-239.

López, L.M.; Díaz, F.; Valecillo A.J.; Esquivel, H. y Gutiérrez, J.A. (2006).Tuberculosis humana y bovina en Latinoamérica: De estudios sobre virulencia hacia herramientas para su control. Rev. Latinoa. Microbiol. 48: 173-178.

López-Garrido, L.A. (2008). Diagnóstico molecular de Mycobacterium avium subespecie paratuberculosis en ganado bovino de la zona centro del Estado de Veracruz. Tesis de Licenciatura. FMVZ. Universidad Veracruzana.

Losinger, W.C. (2005). Economic impact of reduce milk production associates with Johne's disease on dairy operations in the USA. J. Dairy Res. 72: 425-432.

Lugton, I. (1999). Mucosa-associated lymphoid tissues as sites for uptake, carriage and excretion of tubercle bacilli and other pathogenic micobacteria. Immunol. Cell. Biol. 77: 364-372.

Luke, D. (1958). Tuberculosis in the horse, pig, sheep and goat. Vet. Rec. 70: 528-536. 
Lyashchenko, K.; Manca, C.; Colangeli, R.; Heijbel, A.; Williams, A. y Gennaro, M. (1998). Use of Mycobacterium tuberculosis complex-specific antigen cocktails for a skin test specific for tuberculosis. Infect. Immun. 66: 3606-10.

Lyle, P.A.S. y Merkal, R.S. (1983). Comparison of ELISA and gel diffusion precipitin test for paratuberculosis in cattle, sheep and goats. Proc. I. Int. Coll. PTBC. 109-112. Ames, E.E.U.U.

Maartens, G. y Wilkinson, R.J. (2007). Tuberculosis. Lancet. 370: 2030-2043.

Mackintosh, C.G.; Haigh, J.C. y Griffin, F. (2002). Bacterial diseases of farmed deer and bison. Rev. Sci. Tech. 21: 249-263.

Magnano, G.G.; Schenider, M.O.; Urbani, C.E.; Ambrogi, A.; Zapata, L. y Jorge, M.C. (2010). Comparación de técnicas diagnósticas de tuberculosis porcina en dos establecimientos de cría confinada en Argentina. Infovet. 12: 25-31.

Manning, E.J.B. y Collins, M.T. (2001). Infecciones micobacterianas en animales domésticos y salvajes. Rev. Cient. y Téc. de la Oficina Internacional de Epizootias. 20.

Mantilla, J.B. (2007). Estudio histopatológico de ganglios linfáticos de bovinos positivos a la prueba de tuberculina, procesados en laboratorios de SENASA, Lima, procedentes de las Regiones de Piura, Lambayeque, La Libertad y Lima (1997-2003).

Marco, I.; Ruiz, M.; Juste, R.; Garrido, J.M. y Lavin, S. (2002). Paratuberculosis in free-reanging fallow deer in Spain. J. Wildl. Dis. 38: 629-632.

Marco, J.C. y Adúriz, J.J. (1990). Sobre Mycobacterium paratuberculosis. En: Juste, R. A. OVIS. Paratuberculosis. 9-23. Madrid.

Mariano, M. y Spector, W.G. (1973). The formation and properties of macrophage polykaryons (inflammatory giant cells). J. Path. 113: 1-19.

Martínez-Vidal, C.A. (2008). Diagnóstico molecular de Mycobacterium bovis en ganado bovino de la zona centro del Estado de Veracruz. Tesis de Licenciatura. FMVZ, Universidad Veracruzana.

Mason, O.; Marsh, I. y Whittington, R.J. (2001). Comparison of immunomagnetic bead separationpolymerase chain reaction and faecal culture for the detection of Mycobacterium avium subsp. paratuberculosis in sheep faeces. Aust. Vet. J. 79: 497-500.

McDonald, W.L.; Ridge, S.E; Hope, A.F. y Condron, R.J. (1999). Evaluation of diagnostic test for Johne's disease in young cattle. J. Aust. Vet. 77: 113-119.

McPherron, T.A.; Coglianese, C.L.; Jaster, E.H.; Urbance, J.W.; Mock, R.E.; Oetzer, G.R. y Parre, M. (1983). Observations on the economic impact of Johne's disease (Paratuberculosis) on cattle herds in Illinois. Proc. I Int. Coll. PTBC. 55: 246-251.

Merck Veterinary Manual. (2008). Introducción de la paratuberculosis. En línea consultado: 18 de febrero del 2011. http:/www.merckvetmanual.com/mvm/index.jsp?cfile=htm/bc/55900.Htm\&word=paratuberculosis.

Menchen Ozaita, V. (1995). Estudio inmunocitoquímico de la tuberculosis y paratuberculosis caprina. Tesis doctoral. Universidad de Murcia.

Merkal, R.S. (1973). Laboratory diagnosis of bovine paratuberculosis. J. Am. Vet. Med. Assoc. 163: 11001102. 
Merkal, R.S. (1984). Paratuberculosis: advances in cultural, serologic, and vaccination methods. J. Am. Vet. Med. Assoc. 184: 939-943.

Merkal, R.S.; Larsen, A.B.; Velicer, L.F. y Thurston, J.R. (1965). Serologic and allergenic effects of 3 Mycobacterium paratuberculosis antigens. Am. J. Vet. Res. 26: 1267-1270.

Merkal, R.S.; Larsen, A.B. y Booth, G.D. (1975). Analysis of the effects of inapparent bovine paratuberculosis. Am. J. Vet. Res. 31: 837-838.

Merkal, R.S.; Whipple, D.L.; Sacks, J.M. y Synder, G.R. (1987). Prevalence of Mycobacterium paratuberculosis in ileocecal lymph nodes of cattle culles in the United States. JAVMA. 190: 676-680.

Michel, A.L. (2002). Implications of tuberculosis in African wildlife and livestock. Ann. N. Y. Acad. Sci. 969: 251-255.

Michel, A.L.; Bengis, R.G.; Keet, D.F.; Hofmeyr, M.; Klerk, L.M.; Cross, P.C.; Jolles, A.E.; Cooper, D.; Whyte, I.J; Buss, P. y Godfroid, J. (2006). Wildlife tuberculosis in South African conservation áreas: implications and challenges. Vet. Microbiol. 112: 91-100.

Michel, A.L.; Müller, B. y Van Helden, P.D. (2010). Mycobacterium bovis at the animal -human interface: A problem, or not?. Veterinary Microbiology. 140: 371-381.

Milian Suazo, F.; Salman, M.D.; Ramírez, C.; Payeur, J.B.; Rhyan, J.C. y Santillán, M. (2000). Identification of tuberculosis in cattle slaugthered in México. American Journal of Veterinary Research. 61: 86-89.

Milian Suazo, F.; García, C.L.; Romero, T.C.; Cantó, A.G.J.; Gutierréz, R.J.A.; Gallegos, S.S.; Mercado, P.M.; Mejía, E.F.F.; Peña, C.A.L.; Estrada, C.C. y Pizano, M.O. (2012). Diversidad genetica y distribución regional de cepas de Mycobacterium bovis del gando en México. Rev. Mex. Cienc. Pecu. 3(4): 459-471.

Millar, D.; Ford, J.; Sanderson, J.; Withey, S.; Tizard, M.; Doran, T. y Hermon-Taylor, J. (1996). IS900 PCR to detect Mycobacterium paratuberculosis in retail supplies of whole pasteurized cows milk in England and Wales. Appl. Environ. Microbiol. 62: 3446-3452.

Miller, J.M.; Jenny, A.L.; Rhyan, J.; Saari, D. y Suarez, D. (1997). Detection of Mycobacterium bovis in formalin-fixed, paraffin-embedded tissues of cattle and elk by PCR amplification of an IS6110 sequence specific for Mycobacterium tuberculosis complex organisms. J. Vet. Diagn. Invest. 9: 244-249.

Miller, J.M.; Jenny, A.L. y Payeur, J.B. (1999). Polymerase chain reaction of Mycobacterium avium organisms in formalin-fixed tissues from culture-negative ruminants. Vet. Microbiol. 87: 15-23.

Miller, J.M.; Collins, M.T.; Smith, B.B.; Anderson, P.R.; Kramsky, J.; Wilder, G. y Hope, A. (2000). Specificity of four serologic assays for Mycobacterium avium ssp. paratuberculosis in llamas and alpacas: a single herd study. J. Vet. Diagn. Invest. 12: 345-353.

Miller, J.M.; Jenny, A.L. y Payeur, J.B. (2002). Polymerase chain reaction detection of Mycobacterium tuberculosis complex and Mycobacterium avium organisms in formalin-fixed tissues from culture-negative ruminants. Vet. Microbiol. 87: 15-23.

Milner, A.R; Mack, W.N. y Coates, K.J. (1989). A modified ELISA for the detection of goats infected with Mycobacterium paratuberculosis. J. Austr. Vet. 66: 305-307.

Miltgen, J.M.; Morillon, M.; Koeck, J.L.; Varnerot, A.; Briant, J.F. y Nguyen, G. (2002). Two cases of pulmonary tuberculosis are caused by Mycobacterium subsp. cannetti. Emerg. Infect. Dis. 8: 1350-1352. 
Miranda, B.M.V. (2005). Evaluación del impacto económico de la paratuberculosis en ganado lechero (sistema intensivo) del complejo agropecuario industrial, Tizayuca, Hidalgo, México. Tesis de Maestría FMVZ UNAM.

Mirsky, M.L.; Morton, D.; Piehl, J.W. y Gelberg, H. (1992). Mycobacterium bovis infection in a captive herd of sika deer. J. Am. Vet. Med. Assoc. 200: 1540-1542.

Momotami, E. y Yoshino, T. (1985). Caseous granulomas in bovine paratuberculosis. Inp. J. Vet. Sci. 47: 487-491.

Mohamed Anciones, Y.; Fernández, M. y Pérez, V. (2013). Estudio de la prevalencia de la aratuberculosis bovina en dos rebaños lecheros mediante métodos inmunológicos. Libro de Resumenes del XVIII. Congreso de ANEMBE, Lleida, España, Abril de 2013. Pp. 179-181.

Momotami, E.; Whipple, D.L.; Thiermann, A.B. y Cheville, N.F. (1988). Role of M cells and macrophages in the entrance of Mycobacterium paratuberculosis into domes of ileal Peyer's patches in calves. Vet. Pathol. 25: 623-627.

Monaghan, M.L.; Doherty, M.L.; Collins, J.D.; Kazda; J.F. y Quinn, P.J. (1994). The tuberculin test. Vet. Microbiol. 40: 111-124.

Morales, A.; Martínez, I.; Carlos, A.; Álvarez, G.; Álvarez, M y Maldonado, J. (2005). Comparación de histopatología, cultivo y PCR en el diagnóstico de tuberculosis bovina. Rev. Cient. FCV-LUZ. 15(2): 103-108.

Morales, A.; Peñuelas, K.; Álvares, G.; Martínez, J.; Mendoza, G y Milián Suazo, F. (2008). Correlación entre PCR en exudado nasal y la reacción de tuberculina para la detección de organismo del complejo Mycobacterium tuberculosis en bovino. Rev. Cient. FCV-LUZ. 18(1): 17-21.

Morán, M.C.; Aceves, D.; Peña, P.M.; Gallegos, M.P.; Flores, S.E.; Montoya, H.; Figueroa, L.E.; Villa, L. y Sánchez, J. (2000). Detección de Mycobacterium tuberculosis mediante la reacción en cadena de la polimerasa en una población seleccionada del noroccidente de México. Pan. Am. J. Public. Health. 7 (6): 389-394.

Moreno, B.; Adúriz, G.; Garrido, J.; Sevilla, I. y Juste, R. (2007). Disseminated Mycobacterium avium subsp. avium infection in a pet Korean squirrel (Sciuris Vulgaris Koreae). Vet. Pathol. 44: 123-125.

Moreno, O.; Ferreras, M.C; García-Pariente, C.; Fuertes, M.; Reyes, L.E.; González, J.; Muñoz, M.; Pérez, V. y García Marín, J.F. (2008). Diagnóstico de paratuberculosis en terneros sacrificados en matadero. Boletín ANEMBE. 76:9-11.

Morris, A.; Reller, L. y Devlin, B. (1994). Clinical usefulness of detecting growth of Mycobacterium tuberculosis in positive Bactec phials using PCR. Am. J. Med.Sci. 307(2): 119-127.

Morris, R.S. y Pfeiffer, D.U. (1995). Directions and issues in bovine tuberculosis epidemiology and control in New Zealand. N. Z. Vet. J. 43: 256-265.

Morrison, W.I.; Bourne, F.J.; Cox, D.R.; Donelly, C.A.; Gettinby, G.; McInerney, J.P. y Woodroffe, R. (2000). Pathogenesis and diagnosis of infections with Mycobacterium bovis in cattle. The Veterinary Record. 146: $236-242$.

Moussú, G. y Mantoux, C. (1908). Compt. Rend. Acad. d. sc. 147: 502-504. Citado por: Feldman, W.H. Y Fitch, C.P. (1936). Histologic features of the intradermic reaction to tuberculin in cattle. Arch. Pathol. 22: 495-509. 
Mouriño, M.; Oracau, A.; Jané, R.; Escribano, M.; Caylá, J.A.; Solé, N.; del Baño, L.; Quintero, S.; Ferrer, M.D.; Mangues, J.; Guerrero, R.A. y Martín, V. (2011). Concordancia de las pruebas de tuberculina e interferón gamma en población reclusa. Rev. Esp. Sanid. Penit. 13: 15-20.

Muirhead, R.H.; Gallagher, J. y Burn, K.J. (1974). Tuberculosis in wild badgers in Gloucestershire: epidemiology. Veterinary Record. 95: 552-555.

Mura, M.; Bull, J.; Evans, H.; Boumedine, S.; McMinn, L.; Rhodes, G.; Pickup, R. y Taylor. (2006). Replication and Long-term persistence of bovine and human strains of Mycobacterium avium subsp. paratuberculosis within Acanthamoeba polyphaga. applied and environmental microbiology. 72: 854-859.

Muskens, J.; Bakker, D.; De Boer, J. y Keulen, L. (2000). Paratuberculosis infection in sheep of farms with paratuberculosis infected cattle in the Netherlands. Proc. VI Int. Coll. PTBC. 213: Melbourne, Australia.

Muskens, J.; Mars, M.H.; Elbers, A.R.; Van Maanen, K. y Bakker, D. (2003). The results of using faecal culture as confirmation test of paratuberculosis-seropositive dairy cattle. J. Vet. Med. B. Infect. Dis. Vet. Public Health. 50: 231-234.

Nain, S.P.S.; Chandiramani, N.K.; Kulsheshtha, R.C. y Chugh, S.K. (1985). Studies on tuberculine and johnin reactors- a preliminary report. Indian. J. Vet. 62: 643-646.

Naranjo, V.; Gortazar, C.; Vicente, J. y de la Fuente, J. (2008). Evidence of the role of European wild boar as a reservoir of Mycobacterium tuberculosis complex. Vet. Microbiol. 127: 1-9.

Nebbia, P.; Robino, P.; Ferroglio, E.; Rossi, L.; Meneguz, G. y Rosati, S. (2000). Paratuberculosis in red deer (Cervus elaphus hippelaphus) in the western Alps. Vet. Res. Commun. 24: 435-443.

Neil, S.D. y Pollock, M. (2000). Testing for bovine tuberculosis: more than skin test. Vet. J. 160: 3-5.

Nieberle, K. (1931). Ergeb. Allg. Path. Anat. 25: 631. Citado por: Jensen, R. y Mackey, D.R. (1979). Diseases of feedlot cattle. 3rd. ed. Lea \& Febiger, Philadelphia.

Nieberle, K. y Cohrs, P. (1966). Tuberculosis. En: Textbook of the special pathological anatomy of domestic animals. Londres, Reino Unido.

Nielsen, S.S.; Kolmos, B. y Christoffersen, A.B. (2004). Comparison of contamination and growth of Mycobacterium avium subsp. paratuberculosis on two different media. J. Appl. Microbiol. 96: 149-153.

Nordlund, K.V.; Goodger, W.J.; Pelletier, J. y Collins, M.T. (1996). Associations between subclinical paratuberculosis and milk production, milk components, and somatic cell counts in dairy herds. J. Am. Vet. Med. Asoc. 208: 1872-1876.

NORMA Oficial Mexicana NOM-006-SSA2-1993, Para la prevención y control de la tuberculosis en la atención primaria a la salud.

NORMA Oficial Mexicana NOM-031-ZOO-1995, Campaña Nacional Contra la Tuberculosis Bovina.

NORMA Oficial Mexicana NOM-194-SSA2-2004, Productos y servicios. Especificaciones sanitarias en los establecimientos dedicados al sacrificio y faenado de animales para abasto, almacenamiento, transporte y expendio. Especificaciones sanitarias de producto.

Office International des Epizooties. (2009). Bovine tuberculosis. Manual of diagnostic tests and vaccine for terrestial animals. 1-16.

Oliveira, P.R.; Reis, D.O.; Coelho, H.E.; Lúcio, W.F. y Barbosa, F.C. (1986). Prevalencia da tuberculose em caracas e vísceras de bovinos abatidos em Uberlandia. Arq. Bras. Med. Vet. Zoot. 38 (6): 965-971. 
Oliveira, P.R. de Ribeiro, S.C. DE A.; García, C.A. y Reis, D. de O. (1999). Bioscience Journal. 15: 39-48.

Olsen, I.; Tryland, M.; Wiker, H.G. y Reitan, L.G. (2001). Elevated antibody responses in patients with Chron's disease against a $14-\mathrm{kDa}$ secreted protein purified from Mycobacterium avium subsp. Paratuberculosis. Scand. J. Immunol. 53: 198-203.

Olsen, I.; Sigurdardóttir, G. y Djonne, B. (2002). Paratuberculosis with special reference to cattle. A review. Vet. Q. 24: $12-28$.

O'Reilly, L.M. (1969). Tuberculosis eradication- some problems of the post attestation era. Irish Vet. J. 23: 140-148.

O'Reilly, L.M (1993a). The epidemiology of Mycobacterium bovis infections in animals and man. En: "Micobacteriosis de los animales domésticos: Tuberculosis, Paratuberculosis" Curso de post-grado de la Facultad de Veterinaria de la Universidad de Zaragoza.

O'Reilly, L.M. (1993b). Specify and sensitivity of tuberculin tests: a review. En: Micobacteriosis de los animales domésticos: Tuberculosis, Paratuberculosis. Curso de post-grado de la Facultad de Veterinaria de la Universidad de Zaragoza.

O'Reilly, L.M. y Daborn, C.J. (1995). The epidemiology of Mycobacterium bovis infections in animals and man: a review. Tubercle and Lung Disease. 6: 1-46.

Outteridge, P.M. y Lepper, A.W.D. (1973). The detection of tuberculin-sensitive lymphocytes from bovine blood by uptake of radio-labelled nucleosides. Res. Vet. Sci. 14: 296-305.

Ott, S.L.; Wells, S.J. y Wagner, B.A. (1999). Herd-level economic losses associated with Johne's disease on US dairy operations. Prev. Vet. Med. 40: 179-192.

Ozbek, A.; Michel, F.C.; Strother, M.; Motiwala, A.S.; Byrum, B.R.; Shulaw, W.P.; Thornton, C.G. y Sreevatsan, S. (2003).Evaluation of two recovery methods for detection of Mycobacterium avium subsp. paratuberculosis by PCR: direct-dilution-centrifugation and C (18)- carboxypropylbetaine processing. FEMS Microbiol. Lett. 229: 145-151.

Pak, S.L.; Kim, D. y Salman, M. (2003). Estimation of paratuberculosis prevalence in dairy cattle in a province of Korea using an enzyme-linked immunosorbent assay: application of Bayesian approach. $J$. Vet. Sci. 4: 51-56.

Paling, R.W. Waghela, S.; Macowan, K..J. y Heath, B.R. (1988). The occurrence of infectious diseases in mixed farming of domesticated wild hervibores and livestock in Kenia. II. Bacterial diseases. J. Wildl. Dis. 24: 308-316.

Pallaske, G. (1962). Die Tuberkullose deer lunge. En: "Handbuch der spesiellen Pathologischen Anatomie der Haustiere" (E. Joest, ed.). pp. 238276. Verlag Paul Parey, Berlin.

Palmer, M.V. (2007). Tuberculosis: a reemerging disease at the interface of domestic animals and wildlife. Curr. Top. Microbiol. Immunol. 315: 195-215.

Paolicchi, F.A.; Zumarraga, M.J.; Gioffre, A.; Zamorano, P.; Morsella, C. Verna, A. y Cataldi, A. (2003). Application of different methods for the diagnosis of paratuberculosis in a dairy cattle herd in Argentina. $J$. Vet. Med. 50: 20-26.

Parish, T. y Stoker, D.G. (1998). Methods in molecular biology. Micobacteria protocols. New Jersey. Pp. 358-371. 
Parra, A.; García, A.; Inglis, N.F.; Tato, A.; Alonso, J.M.; Hermoso de Mendoza, M.; Hermoso de Mendoza, J. y Larrasa, J. (2006). An epidemiological evaluation of Mycobacterium bovis infections in wild game animals of the Spanish Mediterranean ecosystem. Res. Vet. Sci. 80: 140-146.

Pavlík, I.; Veselý, T.; Bartl, J.; Horvathova, A.; Martlová, L.; Vrbas, V.; Valent, L.; Miskovic, P. y Hirko, M. (1999). Reability of diagnosis methods (clinical examination, faecal culture, skin and serological test) for paratuberculosis of cattle and sheep during the 1988-1998 eradication an control programme. Proc. VI Int. Coll. PTBC. 371-383. Melbourne, Australia.

Pavlík, I.; Rozsypalová, Z.; Veselý, T.; Bartl, J.; Martlová, L.; Vrbas, V.; Valent, L.; Rajský, D.; Mracko, I.; Hirko, M. y Miskovic, P. (2000). Control of paratuberculosis in five cattle farms by serological test and faecal culture during the period 1990-1999. Vet. Med.-Czech. 45: 61-70.

Payeur, B.; Jarnagin, L.; Marquardt, G.; Sharper, A. y Martin, M. (1993). Manual of laboratory methods in veterinary. Micobacteriology for the isolation and identification of Mycobacteria. Aes, Iowa. Departament of Agriculture, animal and plant health inspection service. Veterinary services.

Payne, J.M. y Rankin, J.D. (1961a). A comparison of the pathogenesis of experimental Johne's disease in calves and cows. Res. Vet. Sci. 2: 175-179.

Payne, J.M. y Rankin, J.D. (1961b). The pathogenesis of experimental Johne's disease in calves. Res. Vet. Sci. 2: 167-174.

Pearson, J.K.L. y McCelland, T.G. (1955). Uterine infection and congenital Johne's disease in cattle. Vet. Rec. 67: 615-616.

Pérez-Arellano, J.L.; Sánz, O.; Hernández- Cabrera, M. y Moreno- Maroto, A.A. (2005). Situación actual y perspectivas clínicas de la tuberculosis. Problemas terapéuticos. Enf. Emerg. 1: 6-11.

Pérez-Guerrero, L.; Milián-Suazo, F.; Arriaga-Díaz, C.; Romero-Torres, C. y Escartín-Chávez, M. (2008). Epidemiología molecular de las tuberculosis bovina y humana en una zona endémica de Querétaro, México. Salud Pub. Méx. 50: 286-291.

Pérez, V.; García Marín. J.F.; Peris, B.; Badiola, J.J. y Juste, R.A. (1990). Detección de M. paratuberculosis en secciones de tejido mediante la técnica de Avidina-Biotina-Peroxidasa. Estudio comparativo con la técnica de Ziehl-Neelsen. Informes técnicos de Departamento de Agricultura y Pesca del Gobierno del País Vasco, $n^{\circ} 34: 30-34$.

Pérez, V.; Bolea, R.; Chávez, G.; Cortabarría, N.; Juste, R.A.; Badiola, J.J. y García Marín, J.F. (1994a). Efficiency of PCR and culture in the detection of Mycobacterium avium subsp. silvaticum and Mycobacterium avium subsp. paratuberculosis in tissue samples of sheep. En: Chiodini, R.J.; Collins, M.T: Bassey, E.O.E. (Eds.). Proc $4^{\text {th }}$ Int. Coll. PTBC. IAP. Providence. EEUU. 97-100.

Pérez, V.; Chávez, G.; Gutiérrez, M.; Tellechea, J.; Badiola, J.J. y García Marín, J.F. (1994b). Evaluation of the AGID and $\gamma$-interferon test in lambs infected with Mycobacterium avium subsp. silvaticum and Mycobacterium avium subsp. paratuberculosis. En: Chiodini, R.J.; Collins, M.T: Bassey, E.O.E. (Eds.). Proc $4^{\text {th }}$ Int. Coll. PTBC. IAP. Providence. EEUU: 91-95.

Pérez, V.; García Marín, J.F. y Badiola, J.J. (1996). Description and classification of different types of lesion associated with natural paratuberculosis infection in sheep. J. Comp. Path. 114: 107-122.

Pérez, V.; Tellechea, J.; Badiola, J.J.; Gutiérrez, M. y García Marín, J.F. (1997). Relation between serologic response and pathologic findings in sheep with naturally acquired paratuberculosis. Am. J. Vet. Res. 58: 799803. 
Pérez, V.; Tellechea, J.; Corpa, J.M.; Gutiérrez, M. y García Marín, J.F. (1999). Relations between pathologic findings and cellular immune responses in sheep with naturally acquired paratuberculosis. Am. J. Vet. Res. 60: 123-127.

Pérez, V.; Corpa, J.M. y García Marín. J.F. (2000). El cuadro clínico y lesional de la paratuberculosis bovina. Paratuberculosis BOVIS. 93: 39-47.

Pérez, V.; Moreno, O.; Muñoz, M.; García-Pariente, C.; Benavides, J.; Delgado, L.; González, J.; Mencía, L.; Fuertes, M.; García-Marín, J.F. y Ferreras, M.C. (2009). Diagnosis of paratuberculosis in slaughtered calves in the northwest of Castilla y León (Spain) by pathological methods. $10^{\text {th }}$ International colloquium on paratuberculosis. Minnepolis, Minnesota, EEUU.

Peris, B. (1992). Contribución al conocimiento de los aspectos inmunopatológicos de la paratuberculosis ovina mediante el estudio de la respuesta humoral y celular local. Tesis Doctoral. Universidad de Zaragoza.

Persing, D.H. (1993). In vitro nucleic acid amplification. En: Diagnostic molecular microbiology: principles and applications. Am. Soc. Microbiol. 51-87. Washington D.C.

Pfeiffer, D.U. y Morris, R.S. (1991). A longitudinal study of bovine tuberculosis in possums and cattle. En: "Symposium on Tuberculosis" (Publication No. 132). Veterinary Continuing Education, Palmertson North N.Z. pp 17-39. Citado por: Morris, R.S., Pfeiffer, D.U. y Jackson, R. (1994). The epidemiology of Mycobacterium bovis infections. Vet. Microbiol. 40: 153-177.

Pillai, S.R.; Jayarao, B.M.; Gummo, J.D.; Hue, E.C.; Tiwari, D.; Stabel, J.R. y Whitlock, R.H. (2001). Identification and sub-typing of Mycobacterium avium subsp. avium by randomly amplified polymorphic DNA. Vet. Microbiol. 79: 275-284.

Plante, Y.; Remenda, B.W.; Chelack, B.J. y Haines, D.M. (1996). Detection of Mycobacterium paratuberculosis in formalin-fixed paraffin-embedded tissues by the polymerase chain reaction. Can. J. Vet. Res. 60: 115-120.

Pollock, J.M.; Rodgers, J.D.; Welsh, M.D. y McNair, J. (2006). Pathogenesis of bovine tuberculosis: the role of experimental models of infection. Vet. Microbiol. 120: 141-150.

Potel, K. (1974). La inflamación. En: Tratado de anatomía patológica general veterinaria. Acribia. 221-272. Zaragoza, España.

Poumián, A.M. (2000). La tuberculosis bovina como zoonosis. Boletines del sistema nacional de vigilancia epidemiológica, SSA.

Portilla, M.M.E. (2007). Uso de la secuencia de inserción RvD1 para la identificación de M. bovis. Tesis de Maestria. FMVZ. Universidad Veracruzana.

Pradenas, M.; Kruze, J. y Schaik, G. (2008). Sensibilidad del cultivo de pool fecal para detectar infección por Mycobacterium avium sub. paratuberculosis en rebaños bovinos de leche y su relación con la prueba de ELISA. Arch. Med. Vet. 40, 31-37.

Prat, A.C.; Domínguez, B.J. y Auxina, R.B. (consult.2010). Mycobacterium bovis. En línea consultada: abril del 2010. http://www.seimc.org/control/revi_micobac/pdf/Mbovis.

Pritchard, D.G. (1988). A century of Bovine Tuberculosis 1888-1988: Conquest and Controversy. J. Comp. Pathol. 99: 357-398.

Radostits, O.M.; Blood, D.C. y Gay, C.C. (1994). Veterinary Medicine, $3^{\mathrm{a}}$ ed. Bailliére Tindall. London. 
Raizman, E.A.; Wells, S.J.; Godden, M.; Fetrow, J.; Friendshuh, K. y Oakes, J. (2004). Characterization of Minessota dairy herds participating in a John's disease control program and evaluation of the program risk assessment tool. En línea consultado: el 13 de septiembre del 2011. www.elsevier.com/locate/prevetmet.

Raizman, E.A.; Fetrow, J.P. y Wells, S.J. (2009). Loss of income from cows shedding Mycobacterium avium subspecies paratuberculosis prior to calving compared with cows not shedding the organism on two Minnesota dairy farms. J. Dairy Sci. 92: 4929-4936.

Ramírez, C.I.; Santillán, F.M.; Arellano, R.B.; Morales, A.F. y Tenorio, G.V. (2006). Detección de secuencias de Mycobacterium bovis a partir de ADN de moco nasal de caprinos inoculados experimentalmente. Vet. Méx. 2: 191-196.

Ramírez, N.V.; Rodríguez, B. y Fernández, J. (2011). Diagnóstico clínico e histopatológico de paratuberculosis bovina en un hato lechero en Colombia. Rev. MVZ Córdoba. 16(3): 2742-2753.

Rankin, J.D. (1961). The experimental infection of cattle with Mycobacterium johnei. J. Comp. Path. 71: 615.

Rastogi, N.; Legrand, E. y Sola, C. (2001). The micobacteria : an introduction to nomenclature and pathogenesis. Rev. Sci. Tech. 20: 21-54.

Rayja, B.S. y Singh, C.M. (1961). Studies on the pathology of Johne's disease in sheep. III. Pathologic changes in sheep with naturally occurring infections. Am. J. Vet. Res. 22: 189-203.

Rebhun, W.C. (1995). Infectious diseases of the gastrointestinal tract. En: Diseases of dairy cattle. Ed. Williams Wilkins. 1: 208-213. Baltimore, Maryland, E.E.U.U.

Reddacliff, L.A.; Vadali, A. y Whittington, R.J. (2003). The effect of decontamination protocols on the numbers of sheep strain Mycobacterium avium subsp. paratuberculosis isolates from tissues and faeces. Vet. Microbiol. 95: 271-282.

Reddy, K.P.; Sriraman, P.K.; Gopal Naidu, N.R. y Rama Rao, P. (1984). Pathology of Johne's disease in sheep. Indian Vet. J. 61: 159-164.

Reichel, M.P.; Kittelberger, R.; Penrose, M.E.; Meynell, R.M.; Cousins, D.; Ellis, T.; Mutharia, L.M.; Sugden, E.A.; Johns, A.H. y de Lisle, G.F. (1999). Comparison of serological test and faecal culture for the detection of Mycobacterium avium subsp. paratuberculosis infection in cattle and analysis of the antigens involved. Vet. Microbiol. 66: 135-150.

Renwick, A.R.; White, P.C. y Bengis, R.G. (2007). Bovine tuberculosis in southern African wildlife: a multispecies host-pathogen system. Epidemiol. Infect. 135(4): 529-540.

Retamal, P. y Abalos, P. (2004). Comparación del ensayo interferón gamma bovino con técnicas tradicionales para el diagnóstico de infección con Mycobacterium bovis en la región metropolitana de Chile. Rev. Col. Cienc. Pec. 17: 223-230.

Reynolds, J.D. y Morris, B. (1983). The evolution and involution of Peyer's patches in fetal and postnatal sheep. Eur. J. Immunol. 13: 627-635.

Riccetti, R.V.; Vasconcellos, S.A.; Ito, F.H. y Cortes, J.A. (1989). Investigacao epidemiológica sobre as zoonoses de mayor constatacao em matadouros. II Bovinos. Rev. Fac. Med. Vet. Zoot. Uni. Sao Paulo. 25: 61-68.

Richards, W.D. (1990). A new, inexpensive tests for detecting paratuberculosas in dairy herds. Ptbc. Newslett. 2: 7-8. 
Ridge, S.E. (1993). Cultivation of Mycobacterium paratuberculosis from bovine fecal samples by using elements of the Roche MB Check system. J. Clin. Microbiol. 31: 400-405.

Ridge, S.E.; Morgan, I.R.; Sockett, D.C.; Collins, M.T.; Condron, R.J.; Skilbeck, N.W. y Webber, J.J. (1991). Comparison of the Johne's absorbed EIA and the complement-fixation test for the diagnosis of Johne's disease in cattle. Aust. Vet. J. 68: 253-257.

Ridley, D.S. (1983). The histopathologycal spectrum of the mycobacterioses. En "The biology of the micobacteria. Immunological and environmental aspects". C. Ratledge y J. Stanford eds. 2: 129-171. Academic Press Inc., London.

Ritchie, J.N. (1959). Eradication of bovine tuberculosis. Infectious diseases of animals. 2: 713-739. Citado por: Pritchard, D.G. (1998). A century of bovine tuberculosis 1888-1988: Conquest and controversy. J. Comp. Patho. 99: 357-398.

Rivera, S.; Jiménez, J.F. y Deward, J. (2009). Valoración de las pruebas diagnósticas para tuberculosis bovina en un rebaño ubicado en zona de alta incidencia del estado de Zulia, Venezuela. Rev. Cient. 19: 566575.

Rivera, S. y Giménez, J.F. (2010). La tuberculosis bovina en Venezuela: patogénesis, epidemiología, respuesta inmunitaria y nuevas alternativas para el diagnóstico. Rev. Vet. 11: 1695-7504.

Robinson, M.; O`Brien, R.; Mackintosh, C. y Griffin, J.F. (2008). Differential immune responses of red Deer (cervus elaphus) following experimental challenge with Mycobacterium avium subps. paratuberculosis. Clin. Vaccine Immunol. 15: 963-969.

Roca Soler, R. (1935). Paratuberculosis en una vaca. Rev. Hig. San. Pecu. 25: 839.

Roitt, I.M.; Brostoff, J. y Male, D.K. (1991). Inmunología 2a ed. Salvat Editores, Barcelona.

Rothel, J.S.; Jones, S.L.; Corner, L.A.; Cox, J.C. y Wood, P.R. (1990) A sandwich enzyme immunoassay for bovine interferon-gamma and its use for the detection of tuberculosis in cattle. J. Aust. Vet. 67: 134-137.

Ryan, T.G.; Livingston, P.G.; Ramsey, D.S.; de Lysle, G.V.; Nugent, G.; Collins, D.M. y Buddle, B.M. (2006). Advances in understanding disease epidemiology and implications for control and eradication of tuberculosis in livestock: the experience from New Zealand. Vet. Microbiol. 112: 211-219.

SAGARPA. (2013). Situación actual de tuberculosis bovina (TBB) en la República Mexicana. http//www.sagarpa.gob.mx.ganaderia,

Sánchez, V.A.; Arráiz, R.N.; Becerra, R.L.; Faria, N.; Montero, U.M.; Oviedo, B.A.; Zambrano, N.S.A.; Boscán, O.J.; Molero, S.G. y Pino, R.D. (2009). Infección por Mycobacterium avium sub. paratuberculosis en un rebaño Criollo Limonero. Rev. Cient. 21: 555-565.

Sanna, E.; Woodall, C.J.; Watt, N.J.; Clarke, C.J.; Pittau, M.; Leoni, A. y Nieddu, A.M. (2000). In situ-PCR for the detection of Mycobacterium paratuberculosis DNA in paraffin-embedded tissues. Eur. J. Histochem. 44: 179-184.

Sanson, R.L. (1988). Tuberculosis in goats. Surveillance 15: 7-8.

Santillán, F.M.A. (2008). Detección de Mycobacterium avium subespecie paratuberculosis, por medio de PCR-anidada a partir de muestras de heces de ovinos. Vet. Méx. 39 (4).

Santos, N.; Correia-Neves, M.; Ghebremichael, S.; Kallenius, G.; Svenson, S.B. y Almeida, V. (2009). Epidemiology of Mycobacterium bovis infection in wild boar (Sus scrofa) from Portugal. J. Wildl. Dis. 45: 1048-1061. 
Saxegaard, F. (1990). Experimental infection of calves with an apparently specific goat-patogenic strain of Mycobacterium paratuberculosis. J. Comp. Path. 102: 149-156.

Schulaw, W.P; Bech-Nielsen, S.; Rings, D.M.; Getzy, D.M. y Woodruff, T.S. (1993). Serodiagnosis of paratuberculosis in sheep by use of agar gel immunodiffusion. Am. J. Vet. Res. 54: 542-550.

Schulz, L.C. y Trautwein, G. (1985). Formas especiales de inflamación. En: Kitt, T., Schulz, L.C. Tratado de anatomía patológica general. Ed. Labor.

Scott, P.R.; Clarke, C.J. y King, T.J. (1995). Serum protein concentrations in clinical cases of ovine paratuberculosis (Johne's disease). Vet. Rec. 137: 173.

Scott, H.M.; Fosgate, G.T.; Libal, M.C.; Snedd, L.W.; Erol, E.; Angulo, A.B. y Jordan, E.R. (2007). Field testing of an enhaced direct-fecal polymerase chain reaction procedure, bacterial culture of feces, and a serum enzyme-linked immunoosorbent assay for detecting Mycobacterium avium subsp. Paratuberculosis infection in adult dairy cattle. Am. J. Vet. Res. 68: 236-245.

Seaman, J.T.; Gardner, L.A. Dent, C.H. (1981). Johne's disease in sheep. Aust. Vet. J. 57: 102-103.

Seitz, S.E.; Heider, L.E.; Heuston, W.D.; Bech-Nielsen, S.; Rings, D.M. y Spangler, L. (1989). Bovine fetal infection with Mycobacterium paratuberculosas. J. Am. Vet. Med. Assoc. 194: 1423-1426.

Semret, M.; Alexander, D.C.; Turenne, C.Y.; De Hass, p.; Overduin, P.; Van Sooligen, P.; Cousins, D. y Behr, M. A. (2005). Genomic polymorphisms for Mycobacterium avium subsp. paratuberculosas diagnostics. J. Clin. Med. 43(8): 3704-3712.

Sergeant, E.S.; Marshall, D.J.; Eamens, G.J.; Kearns, C. y Whittington, R.J. (2003). Evaluation of an absorbed ELISA and an agar-gel immune-diffusion test for ovine paratuberculosis in sheep in Australia. Prev. Vet. Med. 61: 235-248.

Sevilla, A.I. (2007). Caracterización molecular detección y resistencia de Mycobacterium avium sub. paratuberculosis. Tesis de Doctorado. Universidad del país Vasco.

Sherman, D.M. (1985). Current concepts in Johne's disease. Med. Vet. Small. Anim. Clin. 80: 77-84.

Sherman, D.M.; Markham, R.J.F. y Bates, F. (1984). Agar gel immunodiffusion test for diagnosis of clinical paratuberculosis in cattle. JAVMA. 185: 179-182.

Sherman, D.M.; Gay, J.M.; Bouley, D.S. y Nelson, G.H. (1990). Comparison of the complement-fixation and agar gel immunodiffusions tests for diagnosis of subclinical bovine paratuberculosis. Am. J. Vet. Res. 51: 461465.

Shinnick, T.M. y Good, R.C. (1994). Mycobacterial taxonomy. Eur. J. Clin. Microbiol. Infect. Dis. 13: 884901.

Shirakawa, T.; Enomoto, T.; Shimazu, S. y Hopkin, J. (1997). The inverse association between tuberculin response and atopic disorder. Science. 275: 77-79.

Sigurdardóttir, Ó.G.; Press, C.M. y Evensen, O. (2001). Uptake of Mycobacterium avium subsp. paratuberculosis through the distal small intestinal mucosa in goats. An ultrastructural study. Vet. Pathol. 38: 184-189.

Simpson, C.F. (1966). Electron microscopy of arteriosclerosis in cows with Johne's disease. Am. J. Vet. Res. 27: 1197-1204. 
Singh, S.V. y Singh, N. (2000). Effect of climate on Johne's disease incidence in goat herds. Ind. J. Anim. Scien. 70: 492-493.

Singh, P.K.; Singh, S.V.; Kumar, H.; Sohal, J.S. Y Singh, A.V. (2010). Diagnostic application of IS900 PCR using blood as a source sample for the detection of Mycobacterium avium subspecies paratuberculosis in early and subclinical cases of caprine paratuberculosis. Vet. Med. Int. 2010: 748621.

Skerman, V.B.D.; McGowan, V. y Sneath, P.H.A. (1980). Approved lists of bacterial names. Int. J. Syst. Bacteriol. 30: 225-420.

Slana, I.; Paolicchi, F.; Janstova, B.; Navratilova, P. y Pávlik, I. (2008). Detection methods for Mycobacterium avium subsp. paratuberculosis in milk and milk products: a review. Vet. Med. 53: 283-306.

Smith, I. (2003). Mycobacterium tuberculosis pathogenesis and molecular determinants of virulence. Clin. Microbiol. Rev. 16: 463-96.

Smith, N.H.; Gordon, S.V.; de la Rua-Domenech, R.; Clifton-Hadley, R.S. y Hewinson, R.G. (2006). Bottlenecks and broomsticks: the molecular evolution of Mycobacterium bovis. Nat. Rev.; Microbiol. 4: 670681.

Smyth, R.H. y Christie, G.J. (1950). Some observations on Johne's disease with a further note on the examination of faecal samples. Vet. Rec. 62: 429-450.

Snider, T.G.; Olcott, B.M.; Kreeger, J.M.; Himes, M.E.; Turnquist, S.E.; Vance, T.L. y Farrar, R.G. (1992). The immunopathogenesis of rumiants paratuberculosis. Proc. III Int. Coll. PTBC. 317-325. Orlando, E.E.U.U.

Sobrino, R.; Martín-Hernando, M.P.; Vicente, J.; Aurtenetxe, O.; Garrido, J.M. y Gortázar, C. (2008). Bovine tuberculosis in a badger (Meles meles) in Spain. Vet. Rec. 163(5): 159-160.

Sockett, D.C.; Conrard, T.A.; Thomas, C.B. y Collins, M.T. (1992). Evaluation of four serological tests for bovine paratuberculosis. J. Clin. Microb. 30: 1134-1139.

Solmaz, H.; Ílhan, Z.; Akzakal, A.; Gülhan, T. y Ekín, I.H. (2009). Detection of tuberculosis by tuberculin test ad polymerase chain reaction in Van, Turkey. Turk. J. Vet. Anim. Sci. 33: 229-233.

Soto, J.P.; Krunze, J. y Leyva, S. (2002). Comparación de tres métodos diagnósticos de paratuberculosis bovina en rebaños lecheros infectados. Arch. Med. Vet. 34 (2): 265-273.

Sotohy, A.S. y Awad-Masalmeh, M. (1999). Epidemiological studies on Johne's disease in cattle using the cultura and PCR technique. Assiut Vet. Med. J. 41: 101-112.

Stabel, J.R. (1996). Production of gamma-interferon by peripheral blood mononuclear cells: an important diagnostic tool for detection of subclinical paratuberculosis. J. Vet. Diagn. Invest. 8: 345-350.

Stabel, J.R. (1998). Johne's Disease: A hidden threat. J. Dairy Sci., 81: 283-288.

Stabel, J.R. (2000). Transitions in immune responses to Mycobacterium paratuberculosis. Vet. Microbiol. 77 : 465-473.

Stabel, J.R. (2006). Host responses to Mycobacterium avium subsp. paratuberculosis: a complex arsenal. Anim. Health Res. Rev. 7: 60-70.

Stabel, J.R. y Whitlock, R.H. (2001). An evaluation of a modified interferon-gamma assay for the detection of paratuberculosis in dairy herds. Vet. Immunol. Immunopathol. 79: 69-81.

Stabel, J.R.; Goff, J.P. y Kimura, K, (2003). Effects of supplemental energy on metabolic and immune measurements in periparturient dairy cows with Johne's disease. J. Dairy Sci. 86: 3527-353. 
Stabel, J.R.; Kimura, K. y Robbe-Austerman, S. (2007). Augmentation of secreted and intracellular gamma interferon following johnin purified protein derivative sensitization of cow naturally infected with Mycobacterium avium subps. paratuberculosis. J. Vet. Diagn. Invest. 19: 43-51.

Stackebrandt, E.; Rainey, F.A. y Ward-Rainey, N.L. (1997). Proposal for a new hierarchic classification system. actinobacteria. classis. Nov. Int. J. Syst. Bacteriol. 47: 479-491.

Stamp, J.T. y Watt, J.A. (1954). Johne's disease in sheep. J. Comp. Path. 64: 26-39.

Stanford, J.L. (1983). Immunologically important constituents of micobacteria. Antigens. En: The biology of the micobacteria. Immunological and environmental aspects. Ratledge, C.; Stanford, J.L. (Eds.). Academic press. 3: 85-127. Londres, Reino Unido.

Stanley, C.; Richard, J.; Smith, J.; Glenn, M.; Barer, M.; McGowan, E. y Rees, E. (2007). Development of a new , combined rapid method using phage and PCR for detection and identification of viable Mycobacterium paratuberculosis bacteria within 48 hours. App. Env. Microbiol.. 73: 151-1857.

Stehman, S.M. (1996). Paratuberculosis in small ruminants, deer, and South American camelids. Vet. Clin. North. Am. Food Anim. Pract. 12: 441-455.

Stevenson, K.; Alvarez, J.; Bakker, D.; Biet, F.; De Juan, L.; Denham, S.; Dimarelli, Z.; Dohmann, K.; Gerlach, G.F.; Heron, L.; Kopecna, M.; May, L.; Pavlik, L.; Sharp, J.M.; Thibault, V.C.; Willemsen, P.; Zadocks, R. N. y Greig, A. (2009). Occurrence of Mycobacterium avium subspecies paratuberculosis across host species and European countries with evidence for transmission between wildlife and domestic ruminants. BMC. Microbiol. 9: 212.

Storset, A.K.; Hasvold, H.J.; Valheim, M.; Brun-Hansen, H.; Berntsen, G.; Whist, S.K.; Djonne, B.; Press, C.M.; Holstad, G. y Larsen, H.J. (2001). Subclinical paratuberculosis in goats following experimental infection. An immunological and microbiological study. Vet. Immunol. Immunopathol. 80: 271-287.

Streeter, R.N; Hoffsis, G.F.; Bech-Nielsen, S.; Shulaw, W.P. y Rings, D.M. (1995). Isolation of Mycobacterium paratuberculosis from colostrum and milk of subclinically infected cows. Am. J. Vet. Res. 56: 1322-1324.

Strommenger, B.; Stevenson, K. y Gerlach, G.F. (2001). Isolation and diagnostic of ISMav2, a novel insertion sequence-like element from Mycobacterium avium subespecie paratuberculosis. FEMS Microbiol. Lett. 196: 31-37.

Stuart, P. (1965). Vaccination against Johne's disease in cattle exposed to experimental infection. Br. Vet. J. 121: 289-318.

Sugden, E.A.; Corner, A.H.; Samagh, B.S.; Brooks, B.W.; Turcotte, C.; Nielsen, K.H.; Stewart, R.B. y Duncan, J.R. (1989). Serodiagnosis of ovine paratuberculosas, using lipoarabinomannan in an enzyme-linked immunosorbent assay. Am. J.Vet. Res. 50: 850-854.

Surujballi, O.; Lutze-Wallace, C.; Turcotte, C.; Savic, M.; Stevenson, D.; Romanowska, A.; Monagle, W.; Berlie-Surujballi, G. y Tangorra, E. (2009). Sensitive diagnosis of bovine tuberculosis in a farmed cervid herd with use of an MPB70 protein fluorescence polarization assay. The Canadian Journal of Veterinarian Research. 73: 161-164.

Sweeney, R.W. (1996). Transmission of paratuberculosis. Vet. Clin. North Am. Food Anim. Pract. 12: 305312.

Sweeney, R.W.; Whitlock, R.H. y Rosenberger, A.E. (1992). Mycobacterium paratuberculosis isolated from fetuses of infected cows not manifesting signs of the disease. Am. J.Vet. Res. 53: 477-480. 
Sweeney, R.W.; Whitlock, R.H.; Buckley, C.L.; Spencer, P.A.; Rosenberger, A.E. y Hutchinson, L.J. (1995). Diagnosis of paratuberculosis in dairy cattle, using enzyme-liked immunosorbent assay for detection of antibodies against Mycobacterium paratuberculosis in milk. Am. J. Vet. Res. 55: 905.

Talbot, E.A.; Williams, D.L. y Frothingham, R. (1997). PCR identification of M. bovis BCG. J. Clin. Méx. 35: 566-569.

Taylor, A.W. (1951). Varieties of Mycobacterium johnei isolated from sheep. J. Path. Bact. 63: 333-336.

Tejedor, M. (2002). Estudio epidemiológico de la paratuberculosis ovina en la provincia de Segovia. En línea consultado: 27 de junio del 2011. www.ucm.es/BUCM/tesis/19911996/D/AD2002201.pdf.

Temple, R.M.; Muscoplat, C.C.; Thoen, C.O.; Himes, E.M. y Johnson, D.W. (1979). Observations on diagnosis tests for paratuberculosis in a deer herd. J. Am. Vet. Med. Assoc. 175: 914-915.

Tessema, M.Z.; Koets, A.P.; Rutten, V.P. Y Gruys, E. (2001). How does Mycobacterium avium subsp. paratuberculosis resist intracellular degradation? Vet. Q. 23: 153-162.

Thoen, C.O.; Jarnagin, J.L. y Richards, W.D. (1975). Isolation and identification of micobacteria from porcine tissue: a three-year summary. Am. J. Vet. Res. 36: 1383-1386.

Thoen, C.O.; Hall, M.R.; Tannis, A.; Petersburg, S. y Harrington, R. (1983). Detection of mycobacterial antibodies in sera of cattle experimentally exposed to Mycobacterium bovis by one of a modified enzyme linked immunosorbent assay. Proc. XXVI Ann. Assn. Vet. Lab. Diag. 25-28.

Thoen, C.O.; Temple, R.M.S, y Johnson, L.W. (1988). An evaluation of certain diagnostic tests for detecting some immune responses in llamas exposed to Mycobacterium bovis. Proceedings of the $92^{\text {nd }}$ Annual Meeting of the United States Animal Health Association, Little Rock, Arkansas. 525-533.

Thomas, G.W. (1983). Paratuberculosis in a large goat herd. Vet. Rec. 113: 464-466.

Thorel, M.F. (1984). La paratuberculose caprine. Mise au point et synthese. En: INRA editor. Les maladies de la chavre, 28, pp. 519-527. Maison Alfort, France.

Thorel, M.F.; Krichevsky, M. y Levy-Frebault, V.V. (1990). Numerical taxonomy of micobactina-dependent micobacteria, emended description of Mycobacterium avium subsp. paratuberculosis subsp. nov. and Mycobacterium avium subsp. silvaticum. Int. J. Syst. Bacteriol. 40: 254-260.

Thorel, M.F. y Moutou, F. (1994). Tuberculose et animaux sauvages. Point Vét. 26: 27-34.

Thorensen, O.F.; Falk, K. y Evenson, O. (1994). Comparison of immunohistochemistry, acid-fast staining, and cultivation for detection of Mycobacterium paratuberculosis in goats. J. Vet. Diagn. Invest. 6: 195-199.

Thrusfield, M.; Ortega, C.; De Blas, L.; Noordhuizen, J.P. y Frankena, K. (2001). WIN ESPISCOPE 2.0: improved epidemiological software for veterinary medicine. Vet. Rec. 148: 567-572.

Tiwari, A.; John, A.; Leeuwen, V.; Shawn, L.; McKenna, G.; Keefe, G. y Barkema, H. (2006).Johne's disease in Canada part I: clinical symptoms, pathophysiology, diagnosis and prevalence in dairy herds. J. Can Vet. 47: 874-882.

Tizard, I. (2002). Inmunología veterinaria. $6^{a}$ ed. p 371-379. Ed. Mc Graw-Hill Interamericana. España.

Tolson, J.W. y Jervois, K.Y.M. (1990). A study to determine the monitoring requirements for the Brucellosis and Tuberculosis Campaign in Australia after 1992. Citado por: Corner, L.A., Wood, P.R., Rothel, J.S. (1991). Reply to the correspondence: Efficiency of inspection procedures for the detection of tuberculous lesions in cattle. Australian Veterinary Journal. 68 (6): 218-219. 
Torres, P. y Kantor, I.N. (1996). Taller: Bases para un sistema de información y vigilancia epidemiológica de la tuberculosis bovina en la República Argentina. Informe final SENASA, INPPAZ/OPS/OMS. 3-8.

Torres, P. (2010). Vigilancia epidemiológica: importancia de la detección en faena de la tuberculosis bovina. SENASA. 1-7.

Tripathi, B.N.; Periasamy, S.; Paliwal, O.P. y Singh, N. (2006). Comparison of IS900 tissue PCR, bacterial culture, johnin and serological test for diagnosis of naturally occurring paratuberculosis in goats. Vet. Microbiol. 116: 129-137.

Tweddle, N.E. y Livingstone, P. (1994). Bovine tuberculosis control and eradication programs in Australia and New Zealand. Vet. Microbiol. 40:23-39.

Twort, F.W. e Ingram, G.L.Y. (1911). A method for isolating and cultivating the Mycobacterium enteriditis chronicae pseudotuberculosae bovis, Johne, and some experiments on the preparation of a diagnostic vaccine for pseudotuberculous enteritis of bovines. Roy. Soc. Proc. B. 84: 517-542.

Underwood, S.C. y Carfagnini, J.C. (2005). Comparación de dos criterios para la interpretación de la prueba tuberculínica cervical comparativa en caprinos. Rev. Arg. Prod. Anim. 25: 199-205.

Valentin-Weingand, P. y Goethe, R. (1999). Pathogenesis of Mycobacterium avium subspecies paratuberculosis infection in ruminants: still more questions than answers. Microbes and Infect. 1: 11211127.

Valheim, M.; Storset, A.K.; Aleksandersen, M.; Brun-Hansen, H. y Press, C.M. (2002). Lesions in subclinical paratuberculosis of goats are associated with persistent gut-associated lymphoid tissue. J. Comp. Pathol. 127: 194-202.

Vallee, H. y Rinjard, P. (1926). Etudes sur Iéntérite paratuberculeuse des bovides. Rev. Gen. Med. Vet. 34: 19.

Van der Giessen, J.W.; Haring, R.M. y Van der Zeijst, B.A. (1994). Comparison of the 23S ribosomal RNA genes and the spacer región between the 16S and 23S rRNA genes of the closely related Mycobacterium avium and Mycobacterium oaratuberculosis and the fast-growing Mycobacterium phlei. Microbiology. 14: 1103-1108.

Vaneechoutte, M.; de Beenhouwer, H.; Claeys, G.; Verschraegen, G.; de Rouck, A.; Paepe, N.; Elaichouni, A. y Portaels, F. (1993). Identification of Mycobacterium species by using amplified ribosomal DNA restriction analysis. J. Clin. Microbiol. 31: 2061-2065.

Vanham, G.; Toossi, Z.; Hirsch, C.S.; Wallis, R.S.; Schwander, S.K.; Rich, E.A. y Ellner, J.J. (1997). Examining a paradox in the pathogenesis of human pulmonary tuberculosis: immune activation and suppression/anergy. Tubercle Lung. Dis. 78 (3-4): 145-158.

Van Kruningen, H.J.; Ruiz, B. y Gumprecht, L. (1991). Experimental disease in young chickens induced by a Mycobacterium paratuberculosis isolated from a patient with Crohn's disease. Can. J. Vet. Res. 95: 199202.

Van Schaik, G.; Kalis, C.H.; Benedictus, G.; Dijkhuizen, A.A. y Huine, R.B. (1996). Cost benefit analysis of vaccination against paratuberculosis in dairy cattle. Vet. Rec. 139: 624-627.

Van Schaik, G.; Stehman, S.M.; Shukken, Y.H.; Rossiter, C.R.; Shin, S.J. (2003). Pooled fecal culture sampling for Mycobacterium avium subsp. paratuberculosis at different herd sizes and prevalence. J. Vet. Diagn. Invest. 15: 233-241.

Van Soolingen, D.; De Haas, P.E.W.; Haagsma, J.; Eger, T.; Hermans, P.W.M.; Ritacco, V.; Alito, A. y Van Embden, J.A.N. (1994). Use of various genetic markers in differentiation of Mycobacterium bovis strains 
from animals and humans and for studying epidemiology of bovine tuberculosis. Journal of Clinical Microbiology. 32: 2425-2433.

Van Soolingen, D.; Bauer, J.; Ritacco, V.; Liao, S.C.; Pávlik, I.; Vincent, V.; Rastogi, N.; Gori, A.; Bodmer, T.; Garzelli, C. y García, M.J. (1998). IS1245 restriction fragment length polymorphism typing of Mycobacterium avium isolates: proposal for standardization. J. Clin. Microbiol. 36: 3051-3054.

Vannuffel, P.; Gilot, P.; Limbourg, B.; Naerhuyzen, B.; Dieterich, C.; Coene, M.; Machtelinckx, L. y Cocito, C. (1994). Development of species-specific anzyme-linked immunosorbent assay for diagnosis of Johne's disease in cattle. J. Clin. Microbiol. 32: 1211-1216.

Vary, P.H.; Andersen, P.R.; Green, E.; Hermon-Taylor, J. y McFadden, J.J. (1990). Use of highly specific DNA probes and the polymerase chain reaction to detect Mycobacterium paratuberculosis in Johne's disease. J. Clin. Microbiol. 28: 933-937.

Velarde, F.S.; Morales, L.A.; Garzón, T.J.; Álvarez, O.G.; Aviles, G.M.; Mendoza, D.L.; Félix, A.B.; Robles, C.T.; Velarde, F.J. y Berrelleza, A.T. (2007). Detección mediante PCR de organismos del complejo $M$. tuberculosis en muestras de exudado en ganado bovino. J. Clin. Med. 11-16.

Vestal, A.L. (1975). Procedures for the isolation and identification of mycobacteria. Center for Disease Control, PHS, Atlanta.

Vicente, J.; Hofle, U.; Garrido, J.M.; Fernández de Mera, I.G.; Juste, R. y Gortázar, C. (2006). Wild boar and red deer display high prevalences of tuberculosis-like lesions in Spain. Vet. Res. 37: 107-119.

Villanueva, V. y de Aluja, A. (1998). Estado actual de algunas plantas de sacrificio de animales para consumo humano en México. Vet. Méx. 29 (3): 273- 278.

Vitale, F. (1998). Detection of Mycobacterium tuberculosis Complex in Cattle by PCR Using Milk, Lymph Node Aspirates and Nasal Swabs. J. Clin. Microbiol. 36: 1050-1055.

Vuorinem, P.A.; Uvento, M.R. y Hallstron, O. (1995). Direct detection M. tuberculosis complex respiratory specimens by Gene-Probe amplified M. tuberculosis direct test and roche amplicor M. tuberculosis test. J. Clin. Microbiol. 33 (7): 1856-1859.

Wards, B.J.; Collins, D.M. y Liste, G.W. (1995). Detection of Mycobacterium bovis in tissues by polymerase chain reaction. Vet. Microbiol. 43: 227-240.

Waters, W.; Palmer, M.; Whipple, D.; Carlson, M. y Nonnecke, B. (2003). Diagnostic implication of antigeninduced gamma interferon, nitric oxide, and tumor necrosis factr alpha production by peripheral blood mononuclear cells from Mycobacterium bovis- infected cattle. Clin. Diagn. Lab. Immun. 10: 960- 66.

Wayne, L.G. y Kubica, G.P. (1986). Family Micobacteriaceae Chester, 1987. En: "Bergey" manual of systematic bacteriology. Sneath, P.H.A.; Mair, N.S.; Sharpe, M.E.; Holt, J.G. (Eds.). Willians \& Wilkins Vol. 2: 1436-1457. Baltimore, E.E.U.U.

Weber, A.; Gurke, R.; Bauer, K. y Schreyer, K. (1992). Bacterial studies on the occurrence of Mycobacterium paratuberculosis in fecal samples of zoo ruminants. Berl. Munch. Tierarztl. Wochenschr. 105: 161-164.

Wells, S.J.: Whitlock, R.H.; Linderman, C.J. y Fyock, T. (2002). Evaluation of bacteriologic culture of pooled fecal samples for detection of Mycobacterium paratuberculosis. Am. J. Vet. Res. 63: 1207-1211.

Wells, S.J.; Godden, S.M.; Lindeman, C.J. y Collins, J.E. (2003). Evaluation of bacteriologic culture of individual and poled fecal samples for detection of Mycobacterium paratuberculosis in dairy cattle herds. J. Am. Vet. Med. Assoc. 223: 1022-1025. 
Wells, S.J.; Michael, T.; Collins, K.S.; Kay, S.; Faaberg, C.; Wees, C.; Tavornpanich, S.; Petrini, R.; James, E.; Collins, C.N. y Withlock, H. (2006). Evaluation of a rapid fecal PCR test for detection of Mycobacterium avium subsp. paratuberculosis in dairy cattle. Clin. Vacc. Immunol. 13(10): 1125-1130.

Whipple, D.L. y Palmer, M.V. (2000). Reemergence of Tuberculosis in animals in the United States. En: Emerging Diseases of Animals. Ed. C. Brown y C. Bolin. ASM Press, Washington, D.C.

Whipple, D.L.; Bolin, C.A.; Davis, A.J.; Jarnagin, J.L.; Johnson, D.C.; Nabors, R.S.; Payeur, J.B.; Saari, D.A.; Wilson, A.J. y Wolf, M.M. (1995). Comparison of the sensitivity of the caudal fold skin test and a commercial gamma-interferon assay for diagnosis of bovine tuberculosis. Am. J. Vet Res. 56 (4): 415-419..

Whipple, D.L.; Bolin, C.A. y Miller, J.M. (1996). Distribution of lesions in cattle infected with Mycobacterium bovis. J. Vet. Diagn. Invest. 8 (3): 351-354.

Whist, S.K.; Storset, A.K. y Larsen, H.J.S. (2000). The use of interleukin-2 receptor expression as an marker of cell-immunity in goats experimentally infected with Mycobacterium avium ssp. paratuberculosis. Vet. Immunol. Immunopathol. 73: 207-218.

Whitlock, R.H. (1998). Johne's disease (Paratuberculosis): diagnosis tests for individual animal and the herd. En: $A N E M B E$ editor. Pp. 69-72. Stiges.

Whitlock, R.H. (1999). Enfermedad de Johne (paratuberculosis): Test diagnósticos individuales y a nivel de rebaño. ANEMBE. Boletín informativo. 17: 24-26.

Whitlock, R.H. y Buergelt, C. (1996). Preclinical and clinical manifestations of paratuberculosis (including pathology). Vet. Clin. North. Am. Food. Anim. Pract. 12: 345-356.

Whitlock, R.H.; Wells, S.J.; Sweney, R.W. y Van Tiem, J. (2000) ELISA and faecal culture for sensitive and economic detection of Mycobacterium avium subsp. paratuberculosis infection in flocks of sheep. J. Clin. Anim. Pract. 12, 345-356.

Whittington, R.H.; Reddacliff, L.A.; Marsh, I.B. y Saunders, V. (1999b). Detection of Mycobacterium avium subps. paratuberculosis in formalin-fixed paraffin-embedded intestinal tissue by IS900 polymerase chain reaction. Aust. Vet. J. 77: 392-397.

Whittington, R.J.; Fell, S.: Walker, D.; McAllister, S.; Marsh, I.; Sergeant, E.; Taragel, C.A.; Marshall, D.J. y Links, I.J. (2000). Use of pooled fecal culture for sensitive and economic detection of mycobacterium avium subsp. Paratuberculosis infection in flocks of sheep. J. Clin. Microbiol. 38: 2550-2556.

Whittington, R.J.; Lloyd, J.B. y Reddacliff, L.A. (2001a). Recovery of Mycobacterium avium subsp. Paratuberculosis from nematode larvae cultures from the faeces of sheep with Johne's disease. Vet. Microbiol. 81: 273-279.

Whittington, R.J.; Marsh, I.B. y Whitlock, R.H. (2001b). Typing of IS1311 polymorphisms confirms that bison (Bison bison) with Paratuberculosis in Montana are infected with a strain of Mycobacterium avium subsp. Paratuberculosis distinct from that occurring in cattle and other domesticated livestock. Mol. Cell. Probes. 15: 139-145.

Whittington, R.J.; Taragel, C.A.; Ottaway, S.; Marsh, I.; Seaman, J. y Fridriksdottir, V. (2001c). Molecular epidemiological confirmation and circumstances of occurrence of sheep (S) strains of Mycobacterium avium subsp. paratuberculosis in cases of paratuberculosis in cattle in Australia and sheep and cattle in Iceland. Vet. Microbiol. 79: 311-322.

WHO. (1994). Report of the WHO group on zoonotic tuberculosis (Mycobacterium bovis) with the participation of FAO: World Health Organization. Veter. Public. Health, 1-43. 
WHO. (2009). Global tuberculosis control. WHO/HTM/TB/2009. 411 Geneve: World Health Organization 2009.

Wilesmith, J.W. (1991). Epidemiological methods for investigating wild animal reservoirs of animal disease. Rev. sci. tech. Off. int. Epiz. 10: 205-214.

Williams, G.T. y Williams, W.J. (1983). Granulomatous inflammation- a review. J. Clin. Pathol. 36: 723733.

Wobeser, Gary. (2009). Bovine tuberculosis in Canadian wildlife: An updated history. J. Can. Vet. 50: 11691176.

Wolinsky, E. (1980). Mycobacterium. En: Tratado de Microbiología. (Davis, B.D.; Dulbecco, R.; Eisen, H.N.; Ginsberg, H.S.; Wood, W.B. y McCarthy, M., eds.) pp. 867-892. Salvat Editores, S.A. Barcelona.

Wood, P.R.; Kopsidas, K.; Milner, A.R.; Hill, J.; Gill, I.; Webb, R.; Mack, W.N. y Coates, K. (1989). The development of an in vitro cellular assay for Johne's disease in cattle. En: Johne's disease: current trends inresearch, diagnosis and management. Milner, A.R. y Wood, P.R. (Eds.) CSIRO: 164-167. Melbourne, Australia.

Wood, P.R.; Corner, L.A. y Plackett, P. (1990). Development of a simple, rapid in vitro cellular assay for bovine tuberculosis based on the production of $\gamma$ interferon. Res. Vet. Sci. 49: 46-49.

Wood, P.R.; Corner, L.A.; Rothel, J.S.; Baldock, C.; Jones, S.L.; Cousins, D.B.; McCormick, B.S.; Francis, B.R.; Creeper, J. y Tweddle, N.E. (1991). Field comparison of the interferon-gamma assay and the intradermal tuberculin test for the diagnosis of bovine tuberculosis. Aust. Vet. J. 68: 286-290.

Yajko, P.D.M.; Hadley, W.K.; Sanders, C.A.; Nassos, P.S.; Madej, J.J. y Hopewell, P.C. (1995). Clinical utility of a comercial test based on the polimerasa chain reaction for detecting M. tuberculosis in respiratory specimens. Am. J. Respir. Crit. Care. Med. 151 (6): 1872-1877.

Yakes, B.; Lipert, J. Bannantine, P. y Porter, D. (2008). Detection of Mycobacterium avium subsp. paratuberculosis by a sonicate immunoassay based on surface-enhanced raman scattering. Clin. Vacc. Immunol. 15(2): 227-234.

Yañez, L.; Jaimes, L. y Olivera, H. (1996). Mycobacterium bovis en salud pública: técnicas moleculares en el diagnóstico de la tuberculosis. Comité. 9

Yokomizo, Y.; Yugi, H. y Merkal, R.S. (1983). A methos of avoiding false positive reactions in an enzymelinked immunosorbent assay (ELISA) for the diagnosis of bovine paratuberculosis. Jap. J. Vet. Sci. 47:111119.

Yokomizo, Y.; kishima, M.; Mori, Y. y Nishimori, K. (1991). Evaluation of enzyme-linked immunosorbent Assay in comparison with complement fixation test for the diagnosis of subclinical paratuberculosis in cattle. J. Vet.Med. Sci. 53: 577-584.

Zapata, R.; Rodas, G. y Maldonado, E. (2008). Paratuberculosis bovina: situación real de la enfermedad en la ganadería colombiana. Rev. Colom. Cienc. Pecua. 21(3).

Zendejas, M.H.; Milián S.F.; García, C.L.; Cruz, B.G.; Anaya, E.A.M. y Huitrón, M.G. (2007). La utilidad de los sistemas de información geográfica en la predicción de la distribución regional de la tuberculosis bovina en Jalisco, México. IMS éx. 45(3): 279-287.

Zimmer, K.; Dräger, K.G.; Klawonn, W. y Hess, R.G. (1999). Contribution to the diagnosis of Johne's disease in cattle. Comparative studies on the validity of Ziehl-Neelsen staing, faecal culture and a commercially available DNA-probe test in detecting Mycobacterium paratuberculosis in faeces from cattle. $J$. Vet. Med. B. 46: 137-140. 
